Sociabilidades em conjuntos habitacionais produzidos pelo Estado: o caso da COHAB Cidade Tiradentes

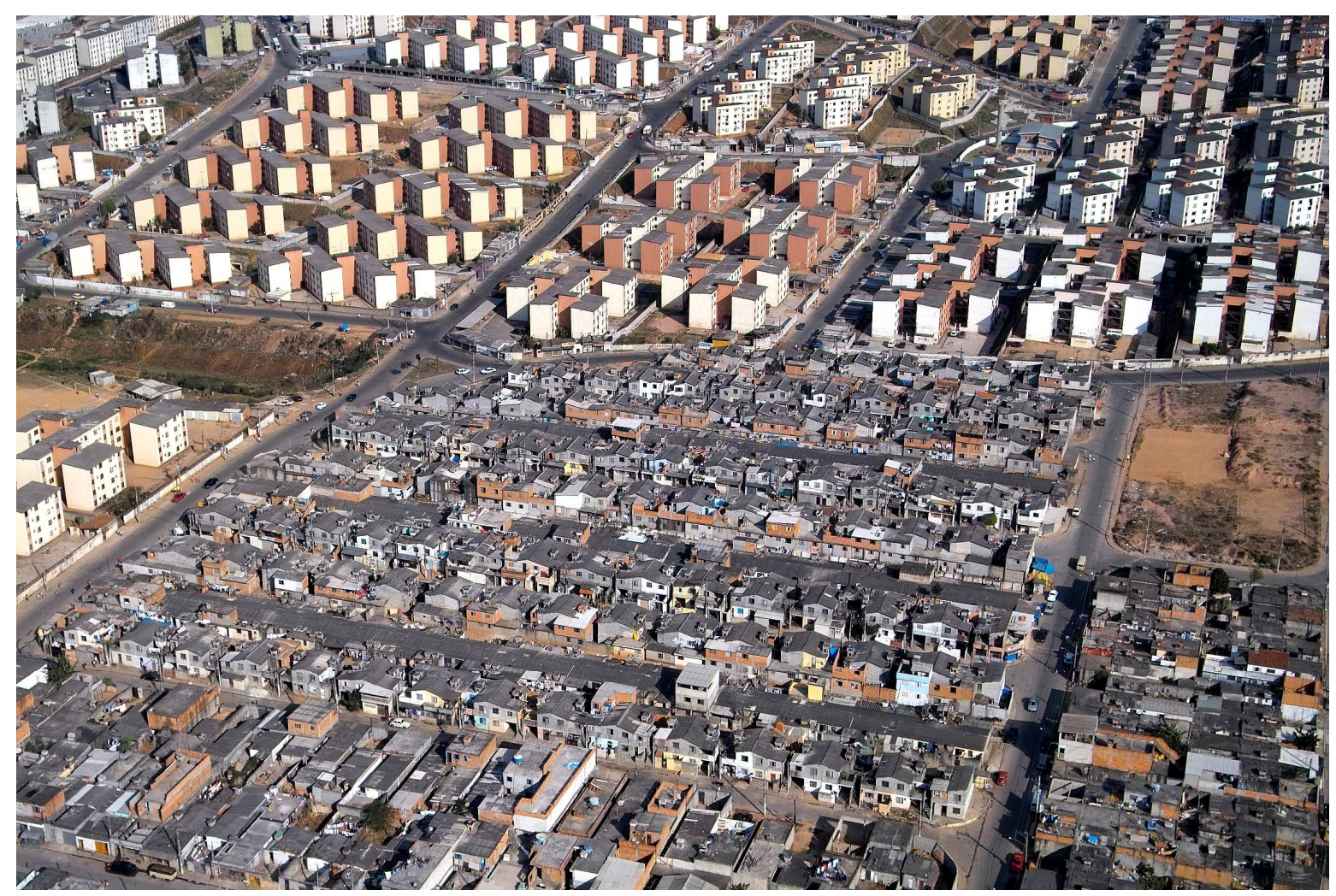

São Paulo 
Sociabilidades em conjuntos habitacionais produzidos pelo Estado: o caso da COHAB Cidade Tiradentes

Dissertação apresentada ao Programa de Pós-Graduação em Arquitetura e Urbanismo da Escola de Engenharia de São Carlos para obtenção do grau de mestre.

Orientadora:

Profa. Dra. Cibele Saliba Rizek 
Para meus pais, Dirce e Evaldo 
AUTORIZO A REPRODUÇÃO E DIVULGAÇÃO TOTAL OU PARCIAL DESTE TRABALHO, POR QUALQUER MEIO CONVENCIONAL OU ELETRÔNICO, PARA FINS DE ESTUDO E PESQUISA, DESDE QUE CITADA A FONTE.

Ficha catalográfica preparada pela Seção de Tratamento da Informação do Serviço de Biblioteca - EESC/USP

L414s Lavos, Ana Paula Alves de

Sociabilidades em conjuntos habitacionais produzidos pelo Estado : o caso da CoHAB Cidade Tiradentes / Ana Paula Alves de Lavos; orientadora Cibele Saliba Rizek. -- São Carlos, 2009.

Dissertação (Mestrado-Programa de Pós-Graduação e Área de Concentração em Arquitetura e Urbanismo -- Escola de Engenharia de São Carlos da Universidade de São Paulo, 2009 .

1. Espaço público. 2. Espaço privado. 3. Espaço coletivo. 4. Conjunto habitacional. 5. Sociabilidade. I. Título.

Foto da Capa: Jorge Hirata. Pesquisa Mobilidades urbanas e trajetórias sociais: trabalho, moradia e mobilidade cotidiana.Coordenação: Vera Telles e Robert Cabanes. 
FOLHA DE JULGAMENTO

Candidata: Bacharel ANA PAULA ALVES DE LAVOS

Dissertação defendida e julgada em 30/03/2009 perante a Comissão Julgadora:

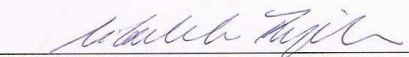

Prof. Associada CIBELE SALIBA RIZEK (Orientadora)

Appourda

(Escola de Engenharia de/São Carlos/USP)
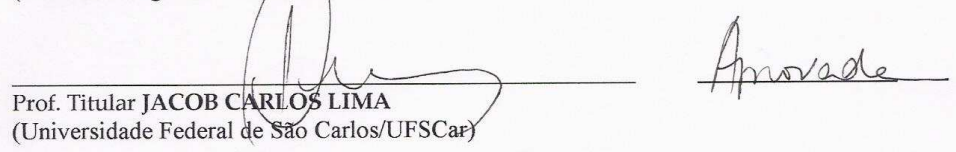

(Universidade Federal de Săo Carlos/UFSCał)

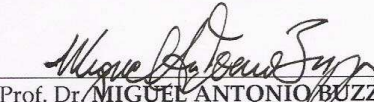

Prof. Dr MIIGUE ANTONIO B ZZZAR

(Escola de Engenharia de São Carlos/USP)

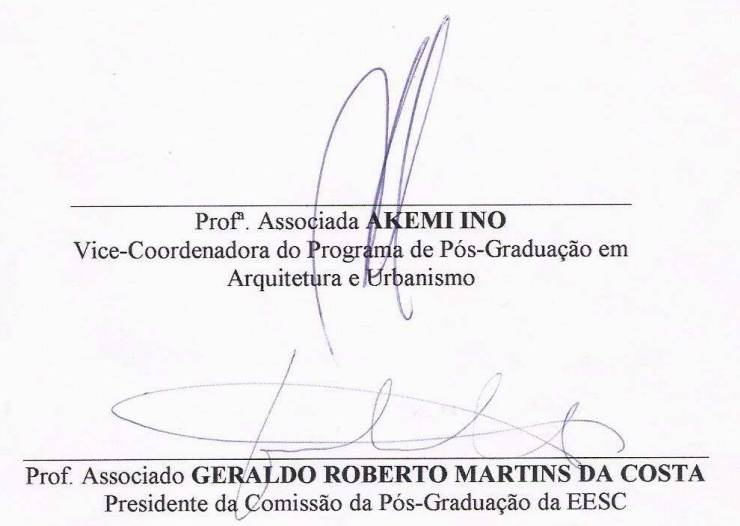




\section{Agradecimentos}

Agradeço aos meus pais, Dirce e Evaldo, por todo o apoio durante os últimos desafiadores anos, e pelo carinho e confiança ao longo de toda a caminhada.

Aos meus Aurélio e Wagner, e à minha cunhada Fabiana pelo companheirismo. Agradeço aos meus sobrinhos Rafael e Miguel pelos momentos de descontração e alegria.

Agradeço aos meus tios, Áurea de Souza Bueno e Osmar de Souza Bueno, por me acolherem tantas vezes em sua casa quando das minhas constantes viagens a São Carlos. A meu primo Ricardo de Souza Bueno, agradeço pelas freqüentes caronas.

Intelectualmente há referências fundamentais na consecução deste trabalho. Vera Telles foi inspiradora brilhante nos anos de formação e grande apoiadora na tarefa da pesquisa. Robert Cabanes com sua incansável disposição para o campo e para a reflexão orientou muitos caminhos da pesquisa e fez observações importantes em muitos momentos. Agradeço a Vera Telles e a Robert Cabanes, ademais, pelo generoso empréstimo das fotos aéreas de Cidade Tiradentes, material da pesquisa "Mobilidades urbanas e trajetórias sociais: trabalho, moradia e mobilidade cotidiana", em que foram coordenadores.

Agradeço também à Selma Venco, que dispensou momentos de atenção acompanhando com seriedade, sem ter a obrigação, a etapa final deste trabalho.

Agradeço aos professores João Marcos de A. Lopes e Jacob Lima pelas importantes observações apontadas no decisivo momento da qualificação.

A gratidão à presença de Cibele Saliba Rizek na orientação deste trabalho é imensa. Cibele dispensou confiança, apoio e os estímulos necessários em todos os momentos do processo. Sua dedicação em cada uma das etapas trouxe a suavidade de sua presença afetiva consolidando sua postura política crítica fundamentada, referência 
fundamental nas reflexões tecidas. Sua dedicação na etapa final trouxe a tranqüilidade necessária à finalização desta dissertação.

Os amigos, em muitos momentos da vida, são figuras que nos fazem mais fortes e atentos. Geórgia Christ Sarris foi precisa e doce em sua intervenção e a agradeço muito. Stela Ferreira é um modelo para a conduta em campo, assim como Eliane Alves. Debates em vários momentos com Nilde Balcão, José César, Daniel Hirata, Gabriel Feltran, Daniel de Lucca e Isabel Georges ajudaram a desenvolver algumas idéias.

Tatiana Schreiner foi a amiga presente e apoiadora em todos os momentos.

Bia Barros, Flávia Lima, Cristiane Hirata e Aramis Silva são figuras cujas conversas reflexivas e despretensiosas acompanharam todo o percurso. Alan Pereira, Bianca Briguglio e Denise Chiccoli muito ouviram sobre a famosa "dissertação" e sempre tiveram uma palavra de apoio. Nossas conversas são, sempre, muito agradáveis e estimulantes. Maria Helena Castro Lima teve um papel importante animando a realização de atividades físicas.

Agradeço carinhosamente a Ricardo Alves da Silva, que vem acompanhando o desdobramento deste trabalho com sua postura reflexiva e sua dedicação zelosa. Sua companhia é querida e grata.

Agradeço a Lais Schalch pela versão do resumo para o inglês.

Sem o apoio e a confiança de Juan Sanches e Lucas Cordeiro, da Sert, a finalização deste trabalho estaria comprometida.

Agradeço a Gilberto da COHAB e ao Nivaldo da biblioteca da EESC pela realização de importante trabalho de apoio a esta pesquisa.

Do mesmo modo agradeço ao CNPQ pela bolsa de pesquisa concedida entre março de 2007 e outubro do mesmo ano.

Agradeço a Thaisa Pfaff que diagramou a versão final do texto. 
A cada pessoa com quem conversei em Cidade Tiradentes, e que aqui assumem o talvez desconfortável papel de objeto da investigação, meu muito obrigado e a lembrança de que papéis são em tudo situacionais. 


\title{
Sociabilidades em conjuntos habitacionais produzidos pelo Estado: o caso da COHAB Cidade Tiradentes
}

\author{
RESUMO
}

Este trabalho tem como objetivo analisar as relações de sociabilidade entre os moradores de um prédio no Conjunto Habitacional Cidade Tiradentes produzido pela Companhia Metropolitana de Habitação de São Paulo - COHAB -SP localizado na zona leste de São Paulo.

O trabalho apresenta um breve histórico da ocupação urbana da cidade de São Paulo, mostrando alguns dos fundamentos do processo de segregação. Discute-se o papel do Estado como elemento que, ao invés de coibir, acaba se constituindo como produtor de segregação sócio-espacial.

Por meio de alguns indicadores sociais, ilustra-se a situação de segregação sócio-espacial de Cidade Tiradentes. Os aspectos qualitativos desta segregação são manifestados nas falas dos moradores entrevistados.

É apresentado o conceito de espaço coletivo, espaço real e simbólico situado entre o espaço público e o espaço privado. Neste espaço a sociabilidade dos moradores se coloca em cena, em situações de construções de solidariedades e visões comuns ou de distinções. Por meio da análise destas relações, organizadas no relato de vida dos moradores, observa-se a produção e a dinâmica do espaço coletivo. 


\title{
Sociability in housing Estate: the case of COHAB Cidade Tiradentes
}

\begin{abstract}
This paper has as its aim to analyze the sociability of the residents of a building in Conjunto Habitacional Tiradentes (Tiradentes Housing Estate) built by the Companhia Metropolitana de Habitação de São Paulo (São Paulo's Metropolitan Housing Company) - COHAB - SP located in the eastern area of São Paulo.
\end{abstract}

This dissertation presents a brief history of the urban occupation of the city of São Paulo, analyzing the urban segregation process. The State's role as an urban segregator element instead of curbing this problem is discussed.

The social-spatial segregation situation in Cidade Tiradentes is illustrated through some social indicators. The qualitative aspects of this segregation are clarified in the speech of the interviewed dwellers.

In this dissertation it is discussed the notion of collective, real and symbolic space situated between the public and the private space. In the collective space the dweller's sociability is at spot, in situations of solidarities construction and of common, different or distinction views. By the analysis of these relations, organized in the dwellers' life report, one can observe the collective space construction. 
$\underline{\text { ÍNDICE }}$

INTRODUĊ̃̃O

CAPÍTULO 1 - ASPECTOS HISTÓRICOS DA CONFIGURAĊ̃̃O

URBANA DE SÃO PAULO

Genealogia da Segregação em SÃo Paulo

A QUESTÃo hABITACIONAL E O SURGIMENTO DA VALORIZAÇÃo DA CASA PRÓPRIA NOS MEIOS POPULARES

AUto-EMPREendimento da CASA PRóPRIA e PERIFERIZAÇÃo

40

CAPÍTULO II - UM CAPÍTULO DA POLÍTICA HABITACIONAL EM SÃO PAULO: O DISTRITO DE CIDADE TIRADENTES

$\begin{array}{ll}\text { ATUAÇÃO DA COHAB-SP } & 48\end{array}$

EXPANSÃo URbana e Conjunto Habitacional SANTA Etelvina 53

$\begin{array}{ll}\text { Produção Estatal de Habitação em Cidade Tiradentes } & 63\end{array}$

$\begin{array}{ll}\text { ALGUNS INDICADORES SOCIAIS } & 72\end{array}$

Equipamentos Públicos em Cidade tiradentes - UMA história de conquista dos MORADORES

CAPÍTULO III - O ESPACO COLETIVO NUMA EXPERIÊNCIA ETNOGRÁFICA EM UM PRÉDIO DA COHAB CIDADE TIRADENTES EM SÃO PAULO 81

$\begin{array}{lr}\text { INTRODUÇãO METODOLÓGICA } & 84\end{array}$

Espaço Coletivo - Entre o Espaço Privado e o Espaço Público 88

A EXPERIÊNCIA DE CAMPO E A GÊNESE DE UM CONCEITO: O ESPAÇO COLETIVO 91

CONDOMÍNIOS NA COHAB: GESTÃO OU DISCIPLINAMENTO $\quad 94$

MEDIAÇÕES PARA O ESPAÇO COLETIVO: ENTRE O PÚBLICO E O PRIVADO 99 
BREVES CONSIDERAÇÕES SOBRE O FENÔMENO DA VIOLÊNCIA EM CIDADE TIRADENTES 

A sociabilidade está presente nas relações cotidianas dos sujeitos sociais. A sociabilidade é produto de suas visões de mundo, de sua vivência no espaço público e da formação de sua afetividade no espaço privado.

Por meio da sociabilidade são firmados pontos de vista a respeito do outro que orientam condutas. Estes pontos de vista se relativizam a partir da reflexão sobre novas informações. Estes pontos de vista orientam aproximações e distanciamentos de grupos e de condutas coletivas. Estas condutas são vivenciadas nos espaços socialmente produzidos, mas, ao mesmo tempo, são produtoras destes espaços.

Analisar a produção de moradia de interesse social é observar dinâmicas espaciais e pôr luz em formas de entendimento acerca do direito à moradia e das estratégias das quais o Estado e os diversos governos que nele atuam lançam mão para sua realização. A perspectiva deste trabalho, por resultar de um percurso de formação acadêmica da autora, é crítica. Ao mesmo tempo, neste trabalho está o desejo de que colocar luz em uma situação em que decisões foram tomadas talvez sem considerar todos os aspectos relevantes promova reflexão, relativize pontos de vista e contribua para a ampliação da ética e da estética nas consciências daqueles que têm o papel de promover políticas públicas.

O objetivo deste trabalho é analisar a produção do espaço social e suas reverberações nas relações de sociabilidade. O tema é amplo e demandou um recorte, a saber, a produção do espaço pelo Estado num caso específico (o conjunto Cidade Tiradentes, produzido pela COHAB-SP entre 1970 e 1990) e seus desdobramentos do ponto de vista das relações de sociabilidade. As relações de sociabilidade foram recortadas dentro de um único edifício no conjunto habitacional, dados os limites próprios a uma pesquisa de mestrado. 
O Estado, instituição que envolve saberes técnicos e poderes políticos no uso do Fundo Público, está presente em todos os momentos da produção do espaço social. É por meio de legislações e regulamentos que o espaço é caracterizado, e as relações entre os cidadãos e o espaço é mediada, por meio de normas para o uso e ocupação do solo, que organizam o espaço em vias, glebas, loteamentos, espaço público e espaço privado, estabelecem requisitos jurídicos para os registros da propriedade, regulamentam as taxações.

Além desta característica reguladora, o Estado age diretamente na produção do espaço público quando concede anistias em áreas irregulares, promove obras viárias, promove transporte público, cria equipamentos públicos em áreas pública, promove habitação por meio de financiamento imobiliário e por meio de promoção de habitação de interesse social, programas de atuação em cortiços e programas de atuação em favelas.

No caso estudado tratamos da produção de habitação de interesse social, em que o Estado promove habitação para uma parcela da população de baixa renda. Esta modalidade de política pública age em paralelo a outras formas de ocupação do espaço urbano, e pode ser considerada numericamente pequena em relação à produção do espaço pelo mercado imobiliário. Compreendendo a atuação do Estado na produção de política de interesse social é possível observar as forças que atuaram e atuam na produção do espaço urbano e seus desdobramentos na vida cotidiana das pessoas. Um dos dados da pesquisa refere-se à busca por terrenos baratos e sem infra-estrutura para a produção de habitação de interesse social, o que promove desdobramentos em termos de investimentos em infra-estrutura e tem efeitos nas trajetórias dos moradores, seja do ponto de vista dos seus deslocamentos diários, seja do ponto de vista do seu orçamento familiar, seja do ponto de vista do acesso a serviços públicos e acesso ao mercado de trabalho, seja do ponto de vista das dinâmicas de sociabilidade no bairro. Os dados estatísticos disponíveis possibilitam a observação de alguns elementos acerca da vida dos moradores, como renda, ocupação e escolaridade. A análise destes dados possibilita agregação de situações e comparações com outros distritos, por exemplo. Para a compreensão de fenômenos de ordem mais qualitativa e dinâmica, como a percepção do bairro, as facilidades e desafios que ele coloca à vida cotidiana, a pesquisa lançou mão 
de uma investigação de ordem qualitativa. A escuta das trajetórias dos moradores num edifício da Cidade Tiradentes possibilitou levantar elementos qualitativos acerca dos desdobramentos da política habitacional na vida dos moradores. Reiterando, essa escuta é fundamental na reflexão acerca do papel das políticas públicas.

Estes temas elencados na introdução, como o papel do Estado na produção do espaço social, as forças relacionadas à produção do conjunto Cidade Tiradentes e o olhar para a realidade dos moradores foram abordados ao longo de três capítulos.

O papel do Estado na produção do espaço social foi abordado pela observação da história da urbanização em São Paulo. A sua atuação em relação à promoção da habitação foi considerada ao longo do tempo, ao mesmo tempo em que se abordam dinâmicas urbanas paralelas, como o auto-empreendimento da casa própria e a periferização das cidades.

A análise da atuação do Estado na produção do espaço social é recortada no segundo capítulo, em que se aborda o papel dos governos no município de São Paulo em relação à política habitacional de interesse social e as forças produtoras do conjunto habitacional Cidade Tiradentes. Observa-se a população do conjunto habitacional Cidade Tiradentes pela lente dos dados agregados.

As narrativas dos moradores do prédio são apresentadas no terceiro capítulo, em que se abordam também aspectos metodológicos da pesquisa. 


\section{Capítulo 1 - Aspectos históricos da configuração urbana de São Paulo}

O propósito deste capítulo é apresentar um panorama das dinâmicas urbanas ao longo do tempo na cidade de São Paulo, com o olhar voltado para o papel do Estado na produção do espaço social.

Descrever dinâmicas espaciais é ao mesmo tempo descrever dinâmicas dos grupos sociais na cidade, imbuídos de seus papéis relacionados às forças econômicas. A origem das relações econômicas está na relação entre a Colônia e a Corte Portuguesa. Seus desdobramentos são uma crescente absorção da dinâmica econômica pelo país (em relação à economia mundial, por suposto), acompanhada pela intensificação dos processos de uso do espaço.

Neste processo, as relações sociais e as formas de uso e ocupação do espaço tornam-se progressivamente mais complexas. As relações sociais se expressam no espaço, nas vias definidas por modos de circulação, nos lotes que configuram bairros e nas expressões arquitetônicas dos edifícios públicos e privados. Dialeticamente, as relações sociais entre grupos e instituições, indivíduos e instituições, são também delineadas pelas possibilidades de apropriação do espaço urbano e suas mediações. Neste capítulo, a abordagem desta relação dialética entre sociedade e espaço seguiu o fio condutor da história urbana de São Paulo. Ao abordar formas de uso do espaço, procurou-se demonstrar suas implicações para as relações sociais. Reciprocamente, ao abordar as relações políticas, sociais e econômicas, dos grupos e das instituições, procurou-se abordar as suas reverberações nas formas de uso e ocupação do espaço. Desenha-se, no vai-e-vem destas leituras, a cidade atual, as práticas nela vivenciadas e os significados nela produzidos.

O objetivo deste capítulo é o entendimento dos processos de configuração urbana em São Paulo que orientar as práticas urbanas e a dotação de sentidos pelos sujeitos sociais. Embora partindo da busca de sentidos gerais para a experiência de viver 
em São Paulo, a genealogia da pesquisa ancora-se em questões específicas, que derivam da busca de sentidos da experiência de viver num conjunto habitacional na periferia de São Paulo no século XXI.

A experiência de viver na Cidade Tiradentes está profundamente relacionada com o entendimento do que é a cidade de São Paulo hoje, dentro do contexto social, político e econômico mundial. Este entendimento parte de olhares teóricos constituídos dentro da história do pensamento social brasileiro. Dentre as possibilidades de descrição mais relevantes para esta conceituação estão o amplo campo das ciências sociais e dos estudos urbanos ${ }^{1}$ que entendem aspectos da cidade como expressão de atraso (teoria da marginalidade); ou tratam as questões urbanas em termos de segregação; ou, ainda, assumem a perspectiva de que São Paulo é uma capital inscrita na dinâmica das chamadas cidades globais.

Uma gama de estudos urbanos que nos interessa encontrou consonâncias com as teorias sociológicas e econômicas da dependência, segundo as quais a economia brasileira estava atrelada de forma submissa à economia mundial, relação esta de que derivava a pobreza urbana, resultante de uma dinâmica de desigualdades regionais e processos migratórios mais intensos do que o crescimento dos empregos nas cidades grandes. A crítica a esta visão incorpora o conceito de exército industrial de reserva, a presença de um enorme contingente de força de trabalho não incorporada ao mercado de trabalho que pressiona a massa salarial para baixo, realizando os lucros provenientes da superexploração da força de trabalho dentro da economia à reboque das economias centrais. Os estudos de sociologia urbana estavam atrelados a uma leitura macrossociológica segundo a qual a cidade era vista como o espaço de solidificação das relações entre capital e trabalho. Eles beberam na fonte do urbanismo marxista, de trabalhos como o de Castells (1983), por exemplo. Neste trabalho, Castells analisa a cidade em termos da expressão espacial da concentração dos meios de produção, de unidades de gestão e de meios de reprodução da força de trabalho necessária, assim como da distribuição de mercadorias solicitadas pelo mercado. Todas as configurações

\footnotetext{
${ }^{1}$ Uma leitura da sociologia urbana pode ser encontrada em Marques \& Torres (2005).
} 
urbanas resultam desta relação, em que estão desigualmente atuantes o capital (os meios de produção) e o trabalho.

Os estudos urbanos a partir das décadas de 1970 e 1980 observam o crescimento das periferias nas grandes cidades brasileiras. Seu esforço descritivo produz teorias acerca da produção destes espaços. ${ }^{2}$ Descrevem-se e são analisados processos como o auto-empreendimento da casa própria nas periferias. Os analistas urbanos estavam em campo quando os fenômenos da resistência à ditadura militar da década de 1980 cresciam, com o fortalecimento do movimento operário e dos movimentos sociais nos bairros. Estes fenômenos passam a ser o objeto de estudo dos trabalhos urbanos em São Paulo. ${ }^{3}$

Esta abordagem possibilitou o crescimento da antropologia nos estudos urbanos, a partir de estudos minuciosos sobre os moradores da periferia e suas vidas. ${ }^{4}$

Como herdeiro desta tradição situa-se o presente trabalho, informado por esta literatura e orientado pela pesquisa empírica.

\footnotetext{
${ }^{2}$ Como no trabalho de Maricato (1982).

${ }^{3}$ O trabalho emblemático desta virada é o de Sader (1988).

${ }^{4}$ Como em Telles (1992).
} 


\section{Genealogia da Segregação em São Paulo}

São Paulo é uma cidade que abriga uma diversidade grande de situações sociais, expressas no seu ambiente construído. O ambiente construído é manifestação dos tempos sociais e das relações sociais ao mesmo tempo em que os orienta. É compreensível, portanto, que as desigualdades sociais estejam expressas no espaço, não apenas na expressão da arquitetura ou no tamanho das residências, mas também nas formas de acesso e nas diversas formas de expressão da infra-estrutura urbana. Estas expressões da cidade são resultantes de processos históricos. A abordagem histórica é relevante, pois esclarece aspectos dos papéis que diversos atores tomaram ao longo do tempo na construção da cidade, especialmente o Estado, os grupos de interesse ligados ao capital e os grupos ligados ao trabalho.

Estes três atores assumem faces diversas ao longo do tempo. No tempo do Brasil Colônia, o Estado era a figura da Coroa Portuguesa, cujos braços alcançavam o território da cidade por meio de suas representações oficiais. Os grupos de interesse do capital estavam ligados à Corte e os grupos ligados ao trabalho eram os escravos.

São Paulo na época do Brasil Colônia era uma cidade na qual estabelecia-se um padrão de tensão na convivência entre senhores de escravos com suas imensas terras concedidas e o poder que isso lhes conferia e escravos vivendo nas contra-condutas. Os escravos criavam espaços de interferência na realidade da cidade, fosse como demandantes em processos judiciais, fosse como agentes presentes nas relações privadas das famílias de posse, fosse criando resistência ao modo de vida dos brancos, nos quilombos. A cidade era dividida entre brancos em terras concedidas e negros escravos, e as formas de vida e de uso dos tempos destes dois grupos eram diferentes em tudo ${ }^{5}$, embora os usos se misturassem no espaço. A cidade era apropriada de formas

\footnotetext{
${ }^{5}$ Se aos brancos cabia a vida citadina, aos escravos cabia, pela relação de dominação, a vida de trabalho. Culturalmente, os brancos importavam uma cultura européia ao passo que os negros escravos cultivavam suas raízes religiosas e culturais africanas, como forma de união e resistência. A historiografia e os registros literários de Machado de Assis dão conta de relações mediadas entre negros escravos, brancos proprietários e uma camada intermediária, de homens livres do clero, ex-escravos e agregados. A característica do sujeito, a cor ou sua condição social, eram fortemente marcantes do comportamento
} 
diferentes por eles, embora brancos e escravos convivessem na mesma região. Como relata Rolnik (1981), a diferença estava inscrita no corpo de forma inequívoca, pela cor da pele, reforçada pela forma de se vestir e pelas diferenças culturais. Segundo a autora, a superação da escravidão inscreveu uma igualdade entre ex-escravos e senhores de escravos que não era desejada pelos senhores de escravos. A dominação se manteve com a discriminação em relação à apropriação dos espaços da cidade, no processo de segregação sócio-espacial.

A noção de segregação está relacionada, pois, à forma como os diversos grupos usam o solo e paulatinamente criam uma cidade pautada por acessos e restrições. $\mathrm{O}$ conceito de segregação sócio-espacial é nítido nos casos em que ele é enunciado oficialmente, como nos guetos de Varsóvia no início do século XX. No caso das cidades brasileiras, o acesso de todos os grupos a todos os espaços da cidade é, em tese, livre. As mediações que vão sendo construídas é que criam diferentes modos de acesso e diferentes restrições ao uso do espaço. A mediação fundamental do uso do espaço é a propriedade privada, que delimita o acesso ao solo. Em outros casos, como nos edifícios públicos, o acesso é livre, mas nem sempre é percebido como tal. Expandindo o raciocínio da segregação urbana, bairros são mais ou menos "acessáveis" a depender das suas características e dos meios de deslocamento até eles. Os acessos e restrições aos espaços da cidade orientam formas de vida e tempos sociais, reforçando aspectos da desigualdade econômica. Nesta dinâmica, na atualidade, estão em jogo os meios de transporte, a localização dos empregos, as formas de acesso à moradia e a oferta de serviços. Nas cenas sociais, as distinções são visíveis não apenas nos cenários, mas nos atores. Elas são visíveis nos corpos e no comportamento esperado dos atores, reproduzindo situações sociais, demarcando o lugar esperado de cada um. O lugar do escravo na sociedade escravocrata era a senzala, embora toda a sua conduta tenha criado resistências, como foi mencionado. O local da mulher branca era a família e o seu círculo social, e o lugar do homem branco, o mundo das negociações envolvendo o comércio e o dinheiro. Ao longo do tempo essa caricata configuração transforma-se qualitativamente: os escravos tornam-se homens livres e ao mesmo tempo assumem um

esperado, das permissões e relações de dominação (entre senhores que dispunham dos escravos como mercadorias) e de favor (entre agregados e senhores), como analisou Schwarz (1992). 
lugar variável, em tudo diferente do lugar dos homens livres brancos, profissionais liberais ou do clero, em função de como se fixam no território. O lugar da mulher, por outro lado, diversificou-se, chegando ao mundo do trabalho (embora sempre numa condição média inferior ao do homem e com restrições a ocupações), permanecendo no universo familiar.

A segregação é, pois, um conceito social, e não apenas urbano, que envolve a compreensão de que as relações entre indivíduos são desiguais, a cada cena social. A desigualdade se manifesta como desigualdade de gênero, desigualdade de classe, desigualdade de grupo religioso, desigualdade de raça. A expressão espacial da desigualdade inscreve no solo urbano as formas de apropriação da riqueza. A segregação urbana é um fenômeno da desigualdade de classe. A gênese do processo de segregação urbana diz respeito à forma como o acesso, o uso e a propriedade da terra foram institucionalizadas na Província de São Paulo.

Nos primeiros séculos de colonização portuguesa os povoados no sudeste eram dispersos e sua importância econômica era pequena. A pujança econômica localizava-se no nordeste em decorrência da exploração da cana de açúcar e do comércio de escravos. O papel dos povoados era de oferecer uma base para a administração colonial e para a Igreja. ${ }^{6}$ A legislação fundiária era baseada na concessão de sesmarias pela Coroa. As terras eram propriedade da Coroa portuguesa que concedia o uso do solo, chamado de sesmarias. A Coroa tributava a produção, e não tributava a terra. As terras que não eram produtivas voltavam à Coroa (as chamadas terras devolutas). As câmaras adquiriram a atribuição de ceder terras, e de abrir ruas ao passo que os habitantes que adquiriam direito de uso deveriam fazer uso produtivo dos terrenos pela agricultura ou por construção de edificações. Simoni (2002) analisa que mesmo após a Independência, quando as câmaras passaram a legislar apenas sobre as terras urbanas, houve concentração de terras nos arredores das cidades. A Câmara desapropriava terras para arruar e indenizava os proprietários, que com o dinheiro construíam edificações, numa lógica que perdurou até o século XX. Uma instituição pública remunerava, portanto, proprietários de terras que concentravam o uso do solo nas áreas centrais da cidade. A

\footnotetext{
${ }^{6}$ O trabalho de Simoni (2002) explora a legislação de terras em São Paulo de 1840 a 1930.
} 
compra e a venda de terras do Rocio (arredores da Vila destinados ao uso comum dos habitantes mediante concessão feita pelo Conselho) era modesta, porque a terra não tinha valor econômico. Os brancos tinham acesso às terras (tinham bons relacionamentos com os governantes) e aos meios de produção (incluindo os escravos) ao passo que para os colonos livres o acesso às terras em concessão era mais difícil. Depois da Independência, até 1850, a forma de acesso à terra passou a se generalizar por meio da posse, gerando conflitos entre sesmeiros e posseiros.

Pouco antes da Lei de Terras de 1850, foram construídas na cidade de São Paulo as primeiras estradas de ferro. Impulsionada pela economia cafeeira em gestação, a estrada de ferro Santos Jundiaí foi construída entre 1855 e 1875.

A Lei de Terras de 1850 foi o divisor de águas da questão fundiária no Brasil e em São Paulo. A Lei de Terras estabeleceu normas jurídicas para a propriedade da terra, que era, desde a abolição do sistema de sesmarias com a Resolução 76 em 1822 até então, simplesmente ocupada de forma legítima. Não por acaso a questão da propriedade da terra foi equacionada no plano jurídico junto à Lei Euzébio de Queiroz, que suspendia a importação de escravos. A Lei Euzébio de Queiroz procurava impulsionar a colonização por meio da ampliação da imigração para aumentar a oferta da força de trabalho. Por outro lado, a necessidade da regulamentação da terra respondia à crescente economia cafeeira no centro-sul, que substituía a decadente economia açucareira do nordeste. A Lei de Terras estabelecia que o acesso às terras só poderia ser realizado mediante a compra do terreno. O seu objetivo era resolver o problema da propriedade da terra e ampliar os fluxos imigratórios. Aos ocupantes, até aquele momento, foi dado o título de proprietários. As terras não ocupadas, propriedades do Estado, eram vendidas em leilão mediante pagamento à vista. A lei redefiniu o conceito de terras devolutas como terra devolvida ou terra vaga ou inculta, pois elas passaram a serem vendidas. O produto da venda de terras devolutas destinava-se a um fundo a ser aplicado na medição e marcação das terras (atribuição do governo). A Lei revogava as formas de acesso à terra por concessão ou posse, salvo em caso de fronteira ou em reservas indígenas. Simoni (2002) mostra em seu trabalho, contudo, que exceções 
importantes foram mantidas em relação ao regime de compra e venda, revalidando as concessões das sesmarias existentes. ${ }^{7}$

Para a compra e venda de terras devolutas era necessária a legitimação das terras por meio da demarcação dos limites. $\mathrm{O}$ acesso a esta demarcação e a compra de terras ficou nas mãos dos grupos de antigos senhores representados na Câmara municipal. Por outro lado, a imprecisão técnica das demarcações facilitou a abertura de negociações privadas em torno da terra.

Em 1880, a elite cafeeira colocava-se à frente na criação de núcleos-colônias como complemento à política de imigração. Reiterando a visão racista dos brasileiros de então, a política de apoio à imigração aconteceu pari-passu à abolição da escravatura. Com a abolição da escravidão em 1888, os trabalhadores recém libertos tornam-se trabalhadores livres e sem acesso à propriedade. Mesmo entre os trabalhadores europeus recém-chegados a São Paulo, o acesso à terra era restrito, pois era realizado por meio de recursos financeiros, de que eles não dispunham. Depreende-se que o acesso à terra mediava também o valor da reprodução da força de trabalho, que estava próximo à capacidade de sobrevivência dos trabalhadores.

Duas observações do período imperial contribuem para a compreensão do fenômeno da segregação espacial. A primeira diz respeito à dimensão simbólica que a abolição da escravidão teve na província de São Paulo. A segunda nos remete ao sustentáculo material desta dimensão simbólica.

Na São Paulo antiga os escravos trabalhavam, e os senhores exerciam suas atividades de homens livres, como a política, o comércio, as relações financeiras, o mando na propriedade agrícola. A distinção do lugar de cada um era evidente, sendo

\footnotetext{
7 "Uma observação fundamental a fazer, portanto, é que os dispositivos da Lei de Terras e seu regulamento não generalizaram a venda e compra, abrindo exceções que não podem ser menosprezadas. Em especial, também não aboliram as concessões de terras, ao determinar a revalidação das sesmarias e outras concessões do governo Geral ou Provincial, mantendo parte importante das terras possuídas segundo a forma de propriedade definida nas Ordenações. Além de manter um grande número de terras enquanto concessões revalidadas, e ser omissa quanto às concessões municipais, definiu o aforamento perpétuo como forma de aquisição dos lotes resultantes da divisão de terras devolutas reservadas para povoações, com o que a ocupação urbana continuava determinada pelo sistema concessionário com origem colonial.” Simoni (2002, p. 43).
} 
portanto, desnecessários signos espaciais para marcar as diferenças. $\mathrm{O}$ acesso a diferentes espaços sociais demarca a diferença de modo a re-estabelecer a dominação.

Do ponto de vista material, a geração do valor desloca-se da propriedade dos escravos (que eram comercializados, e cuja posse implicava em patrimônio) para a propriedade da terra, que passa a ter valor com a Lei de Terras.

A nova forma de poder era elitista, como ficou claro por meio do novo traçado urbano que se desenhava na cidade. As relações de trabalho eram desiguais, no sentido que a reprodução da força de trabalho dava-se no nível da sobrevivência, e o acesso ao solo era, pela Lei de Terras, restrito àqueles que detinham propriedades, heranças das relações imperiais. As restrições do acesso à terra denotam o processo de segregação sócio-espacial. Aos trabalhadores livres coube a solução de moradia nos cortiços próximos ao centro da cidade. Os proprietários de terras que haviam se tornado cafeicultores, banqueiros e industriais, passaram a ocupar terras altas, partindo dos campos Elíseos (em 1879) para Higienópolis (em 1891) e para região da Avenida Paulista (inaugurada em 1891), bairros distantes das várzeas inundáveis dos rios Tamanduateí e Tietê.

Os novos detentores de poder, republicanos, inspiraram-se nas reformas urbanas da Europa, nas aberturas de largas vias em Paris, com a reforma do barão de Haussmann, para singrar as ruas estreitas do centro da cidade e abrir largas avenidas. Os ideários de higiene com o combate às epidemias estavam na base do discurso e da prática dos republicanos. Eles buscavam a imagem de uma cidade moderna que não estaria mais associada ao passado escravista.

O Plano de Avenidas do prefeito Prestes Maia (entre 1935 e 1945) representa a atuação do Estado na definição urbana da cidade, desde a realização de obras viárias à gestão de serviços urbanos.

O Plano de Avenidas vem no bojo de reformas urbanas que tiveram início no começo do século, com os sanitaristas. As reformas eram promovidas por incorporadores que aprovavam leis específicas e conquistavam serviços públicos para as 
regiões nobres. Enquanto nos bairros operários o esgoto corria a céu aberto na região da Avenida Paulista havia rede de água e esgoto, iluminação e calçamento. ${ }^{8}$

Os registros sobre a cidade de São Paulo no final do século tratam sobretudo da aspiração da cidade à modernidade. Quem se debruçou sobre os registros, como Nabil Bonduki, relata a inexistência de informações sobre a moradia dos trabalhadores em São Paulo. Não fosse pela intervenção do movimento higienista nos cortiços do centro da cidade, pouco saberíamos das condições de moradia de boa parcela da população. Este silêncio enuncia a visão de uma cidade que teria crescido pela força do empreendedorismo dos proprietários e do saber técnico, omitindo o papel fundamental dos trabalhadores. Estes, por sua vez, tinham seu espaço na cidade restrito. Embora a circulação pudesse ser livre, os trabalhadores estavam atrelados à fábrica, e a vida operária girava em torno do bairro em que a força de trabalho se reproduzia. Fica evidente nesta relação que o tempo social do trabalho está relacionado à vivência restrita do espaço, o que torna a cidade segregada.

Os incentivos à imigração a São Paulo, a partir do final do século XIX, expandiram a cidade. $\mathrm{O}$ crescimento do cultivo de café demandava mão-de-obra em quantidade. A cidade recebia um grande número de imigrantes. Os registros nos falam de 900 mil imigrantes entre 1886 e 1900.

A cidade crescia e se diversificava. Atividades como o pequeno comércio, a indústria nascente e o pequeno empreendimento imobiliário cresciam. O pequeno empreendedor era geralmente um imigrante com algum capital, que investia na compra do terreno e na construção de inúmeras casinhas, para abrigar famílias de trabalhadores. A construção de cortiços era, pois, uma atividade bastante rentável.

Os relatórios pesquisados por Bonduki (2004) tratam de cortiços caracterizados pela má qualidade das construções e pela insalubridade das condições, sobretudo de escoamento de esgoto e água. A leitura que se fazia destas condições respaldava a ação política de intervenção e de controle sobre as habitações, a iniciar pelas desinfecções,

\footnotetext{
${ }^{8}$ Rolnik (2001).
} 
continuando com obras de saneamento, distribuição de água e coleta de esgoto, de forma tópica, e culminando com a criação de legislação de controle e uso do solo.

O Código de Posturas do Município de São Paulo de 1886 determinava área mínima de $5 \mathrm{~m}^{2}$ para cada cômodo, e de espaçamento entre cada linha de cortiços de 5 metros, água disponível em poços (uma para cada habitação) e uma latrina para cada duas habitações. Além disso, a Lei regulamentava que os cortiços não poderiam estar junto a áreas comerciais. A Lei 493, de 1900, não permitia cortiços fora do padrão. A existência de todas as leis, no entanto, não significava que as construções as seguiam. Pelo contrário, já no início do século XX começam a serem construídas habitações fora das normas, paralelamente a uma normatização cada vez mais restritiva.

A presença de normas paralela à presença de uma intensa burla à regra faz parte da história urbana das grandes cidades brasileiras. Este fenômeno foi analisado por parte da literatura urbana como expressão de duas cidades: a "cidade legal", por um lado, e a “cidade ilegal”, por outro lado. Uma das cidades estaria dentro das regulamentações, e outra crescendo ao largo das normas, em trabalhos como o de Rolnik (1997). Aprofundando esta análise, Maricato (1996), demonstra que as irregularidades são na verdade constitutivas do processo de urbanização, pois a forma de criar as normas evidencia na sua gênese a intenção da segregação.

Se por um lado autores como Rolnik (1997) defendem a existência de cidades paralelas, as críticas a este modelo interpretativo demonstram que não se pode falar em dois processos paralelos de urbanização, mas num processo unitário, no qual o respeito ou o desrespeito às normas são condições de apropriação do uso do espaço pelos diferentes grupos sociais. Esta apropriação diferenciada, por seu lado, não é planejada. Não há uma dicotomia entre a cidade dentro das normas (trabalhistas, por exemplo, ou fundiárias), e a cidade do desrespeito à lei. Estes processos estão, ao contrário, imbricados na mesma origem, pois o mercado se estrutura prevendo e atuando dentro de uma certa parcela de informalidade das relações. No caso fundiário, em relação à indústria da construção civil, por exemplo, é condição para o lucro esperado da indústria que o trabalhador da ponta não conte com garantias trabalhistas. Do mesmo modo, dentro das práticas urbanas cotidianas, o legal e o ilegal estão mesclados numa fronteira 
pouco clara ${ }^{9}$. A realização dos lucros dos empreendedores imobiliários do começo do século, por exemplo, se dava a partir da burla às normas legais. Este tipo de burla era conhecido pelos técnicos da prefeitura, o que não implicava numa re-orientação da legislação. Pelo contrário, a lei fazia-se cada vez mais rígida.

O pensamento estruturado a partir do entendimento desta lógica ilumina uma contradição básica na formação social brasileira. A raiz desta discussão está em "As idéias fora do lugar", em que Schwarz (1992) retorna sua análise à sociedade escravista. A contradição básica é que a sociedade brasileira queria-se moderna e liberal, mantendo sua base fundiária e escravocrata. A base material da geração do valor era omitida por todos, que voltavam suas atenções para as idéias que circulavam na Europa, de liberdade, igualdade e fraternidade. A mediação que estava presente neste mundo não era a do contrato liberal. Uma relação de favor baseia-se na arbitrariedade do poder e do mando, e não numa medida igualitária. A lei cumpre o seu papel de formular idéias liberais, mas as práticas sociais são da arbitrariedade e do mando. Paralelamente, a literatura sobre a cidade ilegal e a cidade legal (ou a cidade informal e a cidade formal) demonstra a ineficácia da norma na sociedade brasileira, em que o contrato liberal é mediado o tempo todo pelo arbítrio. Ao lado da norma há sempre um mecanismo para burlar a regra, e ele é estruturante da economia e das relações de poder no Brasil. ${ }^{10}$

O discurso sobre normas e arbitrariedade, de tão presente na sociedade brasileira, é comumente apropriado como um discurso ideológico ou presente em falas moralistas. Mais do que uma denúncia moral, o que este debate pode esclarecer é a fragilidade do pacto social liberal. O pacto social liberal é baseado no contrato e na norma como mediações universais das relações. Ele é pautado pela funcionalidade das instituições. A política liberal é a política que existe dentro das instituições e suas normas de funcionamento. Ao considerarmos o pacto liberal frágil podemos exercitar

\footnotetext{
${ }^{9}$ Esta imbricação entre legalidade e ilegalidade nas periferias urbanas dos anos 2000 foi descrita por Telles (2006).

${ }^{10}$ Oliveira (2003).
} 
uma compreensão mais abrangente de política, que considera a constituição das instituições como próprias da política. ${ }^{11}$

A análise da sociedade paulistana do início do século $\mathrm{XX}$ pode contribuir para este exercício. A sociedade paulistana da época era bastante diversificada. A República trouxe a expansão de grupos sociais. Ao mesmo tempo, o modelo político não significou a constituição de uma República liberal nos moldes francês ou inglês. Foi ampliada a burocracia do estado, elemento que suplantou as orientações imperiais instituindo uma dinâmica de impessoalidade própria da burocracia do estado moderno. Se, por um lado, os grupos ligados ao desenvolvimento das técnicas e da burocracia buscavam uma cidade regulamentada e organizada segundo normas convencionadas; por outro, grupos ligados ao crescente mercado imobiliário, de portes variados, organizavam sua conduta no sentido do lucro. Estes grupos de investidores tinham disponíveis recursos que não seriam facilmente aplicados na indústria, e havia, por outro lado, uma demanda grande por habitação. Como nos informam os pesquisadores dos documentos históricos, a construção de habitação para as classes trabalhadoras era um bom negócio. ${ }^{12} \mathrm{O}$ que se depreende deste movimento é a estrutura hierarquizada da sociedade, a existência de grupos com poderes desiguais, e o fracasso no sentido de um consenso formal em torno da questão urbana por parte de todos os grupos sociais. Este processo evidencia a política do momento.

Cabe esclarecer o conceito de política com o qual se aborda esta dimensão histórica da constituição urbana. "Política é a demanda da parcela dos sem parcela", segundo a formulação conceitual de Rancière (1996). A política nasce de um dano primeiro, do escândalo de que um grupo desconsiderado como tributário de uma parcela, demanda a sua parcela. É um movimento que instaura o dissenso e institui a necessidade de outra lógica para as relações. A existência da parcela dos sem parcela revela que a política é dissenso e só pode existir na definição das falas de dos corpos, no

\footnotetext{
11 A fragilidade do pacto social liberal foi analisada e aprofundada no debate entre Franco (1983) e Schwarz (1992).

${ }^{12}$ Bonduki (2004).
} 
encontro entre a lógica policial e a lógica igualitária. Por ordem policial Rancière (1996) entende a:

\begin{abstract}
"ordem dos corpos que define as divisões entre os modos do fazer, os modos de ser e os modos do dizer, que faz que tais corpos sejam designados por seu nome para tal lugar e tal tarefa; é uma ordem do visível e do dizível que faz com que essa atividade seja visível e outra não o seja, que essa palavra seja entendida como discurso e outra como ruído" (Rancière, 1996, p. 42).
\end{abstract}

A política é, pois, aquilo que institui no mundo público um dissenso em torno da compreensão do outro e da redefinição de dinâmicas sociais. Essa definição parte do entendimento de que a sociedade é formada por desiguais, em torno dos quais a definição da igualdade e da diferença se coloca. Essa definição, sobretudo, supera a naturalização da formulação clássica de política e das instituições liberais. Assim, a política não se coloca apenas nos espaços institucionais, mas é o jogo segundo o qual estes espaços institucionais se definem. Neste jogo estão presentes as construções discursivas que definem e redefinem condutas esperadas. Aquilo que se cristaliza nas instituições, neste sentido, pode vir a ser o fim da política, e não o seu exercício. ${ }^{13}$

Voltando ao objeto em questão, o poder burocrático e o poder da técnica, de natureza burguesa, foram suplantados pelo poder da expansão imobiliária, fundado na renda da terra. Em termos de grupos sociais, o grupo de proprietários tornou-se hegemônico. Este processo ocorreu porque conceitualmente o espaço não é um meio de produção, mas está ligado à reprodução da dinâmica urbana que estrutura as relações

13 "Expliquemos melhor esse postulado, pelas suas implicações. A política é um assunto de sujeitos e um movimento social faz política não no processo de identificação coletiva para daí reivindicar uma parcela. O sujeito político não é aquele que reclama apenas sua parcela, mas quem questiona a distribuição hierárquica dos lugares e das partes nesta reclamação singular. Só há sujeito político neste movimento de particularização e universalização. Assim, um modo de subjetivação não cria sujeitos do nada. Ele os cria transformando identidades definidas da repartição das funções e lugares em experiências do litígio. A subjetivação política se dá na relação da potência igualitária com a lógica policial, na capacidade de inventar uma cena e ainda deslocar os lugares estabelecendo relações de mundos em litígio.” Miagusko (2008, p. 48). 
capitalistas na cidade. Diferentemente do meio de produção, cuja posse engendra o lucro, a propriedade privada da terra não gera por si só o lucro, mas está na dinâmica dentro da qual a disputa pelo espaço cria o seu preço. O capital imobiliário está ligado ao monopólio do uso do espaço, que abrigará uma atividade produtora de lucro. ${ }^{14}$ É nestes termos que a propriedade está associada ao poder econômico que se expande como poder político. Do ponto de vista da dinâmica da cidade, no lugar de obra, lugar de valor de uso, festa e prazer, a cidade torna-se um objeto relacionado ao valor de troca, como analisou Lefébvre (1991).

Na configuração burguesa da cidade, no início do século, os trabalhadores, possuidores apenas da sua força de trabalho, representavam a parte mais fraca da equação urbana. Sem capital para a disputa do monopólio urbano, estavam sujeitos ao salário e às relações de exploração de sua força de trabalho. Além disso, no início do século a força de trabalho era composta por trabalhadores imigrantes, cuja representatividade política era ainda frágil e a repressão à sua organização, policial.

Todo o modo de vida dos trabalhadores estava associado ao trabalho e ao consumo para a sobrevivência. Como já foi dito, sua vivência urbana era geograficamente localizada junto às fábricas e às suas moradias, os cortiços (forma de habitação mais generalizada no início do século XX). Acompanhando o processo de concentração de terra na mão de uma classe de proprietários, outros monopólios foram surgindo, como o monopólio dos serviços de transporte. As duas formas de lucro para estes grupos eram fortemente estruturantes do espaço urbano. O monopólio no sistema de transportes em São Paulo orientou a expansão urbana, tanto do ponto de vista da abertura das vias quanto do ponto de vista da concentração de moradias populares, de maneira forte e intensa, em regiões periféricas. Nas primeiras décadas do século XX, os

14 "O 'capital' imobiliário é, portanto, um falso capital. Ele é, sem dúvida, um valor que se valoriza, mas a origem de sua valorização não é uma atividade produtiva, mas a monopolização do acesso a uma condição indispensável àquela atividade." Singer (2002, p. 22).

SINGER (1982) analisa a dinâmica urbana do ponto de vista da reprodução do capital: a explosão da especulação imobiliária é uma atividade que decorre da produção de benfeitorias que o Estado faz no solo urbano, e a cidade volta-se às atividades produtivas em torno dos bairros que se tornam, assim, localizações. Há duas formas de capital imobiliário, segundo Harvey: este de que nos fala Singer, que explora a cidade para se apropriar da renda (os proprietários e os incorporadores) e aqueles que obtém lucro a partir do espaço urbano (construtoras e financeiras). 
serviços usados pelos trabalhadores, como transporte, energia e telefones, eram controlados por uma única empresa: a Companhia Light. A Companhia Light, a partir da década de 1920, tomou como sua prioridade o abastecimento de energia na região sudoeste da cidade e os serviços de transporte público foram relegados a segundo plano, mesmo porque seus custos aumentavam e a tarifa estava congelada. Os registros mostram que em 1924, surgiram os primeiros ônibus, clandestinos. A Companhia Light à época fez uma proposta de instalação do metrô na região central da cidade com ramificações para as regiões mais distantes através de bondes. A proposta, entretanto, foi vencida pelo Plano de Avenidas de Prestes Maia, por meio da abertura da avenida Nove de Julho, uma das avenidas radiais propostas no plano.

A análise do Plano de Avenidas elaborada por Leme (1990) deixa entrever um plano ambicioso cujo impacto na cidade foi intenso. A autora mostra que termos como "sanear" bairros como o Bexiga são a tônica da obra, cuja realização configurou o traçado urbano de São Paulo em centralidade e abriu espaço para a expansão periférica. No plano previu-se o deslocamento por bondes realizado apenas nas áreas centrais. As radiais deveriam dar vazão a um transporte mais rápido, os "metropolitanos sem trilho". ${ }^{15}$ O Plano de Avenidas marca um momento de crescente intervenção do Estado no urbano, por meio de uma camada média de tecnocratas - engenheiros e arquitetos, urbanistas, de um modo geral, que instituíam e fiscalizavam regulamentações para o uso do solo e para a circulação urbana. De um modo geral, essa camada média agia na mesma via do desenvolvimento da economia, privilegiando a indústria automobilística incipiente, bem ao encontro dos caminhos da economia paulistana e brasileira, de um modo geral.

Do ponto de vista da estrutura urbana, a abertura das vias do Plano de Avenidas associou-se à expansão do modelo rodoviarista de transporte sobre pneus. Até então as camadas altas e os operários faziam seu deslocamento por meio de bondes, nas áreas centrais da cidade. A prefeitura, usando como argumento a execução do Plano de Avenidas, contrapôs-se à empresa Light que fazia o transporte por bondes. $\mathrm{O}$ transporte

\footnotetext{
${ }^{15}$ Leme (1990) enfatiza que o plano de Prestes Maia tinha em seu bojo um modelo de estrutura urbana: "mononuclear, de baixa densidade, ocupação extensiva do solo, sem barreiras para o crescimento da área urbanizável e com uma proposta de direções de crescimento.”Leme (1990).
} 
sobre bondes, bem como os demais serviços de abastecimento de luz e água da Companhia Light associavam interesses do capital cafeeiro aos interesses dos grandes grupos estrangeiros. A entrada da Companhia Light se fez no Brasil por meio da ferrovia. Do mesmo modo, a Cia articulava-se com a expansão do mercado imobiliário, comprando terras e vendendo glebas para a construção de bairros inteiros. A expansão urbana da atividade cafeeira (que também estava associado ao capital bancário e à indústria incipiente) deu vazão a uma demanda por transporte mais rápida do que os bondes: as classes altas passaram a andar de carros importados, artigos de luxo. O transporte metropolitano coletivo, aos poucos, foi se tornando primordialmente feito por ônibus. O plano de avenidas, de modelo radial perimetral, permitia a expansão da cidade ao longo dos córregos, que foram canalizados; ao mesmo tempo, sendo realizado o transporte via ônibus. Este modelo de expansão promoveu também a expansão das moradias para as regiões periféricas da cidade. Os preços dos terrenos nas áreas em que foram abertas as avenidas subiram muito, expulsando a população para áreas mais distantes. Os empreendedores imobiliários, como veremos, passam a optar pela venda de imóveis no lugar dos aluguéis, por causa da Lei do Inquilinato que congelou os aluguéis. De forma que as classes baixas passam a ocupar regiões periféricas da cidade, a partir da auto-empreendimento da casa própria. Ao mesmo tempo, a presença do transporte rodoviário coletivo, via ônibus, possibilitava o deslocamento dos trabalhadores das regiões periféricas às regiões centrais das cidades, onde localizavamse as fábricas e as atividades comerciais. 


\section{A questão habitacional e o surgimento da valorização da casa própria nos meios populares}

A questão habitacional já era uma questão importante para a cidade de São Paulo desde a abolição da escravidão e a chegada à província de centenas de milhares de imigrantes europeus. A crise habitacional, não apenas em São Paulo, mas em todo o Brasil, intensificou-se na década de 1930 quando a política de intervenção do Estado passou a ser a tônica dos envolvidos nas discussões públicas e na máquina pública, que crescia. A grande mudança na estrutura social que a chegada do Estado Novo promoveu foi a entrada maciça da figura do Estado nas questões urbanas, na dinâmica do mundo do trabalho e da produção e nas relações sociais com uma intensidade antes nunca vivenciada. Se a habitação até então era tratada no âmbito das soluções privadas (dos empreendedores privados), ela passou a ser uma questão de Estado, assim como a regulação do trabalho. Até a subida de Vargas ao poder político a intervenção do Estado nas questões de habitação era legislativa e de repressão, com ênfase sanitária e higienista. A partir de 1930 predominam nos documentos a visão de que a iniciativa privada não dá conta da criação de unidades habitacionais, sendo necessária a presença do Estado. É um momento de racionalização da questão urbana, de cunho positivista, que ganhou força com a criação das faculdades de ciências humanas (Faculdade de Filosofia, Letras e Ciências Humanas e Escola Livre de Sociologia e Política) e de institutos como o Idort (Instituto de Organização Racional do Trabalho). Ao mesmo tempo, órgãos públicos foram criados para dar conta da crise da habitação (como o Instituto de Engenharia, Carteira Predial do Instituto de Aposentadorias e Pensões e Fundação da Casa Popular), e nos discursos dos técnicos e dos políticos o papel do Estado era destacado como responsável pela promoção da habitação social.

Entidades de classe de arquitetos e urbanistas surgiram e foram consolidadas nesta época - o Instituto de Arquitetos do Brasil - IAB, o Instituto de Engenharia de São Paulo - IE, além dos cursos de arquitetura - Universidade de São Paulo e Universidade Mackenzie. A partir de 1940 a visão dos urbanistas deixou de estar 
voltada para grandes obras e passou a centrar-se na formulação de instrumentos de regulamentação do solo urbano. ${ }^{16}$ Apesar da crescente regulamentação do uso do solo, a expansão da cidade deu-se em loteamentos irregulares nas zonas periféricas, às vistas grossas do poder público municipal que obtinham dividendos políticos com os loteadores.

A política de desenvolvimento urbano ao largo da regulamentação urbana também estava relacionada à política nacional. Dentro do projeto nacionaldesenvolvimentista da Era Vargas a habitação era uma estratégia para a industrialização do país. Além da promoção da habitação social implicar num custo mais baixo da reprodução da força de trabalho, favorecendo a manutenção de baixos salários na indústria, ela também fortalecia um aspecto ideológico fundamental no processo de desenvolvimento urbano do Brasil: a casa própria.

A casa própria na periferia das grandes cidades, com todas as características rurais, era entendida pelos setores ligados aos poderes políticos e econômicos como um ganho em relação aos cortiços do centro da cidade. Bonduki (2004) defende que a opção da casa própria na periferia da cidade fazia parte de um projeto das elites para segregar a pobreza urbana. Em 1942 o congelamento dos aluguéis foi um golpe pesado para os investidores rentistas. Embora $70 \%$ da moradia fosse de aluguel, a defesa da casa própria tornou-se discurso predominante em todas as esferas sociais do país. A Lei do Inquilinato significou a redução de lucro dos setores rentistas e a orientação do governo de investimento no parque industrial. Do ponto de vista ideológico o discurso da defesa da casa própria implicava em defender o trabalho e seus frutos, ao mesmo tempo em que quebrava a identificação entre ricos e proprietários, permitindo às oligarquias a manutenção do seu poder político e econômico. O trabalho de décadas compensaria pelo seu efeito de garantir ao trabalhador o status de proprietário. Desde a Colônia o proprietário era identificado como o rico e destarte todos os trabalhadores dedicados poderiam legar à sua família este símbolo mais do que desejado, a casa própria. O sonho era acessível de forma que a ameaça do comunismo seria afastada. O binômio da

\footnotetext{
${ }^{16}$ Sobre a institucionalização da figura do urbanista no Brasil ver Feldman (2005).
} 
manutenção dos interesses das oligarquias e repressão política aos projetos revolucionários dos operários seria garantido pela domabilidade das camadas operárias.

\begin{abstract}
"A habitação operária torna-se, portanto, área crucial para a manutenção da ordem econômica, política e social. Além de ser um bem essencial para a sobrevivência do trabalhador, a moradia deveria tornar-se instrumento de transformação do trabalhador em proprietário, desempenhando um papel importante na criação de um modo de vida conservador e reproduzindo os padrões de comportamento moral e cultural burguês entre trabalhadores oriundos de vários países e longínquas regiões do país. E, além disso, deveria integrar o rol de iniciativas empreendidas pelo Estado, sob liderança do ditador Vargas, visando dar assistência às classes trabalhadoras." (Bonduki, 2004, p. 86).
\end{abstract}

Entre 1945 e 1965 consolidou-se no Brasil um estado forte e voltado para o desenvolvimento industrial. As cidades cresceram e sua expansão seguia o ritmo desse crescimento. A forma de provisão de moradia contemplava um pacto firmado entre os empresários e os governos na manutenção de baixos salários. A moradia deveria ter um baixo custo para poder ser acessada mesmo com baixos salários. Em lugar de destinar salários dignos que pudessem prover a moradia, o consenso político e econômico dos grupos ligados ao poder criou possibilidades de moradia compatíveis com o baixo salário, como o empreendimento da casa própria na zona rural. A zona rural era composta por loteamentos recém abertos por especuladores, sem serviços urbanos como rede de esgoto e água encanada, ou coleta de lixo. Os próprios trabalhadores construíam suas moradias nesses loteamentos, e trabalhavam nas fábricas e no comércio no centro da cidade. Concomitante ao processo de transporte rodoviário o auto-empreendimento da casa própria foi criando bairros periféricos nas quatro direções de São Paulo, sendo atenuada nas regiões em que encontrava obstáculos naturais, como a zona norte com a serra da Cantareira e a zona sul com as represas.

A casa própria era o empreendimento da vida do trabalhador. A evidência de seu sucesso e o prêmio pelo qual a vida de trabalho era compensada. Como nota Bolaffi (1982) a aquisição da casa própria se constitui como evidência de sucesso do trabalhador, ao mesmo tempo serve de poupança e desonera o orçamento familiar do aluguel. Num país em que os salários do trabalho eram historicamente achatados, a casa própria era a poupança de uma vida toda. $\mathrm{O}$ corolário comunitário da casa própria era $\mathrm{o}$ 
bairro e a criação de associações de amigos de bairro, voltadas para conquistas de infraestrutura nas regiões mais distantes da cidade. Como os estudos sociológicos demonstram, estas associações eram a base para a política clientelista que definiu a face de bairros em São Paulo: desde a anistia para os terrenos irregulares às melhorias urbanas, tudo era conseguido na base da troca de apoio político. Os resquícios desta política clientelista permaneceram na câmara municipal de São Paulo até a data em que se escreve essa dissertação. Trata-se de um entendimento de que o voto, expressão da política representativa (momento por excelência da política partidária) é algo que se destina para que o representante empreenda uma ação no sentido de beneficiar quem votou. A assembléia em que se legisla é, neste entendimento, um fórum em que se delibera o uso do fundo público em função da representatividade que tem maior força política partidária. Neste fórum são comuns alianças e acordos em função, sempre, de interesses eleitorais. A abstração do bem comum não está mais em debate, pois é como se a decisão sobre o mundo comum fosse já o ponto de partida, o mundo comum é o mundo dos trabalhadores e da disputa competitiva por trabalho e meios de vida. A política não delibera sobre questões constitutivas das formas de vida da sociedade, mas sobre meios pragmáticos de se obter vantagens em relação aos demais. ${ }^{17}$

Em relação ao auto-empreendimento da casa própria, a legislação fundiária era ignorada, e os loteamentos nas regiões periféricas ampliaram-se ao longo das décadas. A estrutura urbana surgia via de regra a posteriori, a partir da pressão dos moradores.

O Estado, entretanto, não era apenas uma peça de atuação micro-geográfica clientelista. O estudo de Bonduki (2004) discutiu a política habitacional durante o Estado Novo e nos sucessivos governos populistas até o golpe militar de 1964. Sua análise centra-se nos Institutos de Aposentadorias e Pensões e na Fundação da Casa Popular, que passaram a financiar a política habitacional a partir de 1930, de maneira um pouco tímida até 1937 e de forma mais efetiva após esta data, quando, com o decreto 1.749 ficaram autorizadas a criação de carteiras prediais, redução da taxa de juros de $8 \%$ para $6 \%$ e ampliação dos prazos de pagamento. A medida, no entendimento de Bonduki (2004), visava por um lado proporcionar o acesso à habitação às classes de

17 O conceito de mundo comum foi elaborado por Arendt (2008), e será aprofundado no terceiro capítulo desta dissertação. 
renda mais baixa e por outro, destinar recursos da previdência às camadas de renda mais alta por meio da rentabilidade superior com os títulos da dívida pública. Além disso, o autor trata de uma disputa por recursos públicos entre os voltados para habitação de interesse social e os voltados para promoção de habitação de alto luxo, disputa que permanece na raiz da política habitacional até os dias de hoje. ${ }^{18}$ As unidades habitacionais eram ocupadas por moradores via aluguel, concessão de crédito para construção em terreno próprio ou empréstimos hipotecários. Bonduki (2004) afirma que os IAPs trabalhavam no sentido de financiar ou alugar moradias abaixo do custo, sem condições de manter o próprio instituto, o que configura populismo e não política social.

Esta política foi realizada durante o Estado Novo. Era voltada para interesses coorporativos e excluiu grande parcela da população. Os IAPs e a Fundação da Casa Popular produziram cerca de 140 mil unidades habitacionais (quando a população do país era de 44,9 milhões de habitantes), e sua grande contribuição foi na verdade qualitativa, definindo novas tipologias de ocupação do espaço e urbanísticas, de viés modernista. A ocupação principal nas grandes cidades, que concentravam pelo menos 8,7 milhões de moradores, continuava a acontecer de forma irregular e sem intervenção do Estado nas periferias em que predominou o auto-empreendimento da casa própria.

A grande inovação da experiência da Fundação Casa Popular e dos Institutos de Aposentadorias e Pensões foi, portanto, não quantitativa, mas qualitativa. Foi neste "laboratório" que elementos da arquitetura moderna foram introduzidos e disseminados no Brasil, como a intensificação da industrialização da construção civil, a inovação formal de projetos e materiais e a busca da funcionalidade, como analisou Maricato (1984).

A opção pela habitação social multifamiliar no Brasil estava na busca por métodos de produção em grande escala. A indústria da construção civil incorporou tecnologias de construção inovadoras, a uniformidade do projeto de unidades habitacionais, a padronização dos blocos e revestimentos. Os urbanistas, por seu lado, buscavam a racionalização do traçado urbanístico. No horizonte dos arquitetos estava

\footnotetext{
${ }^{18}$ Maricato (1984) analisa a política habitacional e conclui que a disputa por uma demanda melhor remunerada é uma de suas características mais importantes.
} 
subjacente o desejo de modernizar o país, a roda motora que do progresso, presente na pauta das decisões políticas e no nosso universo de idéias. Esta pujança de idéias, projetos, obras, era paralela a um processo de urbanização bastante menos planejado em muitas periferias de grandes cidades. Além disso, os exercícios de uso do espaço pelos traços modernos não foram imunes a críticas, como Bonduki (2004) ao demonstrar a apropriação privada de espaços destinados ao coletivo.

A forma de atuação do espaço do movimento moderno na arquitetura também sofreu muitas revisões e críticas, como o movimento Team 10. Nesta crítica, estava subjacente certo caráter decadente do progresso. A permanência de um conhecimento e vivências suplantadas pelo novo nos interstícios da história é uma das questões da modernidade, sobre a qual muitos pensadores se debruçaram, sobretudo os da Teoria Crítica, que estiveram às voltas com o facismo e o nazismo, como Benjamin (1996) e Adorno (1994).

Voltada às matrizes econômicas e sociais brasileiras, esta tese foi apropriada por grandes pensadores sociais, como Prado Jr (1999) e Oliveira (2003). As formas de geração do valor e de acumulação do capital nos países que têm inserção periférica na economia mundial preterem parte da população. A acumulação ampliada do capital residiu até recentemente em grandes lucros em produções que eram restritas. A expansão do consumo a populações que viviam no "atraso" é um fenômeno recente e pode revelar uma nova orientação da economia mundial, no sentido da financeirização.

Do ponto de vista da estrutura política, até os anos 2000 a organização política era necessariamente excludente. A forma política presente na Era Vargas, por exemplo, estava ancorada na organização coorporativa, que é excludente. Eram "assistidos" aqueles que estavam no projeto político de Vargas: os trabalhadores. As Constituições da Era Vargas orientaram-se para atender a oligarquias e aos trabalhadores, e associar direitos aos vínculos trabalhistas. A Constituição de 1934 tinha características liberais, como a liberdade de crença e de reunião e manifestação, atendendo aos interesses das oligarquias, ao mesmo tempo que instituiu direitos sociais (como o direito à educação, à assistência social para famílias numerosos), direitos civis (voto para as mulheres e maiores de 18 anos) e direitos trabalhistas (jornada de 40 horas semanais, direito ao 
repouso semanal, férias anuais e o reconhecimento de sindicatos). Na Constituição de 1937 o poder político se centralizou e os sindicatos passaram a ser atrelados ao Estado. O Estado passou a garantir direitos sociais aos trabalhadores, associando direito ao trabalho, num processo que Santos (1979) chamou de "cidadania regulada".

A política de habitação é parte da cidadania regulada. A habitação era voltada para o trabalhador, identificado como quem está dentro da ordem e quem tem carteira de trabalho. No entanto, não havia (e não há) trabalho regulado para todos, pois a economia organiza-se sem esta universalidade. A habitação de interesse social, para este trabalhador, era baseada na padronização das unidades, no incentivo à convivência das famílias nas áreas coletivas, supondo que todas as famílias tivessem os mesmos valores, sob a visão de igualdade da condição de cidadania dos trabalhadores. Esta política habitacional, entretanto, teve um forte aspecto de "laboratório", pois não se universalizou sequer entre os trabalhadores regulados. Entre os trabalhadores "sem carteira de trabalho", as soluções eram ainda mais "domésticas", como o autoempreendimento da casa própria.

Já em 1957 ficou evidente o caráter restrito da política habitacional. Levantamento realizado pela Sagmacs - Sociedade de Análises Gráficas e Mecanográficas Aplicadas aos Complexos Sociais - naquele ano revelou a existência de 141 núcleos de favelas, totalizando 8,5 mil barracos e 50 mil pessoas. Já na década de 1940 o auto-empreendimento da casa própria era uma das principais formas de provisão de moradia em São Paulo.

Em 1964, com o Golpe Militar, foi criado o SFH - Sistema Financeiro de Habitação e o BNH - Banco Nacional de Habitação, com a Lei 4.380, de 21/08/1964. Com investimentos compulsórios do FGTS - Fundo de Garantia por Tempo de Serviço e em parte voluntária do SBPE - Sistema Brasileiro de Poupança e Empréstimo-, foram financiadas habitações, saneamento básico e infra-estrutura urbanas. O SFH financiou 4,8 milhões de habitações entre 1964 e 1986, quando foi extinto (praticamente 25\% do número total). Um terço desta produção foi dedicada à moradia para trabalhadores que recebiam até dois salários mínimos. A política do BNH destinava-se à habitação de interesse social (população de até 3 salários mínimos), que era provida pelas 
Companhias Municipais de Habitação - as COHABs, à habitação para as classes médias da população (de seis a dez salários mínimos) e à habitação para a população com renda superior a dez salários mínimos. A política do SFH financiou a consolidação de um mercado de construção civil no Brasil, atendendo a interesses de empresários e ao mesmo tempo servindo de moeda de troca de política clientelista para os políticos que trocavam casas por votos.

A política habitacional onerava os salários em $8 \%$, mas não os investimentos das empresas privadas. Além disso, a instituição do fundo de garantia por tempo de serviço criou uma conhecida fórmula de empresários e trabalhadores para ajustes de sazonalidade econômica: as indenizações compulsórias. A construção civil não estava no cerne do crescimento econômico durante os primeiros anos da ditadura militar tanto quanto a produção de bens de consumo e a indústria automobilística. A construção civil criava empregos pouco qualificados e a sua industrialização, que teve um boom nas décadas anteriores, passou a se tornar mais lenta. Bolaffi (1982) O avalia que se a economia tivesse se assentado sobre a produção de habitação popular o crescimento do país seria mais duradouro, ainda que mais lento.

A lenta industrialização da construção civil deu forma aos conjuntos habitacionais promovidos pelas Companhias de Habitação Municipal ${ }^{19}$, executoras do PLANHAP - Plano Nacional de Habitação Popular. A lenta industrialização da construção civil resultou de diversos fatores, entre eles a manutenção de uma força de trabalho pouco qualificada (geralmente formada por trabalhadores migrantes de regiões de menor desenvolvimento urbano para as grandes cidades) e mal remunerada, o que barateava os custos da produção para o empresariado da construção civil. Além disso, a implantação de tecnologias inovadoras nos canteiros de obra implicaria em ampliação da dependência do setor de construção civil brasileiro às indústrias americanas, responsáveis pela transferência desta tecnologia.

A face do $\mathrm{BNH}$ nas cidades eram as $\mathrm{COHABs,} \mathrm{que} \mathrm{se} \mathrm{mantiveram} \mathrm{em} \mathrm{várias}$ cidades mesmo após o colapso do SFH, como no caso da COHAB São Paulo. A

\footnotetext{
${ }^{19}$ A este respeito, ver Magnavita (1994).
} 
COHAB SP é uma sociedade anônima de economia mista, constituída de acordo à Lei Municipal no 6738/65 e alterada pela lei 8310/75. De sua criação até 1992 produziu 142.000 unidades habitacionais. Até 1981 seu estoque de terras estava na zona leste ( $93 \%$ na zona leste, das quais $24,5 \%$ estavam ocupadas, sendo que destes $99 \%$ estavam nos distritos de Guaianases e Itaquera). As terras eram localizadas nas áreas periféricas devido ao seu baixo custo em relação às áreas centrais. $\mathrm{O}$ grande volume de terras na zona leste da cidade explica-se por suas características geomorfológicas, por serem terras menos acidentadas, porém com níveis de resistência do solo que acarretam mais custos nas fundações. ${ }^{20}$ Esta expansão foi amparada pelas modificações no Código de Obras, em 1975, às condições que regulamentam os artigos 516, 522, 523 e 565 da Lei 8266.

Ao mesmo tempo em que transformava a face das cidades, verticalizando os centros e criando infra-estrutura urbana nestas regiões, a política do SFH, voltada para as camadas médias da população, foi acompanhada de um crescimento acintoso das favelas nas grandes capitais. Em São Paulo, Maricato (1996) analisou a Lei .6.766 de 1979 avaliando que ao criar mecanismos restritivos à legalização dos loteamentos (lembremos que a auto-empreendimento da casa própria era a forma de provisão de moradia quantitativamente mais significativa no período) a Lei implicou num crescimento desmesurado do número de favelas nas cidades. Durante os anos 1980 a população cresceu acima dos $70 \%$ do total. As cidades se periferizavam. ${ }^{21}$

A experiência do BNH desdobrou-se em uma série de atividades distantes do projeto de provisão habitacional. Além das negociações ilícitas com os recursos públicos, que são citadas por Bolaffi (1982), os recursos do fundo de garantia do

\footnotetext{
${ }^{20}$ Dado de Caio Boucinhas, em entrevista à autora.

21 "Apenas para dar alguns exemplos, 49,3\% das favelas de São Paulo têm alguma parte localizada em beira de córrego, 32,2\% estão sujeitas a enchentes, 29,3\% localizam-se em terrenos com declividade acentuada, $24,2 \%$ estão em terrenos que apresentam erosão acentuada e 0,9\% estão em terrenos de depósitos de lixo ou aterro sanitário. Do total, $65 \%$ estão situadas em área pública e $9 \%$ em terrenos de propriedade mista, ou seja, pública e privada. Estes dados são de 1987, quando o número de favelas era de aproximadamente 1.600 núcleos onde moravam aproximadamente 8\% da população. Em 1993 essa proporção é de 19,8\%." Maricato (1996, p. 58).
} 
conjunto dos trabalhadores brasileiros foi revertido para a construção civil, cuja atuação pode ser questionada em relação à geração de empregos duradouros, bem remunerados e estruturados do ponto de vista da qualificação dos trabalhadores, para a produção de habitação voltada para uma parte da população, de rendas médias, e não para o conjunto dos cidadãos brasileiros. Foi, pois, uma política de concentração de renda e de concentração de serviços urbanos em determinadas áreas das grandes cidades, contribuindo para os processos de segregação sócio-espacial. Do ponto de vista da inovação tecnológica os avanços estavam restritos à indústria e atrelados ao mercado internacional, não sendo apropriados pelas práticas de construção civil do país.

\section{Auto-Empreendimento da Casa Própria e periferização}

As habitações produzidas pelo Banco Nacional de Habitação foram voltadas em sua maioria para as camadas médias da população. O conjunto de trabalhadores pouco qualificados das grandes cidades, cujos recursos eram insuficientes para acessar o mercado privado ou os programas habitacionais, lançou mão do auto-empreendimento da casa própria para prover sua habitação, via de regra realizado nas regiões periféricas das grandes cidades, sem infra-estrutura urbana ou serviços públicos. Os problemas urbanos resultantes deste processo, como os altos custos de implantação de serviços básicos nas regiões distantes do centro, foram percebidos e descritos pelos analistas urbanos desde os seus primórdios. O fenômeno de periferização da cidade, com suas raízes nas decisões urbanas e das políticas habitacionais desde o início do século XX, intensificou-se ao longo dos anos 1970 e 1980, e pode ser analisado como resultante das dinâmicas de crescimento engrendradas pelos grupos ligados ao poder econômico no país, baseadas na manutenção de baixos salários para os trabalhadores e altos lucros para os grandes empresários, como os empresários da construção civil. Outro fator de ampliação dos lucros para os empresários e restrição do acesso à cidade para os trabalhadores foi o aumento do preço do solo urbano. O solo urbano das regiões centrais das grandes cidades encareceu na medida em que as regiões distantes do centro iam sendo ocupadas, num processo especulativo. O solo urbano nas regiões centrais 
concentra, historicamente, o monopólio das atividades produtivas geradoras de renda, o que contribui para o processo especulativo. Trata-se, ademais, da parcela do solo urbano que recebe investimentos públicos de melhoria (como abertura de vias, de metrô, de saneamento). Embora os impostos urbanos tenham sido historicamente equivalentes, a apropriação dos benefícios dos impostos foi desigual. Enquanto os proprietários das áreas centrais receberam benfeitorias ao solo urbano sem a contrapartida dos impostos, o mesmo não acontecia com os bairros da periferia. Para os trabalhadores que produziram suas habitações o ônus da habitação é mantido no seu orçamento, retirando a provisão da habitação da cesta de valores que deveriam ser pagos por seu salário e mantêm-no achatado. ${ }^{22}$ Também do ponto de vista tributário o ônus era repassado ao trabalhador cujo acesso à propriedade era restrito:

\begin{abstract}
"A política fundiária no Brasil, cuja principal característica é a ausência de impostos significativos sobre a propriedade imobiliária, se transforma assim no principal mecanismo por meio do qual os capitais provenientes da arrecadação tributária são transferidos aos proprietários de casas e terrenos. Enquanto esse processo acelera a concentração e a acumulação de renda gerada pela nação nos bolsos da minoria que possui os capitais necessários para adquirir o bilhete premiado da loteria imobiliária, as cidades do país são descapitalizadas e empobrecidas." ${ }^{23}$
\end{abstract}

A tese de Singer (1982), que seria recuperada por Villaça (2001) anos mais tarde, nos dá conta de que a cidade cresce a partir da dinâmica do capitalismo, que cria localizações (monopólios do uso do espaço) e diferenciações internas, geradoras de segregação. Ao estudar as relações entre os interesses imobiliários, industriais, comerciais e os resultados viários em seis capitais brasileiras (Rio de Janeiro, São Paulo, Belo Horizonte, Porto Alegre, Salvador e Recife), Villaça (2001) apontou que as semelhanças encontradas revelam cidades cujos bairros detêm características arquitetônicas, sociais e econômicas relativamente homogêneas, relacionadas entre si a

${ }^{22}$ Este fenômeno foi conceituado por Oliveira (2003) como supertrabalho

${ }^{23}$ Bolaffi (1982). A conceituação de Singer citada aqui nos remete ao fato de que o espaço não é um meio de produção, mas está ligado à reprodução da dinâmica urbana que estrutura as relações capitalistas na cidade. 
partir da predominância dos interesses econômicos de consumo, definidores da circulação e conseqüentemente dos investimentos viários necessários às circulações preponderantes. Manifesta-se nas cidades estudadas a segregação sócio-espacial por interesses dominantes que tendem a crescer numa mesma direção, próximas às suas necessidades de consumo, serviços e lazer. O sistema viário corresponde, nesta lógica, às necessidades das burguesias, relegando as classes trabalhadoras a necessidade de um deslocamento mais longo.

\begin{abstract}
"As camadas de mais alta renda controlam a produção do espaço urbano por meio do controle de três mecanismos: um de natureza econômica - o mercado, no caso, fundamentalmente o mercado imobiliário; outro de natureza política: o controle do Estado e, finalmente, através da ideologia.”Villaça ( 2001, p. 335)
\end{abstract}

A dinâmica do espaço estrutura o uso do tempo pelos diversos grupos sociais que habitam a cidade. São os grupos que habitam as regiões mais distantes e pouco servidas que necessitam de mais tempo para se deslocar em suas atividades cotidianas, sejam de trabalho ou de lazer. O uso do tempo revela uma dimensão da relação de poder que o espaço produz, pois o uso do tempo está associado às possibilidades de lazer e de estudos no chamado tempo livre, que são menores para todos os que precisam de maior tempo para se deslocar, em função da estruturação dos sistemas viários e de transportes. As dinâmicas de uso da cidade e do tempo estão em tensão o tempo todo, evidenciando que a cidade segregada é uma cidade de disputas de poder desiguais. Uma das disputas urbanas é a disputa por localizações, definidas pelo acesso aos recursos urbanos socialmente construídos, em geral, absorvidos e usados pelos que detém maior poder.

"É através da relação dialética entre tempo e espaço - na qual o tempo aparece como tempo de deslocamento do ser humano - que o tempo deixa de ser um conceito abstrato, uma categoria metafísica que paira para fora e além do controle dos homens. A produção do espaço aparece, então, como forma de controle do tempo, por apropriar-se diferencialmente dos frutos do trabalho envolvido nessa produção" (idem, p. 359)

No caso histórico do auto-empreendimento da casa própria, dos anos 1960 até a 
aprovação do Estatuto da Cidade, a dinâmica, descrita por analistas, dizia respeito ao seguinte jogo: participavam cinco agentes: o empreendedor do loteamento (loteador), o corretor, os compradores dos lotes (moradores) e o Estado. O proprietário do terreno trazia a posse do terreno, apenas. O projeto, a aprovação, as obras de terraplanagem, arruamento e benfeitorias ficavam a cargo do loteador. A fixação da prestação era feita a partir da disponibilidade de pagamento dos moradores. $\mathrm{O}$ corretor era um intermediador, quem se encarregava da divulgação e da venda. Sua remuneração era uma comissão dos lotes vendidos. O Estado tinha um papel de financiador, implantador e gestor dos bens coletivos. Bonduki e Rolnik (1982) analisaram o papel do Estado como financiador de serviços estratégicas da cidade (como energia e transportes, e empresas produtivas) mais do que como agente do desenvolvimento da reprodução da força de trabalho. O papel do Estado foi maior, no caso da provisão habitacional, que é um dos elementos da reprodução da força de trabalho, como ator que garantiu o suporte legal para a abertura dos lotes em condições físicas mínimas.

O contexto é um período da formação de um amplo exército industrial de reserva aliado a uma população controlada politicamente - ditadura militar - situação em que os salários ficaram abaixo do custo de sua reprodução. E o trabalhador se identifica como um proprietário ao conseguir, ao custo do supertrabalho e da superexploração, a casa própria.

$\mathrm{O} \mathrm{BNH}$, por outro lado, com moradias financiadas por cooperativas habitacionais, não ofereceu moradias aos estratos mais baixos da população, usando estritamente da lógica mercantil: suas casas eram pagas com trabalho pago, seguindo as normas do código de obras, obedecendo à legislação municipal e oferecendo um mínimo de infra-estrutura. Destinou-se às camadas médias da população. Não houve subsídios para a construção de habitação para as camadas de renda mais baixa da população.

Na década de 1980 agravou-se a crise habitacional. Os aluguéis subiram 500\% entre 1981 e 1986, e as classes médias da população começaram a disputar terreno com as classes baixas. ${ }^{24}$ As favelas iam ocupando os terrenos vazios. As periferias mais 
distantes iam se consolidando.

A reação da cidade de São Paulo às favelas foi ambígua ao longo dos anos. ${ }^{25} \mathrm{Se}$, por um lado, o mercado imobiliário voltava-se primordialmente para as camadas mais consolidadas da população, aquelas atreladas ao desenvolvimento da economia ligada à economia internacional e, nestes termos, assegurada pela legislação trabalhista, um conjunto de trabalhadores pobres em seus empregos e expedientes cada vez mais precários $^{26}$ ligava-se ao solo urbano de forma precária e irregular.

O poder público, por sua vez, ofereceu tratamentos distintos às diferentes situações de habitação. No caso das favelas houve ao longo do tempo desocupações violentas seguidas de reurbanização das áreas. Ao longo das décadas que se seguiram a 1980 desocupações violentas foram realizadas em processos em que os moradores foram tratados de forma arbitrária $^{27}$. O que vige na Lei ainda hoje é a Lei de Zoneamento de 1972, em que os assentamentos são definidos como subnoramais. Na prática, agenciamentos e negociações são realizados entre moradores e funcionários e políticos encarregados da aplicação da norma. ${ }^{28}$

Por outro lado, no caso do auto-empreendimento da casa própria assistiu-se à recorrentes anistias, que tiveram um impacto político amplo, como a lei sobre a

25 Rolnik (1997) lembra que há interpretações distintas de diversos matizes da irregularidade. Assim, o auto-empreendimento da casa própria difere da favela, pois, embora sejam ambas irregulares, a favela tem em sua natureza apenas o critério da utilização, enquanto a casa própria auto construída está embasada pela aquisição, base fundamental da noção de propriedade.

26 A literatura sobre precarização do trabalho e globalização é ampla. Recentemente a interpretação do fenômeno vêm ganhando abordagem urbana como em Telles (2006).

27 São paradigmáticos os trabalhos de Fix (2001) sobre a desocupação da favela às margens do córrego Águas Espraidas para dar lugar à avenida e o trabalho de Alves (2006) sobre a desocupação do Jardim São Carlos, em Guaianases.. Para uma história das favelas no cenário carioca ver Valladares (2005).

28 O trabalho de Pulhez (2007) destaca as formas de tratamento dadas às favelas ao longo do tempo nas cidades brasileiras, ressaltando a visão da favela como uma expressão cultural popular (anos 1960), como uma expressão da participação social (anos 1970 e 1980) à fragmentação social com a violência urbana (anos 1990 a 2000). 
"oficialização de logradouros" , anistiando em massa as ocupações irregulares. ${ }^{29}$

Do ponto de vista do planejamento urbano, os órgãos criados para regularizar a questão urbana não tinham recursos ou meios legais para realização dos planos, como era o caso da Emurb - Empresa Municipal de Urbanização, criada em 1972 para adquirir terrenos em valorização para a instalação de metrô e devolvê-las à população com os serviços públicos instalados.

O crescimento da cidade via periferização é de interesse dos especuladores imobiliários, pois engendra uma demanda por terrenos vazios e uma extensa transformação de glebas rurais em urbanas, elevando o preço dos terrenos. A verticalização das áreas centrais, por outro lado, concentra os investimentos e lucros imobiliários na região central. Em 1997, com a instituição do Sistema Financeiro Imobiliário (SFI) pela Lei 9.514 (que dispõe sobre o sistema financeiro imobiliário), o sistema financeiro passou a reger o mercado imobiliário, acentuando o caráter altamente especulativo da provisão habitacional.

A forma de urbanização de São Paulo - via auto-empreendimento da casa própria, periferização e favelização - é um movimento coerente à expansão do mercado imobiliário por toda a cidade. O Estado esteve presente o tempo todo, orientando os recursos para a provisão habitacional para uma determinada classe e investindo em obras viárias e serviços públicos em áreas centrais. Desta forma, o papel do Estado, em lugar de compensar o processo de segregação sócio-espacial, contribuiu para intensificá-lo.

A produção de habitação de interesse social nos confins da periferia, como

29 O prefeito era Jânio Quadros. Jânio Quadros venceu como governador em 1955 ampliando os serviços de água para a periferia. Consolidou, com essa política, um primeiro anel de loteamentos. "Este pacto territorial esboçado desde os anos 30, mas definido mais claramente no contexto da redemocratização e do populismo, nunca mais foi desmontado. Nem mesmo durante os anos de ditadura, o esquema foi interrompido: novas regularizações em massa foram decretadas em 1962 e em 1968; as sociedades amigos de bairro (SAB's) continuaram a ser recebidas nos gabinetes de prefeitos, vereadores $e$ secretários. Durante o período de 1969 a 1988, em que não houve eleições para prefeito, a Câmara dos Vereadores transformou-se no grande canal para as demandas dos bairros por serviços, tecendo redes políticas que iam de bairros a secretários, assessores e funcionários municipais. E assim, camadas da periferia foram sendo seletivamente incorporadas à cidade e novas fronteiras se constituíram." Rolnik (1997) 
veremos, não apenas atendeu aos interesses das grandes empreiteiras como também cedeu espaço à especulação imobiliária nas regiões centrais. Formou-se um mercado de habitação que atende às camadas médias e altas inscritas na cidade, ao mesmo tempo em que se gerencia a pobreza seja por meio de uma política ambígua em relação às favelas (das arbitrárias remoções às práticas de reurbanização), seja por meio de uma política de habitação social de resultados discutíveis (os conjuntos habitacionais), ou, ainda, através dos controversos mutirões. ${ }^{30}$

30 Os mutirões foram uma política encarada de forma bastante controversa dentro dos estudos urbanos. Uma das principais críticas aos mutirões vê nesta forma de provisão habitacional uma exploração do tempo de trabalho dos mutirantes, como em Oliveira (2003). 


\section{Capítulo II - Um capítulo da política habitacional em São Paulo: o distrito de Cidade Tiradentes}

Neste capítulo será feito um breve resumo da política da COHAB-SP desde 1960 até os anos 2000, mostrando sua ênfase na produção de conjuntos habitacionais de grandes proporções em terrenos baratos, via de regra em regiões periféricas da cidade. A política de habitação de interesse social após o fim do Sistema Financeiro de Habitação, como foi descrito no primeiro capítulo, passou a ser gerenciada por órgãos municipais, como a COHAB-SP. A abordagem à produção histórica da COHAB-SP evidencia o papel da política habitacional da COHAB-SP na intensificação do processo de segregação sócio espacial, produzindo bairros que concentram populações afastadas dos empregos e de muitos serviços que estão presentes na região central. Do ponto de vista dos grupos ligados às grandes empresas da construção civil a produção desta política resultou na manutenção ou ampliação de seus lucros. Do ponto de vista do mercado imobiliário, esta política implicou no acirramento da especulação imobiliária nos bairros centrais.

O recorte para o aprofundamento desta análise nesta dissertação é o conjunto habitacional Santa Etelvina, produzido pela COHAB-SP no final dos anos 1970 e durante toda a década de 1980. O capítulo contempla um breve histórico deste conjunto habitacional, bem como alguns indicadores sócio-econômicos para caracterizar os moradores, explicitando a segregação sócio-espacial.

O objetivo central deste capítulo é evidenciar a política da habitação de interesse social como produtora e reprodutora de desigualdades sócio-econômicas e como agente de segregação sócio-espacial. 


\section{Atuação da COHAB-SP}

A Companhia de Habitação de São Paulo foi criada em 1965, como parte do Sistema Financeiro Habitacional. Entre 1965 e 2000 a COHAB-SP construiu 134.900 unidades, sendo 55 conjuntos de Habitação de Interesse Social - HIS, que ocupam uma área de 22.285.468 $\mathrm{m}^{2}$ e abrigam uma população de 655.865 pessoas.

O maior estoque de terras foi comprado entre as gestões dos prefeitos Olavo Setúbal (1976-1978) e Reynaldo de Barros (1979-1981). A maior parte das terras foi adquirida na Zona Leste (68\%), em grandes glebas. A expansão das construções se deu no final dos anos 1970 e no início dos anos 1980.

Embora significativa em termos absolutos, em termos relativos a produção da COHAB-SP entre 1966 e 1985 era reduzida, como observa Sachs (1999, p.22), em relação à população na região metropolitana de São Paulo, que saltou, entre 1960 e 1985, de 4,8 para 15,1 milhões de habitantes.

Em 1966 foi criado o Departamento de Habitação e Trabalho - HABI. Entre 1966 e 1970, como mostra Constantino (2007), HABI atuou principalmente no atendimento a famílias residentes de favelas, por meio de compras de casas em conjuntos da COHAB-SP, compras de terrenos e construção de casas, aluguéis de casas ou quartos ou destinação de recursos para retorno das famílias ao local de origem.

Entre 1971 e 1975 HABI realizou pesquisas em cortiços e continuou atuando na remoção de famílias de favelas.

Entre 1979 e 1982 o atendimento passou a priorizar a fixação da população no local da moradia e a resolução da provisão de moradia. Foram criados programas como PROMORAR e PROFAVELA. 
Em 1986, HABI - Superintendência de Habitação Popular foi transferida para a SEHAB - Secretaria de Habitação. Na gestão Mário Covas (1983 a 1985) intensificouse o processo construtivo por empreiteiras (Constantino, 2007).

Como citado no primeiro capítulo, os anos 1980 foram marcados pela emergência de movimentos sociais, ligados ao crescimento das periferias via autoempreendimento da casa própria. Nos bairros periféricos, surgiram movimentos em torno de melhores condições de urbanização e de direitos sociais básicos. Ao mesmo tempo, o movimento de moradia era organizado, revelando a demanda por habitação nas grandes cidades e buscando estratégias de enfrentamento junto ao poder público. O movimento de moradia estruturou-se em diversos bairros da cidade de São Paulo, inclusive em Cidade Tiradentes, revelando uma demanda por habitação superior à oferta pelo Estado. Durante a pesquisa em campo, houve citações do movimento por moradia no bairro, estruturado em torno da questão das ocupações em áreas do poder público e das tentativas de desocupação por parte do governo municipal. Não apenas em Cidade Tiradentes, mas em bairros da periferia e na região central o movimento de moradia organizou-se e buscou estratégias de negociação com o poder público.

Na gestão Erundina (1989-1992) os movimentos de moradia interferiram diretamente na política para habitação, que foi considerada como prioritária pelo governo municipal. Nesta época os pressupostos da Política Habitacional foram:

a. "Direito à moradia e à cidade, reconhecendo a existência
da cidade real (dos assentamentos precários como favelas,
loteamentos irregulares, cortiços e coabitações);
b. Direito à arquitetura (e engenharia) e respeito ao meio
ambiente;
D. Direito à cidadania e participação popular na formação e
implementação de Programas e Projetos e estímulo à auto-
gestão;
Redução de curtos sem perda de qualidade, administração
ágil e eficiente" Constantino (2007, p.33)

Tratou-se de um movimento de busca por qualidade na habitação de interesse social, formado em tessitura com quem estava na lida cotidiana com a 
questão da habitação: os movimentos de moradia. Neste processo foram criados fóruns de debate e criação de alternativas; foram realizadas avaliações das ações em andamento (como no caso da COHAB Cidade Tiradentes) e foram desenvolvidas as experiências dos mutirões. ${ }^{31}$

Não obstante as tentativas de implementação de habitação de interesse social de forma democrática dando abertura à participação dos moradores, a atuação da COHAB-SP durante as gestões posteriores retomou a proposta de construção de conjuntos habitacionais via grandes empreiteiras em terrenos periféricos.

"Logo que os conjuntos habitacionais foram sendo entregues para as famílias de baixa renda na década de 1970 e 1980, ficou evidente que se tratava de uma continuidade da segregação sócioespacial que construiu os processo de apartação territorial entre ricos e pobres que estruturou, desde sempre, o crescimento da cidade de São Paulo em seus períodos de expansão ao longo do século XX, notadamente nas décadas de 1950 e 1960.As COHABs foram construídas em meio a loteamentos periféricos precários clandestinos, e, no caso da COHAB Cidade Tiradentes, fora dos territórios urbanizados, em áreas distantes dos empregos, escolas, hospitais, pólos comerciais, espaços públicos, equipamentos culturais, lugares para o encontro, o convívio, as trocas sociais, enfim, de todos os atributos que efetivam uma área urbanizada como cidade." Nakano (2002, p.95).

As principais críticas feitas à política da $\mathrm{COHAB}-\mathrm{SP}$ dizem respeito à aquisição de terrenos em locais periféricos, como defendem Nakano (2002) e Maricato (1997), à padronização das tipologias habitacionais, como em Slomiasnki (2002), à ausência de participação popular, aos vínculos com a política de clientelismo e de favor, e, afinal, à despolitização da questão da moradia.

Autores como Nakano (2002) defendem a idéia de que a opção pela construção de conjuntos habitacionais em terrenos periféricos da cidade abriu espaço para o que ele chamou de "urbanização clandestina":

\footnotetext{
${ }^{31}$ Para uma análise dos mutirões em São Paulo ver Carvalho (2004).
} 
“A construção de conjuntos habitacionais em locais periféricos inaugura um círculo vicioso pois cria acessibilidades físicas e expande as redes de serviços coletivos abrindo frentes de especulação viabilizando a urbanização clandestina dada a ausência de fiscalização que controlaria a atuação dos agentes que produzem esse tipo de espaço urbano ilegal e irregular." Nakano (2002, p. 97)

É nestes termos que o trabalho de Slomianski (2002) investiga a concentração de terrenos vazios em Cidade Tiradentes e sua destinação. Ela mostra que as ocupações correspondiam, no final dos anos 1990, a 26\% das áreas destinadas à COHAB, 12\% das áreas verdes, e $22 \%$ das áreas públicas vazias.

A abordagem dos dois autores está relacionada ao entendimento de que havia (e ainda há) na cidade uma cisão entre os aspectos legais e os aspectos ilegais da urbanização. O próprio argumento, contudo, revela que, na origem, a urbanização promove situações diversas em relação ao poder público, e que serão tratadas de maneira diversa pelas gestões municipais. As formas de apropriação e uso do espaço são diversas e se orientam num mundo de possibilidades, acessos e restrições. A capacidade de fiscalização do poder público é restrita. O poder público atua com uma legislação rígida que não é cumprida. Os loteamentos nas periferias das grandes cidades muitas vezes são abertos com "vista grossa" (corrupção) dos órgãos fiscalizatórios, e muitas ocupações em terrenos públicos ou privados são levadas a cabo com o apoio de líderes legislativos municipais ou seus assessores. O sentido do poder público, nestes termos, é orientado de forma diferente circunstancialmente. O próprio sentido da urbanização do Estado muitas vezes age na contramão da legalidade. Muitos conjuntos habitacionais em Cidade Tiradentes foram construídos antes mesmo da regularização dos lotes. Os tempos da política executiva nem sempre atendem aos prazos da burocracia legal.

Constantino (2007, p. 49) afirmou que: "em dezembro de 2000 a COHAB tinha 33.493 unidades habitacionais não regularizadas, e, dessas unidades, $81 \%$ estavam nessa situação há 11 anos e 37\% há 15 anos”.

A apropriação do espaço produzido pelo poder público também não é totalmente livre de arbitrariedades. Muitos moradores contemplados com apartamentos produzidos pela COHAB-SP, em diferentes gestões, conquistaram o direito ao financiamento por 51 
suas ligações políticas. Durante a gestão Erundina, a fim de universalizar o acesso, o critério ao financiamento foi o sorteio.

O sentido da urbanização é, portanto, o de produção de situações variáveis entre o que se entende por legalidade e respeito às normas e o que se entende por ilegalidade. Neste campo de relações os agenciamentos entre o poder público e a população são móveis e, em muitos casos, arbitrários, ao sabor do reconhecimento do poder.

Em relação às tipologias, elas se referem diretamente à qualidade de vida dos moradores. A tipologia mais recorrente (96.080 das 134.900 unidades habitacionais) é o "bloco de apartamentos", que têm de 4 a 5 pavimentos em " $\mathrm{H}$ ".

Segundo Constantino (2007, p. 44):

"A pequena distancia entre as lâminas que formam o " $\mathrm{H}$ " em relação à altura dos prédios, prejudica a insolação e a ventilação dos compartimentos inferiores, que têm janelas voltadas para a área interna onde se localiza a caixa de escadas. Isso se agrava com a muito comum geminação entre blocos em "H", que cria fossos em que a iluminação e a ventilação são ainda mais comprometidas.

A ocupação dos térreos por apartamentos implica na redução da privacidade dessas unidades e obriga que se implante, em áreas condominiais externas aos edifícios, equipamentos que são essenciais para seu funcionamento mas que são verdadeiros trambolhos (abrigos de gás, centros de medição, lixeiras, caixas d'água, e ocupam espaços que poderiam ser melhor utilizados para implantação de caminhos, jardins, áreas de lazer, etc. E também não permite a utilização dos terrenos para o abrigo de veículos, tornando necessária a destinação de grandes áreas para estacionamento."

Além destas críticas o autor relata também a existência de 14.000 processos jurídicos por problemas construtivos, como fissuras nas paredes, e falhas nas construções elétricas e hidráulicas.(idem, p. 47). 


\section{Expansão urbana e Conjunto Habitacional Santa Etelvina}

À crescente expansão do auto-empreendimento da casa própria nas periferias da cidade somou-se a provisão de habitação por meio da COHAB-SP. A estratégia da $\mathrm{COHAB}$ era a compra de terrenos baratos, geralmente na periferia da cidade, e a contratação de construtoras com tecnologia defasada em relação ao desenvolvimento da construção civil nos países do capitalismo central, conseqüentemente, um canteiro com relações de trabalho baseadas em baixos salários, pouca qualificação, desperdício e subcontratação de mão-de-obra. Tanto do ponto de vista do processo de trabalho quanto do ponto de vista da cadeia produtiva em questão o processo de construção de habitação de interesse social baseou-se em uma indústria atrasada e sem investimentos em processos inovadores. O desenvolvimento da indústria da construção civil está atrelado ao desenvolvimento industrial brasileiro, em que a regulação Estatal contribuiu para o achatamento de salários e a existência de uma ampla informalidade nas relações trabalhistas. ${ }^{32}$ Somado a isto, a indústria da construção civil pode manter-se atrasada, pois seus lucros decorrem em grande medida do valor da terra, e os preços da terra estão inchados pela especulação imobiliária. ${ }^{33}$

Do ponto de vista do projeto a busca por uma solução cada vez mais barata implicou na construção de apartamentos cada vez menores e prédios em condições de conforto térmico, acústico e lumínico insalubres. Problemas na estrutura dos conjuntos também foram encontrados, como foi relatado em entrevista ao diretor técnico da COHAB durante a gestão Luiza Erundina (1989-1992), Caio Boucinhas. Quando a gestão Erundina assumiu a prefeitura em 1989 o corpo técnico da Secretaria Municipal de Habitação interrompeu as obras no Conjunto Habitacional Santa Etelvina e fez um levantamento das condições estruturais dos prédios. Foram verificadas irregularidades e

\footnotetext{
32 Oliveira (2003, p.60). "a expansão do capitalismo no Brasil se dá introduzindo relações novas no arcaico e reproduzindo relações arcaicas no novo". Como o autor ressalta, a consolidação das leis trabalhistas - CLT - criou um enorme exército industrial de reserva, achatando os salários e, desta forma, mantendo altos os lucros do empresariado.

${ }^{33}$ Maricato (1984).
} 
centenas de processos contra as construtoras permanecem em andamento até os dias atuais.

O processo de construção do conjunto habitacional Santa Etelvina, o maior da América Latina, significou a construção de tipologias habitacionais na extrema periferia leste, em terreno arenoso, a um custo de terraplenagem altíssimo.
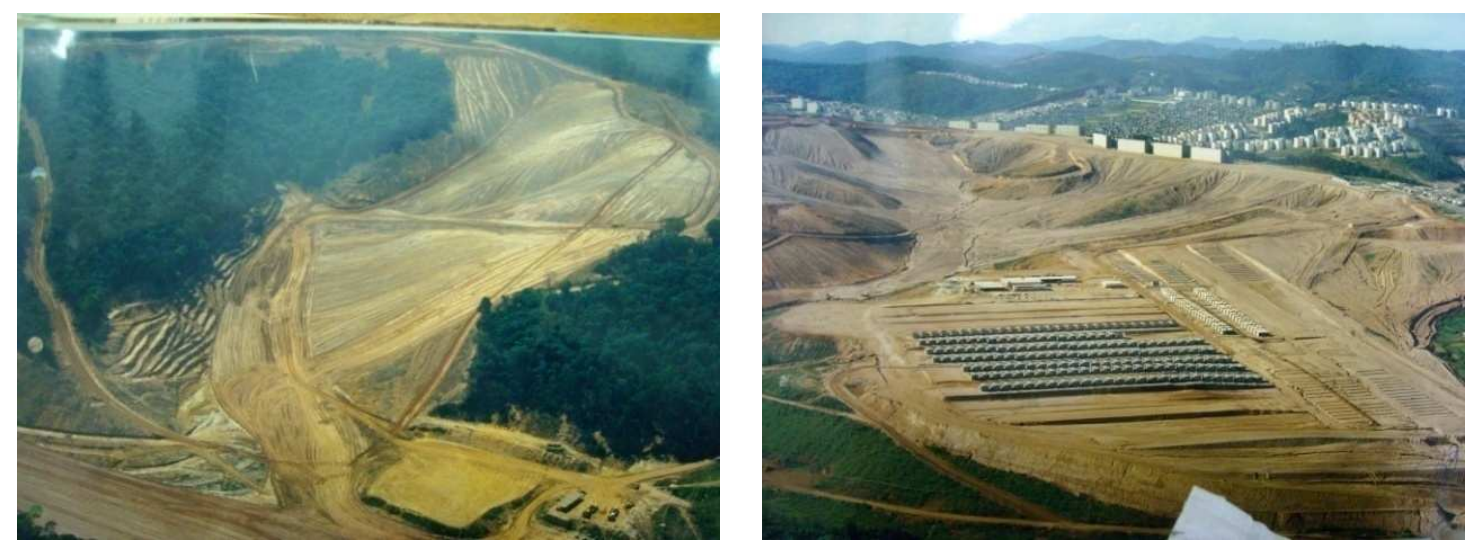

Fotos: arquivo $\mathrm{COHAB}-\mathrm{SP}$

Em entrevista, Caio Boucinhas, diretor de habitação da $\mathrm{COHAB}$ na gestão Luiza Erundina, a gestão seguinte ao início das obras na Cidade Tiradentes, afirmou que, em função dos custos com a terraplenagem e as fundações, o custo de um apartamento na Cidade Tiradentes equivalia ao custo de um apartamento em Perdizes, um bairro com estrutura urbana e ambiente construído bastante valorizados. Na gestão Erundina realizou-se um levantamento dos custos da produção da moradia e dos processos construtivos: foi realizado o "Dossiê: A Verdade Sobre a COHAB", segundo o qual foram movimentados $12 \mathrm{~m}^{3}$ de terra para cada $\mathrm{m}^{2}$ de superfície, citado por Constantino (2007, p. 42). Inúmeros prédios foram considerados inadequados do ponto de vista da qualidade dos materiais e do processo construtivo. Na gestão Erundina procedeu-se a um levantamento dos custos da produção da moradia e dos processos construtivos. Inúmeros prédios foram considerados inadequados do ponto de vista da qualidade dos materiais e do processo construtivo. Caio Boucinhas trabalhou em uma construtora antes de trabalhar na e seu primeiro contato com a Cidade Tiradentes data do momento em que se fazia a terraplenagem do terreno. Em seu depoimento fica clara a inadequação construtiva do conjunto: 
"Essa empresa tinha obras em Santa Etelvina... eu ia lá e via aquela coisa caótica, terrivel, aquele movimento de terra. Eles falavam que tinha corte de 30 metros e aterros de 30 metros para fazer platôs para os projetos padrão da COHAB, que a gente chamava eram os "carimbos $H$ ", que são aquelas lâminas com escada aqui. Então, assim, era um carimbo. Quando a Luiza Erundina foi eleita eu fui trabalhar na COHAB. Eu fui superintendente de obras, o Santanna era diretor técnico. A gente constatou que o governo federal boicotava recursos para uma gestão petista na cidade de São Paulo. E tinha em andamento vinte e tantas mil unidades habitacionais em São Paulo. Na cidade Tiradentes se não me engano eram 17 ou 18 mil. E assim, local de acesso dificílimo, e já aquela tragédia sócio-ambiental que a gente percebia lá. Transporte deficiente, não tinha equipamento público, já era deficiente, e mais de 18 ou 17 mil unidades lá. Dezessete mil famílias sem abastecimento, sem padaria, sem transporte, E a gente começou a ver aqueles platôs, aquela terraplenagem que foi feita. E os platôs que essa fotografia mostra. A drenagem não era feita de forma adequada, então os platôs se desmanchando. A cada chuva aquela erosão enorme, aquele rapinamento de todos os taludes e tal. Então era um quadro meio complicado. E, além disso, os sistemas construtivos em andamento, a gente verificou que tinham coisas que não tinham controle técnico adequado. Por exemplo, alvenaria armada com blocos de concreto, eles estavam fazendo parede estrutural com blocos de nove de espessura. $O$ bloco de nove de espessura ele deixa o furo onde você passa a ferragem e vai gradear, botar aquele concreto plástico não possibilita que você assegure que a concretagem foi feita de cima a baixo. Mesmo que você diminua as fiadas para serem concretadas tem essa dificuldade. Por que é muito pequeno o furo. E parede estrutural a gente sabia que era parede de 19 com bloco de 19, no máximo 15 em alguns casos. Então a gente via que tinha esses problemas. Uma outra firma que estava fazendo pré-moldado a gente quis conhecer o projeto melhor e a gente achou um projeto que não nos parecia seguro, que ia dar uma estabilidade na edificação. A gente procurou, teve uma assessoria do IPT e realmente a gente suspendeu essas obras com alvenaria armada com parede estrutural com bloco de 9. Os empreiteiros reclamavam que já tinham comprado não sei quantos milhões de blocos mas que a gente suspendeu... e claro que as paredes divisórias podiam ser com esse bloco. A empresa de pré-moldados refez o projeto e foi aprovado. (...) Para viabilizar esse projeto padrão o sistema 
construtivo eu podia fazer o que eu queria. O que a minha empresa podia oferecer. Então tinha pré-moldado, tinha alvenaria armada com bloco de concreto, tinha alvenaria armada com bloco de cerâmica, a empresa Seleta, e tinha altinor, aquelas formas deslizantes com a parede concretada. Isso eles fizeram bastante em Jardim Antártica. Eu fui numa reunião à noite lá e achei aquilo uma tragédia sem fim. Um horror você morar lá. As ruas desertas, não tinha local de encontro de pessoas, não tinha nada. (...)”

A alternativa de suspender as obras foi considerada, mas optou-se por mantê-las em virtude da lista de espera que passava de 400 mil famílias:

"Teve uma vistoria com Raquel Rolnik, Ermínia Maricato, para saber se iam ser interrompidas as obras ou não. (...) em cima da pressão da lista de 400 mil pessoas decidiu-se manter as obras. (...)"

O aspecto que mais chama a atenção no depoimento de Caio Boucinhas é forma como os recursos eram geridos. As empreiteiras geriam os recursos públicos, numa clara demonstração de como os interesses privados se apropriam do fundo público. Os recursos públicos eram deslocados para as empreiteiras, que se responsabilizavam sozinhas pelas obras. Os vínculos entre o Estado e o capital privado eram do interesse privado, e não do interesse público:

"Os empreiteiros é que comandavam os recursos da Caixa. O Sistema Financeiro de Habitação, quando ele foi criado, na época da ditadura ele priorizava a classe média, depois teve esses grandes empreendimentos e as grandes empreiteiras tinham lucros fabulosos. As firmas de terraplenagem, imaginem o quanto elas não ganharam com isso. E os córregos, as nascentes eram aterradas. Era um desastre sócio ambiental muito claro, muito visível. E fora o desastre social. (...) Eu lembro de empreiteiro que falava assim, 'ah, precisa mudar tal coisa, eu ligo para a (como chamava a ministra do planejamento do governo Collor, que depois casou com o Chico Anísio? Zélia Cardoso!) Eu ligo para ela e ela faz uma portaria uma medida provisória para resolver rapidamente tudo aquilo. Então eram poderosos. Então assim, a gente conseguiu melhorar um pouco o sistema construtivo, o acabamento, 
escolas, transporte... e logo licitar os espaços para construção de lojas e coisas que estavam previstas. E fazer a drenagem de águas pluviais nesses taludes, o solo frágil... o pessoal verificou que era sild, que é muito, é um solo muito sensível à erosão. Então assim, se tinha um quilômetro de canaletas passou para quinze quilômetros... assim uma proteção contra a erosão que quase não deixava a água se infiltrar. Hoje eu trabalho com infiltração de água, trabalho em Taboão, em Santo André, procurando fazer com que a água de chuva infiltre onde ela cai. Mas naquele momento a gente procurava trabalhar quase sem deixar a água encostar no solo, para não erodir. Quer dizer, gastou-se muito dinheiro com grama para proteger os taludes e a gente fez um programa de plantios também. Mas a gente viu que não teve um monitoramento e elas morreram. Não tinha uma gestão do espaço coletivo adequada."

Como resultado, a política de habitação de interesse social tornou-se uma mercadoria privada, provavelmente superfaturada, e de qualidade questionável. O bairro fruto desta gestão revela problemas decorrentes das opções políticas e técnicas. Os indicadores sócio-econômicos revelam problemas sociais, como altos índices de mortalidade por homicídio, baixa escolarização, alta incidência de gravidez precoce, altos índices de desemprego e salários mais baixos do que no resto da cidade. 


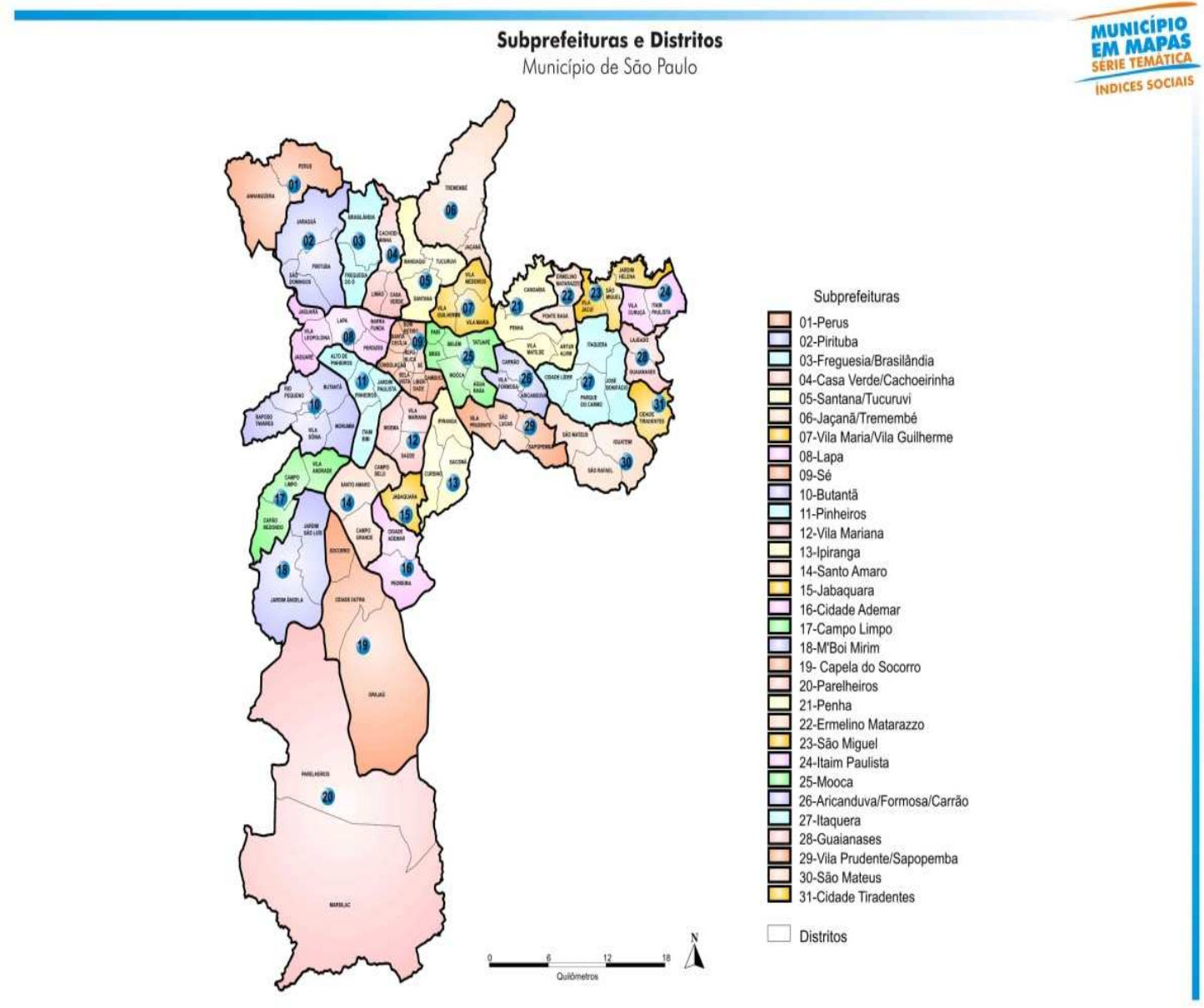

Cidade Tiradentes fica a $35 \mathrm{~km}$ do centro da cidade. Era uma fazenda, chamada Santa Etelvina, uma área verde preservada, de Mata Atlântica nativa. Foi comprada pela COHAB-SP, braço da Secretaria da Habitação, e deu lugar a um dos maiores conjuntos habitacionais da América Latina, a Cidade Tiradentes. Foram construídos no lugar da Fazenda Santa Etelvina, entre os anos 1970 e 1990, os conjuntos habitacionais Santa Etelvina I, II, III e IV, V, VI e VII Barro Branco I e II, totalizando 40.000 unidades habitacionais compostas por prédios de apartamentos e por embriões (pequenos terrenos com uma construção de $32 \mathrm{~m}^{2}$ ). A tipologia mais recorrente são prédios de 4 a 5 pavimentos com apartamentos de em média $37 \mathrm{~m}^{2}$. A densidade demográfica é de 15.307 habitantes por $\mathrm{km}^{2}$ (a densidade demográfica do bairro de Pinheiros, a título de comparação, é de 5.521 habitantes por $\mathrm{km}^{2}$. 

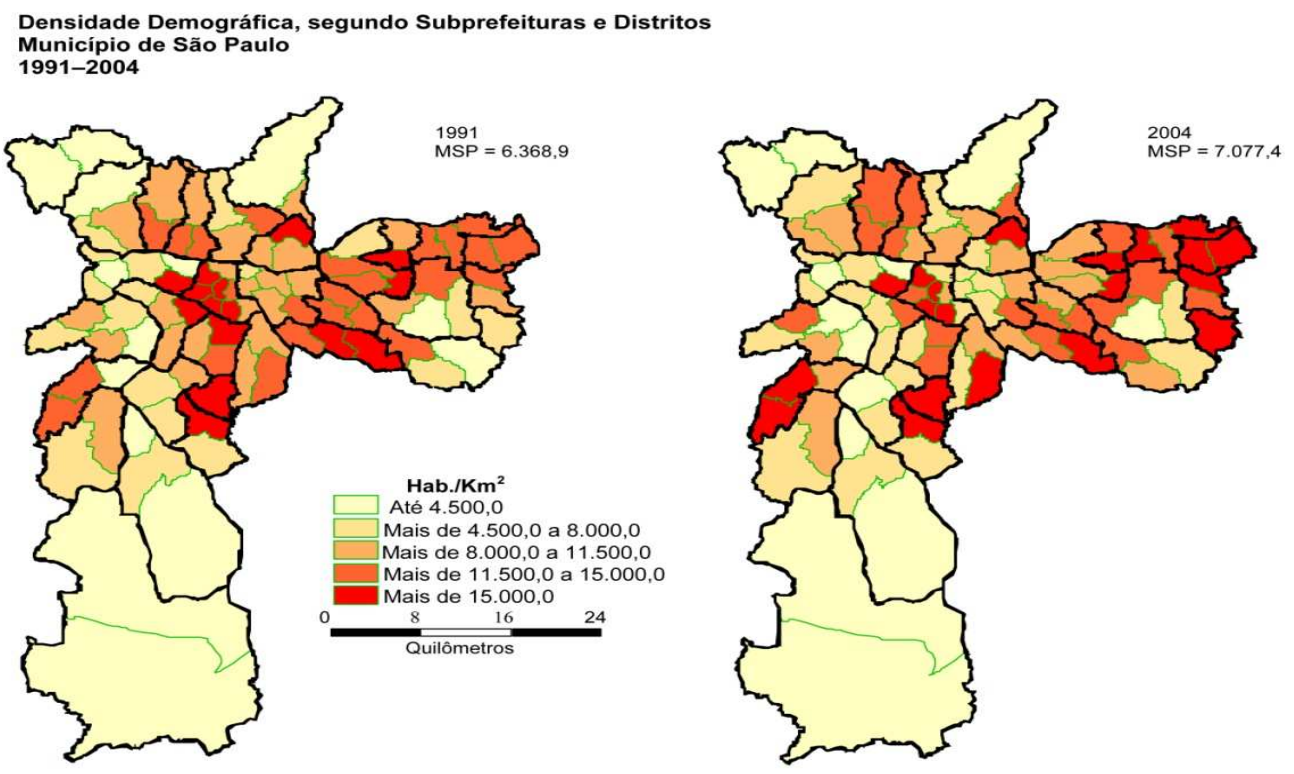

Fonte: Instituto Geográfico e Cartográfico - IGC; IBGE; Fundaçăo Seade

Algumas questões urbanas são evidentes na produção do espaço pelo poder público, como se depreende do estudo da construção da COHAB Cidade Tiradentes:

1. A opção pela produção dos conjuntos habitacionais em Cidade Tiradentes representou custos acima dos esperados, dados os problemas enfrentados com o solo arenoso. As fotos registram as enormes erosões com as quais os empreiteiros se depararam, que ampliaram os custos com a terraplanagem;
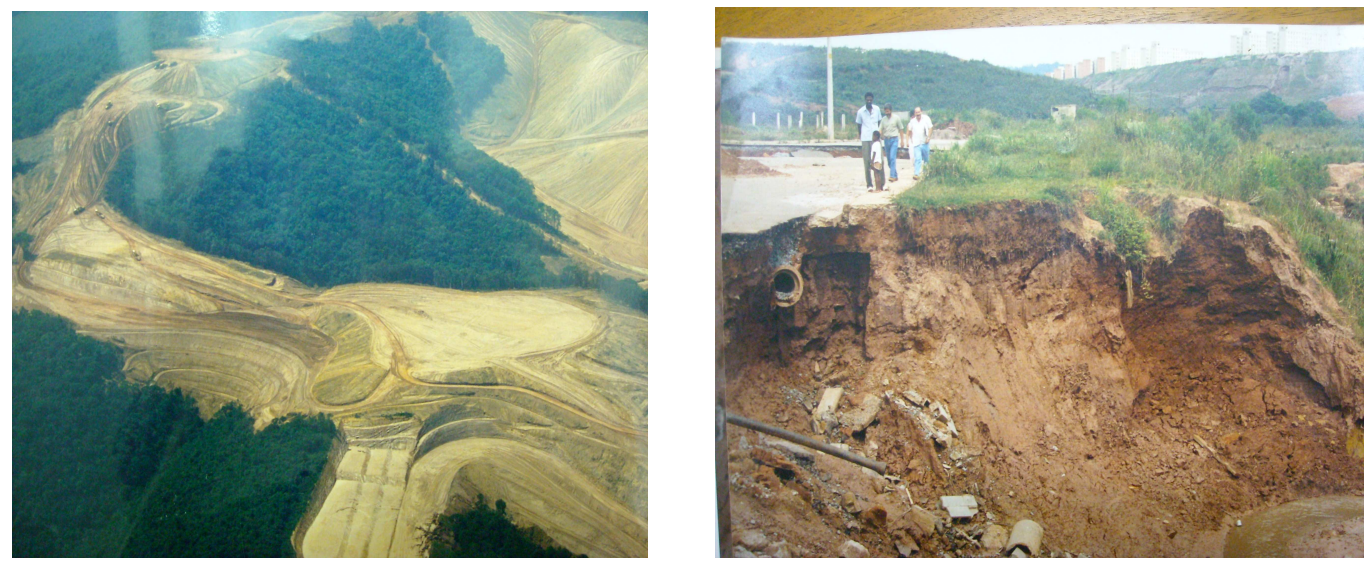

Fotos: Aquivo COHAB-SP

2. A estratégia de produzir os conjuntos habitacionais em terrenos baratos e distantes das áreas centrais redunda em problemas relativos ao acesso ao bairro e dificuldades na instalação de transporte público de qualidade; 
3. Em Cidade Tiradentes, malgrado o investimento público para a construção dos conjuntos, houve falta de planejamento em relação aos equipamentos públicos necessários para atender a população. A luta dos moradores por creches durante toda a década de 1980 evidencia este fato;

4. A produção de conjuntos habitacionais sem planejamento para áreas verdes e áreas públicas vazias induziu ocupações irregulares;

5. A política restritiva de uso dos espaços da $\mathrm{COHAB}$ como espaços estritamente residenciais implicou no desrespeito às normas e na produção de espaços comerciais informais;

6. A política restritiva de comercialização dos apartamentos foi desrespeitada, e a COHAB tem até hoje grande déficit burocrático em relação a identificação dos moradores;

7. A ausência de uma norma clara e a mudança de administrações municipais implicaram num déficit burocrático em relação a regularização da situação de inadimplência dos apartamentos;

8. A segregação urbana e a má gestão dos apartamentos (com reintegrações de posse que deixaram apartamentos vazios ocupados posteriormente) auxiliaram na emergência de intensa violência urbana.

Ao enumeras as debilidades no planejamento e na gestão do conjunto habitacional, busca-se a racionalidade do processo que levou a COHAB-SP, sob a gestão do poder público municipal, investir em tamanho empreendimento. Pressionada por uma lista de demanda por habitação composta por milhares de nomes, a administração municipal à época (final dos anos 1970) optou por uma obra de grandes proporções. Soluções alternativas, como a viabilização de moradias nas áreas centrais, via desapropriação de edifícios vazios, por exemplo, aparentemente não estavam no cenário dos técnicos e políticos de então. A solução para a questão de moradia seguiu a "receita" da política habitacional no período da ditadura: contratação de grandes empreiteiras para a realização de obras gigantescas. Em que pese a fragilidade da indústria da construção civil do ponto de vista dos usos tecnológicos e do ponto de vista 
da baixa qualidade dos postos de trabalho, já tratada, é possível especular que este tipo de política abria espaço para a transferência de recursos para as grandes empreiteiras, grandes financiadoras de campanhas eleitorais de inúmeros políticos paulistanos.

A política de habitação no Brasil obedece à forte presença do Estado, como analisou Arretche (1990). A natureza desta presença é como organizador da inserção de empresas privadas no mercado. Paralelo à ação do Estado como fomentador da chamada habitação de interesse social, ocorreu durante as décadas 1970 a 1990 um enorme incremento do mercado imobiliário, com especulação de territórios nas áreas centrais da cidade. ${ }^{34} \mathrm{O}$ Estado esteve presente em todos os momentos induzindo a especulação imobiliária, por meio do investimento vultuoso em obras viárias nas regiões mais valorizadas. Não se trata, como vemos, de abandono das áreas periféricas, mas da qualidade do investimento público numa e noutra área da cidade. $\mathrm{O}$ investimento público nas áreas centrais induz à valorização imobiliária (obras para melhorar o tráfego, por exemplos, que têm também grande presença do ponto de vista da paisagem), o que não acontece nas áreas periféricas, em que o investimento é quase que exclusivamente voltado aos serviços públicos básicos (o investimento em transporte público é também mais restrito). A remoção da favela Água Espraiada evidencia a dinâmica do investimento do Estado. Em 1995, a favela foi removida para dar lugar à remodelação da avenida dentro da Operação Urbana Faria Lima. Aos moradores expulsos a prefeitura ofereceu duas alternativas: comprar uma moradia construída pela prefeitura na Cohab Barro Branco ou receber uma quantia em dinheiro (que variou conforme a intensidade da resistência dos moradores em sair dali) Fix (2001). Os moradores foram para a Cidade Tiradentes e para áreas às margens da represa Guarapiranga, na região de mananciais.

O Estado pode, portanto, dispor dos trabalhadores no espaço, conforme o interesse de grupos de pressão (que têm poder) em determinada área. $\mathrm{Na}$ fase concorrencial e financeira do capitalismo global o poder de barganha do trabalhador (o proletário) é pequeno frente às corporações e interesses institucionalizados. Mesmo nos países de economia central, em que o welfare state consolidou conquistas dos

${ }^{34} \mathrm{O}$ custo do metro quadrado às margens do Rio Pinheiros subiu de 800 dólares (na década de 1970) para 3,5 mil a 4 mil dólares no final dos anos 1990, segundo Fix (2001). 
trabalhadores a corrosão de direitos é uma realidade. No capitalismo selvagem dos países periféricos, históricos fornecedores de mercado de trabalho barato para as companhias internacionais, os direitos sociais foram uma conquista longa e difícil dos movimentos organizados, mas desde a emergência de governos neoliberais, os direitos sociais passaram a ser deslocados do foco da atenção do Estado, e os serviços públicos foram sucateados. No campo da saúde, da educação e da moradia, o entendimento da sociedade é que o mercado privado é mais eficiente para suprir serviços de qualidade, pois baseia-se na livre concorrência e, portanto, na busca pela excelência. Os serviços públicos, ao contrário, são considerados burocráticos e ineficientes. Os serviços públicos passaram a ser orientados para uma parcela da população cuja renda não permite o acesso aos serviços privados. O papel do Estado é regulador dos serviços privados e executor dos serviços públicos, num processo que tem sido chamado de gestão da pobreza. (Oliveira \& Rizek, 2007). A moradia, embora consolidada enquanto direito pela letra da Constituição de 1988, na prática é uma mercadoria, e, como tal, inscreve-se na lógica liberal da oferta e procura. $\mathrm{O}$ mercado imobiliário usualmente garante seus lucros com a especulação imobiliária nas áreas centrais e a demanda por habitação de interesse social é provida a partir de grandes acordos entre o Estado e as empreiteiras. O próprio termo "habitação de interesse social" nos remete à idéia de que o interesse social não é o interesse de toda a sociedade, mas de um segmento. O social, numa operação fortemente ideológica, passou a ser, a partir da democratização no final dos anos 1980, um slogan político partidário para definir o apoio aos pobres. O Estado atua no sentido da ampliação da especulação nas áreas centrais e como mantenedor de uma política voltada a quem "precisa”, população que é também uma massa de votos consideráveis, para quem o discurso de Estado benfeitor é dirigido em épocas de eleições. Não são raras as listas de moradores apresentadas ao poder executivo via interesses eleitorais de candidatos a vereadores e vereadores, bem como as anistias às dívidas de financiamento dos mutuários em épocas de pré-eleição. 


\section{Produção Estatal de Habitação em Cidade Tiradentes}

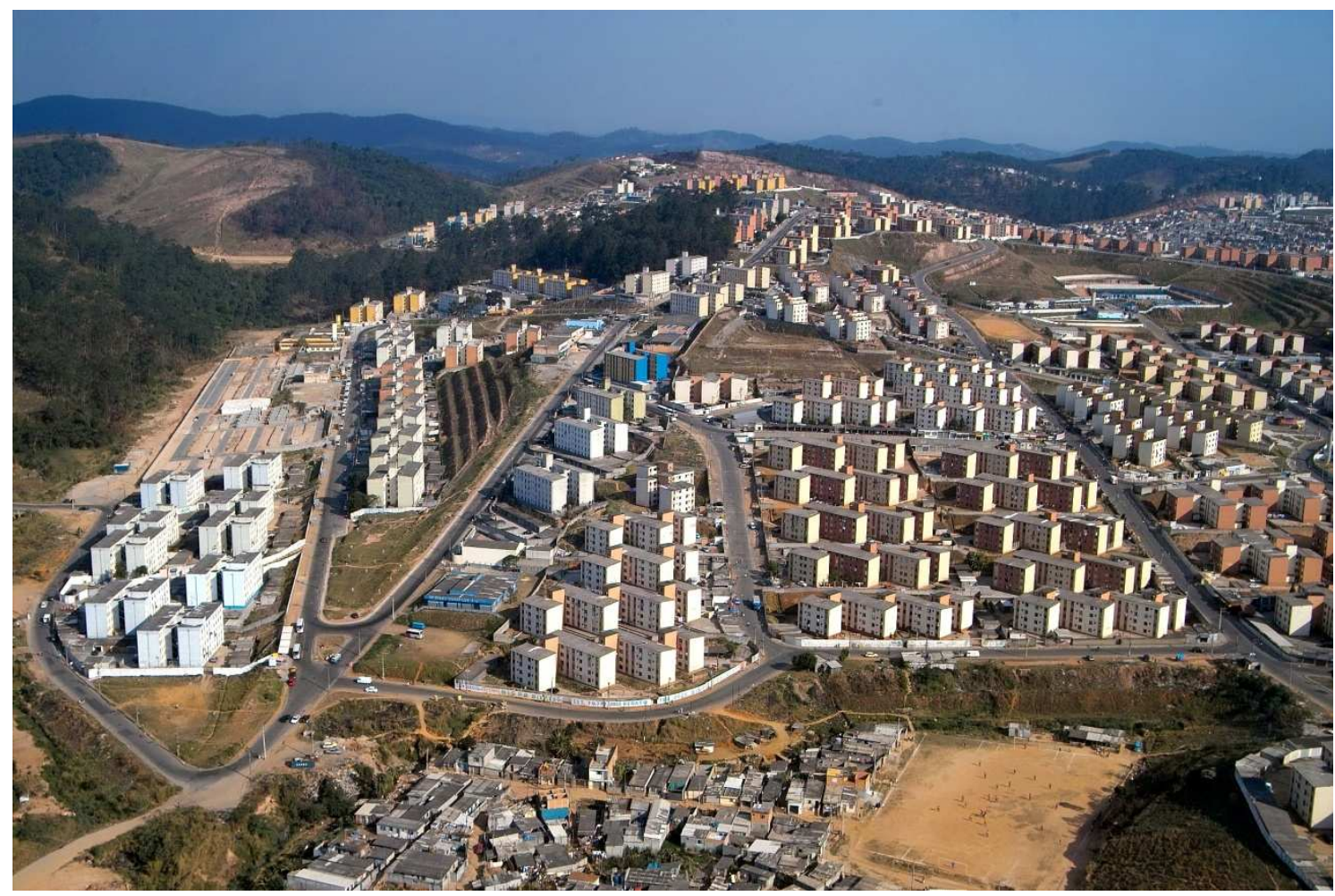

Foto: Jorge Hirata. Pesquisa Mobilidades urbanas e trajetórias sociais: trabalho, moradia e mobilidade cotidiana.Coordenação: Vera Telles e Robert Cabanes.

Encravado na mata recortada o distrito é composto quase que exclusivamente por conjuntos habitacionais. Os conjuntos são compostos por edifícios de apartamentos ou por "embriões": pequenos terrenos entregues pela COHAB com edificações de quarto-e-sala. Os moradores dos embriões, com o tempo, investiram na ampliação das casas nos terrenos. A paisagem é formada por edifícios e casas realizadas por autoempreendimento, com a visão em perspectiva dos terrenos vazios e da mata atlântica. É uma paisagem diferente da paisagem zona leste adentro (da autoconstrução, fabril e de comércio), pois é uma paisagem em que a visão dos prédios é recorrente, emoldurada pela mata. Do ponto de vista de projeto, pode-se dizer que o grande conjunto habitacional é uma expressão rebaixada da arquitetura moderna: prédios funcionais, 
apartamentos pequenos, equipamentos públicos. As tipologias dos primeiros edifícios da COHAB-SP são similares. O edifício mais comum é em forma de H, com três blocos de quatro andares. Mais recentes são edifícios do PAR - Programa de Arrendamento Residencial, edifícios mais altos e compactos.
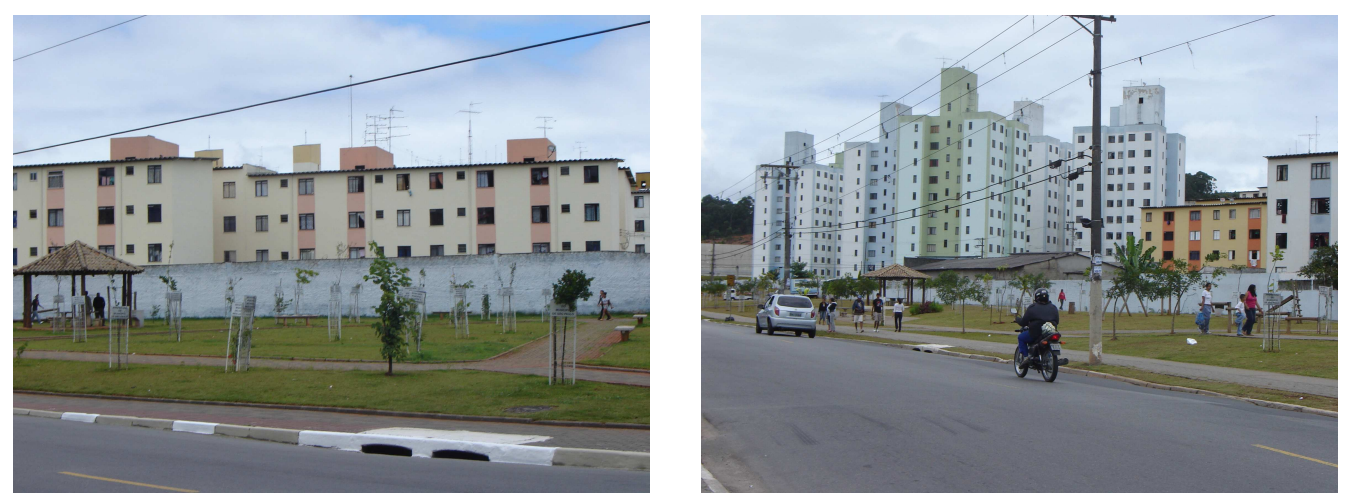

Tipologia de Edifício: COHAB-SP (à esquerda) e PAR (à direita)

A topografia é montanhosa, há muitas ladeiras. As vias recortam os lotes. A via principal, pela qual se tem acesso ao bairro, é a Avenida dos Metalúrgicos, em que está concentrado o comércio da região. A avenida é margeada por uma praça contínua. Adentrado no bairro, no entanto, as áreas verdes públicas são poucas. No interior do bairro, são freqüentes áreas da $\mathrm{COHAB}$ não ocupadas. Os grandes edifícios públicos (escolas de ensino médio e fundamental, mercado municipal) têm fachadas lisas em e simples, em tons pastéis. As unidades básicas de saúde e escolas de ensino fundamental têm fachadas desenhadas.
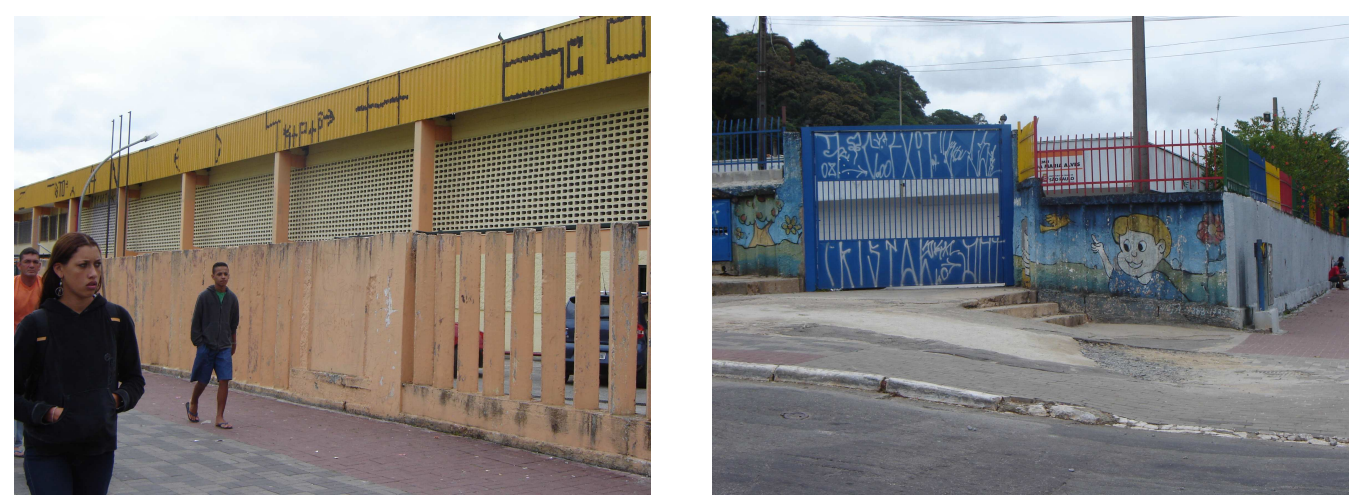

Escola Estadual (à esquerda) e Escola de Educação Infantil (à direita) 
Na circunferência externa do bairro o comércio é consolidado: uma grande rede de supermercados marca presença ali, bem como uma filial de uma grande rede de comércio de móveis voltada ao mercado popular, instalada no bairro no início dos anos 2000 e sinal de "progresso".

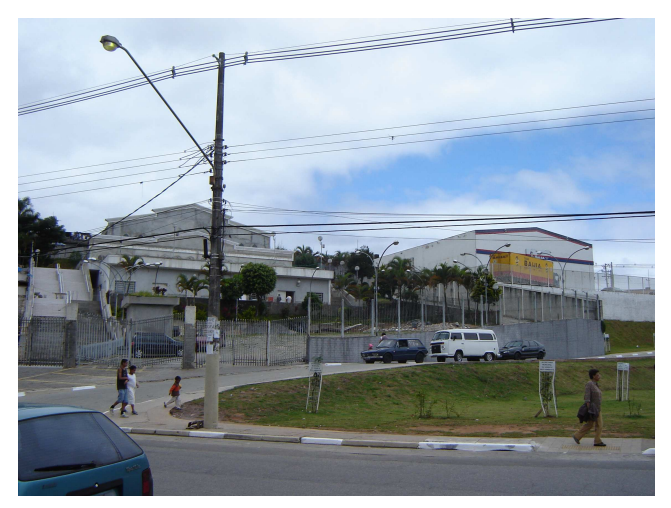

Igreja e Loja de Comércio de Móveis, próximas ao Terminal de Ônibus.

Neste círculo externo as igrejas são grandes galpões que abrigam fiéis de credos também presentes na cidade como um todo: Igreja Universal do Reino de Deus, Congregação Cristã no Brasil. Na Avenida dos Metalúrgicos estão localizadas igrejas localizadas em garagens menores (como a Igreja Batista) e um comércio de menor porte, mas diversificado: farmácias, açougues, mercados, lojas de roupas, lojas de calçados, óticas, pet shops, salões de cabeleireiro. O comércio nas ruas menores é menos diversificado: os salões de cabeleireiro também estão presentes, mas são mais comuns os bares, e as pequenas bomboniéres (onde vendem-se doces industrializados) e papelarias. Este comércio nas áreas menos centrais é também aparentemente menos próspero.

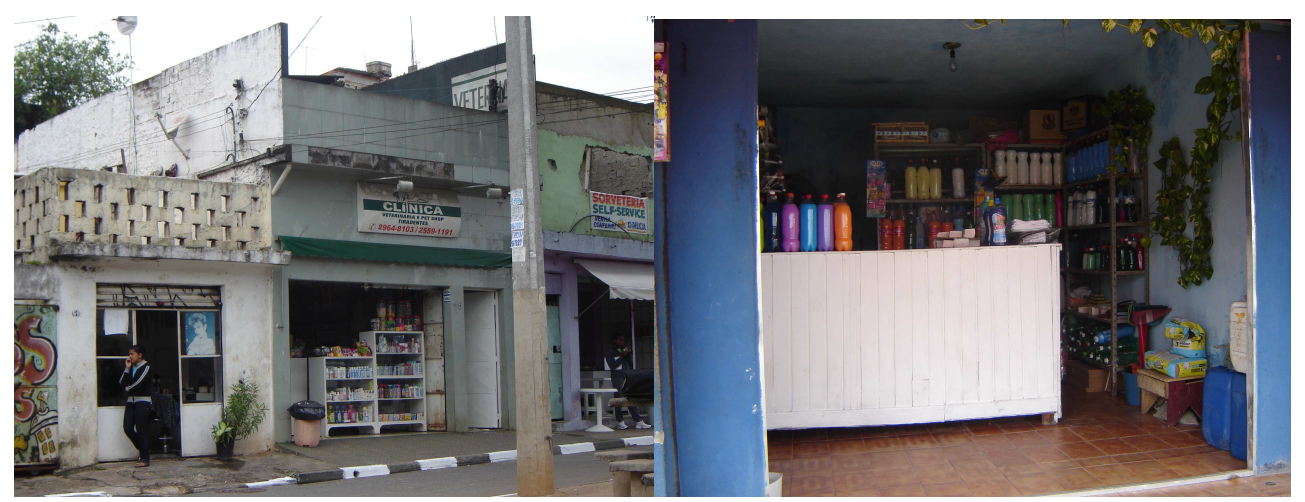


Comércio em garagens de embriões e edifícios. Na Av. dos Metalúrgicos (à esquerda) e numa rua dentro do bairro (à direita).

Tanto as tipologias dos edifícios quanto seu estado conservação diferem. As fachadas, o revestimento dos edifícios são mantidos pelos moradores. Ente os embriões, os projetos individuais revelam a diversidade de recursos empregados no autoempreendimento da casa própria. Da mesma forma, melhorias implementadas em alguns edifícios revelam situações condominiais de maior ou menor prosperidade.
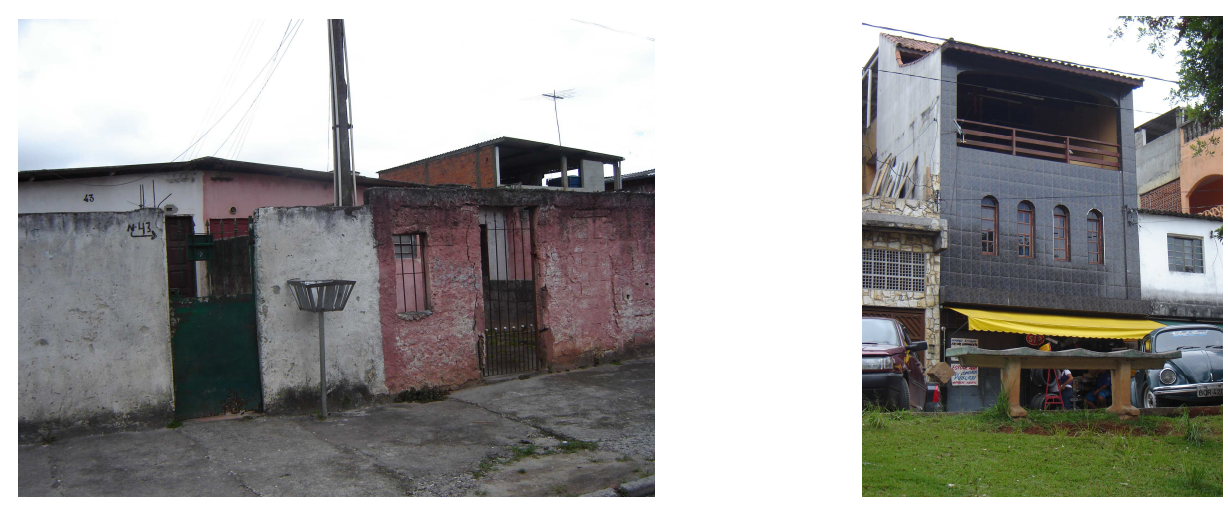

Embriões

A maior parte dos edifícios não têm manutenção e revela os traços do material construtivo precário: umidade, pintura desgastada. O acabamento é responsabilidade dos moradores, bem como a manutenção das áreas comuns, da fachada e paredes externas dos edifícios.
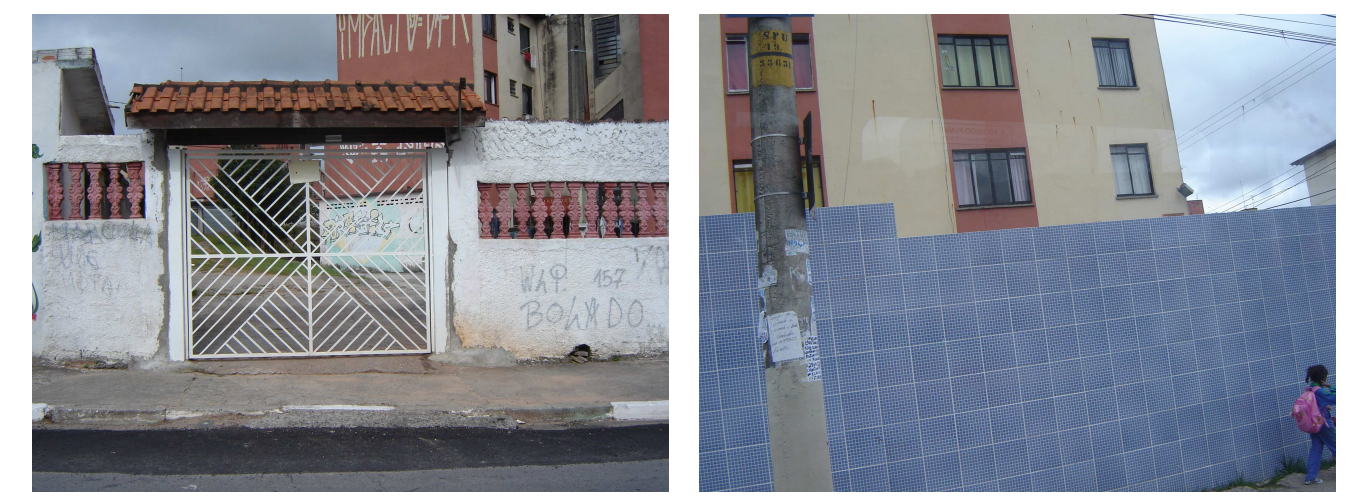

Detalhe do portão elétrico de edifícios (esq) e muro revestido (dir). 
As ruas foram desenhando quadras grandes, mas desiguais. Grandes ladeiras e ruelas tornam a locomoção difícil. Além disso, as vans que realizam o transporte local fazem poucos percursos.

Nos primeiros anos, Cidade Tiradentes poderia ser considerada como uma cidade dormitório: o bairro todo era um amontoado de embriões e edifícios de apartamentos pequenos. Os moradores chegavam de todas as partes da cidade, vindos de condições de habitação ou situações familiares mais precárias, e entravam nos apartamentos e nos embriões em busca, invariavelmente, do sonho da casa própria. O sonho confrontava-se com a dura realidade dos ônibus e trens lotados nas duas únicas linhas de ônibus existentes, percorrendo não raro três horas de viagem até as regiões de seus empregos. Considerada área rural pela administração municipal, comércio inexistente, serviços públicos de educação e saúde insuficientes, a escolha pela Cidade Tiradentes revelava a falta mesmo de alternativas destas famílias diante da atuação reduzida da política habitacional.

Os relatos tratam da opção pelo apartamento para "sair do aluguel”, preservando um pouco mais os baixos salários, ou, ainda, a busca de um espaço próprio, deixando a casa dos sogros, por exemplo. Ao chegar ali, tudo era a experiência da falta. Os relatos falam de apartamentos vazios, dificuldades em questões básicas, como compra de alimentos e falta de atendimento médico. Os prédios ainda estavam vazios e as ruas eram escuras. Para irem até o ponto de ônibus muitas pessoas precisavam andar na madrugada por passagens abertas em região de vegetação densa. Faltava água e luz freqüentemente. Os ônibus eram raros e quando chegavam estavam lotados. Os moradores relataram que eram comuns os assaltos a caminho do trabalho.

Aos poucos, formaram-se associações de moradores, que ligavam-se ao Partido dos Trabalhadores, que crescia entre os bairros periféricos de São Paulo, sobretudo na zona leste da cidade. Estes movimentos reivindicavam creches, escolas, atendimento em saúde básica, transporte público. Os líderes destes movimentos, encabeçados por padres católicos da Teologia da Libertação, mobilizavam os moradores e realizavam atos de mobilização no centro da cidade. Negociações eram abertas a partir destes movimentos 
de pressão e aos poucos as conquistas foram chegando, como a construção de escolas e postos de saúde, além das linhas de ônibus. Entre as administrações mais resistentes às demandas as lideranças do movimento citam as gestões de Paulo Maluf (1993-1996) e Celso Pitta (1997-2000). Foi na administração de Paulo Maluf que ações de expulsão de moradores das áreas ocupadas foram tomadas pela Prefeitura. ${ }^{35}$ A organização local ampliou-se, bem como a representação político-partidária. Em 2008, $70 \%$ dos moradores de Cidade Tiradentes votaram em Marta Suplicy no segundo turno. Como resposta a este apoio maciço, a administração petista realizou o mais intenso investimento público que o distrito já vira desde a sua criação. Foram construídos dois Centros de Ensino Unificados, um Hospital Municipal e uma Escola Técnica. ${ }^{36}$
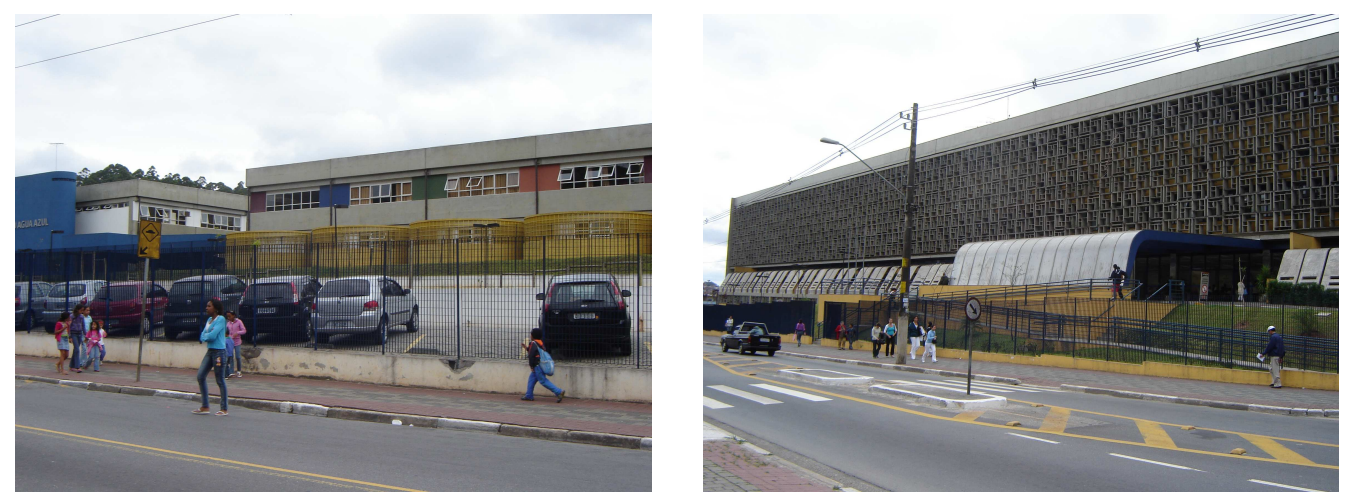

CEU Água Azul e Hospital Municipal da Cidade Tiradentes - embora inaugurados na gestão José Serra-Gilberto Kassab (2005-2008), foram concebidos na gestão Marta Suplicy (2001-2004).

A história de Cidade Tiradentes descortina um encontro entre o saber técnico dos agentes ligados às diferentes administrações e o cotidiano de famílias de moradores. Entre as administrações Jânio Quadros (1986-1988) e a administração Serra-Kassab (2005-2008), passando pelas administrações Luiza Erundina (1989-1992), Paulo Maluf

${ }^{35}$ O trabalho de Slomianski (2002) mostra que as ocupações correspondiam, no final dos anos 1990, a $26 \%$ das áreas destinadas à $\mathrm{COHAB}, 12 \%$ das áreas verdes, e 22\% das áreas públicas vazias.

${ }^{36}$ É importante, contudo, salientar as críticas presentes no relato dos moradores. O hospital municipal, por exemplo, é uma estrutura gigantesca, mas na época da pesquisa (2007) não oferecia atendimento, pois faltavam médicos. Segundo os moradores entrevistados, o atendimento prestado era de má qualidade. O projeto inicial da escola técnica era de uma faculdade de tecnologia na área de saúde, com o objetivo de formar quadros na região. 
(1993-1996), Celso Pitta (1997-2000) e Marta Suplicy (2001-2004), houve diversas gestões da Secretaria de Habitação e da COHAB-SP, enfrentando de modos diversos as questões e demandas que o maior conjunto habitacional da América Latina colocava.

Paralelamente à ação de agentes ligados ao poder público, como arquitetos, assistentes sociais, empresas de construção civil, na produção física dos conjuntos habitacionais, descortinavam-se trajetórias de vida em busca de trabalho na São Paulo das fábricas, em que "o trabalho procurava o trabalhador". Mesmo na época áurea dos trabalhadores paulistanos, no auge da industrialização dos anos 1970, não era na Cidade Tiradentes que estavam os operários sindicalizados e combativos que fizeram a história da cidade e do país. As grandes fábricas estavam localizadas no ABC paulista e na zona sul da cidade. A pesquisa descrita por Telles (2006) em regiões do extremo sul e do extremo leste da cidade revela que a concentração geográfica dos empregos foi também a concentração de estratégias de moradia diferenciadas. Nos bairros da zona sul existem as experiências do Pró-Morar ${ }^{37}$, e muitos bairros foram consolidados. A expansão a sul segue os efeitos da reestruturação produtiva e do crescimento demográfico, combinando redução de empregos fabris e ampliação de empregos de serviços para uma população mais jovem. Na zona leste, os empregos fabris concentravam-se em bairros como São Miguel Paulista, que era também um bairro de operários do ABC Paulista. Mais à leste destes bairros os trabalhadores eram os aqueles ligados à experiência do subemprego nas cadeias produtivas e das empregadas domésticas. Os efeitos da reestruturação produtiva, no entanto, se fizeram sentir mesmo nas áreas mais distantes das cadeias produtivas. O desemprego e a informalidade são a tônica dos anos 1990, acirrados com o declínio dos movimentos sociais, a ascensão de partidos de direita no executivo municipal e a proliferação de igrejas evangélicas. A gestão pública municipal passa a atuar com convênios no campo da assistência social, passa por modelos de gestão da saúde e da educação com características despolitizantes. O cidadão passa a ser entendido como "clientela", e os indicadores de eficiência criam um emaranhado de dados que não se referem diretamente à qualidade do atendimento ou ao grau de aprendizado. As experiências de orçamento participativo e conselhos municipais, ao mesmo tempo em que fomentaram a participação popular, denotam os limites desta

\footnotetext{
${ }^{37}$ Programa habitacional criado em 1979, ligado ao SFH, baseado na construção de moradias de alvenaria em regiões de favelas.
} 
participação: a gestão é compartilhada, mas as decisões são limitadas pelas alíneas orçamentárias decididas em outros fóruns. Não se trata de lutar pelo "fundo público" de forma igualitária, mas gerir o que cabe aos pobres ${ }^{38}$.

A ocupação real e simbólica de Cidade Tiradentes obedeceu à indução do Estado. Famílias de trabalhadores oriundas de diferentes estados da federação, após algum tempo de permanência em São Paulo, inscreveram-se para o sorteio de apartamentos da COHAB-SP. ${ }^{39}$

A maior parte das decisões acerca do uso do espaço foi tomadas pelo poder público por intermédio da COHAB-SP. Foi a instituição, materializada na ação de seus funcionários, orientados pelo discurso/ prática de instalação de moradias populares (bastante bem examinadas por Nakano (2002) como desenvolvimento da arquitetura moderna capitalista) quem comprou os terrenos, planejou o traçado urbano e o executou por meio de empresas de construção civil. Também as regras de financiamento dos imóveis foram decisão da COHAB-SP. Os moradores não participaram de nenhuma destas etapas, tampouco houve qualquer tipo de consulta popular em relação ao projeto. Os moradores haviam sido inscritos e os apartamentos foram destinados a eles mediante sorteio. As regras de uso do espaço postas pela COHAB-SP definiram o uso como estritamente residencial (aos demandantes de espaços comerciais coube a proposta de locação de um dos espaços da COHAB-SP). Desta forma, aos moradores do conjunto coube a gestão e manutenção do espaço interno ao prédio bem como do espaço que circunda cada conjunto.

Se a maior parte do poder sobre o espaço foi mediada por uma instituição pública, a relação com ela, e também a relação com o espaço coletivo em muito já prédeterminado, seguiu inúmeros percursos diferenciados. Observando os inúmeros conjuntos percebemos que a convivência entre as famílias em cada um deles definiu espacialidades diferenciadas, resultantes de relações sociais diferenciadas. Há prédios

\footnotetext{
${ }^{38}$ Sobre a disputa pelo "fundo público" ver Oliveira (1998).

39 Esta é uma observação baseada em experiência de campo, como assistente na pesquisa "Cidade e Cidadania - Mobilidades" entre 2001-2002 e 2005 e confirmada pela pesquisa de mestrado. Infelizmente a COHAB não mantém em seus arquivos registros sobre os moradores, de forma que a confirmação de dados demográficos e de origem populacional fica restrita ao censo, cujas informações são agregadas.
} 
nos quais, ao largo da proibição da $\mathrm{COHAB}$, moradores implementaram pequenos comércios. Há prédios pintados, como há prédios cuja textura revela o abandono de duas décadas. Em alguns deles foram plantados jardins. Em alguns prédios a grama atinge tamanho e aspecto de um matagal.
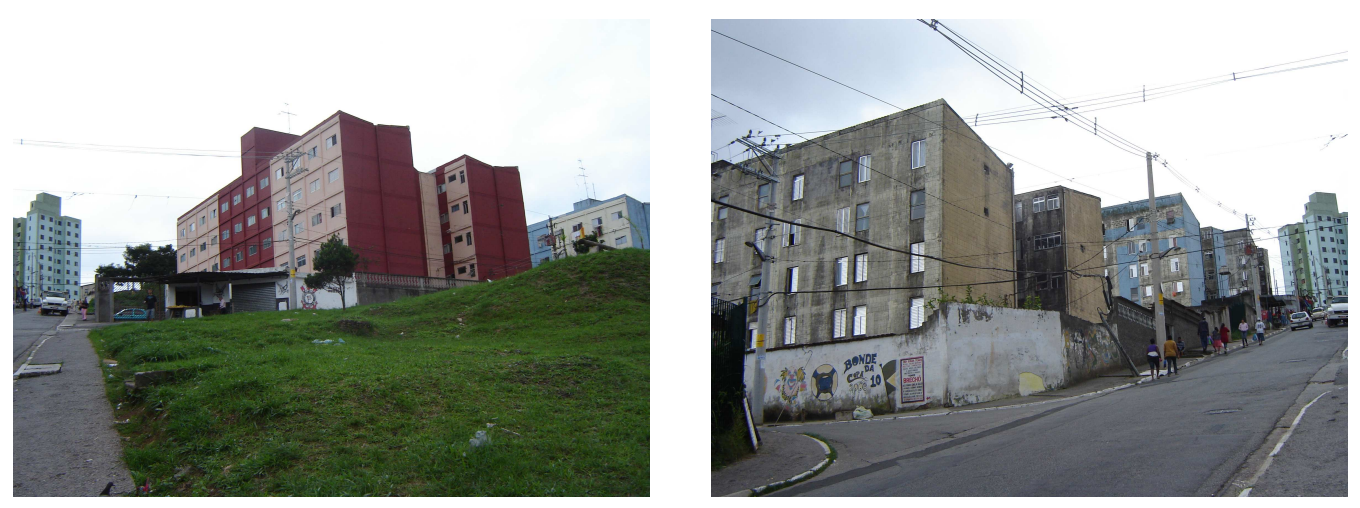

Diferenças de manutenção de fachadas dos edifícios.

A ocupação do espaço partiu de ações de poder de Estado, favorecendo grandes construtoras e abrindo espaço aos interesses especulativos do mercado imobiliário nas regiões centrais. Diante desta realidade, coube às famílias de baixa renda a situação de moradia em apartamentos de pequeno tamanho num bairro sem infra-estrutura alguma, distante $35 \mathrm{~km}$ do centro da cidade.

Por outro lado, o poder do Estado não se manifesta apenas no acesso à moradia, mas na cotidianeidade dos moradores dos conjuntos habitacionais. O poder exercido pelo Estado em relação à vida dos agentes sociais é internalizado e as pessoas passam a exercê-lo na relação com o outro - na gestão da água do prédio, no afastamento dos vizinhos, por exemplo. Este é o tema central de nossa pesquisa, e será analisado de forma aprofundada no capítulo terceiro.

"Como esses espaços de mediação permitem ou recusam as transformações tanto espaciais quanto sociais que permitem ir do público ao privado (e retornar?). Como as populações consideradas vêem essas transformações e transições, elas mesmas e suas relações com as outras? Quais são as contradições ou as tensões sociais que esses espaços cristalizam? Quais características, propriedades ou extensões/significações do público ou do privado devem estar em conta para compreender as evoluções relativas?" (Haumont \& Morel, 2005, p. 26, tradução da autora). 


\section{Alguns Indicadores Sociais}

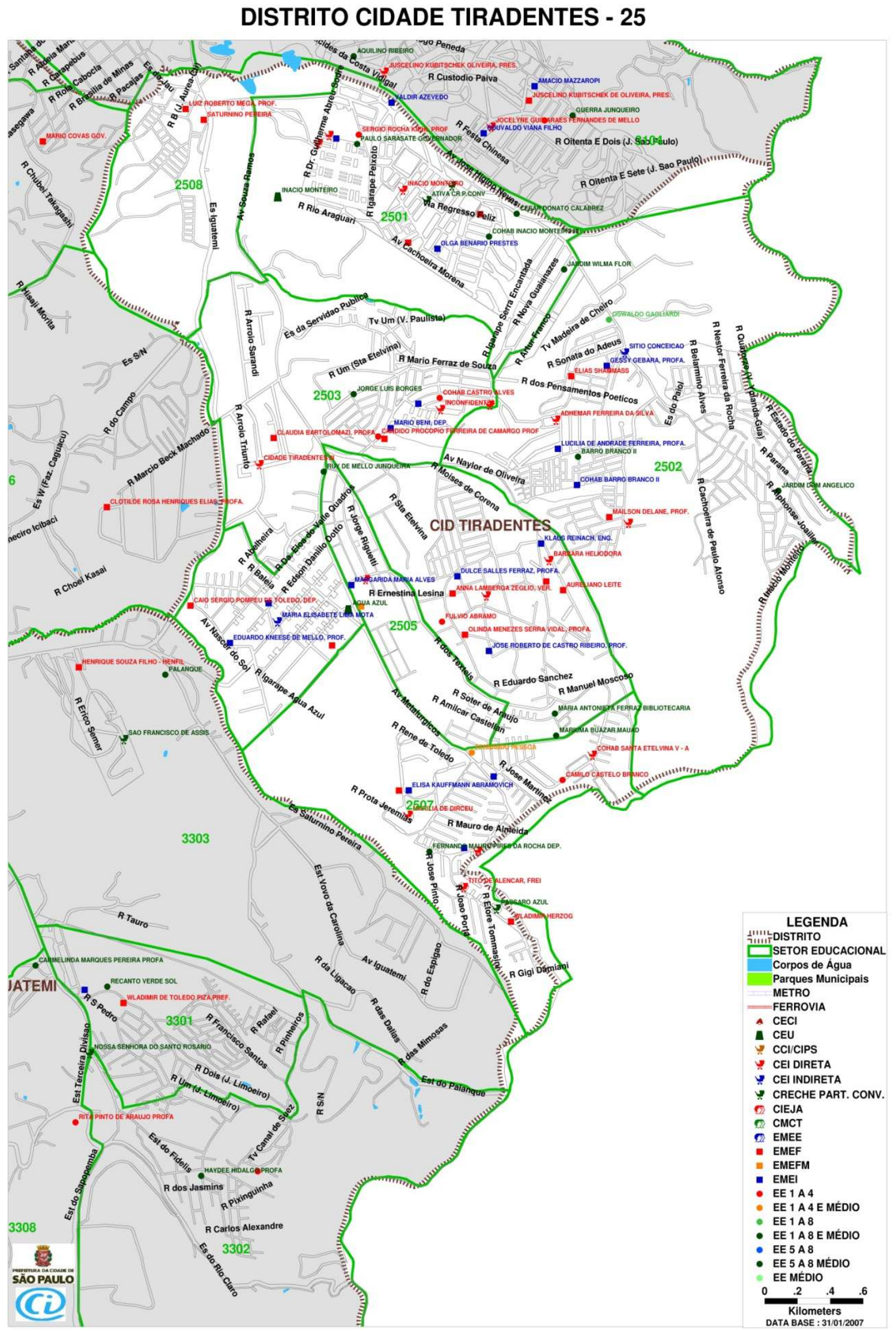


Nos últimos anos a produção de indicadores sociais sobre a Região Metropolitana de São Paulo tem-se ampliado substancialmente. Dados provenientes dos Censos decenais e de pesquisas mensais, como a pesquisa de Emprego e Desemprego da Fundação Seade são complementados com pesquisas específicas, como a PNAD Pesquisa Nacional de Amostras Domiciliares. Estas pesquisas, bem como dados de registros de serviços públicos como saúde e educação, têm sido fonte para a elaboração de indicadores sociais, cujo objetivo principal é o subsídio ao planejamento de políticas.

Exercícios teóricos como o Mapa da Exclusão/ Inclusão Social contribuem para a visualização da inscrição territorial das populações. Por meio do mapa da Exclusão/ Inclusão Social a segregação sócio-espacial torna-se visível: os indicadores que remetem às dinâmicas de pobreza estão localizados nas áreas periféricas da cidade. Vêse, por exemplo, que a renda é mais baixa nas regiões periféricas da cidade.

Neste tópico descrevem-se um conjunto de indicadores sociais ligados ao Mapa da Vulnerabilidade Juvenil, evidenciando o processo de segregação sócio-espacial. Ao mesmo tempo, dados demográficos contextualizam a Cidade Tiradentes. Apresenta-se um conjunto de tabelas em que se podem comparar dados dos diferentes distritos da cidade, em relação às ocupações e rendimentos. Veremos que tanto do ponto de vista do emprego formal quanto do emprego informal, Cidade Tiradentes é o distrito com menores índices de ocupação. Do ponto de vista da renda, em todas as atividades produtivas (comércio, serviços, indústria e construção civil), os números de Cidade Tiradentes são inferiores aos demais distritos.

O Censo Demográfico do IBGE no ano 2000 contabilizou 190.644 moradores em Cidade Tiradentes. Segundo dados distritais da Fundação Seade, a população em 2008 era igual a 242.077 pessoas (1,23\% da população total da RMSP). A título comparativo, a população do distrito Alto de Pinheiros equivalia no mesmo ano a 40.637 pessoas (ou $0,20 \%$ do total de população).

A taxa de crescimento da população na Cidade Tiradentes foi de 17,16 entre 1996 e 2000, segundo a PMSP. Entre 2000 e 2008 foi 3,11\%, segundo a Fundação Seade. Este índice alto índice de crescimento foi verificado apenas em outros distritos periféricos como Anhangüera $(5,58)$ e revela expulsão de moradores das áreas centrais 
da cidade (no Bom Retiro o crescimento foi negativo: -2,57). Na RMSP o crescimento foi de 1,24 (Dados da Fundação Seade).

Os moradores estavam em 49.840 domicílios. A densidade demográfica média na RMSP é de 2.480 moradores por $\mathrm{km}^{2}$. No distrito de Aricanduva a densidade demográfica média é de 13.757 moradores por $\mathrm{km}^{2}$; no distrito do Alto de Pinheiros é 5.403 moradores por $\mathrm{km}^{2}$ e no distrito de Cidade Tiradentes é de 16.009 moradores por $\mathrm{km}^{2}$. (Dados da Fundação Seade).

Grande parte da população (42\%) tinha de 1 a 5 anos de estudo. 24,6\% tinham de 6 a 10 anos de estudo; 16,6\% de 11 a 15 anos de estudo; 6,4\% estavam entre a população com menos de 1 ano de estudo ou sem instrução e apenas 0,4\% da população tinha mais de 15 anos de estudo. Entre os responsáveis por domicílio, 39,58\% tinham ensino fundamental completo (a taxa no município de São Paulo é de 49,69\%). Entre os responsáveis por domicílio com ensino médio completo, a taxa em Cidade Tiradentes era de $16,87 \%$ contra $33,68 \%$ no município de São Paulo.

A grande causa de mortalidade em Cidade Tiradentes eram em 2003 os homicídios. Foram registrados 122 homicídios e 76 doenças do coração no ano, segundo a Secretaria Municipal de Saúde. No distrito da Bela Vista, no mesmo período, foram registrados 8 óbitos por homicídio.

Em 2003 não havia leitos do SUS em hospitais na Cidade Tiradentes.Todos os indicadores de saúde mostram a situação de precariedade do atendimento e inúmeros problemas de saúde no distrito. A taxa de mortalidade materna, por exemplo, indicador da Fundação Seade e da Secretaria Municipal de Saúde, contabilizava 81,63 mortes por 100.000 nascidos vivos; contra 55,05 no município de São Paulo.

As tabelas 1 e 2 (vide anexo 1) referem-se ao número de postos de trabalho na cidade, por distrito. Como se pode ver na tabela 1, o número de empregos formais criados em Cidade Tiradentes no ano de 2004 era inferior ao número de empregos criados nos distritos mais pobres da cidade, como Perus. Em Cidade Tiradentes foram criados 430 empregos, ao passo que em Perus foram criados 758 empregos. Os empregos em Cidade Tiradentes correspondem a 0,25\% dos empregos criados na cidade 
no mesmo ano. O bairro que mais gerou empregos no ano foi a Sé, com 47.415 empregos, ou o equivalente a $16 \%$ dos empregos criados.

O número de empregos formais em 2002 era também menor do que em todos os outros distritos, como se pode observar na tabela 2. Em Cidade Tiradentes havia 6.195 empregos, ou o equivalente a $0,19 \%$ dos empregos em toda a cidade. Um distrito igualmente periférico, como Parelheiros, contava com 16.508 postos de trabalho formais $(0,50 \%)$.

A maior parte dos empregos formais em 2002, como se vê na tabela 3, concentra-se na área de serviços. (65\%). 12\% dos empregos são na indústria, 1,5\% na construção civil e 20,5\% no comércio. Se, por um lado, esta distribuição é semelhante à da cidade como um todo (14,5\% na indústria, $4,0 \%$ na construção civil, $16,1 \%$ no comércio e 65,4\% nos serviços) em bairros como Aricanduva e Mooca, a concentração dos empregos industriais ultrapassa os $30 \%$. Por outro lado, bairros industrializados nas décadas de 1980 e 1990 perderam postos industriais, como Santo Amaro, que em 2002 contabilizava $12 \%$ dos seus empregos na indústria.

As tabelas 4 e 5 referem-se ao rendimento dos moradores por distrito. Em relação à renda, 57\% dos moradores em Cidade Tiradentes recebiam, em 2000, até 5 salários mínimos; enquanto que na Consolação 69\% dos moradores recebiam mais de 10 salários mínimos.(Tabela 4)

Os salários nominais em 2002 também eram mais baixos na Cidade Tiradentes. $\mathrm{Na}$ indústria os salários são semelhantes, mas nas atividades como construção civil e serviços eles são visivelmente mais baixos do que no resto da cidade, como se observa na tabela 5. Os salários em Cidade Tiradentes são em média 39\% mais baixos do que na média da cidade. Em relação ao distrito com a média salarial mais alta (Parelheiros), a diferença chega a $60 \% .^{40}$

Cidade Tiradentes é um dos distritos com pior índice de vulnerabilidade juvenil, indicador criado pela Fundação Seade composto por indicadores pela taxa anual de

\footnotetext{
${ }^{40}$ Este dado surpreende. O distrito de Parelheiros, no qual se situam bairros extremamente pobres, também abriga condomínios de luxo que talvez sejam a origem do dado.
} 
crescimento populacional, percentual de jovens de 15 a 19 anos na população por distrito, taxa de mortalidade por homicídio da população masculina de 15 a 19 anos, percentual de mães adolescentes, de 14 a 17 anos, no total de nascidos vivos, valor do rendimento médio mensal, das pessoas com rendimento, responsáveis pelos domicílios particulares permanentes e percentual de jovens de 15 a 17 anos que não freqüentam a escola. 


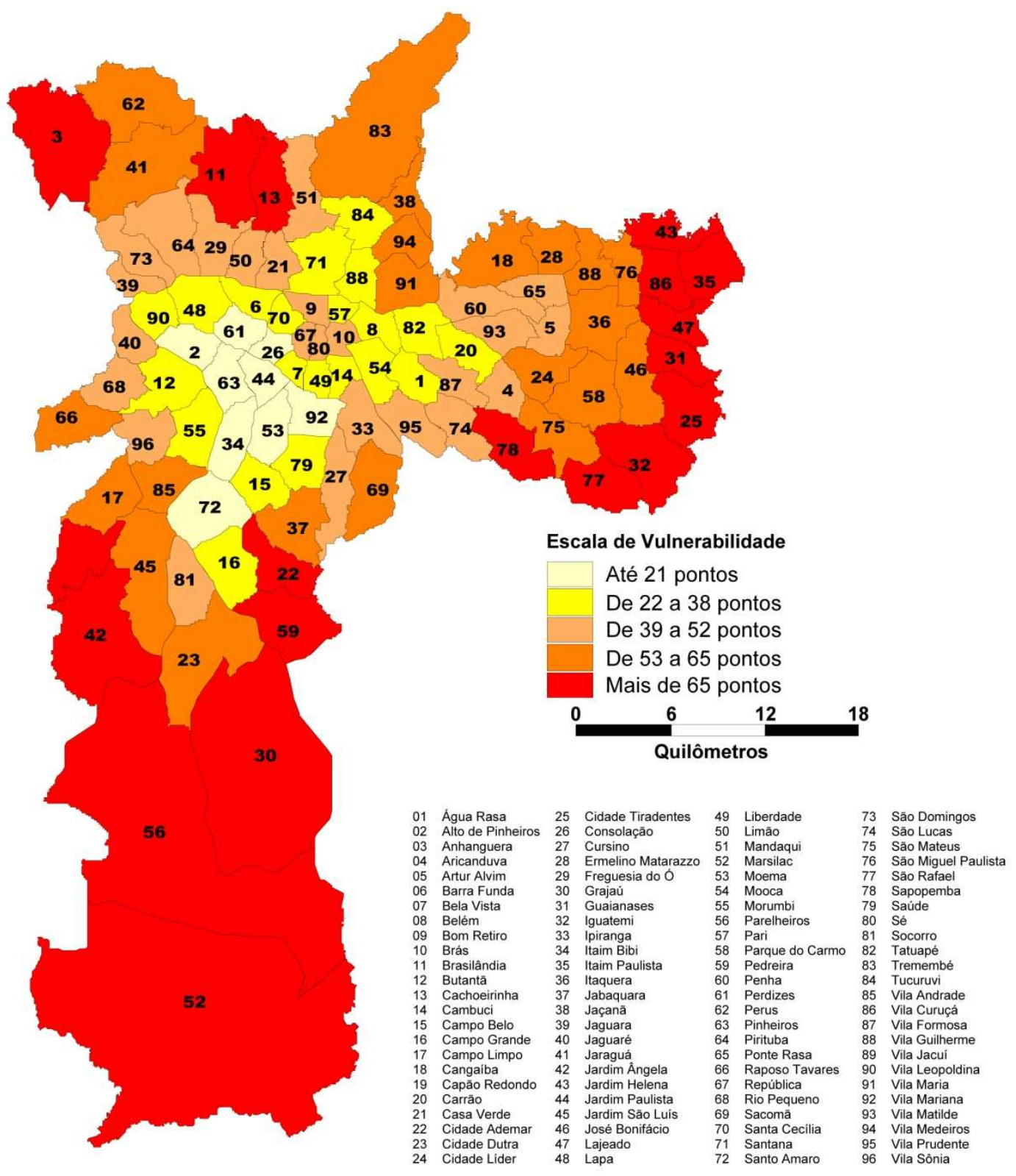

Fonte: Fundação Seade.

(1) O Índice de Vulnerabilidade Juvenil (IVJ), criado pela Fundação Seade, é calculado a partir da identificação dos fatores socioeconômicos e demográficos potencialmente capazes de afetar a vida dos adolescentes e jovens residentes nos distritos da capital. O IVJ varia em uma escala de 0 a 100 pontos, em que o zero representa o distrito com a menor vulnerabilidade e $100 \mathrm{com}$ a maior. Este índice pode ser resumido em cinco categorias, que agrupam os 96 distritos da cidade segundo níveis de vulnerabilidade: até 21 pontos (vulnerabilidade muito baixa); de 22 a 38 pontos (baixa vulnerabilidade); de 39 a 52 pontos (média vulnerabilidade); de 53 a 65 (alta vulnerabilidade) e mais de 65 pontos (vulnerabilidade muito alta). 


\section{Equipamentos Públicos em Cidade Tiradentes - Uma história de conquista dos moradores}

A conquista de equipamentos públicos de saúde e educação em Cidade Tiradentes partiu de um movimento dos moradores e de inúmeras ações de força e embate com as diversas gestões municipais. Os moradores, em entrevistas, são unânimes ao informar que o bairro, em sua fundação, não contava com equipamentos de saúde ou de educação suficientes. Caio Boucinhas participou de uma reunião de moradores que ameaçaram fechar as ruas do bairro e impedir a entrada de qualquer caminhão de mudanças até que escolas e postos de saúde fossem construídos no local. A negociação foi feita com a Caixa Econômica Federal, que financiava a construção, e as escolas foram construídas nos espaços que no parcelamento do solo foram destinadas a equipamentos públicos. O terminal de ônibus foi construído na sede da COHAB-SP na Fazenda Santa Etelvina. Para se ter uma idéia dos problemas de deslocamento, lembremos da distância com o centro da cidade: $35 \mathrm{~km}$, o que equivale a pelo menos duas horas de ônibus.

Enquanto alguns bairros negociavam na câmara, junto a vereadores, a presença de equipamentos públicos em áreas nem sempre regularizadas, em alguns bairros foi a pressão de movimentos sociais organizados quem conseguiu representatividade junto a órgãos públicos e fez das escolas, creches, postos de saúde e linhas de ônibus conquistas dos movimentos organizados.

Este é um dos capítulos da história da urbanização dos bairros periféricos na década de 1980. Mesmo num bairro todo produzido pelo Estado, como Cidade Tiradentes, não houve planejamento dos equipamentos públicos. A criação de escolas e postos de saúde, terminais de ônibus e demais serviços públicos foi resultado de um embate direto dos moradores, organizados em torno dos Núcleos Eclesiais de Base, movimento da Igreja Católica nos anos de 1980. 
Esta defasagem entre a política de habitação, o desenvolvimento econômico e social da cidade e a orientação dos investimentos públicos é o centro do conflito urbano que criou bairros segregados e modos de vida orientados por tensões diversas. A apropriação da cidade é diferente para cada grupo social, assim como o uso dos equipamentos urbanos e da estrutura viária, assim como também as representações e vivências da cidade são múltiplas. A política habitacional que foi gestada no período militar, como foi visto no primeiro capítulo, atendia a interesses do empresariado na conformação de recursos para a indústria e na produção de habitação que não onerasse tanto o trabalhador, de forma a manter salários baixos. Como vimos, a forma de produção de habitação mais barata para o trabalhador era o auto-empreendimento da casa própria pois era a sua própria força de trabalho, em forma de super-trabalho, que produzia as moradias. $\mathrm{O}$ custo da produção estava associado à compra do lote e à compra de equipamentos de construção, resultados de poupanças e restrições orçamentárias ao longo dos anos. Este mecanismo funcionou em épocas de altos índices de emprego (anos 1960 a 1980). Embora o auto-empreendimento da casa própria permaneça em loteamentos regulares, a sua grande expansão nos anos 1990 dá-se por meio de ocupações irregulares e favelamento.

Desta forma, a produção de habitação social no Brasil, após a crise do $\mathrm{BNH}$, obedeceu a políticas municipais, e não conseguiu suprir a demanda por moradias. Nas décadas de 1970 e 1980, assistimos ao crescimento das atividades de autoempreendimento da casa própria, num processo de depreciação dos salários, pois os trabalhadores usavam o seu tempo livre para a construção de suas casas desobrigando, desta maneira, que os salários dessem conta de prover a moradia. Àquela época, no final dos anos 1970 e nos anos 1980, estes bairros eram considerados distantes dos bairros urbanizados, não tinham infra-estrutura, nem atendimento à saúde básica, tampouco escolas. Eram bairros distantes dos empregos e o serviço de transporte público era precário. Foram os bairros que atraíram a força de trabalho incapaz de pagar os aluguéis nos bairros consolidados e no centro. Este processo de auto-empreendimento da casa 
própria na periferia sustentou e foi sustentado pela modernização fabril, por exemplo, da zona sul da cidade de São Paulo (mas não apenas). ${ }^{41}$

Ao longo das últimas duas décadas, bairros das regiões periféricas têm crescido e as relações sociais tornam-se cada vez mais tensas com a emergência de situações violentas. O horizonte de empregos que mantinha a urbanização de bairros nos anos 1980 cedeu lugar a uma indeterminação crescente que torna a urbanização um processo associado aos desdobramentos das vicissitudes econômicas. Por outro lado, a redução de um horizonte de emprego está relacionada à violência, mencionada acima. As práticas associativas, por exemplo, tornam-se cada vez mais ligadas à lógica gestionária e cada vez menos espaços de sociabilidade política (como nos anos 1980). A partir dos anos 2000 as práticas associativas estão cada vez mais relacionadas às instituições, por meio de convênios com as prefeituras, o que profissionaliza a atividade política e por isso mesmo arrefece sua potencialidade combativa, que era a tônica da experiência social que reunia as pessoas em torno das questões do bairro. Com a política profissionalizada, muitas pessoas afastam-se das discussões coletivas e voltam-se aos seus horizontes individuais, mediados pelas suas possibilidades de inserção no mundo do trabalho, cada vez mais restritivo, dadas as condições econômicas. O cenário urbano, palco destas relações, convida à observação e à reflexão. Estas dinâmicas sociais que configuram a cidade contemporânea foram estudadas nesta dissertação a partir da observação de relações sociais em Cidade Tiradentes, como se trata no capítulo 3, a seguir.

\footnotetext{
41 Atualmente o processo de crescimento da zona sul ilumina um aspecto muito impressionante do crescimento da cidade de São Paulo, que é o crescimento das periferias correlato à diminuição dos empregos. As alternativas de moradia se precarizam mais à medida que os empregos escasseiam e o trabalho torna-se eventual e mal remunerado.
} 


\section{Capítulo III - O espaço coletivo numa experiência etnográfica em um prédio da COHAB Cidade Tiradentes em São Paulo}

A opção pela etnografia reside na experiência da cidade, em suas diferenciações. Os discursos sobre as diferenciações urbanas são de natureza diversas, e geralmente orientados pela manutenção de alguma ideologia, que reforçam o processo de segregação sócio-espacial. Morar é também estar em relação com uma vivência da cidade, que é distinta para os distintos grupos sociais. Ao abordar um bairro da periferia, produzido pelo Estado, um dos aspectos evidentes deste processo é o estudo do papel deste Estado e de suas relações com o urbano, o que foi estudado nos capítulos precedentes. Por outro lado, o interesse da etnografia é conhecer estes trabalhadores conduzidos pelo Estado, vivendo em meio de suas mediações. Ao conhecer seu cotidiano, busca-se refletir sobre as questões urbanas contemporâneas, como as práticas da cidade e o espaço da política.

Este capítulo busca problematizar a experiência da política na contemporaneidade a partir do estudo da sociabilidade de famílias em suas relações com o espaço de um edifício, no maior conjunto habitacional da América Latina. Suas reflexões baseiam-se na pesquisa de campo realizada entre 2006 e 2008. 


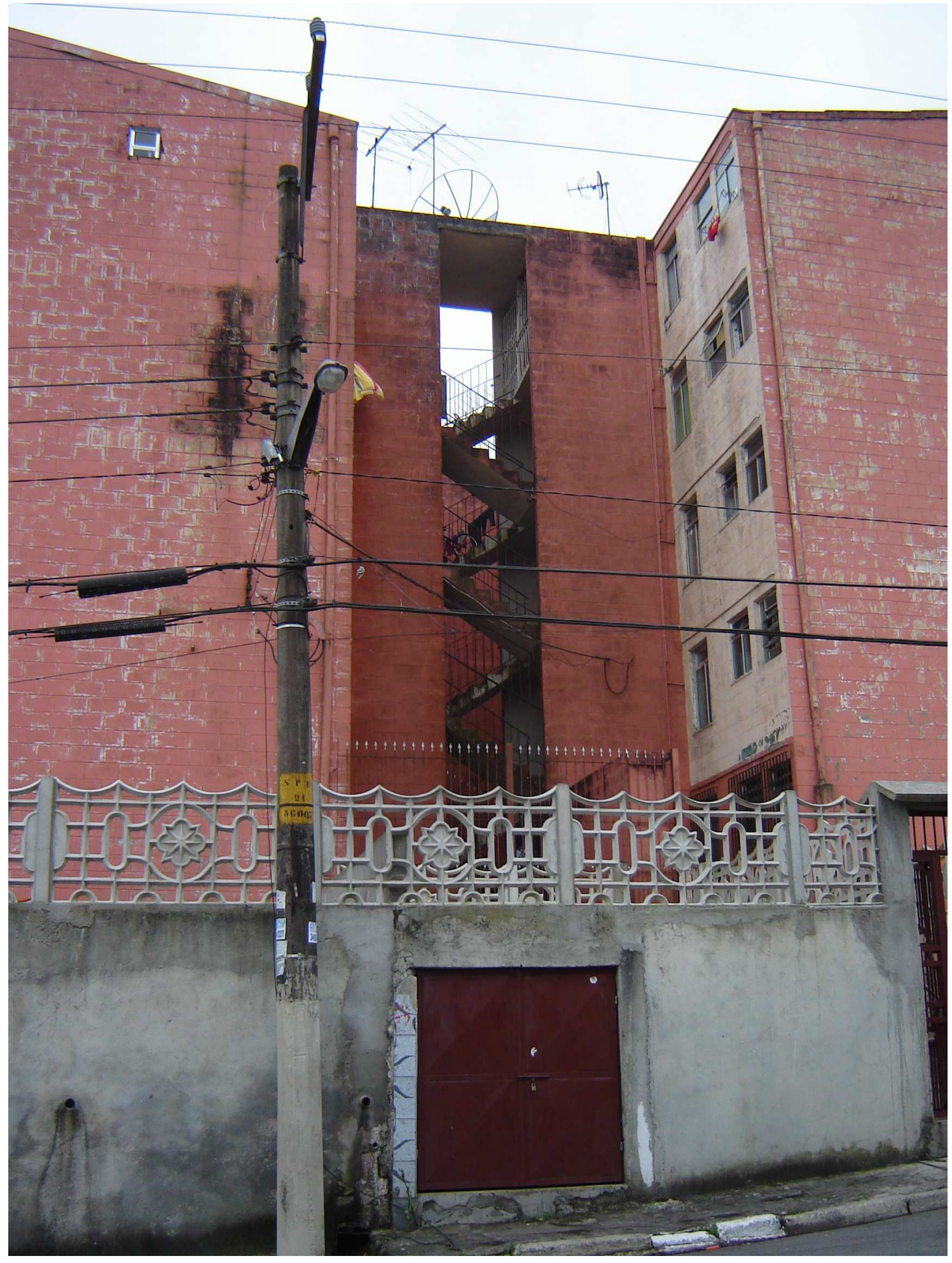

Edifício na Cidade Tiradentes.

Metodologicamente, a pesquisa baseou-se em entrevistas sobre trajetórias de vida. Os relatos das trajetórias de vida descortinam momentos significativos nas vidas dos indivíduos, em que se lêem estratégias de acesso ao mundo (no caso urbano 
contemporâneo, à moradia, ao trabalho, e à vida associativa). Um olhar para estas estratégias a partir de um grupo pequeno de entrevistas permite traçar dinâmicas sociais, as confluências entre as ações de Estado e ações dos trabalhadores, por exemplo. Ao refletir sobre o modo de vida contemporâneo, a partir das entrevistas e da etnografia, foi possível refletir sobre o "espírito de época", contrapondo-o em relação às pesquisas urbanas nas décadas de 1970-1980.

A opção pela análise do cotidiano de um único edifício surgiu da escolha metodológica de trabalhar com a etnografia micro-sociológica. Assim, se o objeto das sociabilidades comparece nesta pesquisa, ele é encarado de forma restrita neste trabalho, a partir de um recorte etnográfico muito preciso: o edifício. Evidentemente, as relações de sociabilidade na Cidade Tiradentes extrapolam em muito o aspecto condominial, mesmo porque nem todos vivem em edifícios. Mesmo entre os que vivem em edifícios, as relações de sociabilidade estão ligadas a vivências a partir de situações públicas (escolas, hospitais e postos de saúde), associativas (ONGs), religiosas (igrejas), de lazer e de esportes. A opção desta etnografia foi de trabalhar com um recorte, a saber, a experiência do espaço coletivo num condomínio, e como as relações de sociabilidade dos moradores com o entorno, além de sua atuação no mundo do trabalho, configura a visão acerca do que é coletivo entre os seus vizinhos. Ao mesmo tempo, ao olhar para este objeto restrito, buscou-se, a partir das micro-relações, e das trajetórias individuais, fazer inferências sobre o entendimento do que seja público, privado e coletivo, de como este conhecimento se constrói e de como ele orienta decisões e momentos coletivos.

A tradição da micro-sociologia ganhou peso nas ciências sociais a partir dos estudos de Goffman (2006), que analisou processos de interação social como cenas, e sujeitos sociais, como atores. Segundo esta abordagem, na interação, os atores buscam o convencimento a partir de atributos colocados na cena. Estes atributos estão ligados ao reconhecimento das características que definem o ator (sujeito social). A positividade que se atribui às características do sujeito revela a força deste papel social. Por meio dos atributos e das características colocadas em cena, é possível ler os sentidos de pertencimento ou distanciamento nas micro-relações. Estes pertencimentos e distanciamentos, por sua vez, denotam a capacidade de agregação de grupos sociais e 
sua inserção em contextos mais amplos. Estas cenas são montadas a partir da observação e dos relatos acerca do outro.

Este relato não é isento, pois numa situação de entrevista em que se discursa sobre si e sobre o outro, o entrevistado busca construir aos olhos do entrevistador uma imagem de si, que é situacional. A partir de sua leitura da situação de entrevista, o entrevistado busca identificação ou distanciamento do entrevistador, e isto diz sobre a construção de sua identidade.

Do ponto de vista da pesquisa social interessa, menos do que compreender os eventos de construção da identidade do entrevistador, compreender os atributos com os quais ele dialoga, expressões da situação social vivenciada por ele.

Por meio desta abordagem metodológica e conceitual a compreensão das teias sociais mostra-se ao observador. Estas teias são significados de formas da organização do trabalho (e, portanto, da produção), formas de organização política e religiosa, que podem ser entendidos a partir dos vínculos entre o mundo privado dos indivíduos e o mundo social. Na leitura do mundo privado dos indivíduos considera-se a mediação da família. $^{42}$

\section{Introdução metodológica}

O social é um jogo de posições em que a representação de individualidades biológicas se coloca. As representações sociais são manifestações do habitus ${ }^{43}$, ou seja, da acomodação de temporalidades pelas quais a individualidade se desloca. As posições que esta individualidade biológica assume estão asseguradas pelo reconhecimento

\footnotetext{
${ }^{42}$ A metodologia de investigação sociológica com famílias enriqueceu-se com o trabalho Cabanes (2006).

${ }^{43}$ O conceito de habitus está relacionado com a cristalização das práticas sociais: "Sem dúvida, podemos encontrar no habitus o princípio ativo, irredutível às percepções passivas, da unificação das práticas e das representações (...)”. Bourdieu (1996, p. 186).
} 
social, pela instituição de regras e normas de conduta assentadas na irredutibilidade do eu, sustentada pelo nome próprio. Ao narrar a sua história, o indivíduo buscará um sentido, a vida sendo contada como um caminho com significado, a partir de um projeto. O pesquisador, ao ouvir a história, compartilha da mesma ilusão de sentido que o narrador oferece. Este sentido resvala entre um discurso oficial (algo que se aproxima da posição da identidade jurídica do indivíduo) e a narração de confidências, oscilações discursivas a partir da posição que narrador-ouvinte assumem no momento da entrevista. Desta tessitura discursiva apreendemos, no campo da micro-sociologia, a cena dinâmica da vida cotidiana, posturas e falas que se encontram e se distanciam nos espaços comuns de um edifício tecendo aquilo que chamamos de vida cotidiana, imersa nas possibilidades de deslocamento mediadas pelos espaços e pelos tempos sociais.

O conjunto de entrevistas realizadas na Cidade Tiradentes respondia a inquietações comuns: em quais momentos das diversas trajetórias se colocava a decisão de morar ali para cada uma das famílias? O que representava para cada uma das famílias morar na Cidade Tiradentes? O que representava para cada uma das famílias as relações de vizinhança? Estas relações de vizinhança se traduziam na criação de um ambiente comum, com regras e propósitos? Quais seriam esses propósitos e/ ou estas regras? O que este ambiente comum (ou espaço coletivo) diz sobre a vivência da política em seus vínculos com a cidade no mundo contemporâneo? A apropriação rebaixada da experiência da arquitetura moderna é um motivador de experiências políticas, como se pretendia a vanguarda modernista, ou, ao contrário, uma maneira de arrefecimento da experiência coletiva?

Uma análise da experiência urbana da Cidade Tiradentes, como esboçada no capítulo 2, pode levar à conclusão de que a proposta dos conjuntos habitacionais é uma apropriação rebaixada da arquitetura moderna. A proposta de habitações mínimas adveio das experimentações realizadas pelos modernistas europeus no início do século XX, período de intenso desenvolvimento da industrialização e expansão do operariado. Segundo Kopp apud Silva (2006):

"O habitat operário (...) não é produto do acaso mas fruto de estudos aprofundados sobre a maneira mais rentável de alojar o maior número de trabalhadores em um espaço tão reduzido quanto possível”. 
A inspiração modernista estava ligada à busca da superação da situação precária das moradias após a $1^{\text {a }}$ guerra mundial, e às crescentes transformações urbanas e tecnológicas da época. São temas presentes nos estudos de arquitetos como Walter Gropius e Bruno Taut. ${ }^{44}$. A standartização da habitação popular e a produção industrial dos componentes da habitação passam a ser uma realidade da arquitetura mundial, que persegue os propósitos da funcionalidade e da economia. Por outro lado, a proposta modernista estava em consonância a um novo ideal de homem e de humanidade: ao homem moderno cabia uma moradia moderna e funcional, cujo espaço privado fosse mínimo e cuja vivência pública (no trabalho, em equipamentos de lazer e em equipamentos de serviços) fosse maximizada.

\begin{abstract}
"Do projeto do mobiliário ao dos assentamentos humanos tudo está vinculado a um novo projeto de sociedade. A idéia da casa como uma "máquina de morar" estava alinhada com o pensamento tecnisista e a standardização propostas para o homem da era da máquina." Silva (2006, p. 22)
\end{abstract}

De modo consciente ou inconsciente, a apropriação das máximas da arquitetura moderna pela arquitetura de interesse social brasileira desdobrou-se ao longo de toda a sua história e lê-se na preocupação com a redução de custos, a industrialização do processo construtivo, a standartização dos projetos e projetos baseados em habitações pequenas (atendendo às necessidades básicas) e grandes espaços de uso coletivo. (Bonduki, 2004). No caso brasileiro, a experiência do traçado modernista em algumas

\footnotetext{
44 "O programa de May baseava-se no acesso de todas as unidades ao sol e a ventilação e na facilitação das atividades domésticas. A configuração dos espaços também pretendia diminuir os incômodos entre os moradores que conviveriam mais próximos. Não existe mais a estratificação da casa burguesa, as atividades domésticas são assumidas pela mulher que não possui empregados. A cozinha higienizada tem seu funcionamento otimizado. O espaço gerado é resultado do estudo das atividades humanas dentro do espírito do existenzminimum. Assim, vários equipamentos passam a ser móveis ou escamoteáveis como camas e mesas, armários são embutidos e podem dividir os ambientes e as portas podem correr. $O$ resultado é a considerável redução da área habitada com apartamentos de 40m2 a $65 m_{2}$ e área média por ocupante de $10 \mathrm{~m}$. A maioria dos equipamentos, assim como os elementos construtivos, lajes, paredes e vigas serão pré-fabricados em usinas a partir de normas específicas. A tipificação das propostas deve atender ao princípio de igualdade com qualidade." Silva (2006, p.17-18). Gropius foi nomeado diretor da Bauhaus, escola de Artes e Arquitetura alemã que muito influenciou a arquitetura no início do século XX. Outro arquiteto, Ernest May, também concebia a habitação unifamiliar baseada na funcionalidade e na economia de custos, como formas de vencer o déficit habitacional que assolava a Alemanha (experiência similar à Inglesa). O tema da habitação mínima foi discutido no Congresso Internacional de Arquitetura Moderna de 1929 em Frankfurt
} 
obras, culminou com a privatização de áreas coletivas, revelando a inadequação de um modelo individualista para uma realidade em que a família nuclear é extensa. De fato, ao analisar a realidade de um edifício, verifica-se a presença intensa de membros da mesma família no mesmo edifício, e a circulação de famílias entre os apartamentos ao longo do tempo. Embora a política seja pública e universalista, na prática, a tendência de proximidade espacial das famílias na periferia é bastante grande, seja nos quintais seja num edifício de apartamentos.

A concepção modernista de habitação mínima baseava-se em uma idéia de libertação do homem, que estava atrelado à casa por sua funcionalidade, apenas. Os espaços privados, diferentemente da experiência burguesa, eram mínimos. Esta configuração espacial está imbuída da idéia da superação da afetividade burguesa, mas, em realidade, seus resultados resvalaram para a experiência da coerção social por meio do espaço e da supressão das individualidades por meio do processo de coletivização.

Cidade Tiradentes é uma experiência rebaixada da estética modernista, pois apropriou-se somente de seus fundamentos econômicos: a redução dos custos e a padronização dos projetos, sem a contrapartida da dimensão e da experiência dos espaços públicos. Como vimos no capítulo 2, embora abundassem espaços vazios em Cidade Tiradentes, escasseavam serviços públicos e obras de uso coletivo. Ao longo dos anos alguns equipamentos públicos de grande monta foram construídos no bairro, como os Centros de Educação Unificados - CEUS e o Hospital Municipal de Cidade Tiradentes (propostos na gestão Marta Suplicy entre 2001-2004), mas não chegam a consolidar o espírito de monumentalidade dos espaços públicos propostos, por exemplo, por Le Corbusier.

Nas palavras de Recamán (2004, p. 19):

"A questão habitacional passará a ser tratada como uma questão de planilha de custos, investimentos e rentabilidade, e não de projeto ou arquitetura, muito menos, construção de cidades.

Os mega-conjuntos populares que vão surgir a partir dos anos 60 são frutos de um processo técnico-positivista tímido que avançou lentamente em paralelo ao desenvolvimento do mainstream da nossa 
arquitetura, e que ganhou força com o golpe militar. Correspondem à coetânea explosão imobiliária dos edifícios residenciais de classe média, que seguem a mesma lógica da alta lucratividade. Reservada para outros fins, a arquitetura pompier dos grandes palácios públicos conviveu com esse tecnicismo hipertrofiado do cálculo financeiro, reproduzindo um divórcio pré-moderno, agora sem perspectivas de superação. A técnica retórica do virtuosismo estrutural, característica primeira da arquitetura moderna brasileira, é sublimação de sua excepcionalidade antisocial,de sua irreprodutibilidade fetichista. A cidade brasileira é a composição desses movimentos, que não se excluem, antes se complementam."

\section{Espaço Coletivo - Entre o Espaço Privado e o Espaço Público}

O espaço urbano de Cidade Tiradentes é um espaço que foi totalmente planificado. A abertura de vias e a construção de edifícios foi planejada, realizada e documentada pela COHAB-SP. Como visto, a maior parte dos espaços é de propriedade da própria $\mathrm{COHAB}-\mathrm{SP}$, divididos em áreas verdes, áreas públicas vazias, áreas públicas destinadas a equipamentos públicos, edifícios e "embriões". Nos últimos anos, a situação dos maiores empreendimentos comerciais foi regularizada via licitação para compra de terrenos. Estes espaços, contudo, são em pequeno número. O comércio da região é realizado por pequenos comerciantes, que abrem suas garagens para estas atividades.

Do ponto de vista estritamente físico, o espaço público de Cidade Tiradentes são as ruas e os edifícios que constituem os equipamentos públicos (escolas, postos de saúde, hospital, sacolão) e as pequenas praças localizadas em alguns quarteirões. O espaço privado é constituído pelas casas e apartamentos e o espaço coletivo é constituído pelos espaços de uso coletivo dentro dos edifícios. Cada edifício possui uma área livre para convivência e circulação, que inclui as escadarias.

Do ponto de vista conceitual, no entanto, o espaço público, o espaço privado e o espaço coletivo são abstrações que operam na dinâmica das relações sociais, e configuram nossa compreensão acerca do que é comum, do que é coletivo e do que é privado. 
O espaço público tem sua gênese na polis grega, segundo Arendt (2008). O fundamental na concepção arendtiana do espaço público é que ele diz respeito à participação de todos os cidadãos na reflexão sobre o destino comum. O mundo comum, tal qual existia na Antiguidade, baseava-se na premissa de que é algo que os homens adentram quando nascem e deixam para trás ao morrer, algo que os transcende, mas que ao mesmo tempo os impele a existir concretamente. Sua força política consiste em sua perenidade, pois os homens se colocam nele preocupados com sua imortalidade.

$\mathrm{Na}$ análise de Arendt (2008) o mundo comum foi substituído por outras experiências, como a experiência religiosa e a mediação da mercadoria e da propriedade. A autora, refletindo sobre a obra do economista Adam Smith, observou que a recompensa pecuniária pelo reconhecimento público provoca a quebra da garantia contra a futilidade, garantia esta que está na raiz do mundo público. A recompensa pecuniária passa a ser a motivação para o reconhecimento público, e não a preocupação com a imortalidade. O conflito passa a ser a base para interesses individuais, e não um campo de debates em que se busca o bem comum.

Com o capitalismo, o trabalho passa a ser a mediação fundamental das relações sociais. Com o final do welfare state e a emergência do chamado "desemprego estrutural", a sociedade torna-se uma sociedade de trabalhadores sem trabalho. A busca por sentido e significado passa a ser cada vez mais individualizada e o que há no lugar da esfera pública é o que Rancière (1996) chamou de cacofonia. É como se a experiência dos indivíduos, mediadas pelas trajetórias de suas famílias, fossem ininteligíveis no sentido público ${ }^{45}$. A inteligibilidade é dada apenas pela mediação que é comum: a mercadoria. A medida dos destinos comuns passa a ser a medida da

45 Para Arendt (2008) a dissolução do mundo comum está relacionada com a perda da inteligibilidade entre os homens. Nas palavras de Telles (1999, p. 39): “Antes de mais nada, a dissolução desse espaço público significa a perda de um ' mundo comum' que articula os homens numa trama feita por fatos $e$ eventos tangíveis em seu acontecimento, construindo as referências cognitivas e valorativas de um horizonte comum e uma interlocução possível. É uma trama construída pela interação entre os homens e na experiência da pluralidade humana através da qual as opiniões se formam e os julgamentos se constituem. Nesse caso, a dissolução do espaço público significa a perda de um espaço comum entre os homens, comprometendo esta capacidade de discernimento que a compreensão e o julgamento exigem, enquanto ' maneira especificamente humana' de se fazer a experiência da realidade." 
mercadoria, o trabalho torna-se um meio para a conquista da mercadoria e a ação do homem em todos os campos relaciona-se com a esfera mercantil ${ }^{\mathbf{4 6}}$.

O mundo público e o espaço público esvaziam-se. Habermas (1984) localiza a gênese da esfera pública na sociedade burguesa, e também chega à mesma conclusão quanto à supressão deste espaço na contemporaneidade. Na visão do autor a esfera pública burguesa, que foi criada nos salões burgueses, nos clubes, nas dimensões associativas das cidades, e expandiu-se com a criação da imprensa, entrou em declínio a partir do século XIX com a intervenção estatal minando a autonomia burguesa e com a transformação da imprensa em empresa capitalista, concomitantemente à formação da indústria cultural. De público pensador de cultura, o público torna-se consumidor de cultura. A esfera pública perde a sua potencialidade política, entendendo-se política como a capacidade humana de criação de significados públicos, para transformar-se em legitimadora de um consenso pré-fabricado.

\begin{abstract}
"Se as leis do mercado, que dominam a esfera do intercâmbio de mercadorias do trabalho social, também penetram na esfera reservada às pessoas privadas enquanto público, o raciocínio tende a se converter em consumo, e o contexto da comunicação pública se dissolve nos atos estereotipados da recepção isolada." Habermas (1984, p. 191).
\end{abstract}

Ao mesmo tempo, os indivíduos deixam de refletir sobre questões comuns e passam a ocupar-se apenas de questões privadas. Se a esfera pública burguesa foi criada dentro do campo literário, dentro do tempo livre dos burgueses, na sociedade contemporânea o próprio tempo de lazer permanece vinculado ao tempo de trabalho e por isto mesmo à vida privada dos indivíduos ${ }^{47}$.

46 Do ponto de vista da pesquisa de campo o fundamental é observar a realidade, escutar as trajetórias e se questionar a todo tempo pelos sentidos que elas colocam, buscando evocar o que se coloca entre os indivíduos e entre as famílias que possa se deixar entrever processos de resistência ou de busca de uma "vida que valha a pena ser vivida", para citar Arendt (2008).

47 A dissolução da esfera pública burguesa apresenta-se também em sua dimensão institucional: o parlamento torna-se espaço de representação de interesses, ao contrário do papel de dignatário de uma lei genérica de bem comum que pressupunha a discussão pública prévia. Assim também é possível observar a transfiguração do papel da esfera pública política através da mudança do papel do voto - se antes ele era 
"Se o tempo do lazer permanece preso ao tempo do trabalho como seu suplemento, nele só pode ter continuidade a persecução dos negócios privados de cada um, sem poder converter-se na comunicação pública das pessoas privadas entre si." Idem, p. 190.

\section{A experiência de campo e a gênese de um conceito: o espaço coletivo}

As trajetórias corroboraram a visão de que o mundo comum fragmentou-se em núcleos de sentidos compartilhados dentro da experiência privada dos indivíduos, isto é, no campo da necessidade, em que a reflexão é mediada pelas alternativas individuais dais quais se pode lançar mão. A ação coletiva é minimizada como alternativa para a construção de outras possibilidades para o mundo público. Numa experiência de necessidade, a percepção do mundo público surge a partir do entendimento da restrição de oportunidades. Numa experiência de liberdade, ao contrário, a ação do sujeito é emancipadora, ou seja, é de criação de sentido no mundo público. Este sentido de necessidade, por seu turno, é produzido socialmente, por meio de um "espírito de época" que valoriza o consumo e orienta a conduta de todos os indivíduos neste sentido.

Se, por um lado, podemos observar as trajetórias dos indivíduos mediadas por suas famílias, entre o mundo do trabalho que não constrói uma solução coletiva redentora (que em algum momento surgiu no horizonte, ainda que tenha sido para um grupo restrito, que eram os operários do $\mathrm{ABC}$ paulista), ou o mundo da habitação que cria obstáculos a todo tempo (afirmando que para acessar um lugar privado no mundo público é necessário dominar os códigos deste mundo público, compreensão esta que é negada pela trajetória de trabalho que o sujeito teve possibilidades de construir), é necessário argumentar que a história é um campo aberto e que estes tempos sociais

\footnotetext{
“apenas o ato conclusivo de uma disputa contínua, feita publicamente, entre argumentos e contraargumentos" Habermas (1984, p. 47), agora ele transforma-se em uma "encenação" em que a emergência da opinião não pública aparece com a publicidade política através da manipulação do inconsciente a que faltaria os pressupostos de autonomia e racionalidade de uma opinião pública.
} 
construídos coletivamente podem pautar transformações. A interpretação deve ao mesmo tempo reconhecer os obstáculos e as potencialidades da transformação.

Se a linguagem do direito social se esvaziou de sentido com a experiência mundial de destituição dos direitos, se a linguagem do socialismo se esvaziou de sentido com a desilusão mundial da apresentação de experiências autoritárias e antidemocráticas, se a linguagem do trabalho como possibilitador de mediações concretas e conquistas de classe se esvaziou com a onda neoliberal, e vemos o consumo mediar as experiências coletivas, os tempos que correm devem sussurrar novas linguagens que venham a fazer da experiência da vida frente aos imperativos da servidão financeira ${ }^{48}$ algo que valha a pena ser vivido, para retomar a expressão arendtiana. Seja no campo da transmissão geracional de valores da dignidade humana, seja na experimentação de relações de gênero mais eqüitativas ${ }^{49}$, seja na transmutação dos afetos pela experiência religiosa, seja na crença na reverberação através das instituições de valores mais libertários, de algum modo nossa escuta às potencialidades deve estar atenta, informada todo o tempo pelos limites concretos da experiência contemporânea, mas consciente de sua humanidade.

Entre a experiência de privação dos indivíduos, a experiência privada que é medida pela família, em seus afetos e no provimento destas necessidades, e a experiência pública com o mundo, foi delimitado um espaço de intermediação que foi chamado de espaço coletivo, dentro do campo de pesquisa: um edifício no conjunto habitacional Santa Etelvina, em Cidade Tiradentes. Este espaço coletivo é o encontro dos moradores na cotidianeidade, e é materializado pelos espaços físicos comuns no edifício.

Se o mundo público no sentido arendtiano ou mesmo habermasiano se esvaziou, é certo que os indivíduos têm uma experiência com o mundo que é mediada pelos outros homens, suas instituições, sua história e suas determinações. Ele traz em seu bojo

\footnotetext{
${ }^{48}$ Sobre o conceito de servidão financeira ver Paulani (2008).

${ }^{49}$ Sobre relações de gênero ver Cabanes (2006).
} 
suas próprias experiências, afetivas, mentais e cognitivas, dialogando a todo o tempo com o mundo que o recebe no trabalho, na escola, no bairro, no prédio.

O espaço coletivo tratado, assim, como o espaço situacional em que os indivíduos se reconhecem e criam sentidos comuns, a partir dos quais a ação no mundo público se orienta. É um espaço que tem existência concreta e também subjetiva ${ }^{\mathbf{5 0}}$. Materializado na idéia de condomínio, o espaço coletivo perpassa a visão que um sujeito faz do outro, do seu vizinho. Esta visão do outro é informada pelo mundo público, em diálogo com o mundo privado. Os valores de um sujeito se constroem nesta relação e são o estofo para os julgamentos que se fazem do outro. Dada a sua natureza de local comum, o espaço coletivo é objeto de julgamentos e ações. A gestão do condomínio é sua expressão direta. Esta gestão demanda que os sujeitos voltem a sua atenção para o que é comum a todos de forma imediata: a organização em torno do consumo de água e luz e a organização em torno da manutenção e da limpeza do espaço comum. Para que estas ações aconteçam pressupõem-se providências coletivas: a eleição de uma pessoa para síndico, a elaboração de um estatuto, a realização de reuniões de condomínio, a reação diante de eventualidades. O síndico, por sua vez, está no papel de mediador entre todos: é por meio de sua equipe que serão contabilizados os gastos com a água e que o controle do orçamento comum Se esta é uma realidade cotidiana para todos os que têm experiência em compartilhar um espaço físico comum, a investigação destas ações nos informa sobre o que os sujeitos pensam que é coletivo e o que orienta a decisão sobre o que é coletivo. O espaço coletivo situa-se entre o mundo público, cuja potência foi esvaziada, (o mundo da ação e da reflexão sobre o que é comum) e o mundo social (em que as necessidades são compartilhadas) ${ }^{\mathbf{5 1}}$. Desta forma,

\footnotetext{
${ }^{50}$ E neste sentido a noção de espaço coletivo aproxima-se do conceito de espaço público em que "a singularidade de cada um é reconhecível e pode ser reconhecida. (...) Trata-se de uma singularidade construída através da ação e do discurso - e através da ação e da palavra, diz Hannah Arendt, que os homens se deixam ver e reconhecer na sua individualidade.” Telles (1999, p. 50).

${ }^{51}$ Arendt (2008, p. 50) localiza a emergência da esfera social com a emergência da relação de propriedade mediando todas as relações humanas, e o governo tornando-se administração para proteger os bens. Sobre a emergência da sociedade ela dirá: "Um fator decisivo é que a sociedade, em todos os seus níveis, exclui toda a possibilidade de ação, que antes era exclusiva do lar doméstico. Ao invés de ação, a sociedade espera de cada um dos seus membros um certo tipo de comportamento, impondo inúmeras e variadas regras, todas elas tendentes a 'normalizar' os seus membros, a fazê-los 'comportarem-se', a abolir a ação espontânea ou a reação inusitada."
} 
investigar o espaço coletivo nos permite descrever o que existe no mundo social. Esse mundo social é, para Arendt (2008), uma corruptela do mundo público.

O relacionamento entre os moradores diz muito sobre o poder a que estão assujeitados e que reproduzem no momento da gestão do espaço coletivo. As ações coletivas e as omissões revelam visões de mundo e formas de inserção no social. $\mathrm{Na}$ história deste condomínio, lemos a história recente dos universos do trabalho, da moradia, do consumo e da religiosidade na periferia da maior cidade brasileira. As trajetórias são significativas, pois estão inseridas na dinâmica dos acontecimentos sociais. Mais do que isto, os destinos individuais e sociais se encontram. A trajetória individual está inserida nos cruzamentos das dinâmicas sociais, mas também orientam essas dinâmicas sociais. ${ }^{52}$

\section{Condomínios na COHAB: gestão ou disciplinamento}

O arquiteto Nakano (2002) realizou um trabalho sobre a experiência do disciplinamento nas $\mathrm{COHABs}$ a partir das relações de poder nos condomínios. Tomou os elementos de ancoragem em Foucault, para quem a coerção se inscreve nos corpos por meio do espaço disciplinar. Foucault (1997). Para Nakano (2002), os espaços nas COHABs são pensados como espaços que disciplinam os corpos e promovem a coerção da espontaneidade dos sujeitos. Foucault (1997) estudou presídios, manicômios e outros espaços sociais e demonstrou que sua configuração espacial está baseada na coerção dos corpos.

Segundo Nakano (2002), o espaço disciplinar das unidades habitacionais da COHAB-SP caracteriza-se pela padronização, e pela forma como o uso é condicionado: o órgão público disciplina uma unidade habitacional para cada família, enquanto nas favelas, por exemplo, são comuns espaços de interligação. $O$ autor avalia que a padronização dos conjuntos habitacionais marca uma diferenciação na paisagem tanto

\footnotetext{
${ }^{52}$ Esta é uma idéia forte em Cabanes (2006).
} 
quanto a padronização de um condomínio de luxo. No caso das COHABs, no entanto, a padronização é estigmatizante, ao passo que na relação do transeunte e do cidadão com o condomínio de luxo ela está calcada na idéia de distinção e distanciamento, atestando o status dos que vivem ali.

Os moradores têm direito de uso ao seu apartamento unifamiliar. $\mathrm{O}$ espaço do entorno do prédio é um espaço de uso coletivo, e a decisão sobre sua apropriação é da gestão do condomínio. A esta apropriação Nakano (2002) chamou de tática de territorialização. Essas táticas, quando expandidas para além dos limites do espaço de uso comum, podem ser entendidas como contra-condutas.

Os moradores se apropriam do espaço e criam suas próprias regras a partir desta apropriação. Os edifícios são entregues sem as garagens, que são construídas pelos moradores. As garagens, apêndice ao apartamento, são negociadas como valor de uso e como valor de troca. Como mercadoria, tornam-se um espaço apropriado, geralmente, como forma de produção de renda: pequenos comércios são montados, em que são vendidos produtos como alimentos, brinquedos, roupas, e são oferecidos serviços como os de cabeleireiro. Além disso, muitas garagens são usadas como mini indústrias. No edifício em que foi realizada a pesquisa, a atividade predominante nas garagens é a produção de tapioca, iguaria característica do nordeste brasileiro.
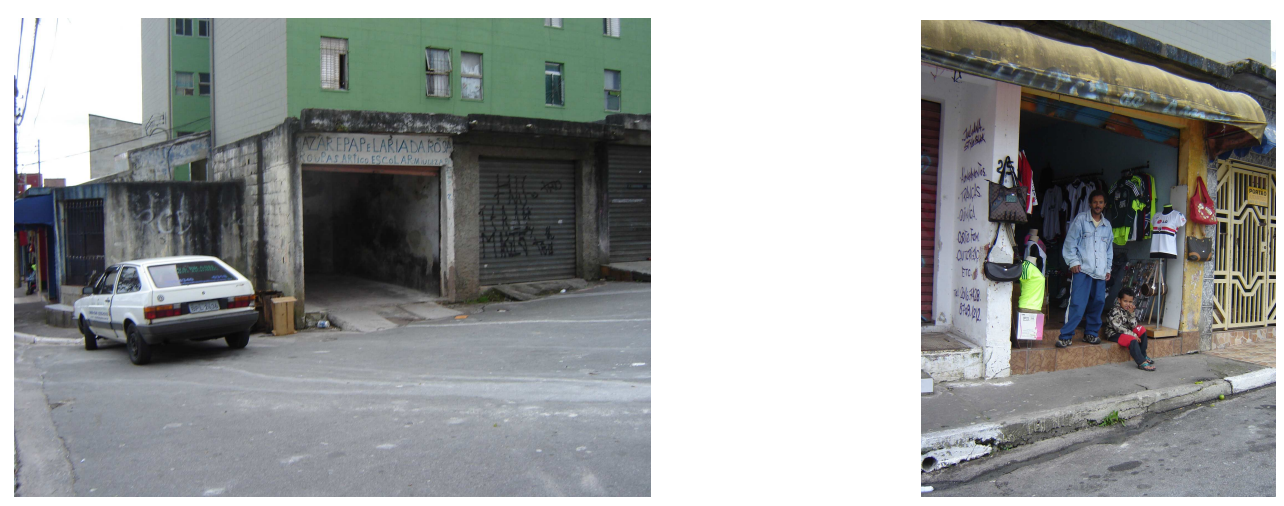

Garagens construídas pelos moradores: uso como garagens e uso comercial, ambos usos não permitidos pela COHAB-SP.

O uso dos edifícios é estritamente residencial, segundo a COHAB-SP. Os moradores também se apropriam da lógica da propriedade e negociam os apartamentos 
e as garagens, alugando-os, vendendo-os e comprando-os, mesmo enquanto são ainda mutuários.

A apropriação dos espaços é restrita às possibilidades arquitetônicas e às possibilidades de tomadas de decisão coletivas sobre os espaços de uso comum. Para esta gestão, a COHAB-SP preparou um Manual de Condomínios, orientando os moradores sobre a gestão do condomínio. Os técnicos da COHAB-SP partem do entendimento de que os moradores não têm experiência em condomínio, e que muitos vêm da experiência de favelas. O objetivo deste material, segundo Nakano (2002), é o disciplinamento dos corpos dos moradores:

"No modelo apresentado, a função disciplinar deste regulamento é manifesta no terceiro parágrafo onde se determina que " os condôminos deverão - por si, seus familiares, dependentes, serviçais, hóspedes ou visitantes - observar sempre os preceitos da boa moral e dos bons costumes, respeitando as normas que tutelam o direito de vizinhança, abstendo-se da prática de quaisquer atos que possam prejudicar a segurança e o bem-estar comum, evitando-se, portanto, o uso nocivo da propriedade'." COHAB/SP, s/d, 7 apud Nakano (2002, p. 137). ${ }^{53}$

53 Nakano (2002, p.138) transcreve o sétimo parágrafo do Manual dos Condôminos, em que regras extremamente restritivas são colocadas aos moradores. Na prática, nenhuma dessas medidas foi respeitada ou sequer houve qualquer punição ao desrespeito às normas. As regras de conduta evidenciam muito mais a postura autoritária e distante da realidade dos moradores do que propriamente um instrumento de auxílio na gestão coletiva. A leitura de algumas normas deixará este ponto claro:

“7º - É expressamente vedado aos condôminos:

A - Mudar ou alterar as fachadas de seus respectivos apartamentos;

B- Decorar ou pintar paredes, janelas, esquadrias externas, etc., de maneira que modifique o aspecto arquitetônico do edifício que integra o condomínio;

C - Afixar cartazes, anúncios, letreiros ou quaisquer placas nas fachadas e partes externas do apartamento, nas entradas e corredores comuns de acessos às mesmas, bem como em qualquer outra parte ou dependências comuns;

D - Instalar toldos externos ou qualquer outro equipamento nas janelas, assim como colocar, ou permitir que se coloquem, nas partes comuns do edifício quaisquer objetos ou instalações, sejam de que natureza forem;

E - Sem prejuízo das proibições gerais referentes à locação e cessão dos apartamentos - constantes do título aquisitivo - alugá-lo ou cedê-los, no todo ou em parte, para: pessoas de maus costumes, clube de jogos ou dança, reuniões políticas, escolas de música, entidades que exerçam atividades ruidosas, depósito de objetos, enfim, dar aos apartamentos qualquer outra finalidade que não estritamente 
Nakano (2002) analisa o documento de forma literal. É necessário, contudo, um certo distanciamento para relativizar o seu papel no dia-a-dia dos moradores. Com

residencial, sendo igualmente vedado dividir a unidade autônoma com o fim de aliená-lo a mais de uma pessoa;

F - Limpar ou remover pó de tapetes, cortinas, bem como das dependências dos apartamentos, de modo a perturbar e causar incômodo aos demais condôminos;

$\mathrm{G}$ - Estender roupas, tapetes ou quaisquer outras peças ou objetos nas janelas, bem como colocar objetos em lugares onde estejam expostos ao risco de cair;

H- Lançar pelas janelas ou outros locais, objetos de qualquer natureza, líquidos, papéis, detritros, etc, às vias públicas ou internas, áreas verdes, passeios, calçadas, áreas internas e demais dependências do condomínio;

I - Colocar ou depositar lixo, detritos, etc. em outros locais que não coletores e depósitos destinados a este fim;

J - Manter nos apartamentos, ou em qualquer parte do edifício, substâncias, produtos, assim como instalar aparelhos que causem risco à segurança e solidez do prédio, ou incômodo aos seus moradores e aos demais condôminos;

$\mathrm{K}$ - Sobrecarregar, com peso superior à sua capacidade, a estrutura e as lages do edifício;

L - Usar rádios, vitrolas, alto-falantes ou quaisquer outros instrumentos sonoros, acústicos e musicais, em volume de som que possa perturbar os vizinhos;

M - Fazer ou provocar barulhos de qualquer natureza, notadamente depois das 22 (vinte e duas) horas;

$\mathrm{N}$ - Utilizar os empregados e serviçais do condomínio para serviços particulares;

O - Manter nos apartamentos cães, gatos, ou qualquer outros animais, com exceção de pássaros que não perturbem a vizinhança;

$\mathrm{P}$ - Utilizar as entradas, as rampas e corredores de acesso aos apartamentos, bem como as áreas internas, térreas, cobertas e demais dependências de uso comum, para a guarda ou depósito de quaisquer coisas ou objetos, sob pena de imediata remoção pelo síndico ou subsíndico, por conta e risco do responsável, e sem prejuízo de multa ou sanção cabível;

Q - Intervir ou de qualquer forma influir nas redes, fiações, ligações, instalações, pontos de iluminação, registros, medidores e demais equipamentos gerais de água, luz, esgoto e telefone, como também deixar de pagar tais taxas, sujeitando-se às medidas cabíveis por parte das concessionárias desses serviços públicos, devendo sempre serem levados ao conhecimento do síndicos, as irregularidades de funcionamento que venham a ocorrer, ficando os condôminos exclusivamente responsáveis pelos reparos nas bombas de sucção de água;

R- realizar quaisquer mudanças ou transferências de móveis ou outros objetos, volumosos ou pesados, sem aviso prévio ao síndico e no período noturno; $\mathrm{S}$ - Praticar quaisquer outros atos que constituam violação do estabelecido no presente regulamento e no contrato aquisitivo." (COHAB, s/d: 8-9 apud Nakano 2002, p. 138-139). 
efeito, da mesma forma que um regulamento de condomínio de classe média, as normas são usualmente exageradas e nem sempre são cumpridas. A especificidade deste caso é o desconhecimento dos moradores acerca do documento, e a ausência da COHAB-SP no apoio aos condôminos e síndicos.

A COHAB-SP, por outro lado, tem uma visão dos moradores como incapazes de organização coletiva e de gestão do espaço coletivo. Uma técnica da COHAB-SP, durante entrevista, lamentou a ausência de cursos específicos para os moradores. À exceção de algumas poucas experiências na gestão Erundina (1989-1992), a COHABSP não realizou cursos ou atividades para preparar os moradores para sua nova vida de condôminos, disse a técnica. Em sua visão, os moradores trazem a experiência da favela cujos contornos de atuação são distintos da vida em condomínio. No entanto, o próprio órgão não mantém registros sobre os moradores, sua origem ou qualquer tipo de acompanhamento. Sua relação com os moradores é quase fiscalizatória, sobretudo no que diz respeito ao financiamento dos apartamentos. A intervenção da COHAB-SP nas questões condominiais é restrita, e só ocorre quando provocada pelos moradores.

A experiência de viver em condomínio revela dificuldades: desentendimentos e conflitos que redundam em atraso nas contas, cortes de abastecimento e, sobretudo, a convivência com uma das facetas da violência urbana: o tráfico de drogas na sua face de crime organizado.

Em relação aos contratos de gaveta, apesar da proibição, os novos moradores sempre conseguem regularizar, com um contrato na mão, sua relação com a COHABSP. A inadimplência raramente é cobrada e, eventualmente, anistias são concedidas. As mudanças de gestões municipais tornam as relações pouco claras para os moradores, pois os critérios de cobrança, valores de prestações e critérios de regularização mudam a cada nova administração. Os moradores vêem a COHAB-SP como um órgão fiscalizatório, e não como um apoio nos problemas condominiais ou cotidianos. Quando estava fotografando no bairro, a autora foi interpelada por uma comerciante com evidente preocupação “A sra. não é da COHAB ou da prefeitura, é??” 


\section{Mediações para o espaço coletivo: entre o público e o privado}

Muitos de nossos entrevistados conheceram o mundo do trabalho antes do mundo escolar. No sertão nordestino, onde nasceram ${ }^{\mathbf{5 4}}$, o mundo que os recebia era a roça, a religião e a necessidade do trabalho. O mundo urbano era uma promessa contada por irmãos e parentes mais velhos. Sua relação com o mundo era o trabalho na roça, durante a infância, mediada pela relação de propriedade ou de "meia" (relação pela qual o trabalhador usa a terra de um proprietário e tem direito à metade da colheita). Para as mulheres, o trabalho era também na roça ou, em muitos casos, era o serviço doméstico: o cuidado dos irmãos. As famílias eram extensas, às vezes com mais de dez filhos e demandavam muitos cuidados como a preparação dos alimentos e das roupas e o cuidado com a casa. A escola era uma experiência rara no sertão nordestino pois as crianças eram uma mão-de-obra importante na dinâmica familiar. Muitos migrantes entrevistados estudaram pouco, o bastante para aprender a ler e a escrever. Logo em seguida aos estudos contam-se as histórias de migração: o sonho com uma vida mais confortável e com a ascensão social, a possibilidade do novo e da emancipação, sobretudo para as mulheres. A realidade da cidade grande, desde os anos 1930 aos anos 1970, quando a maior parte dos migrantes chegou a São Paulo, era a de uma cidade em franca expansão industrial e urbana. Nos anos 1960 a 1970, quando os entrevistados chegaram a São Paulo, a cidade consolidava-se em torno do crescimento industrial. Muitos dos trabalhadores migrantes chegados entre 1970 e 1980 dedicaram-se à experiência operária, o que não foi o caso dos migrantes que entrevistamos. Estes não acessaram o núcleo operário da cidade, mas, via de regra, o trabalho doméstico (no caso das mulheres) e a construção civil (no caso dos homens). A vida que contam não conta o sentido da vida operária que se esvaziou com a reestruturação produtiva, como muitos trabalhos sociológicos demonstram, mas a vida cujos sentidos eram construídos por mediações diversas, em que pese a mesma mediação presente em todas as suas vidas: o Estado como condutor da política habitacional. Em São Paulo, a maior parte dos

\footnotetext{
${ }^{54}$ Os dados dão conta de que 48,5\% dos moradores de Cidade Tiradentes nasceu em São Paulo, e, entre os migrantes, o tempo de migração é de 22,3 anos, conforme dados do CEM - Centro de Estudos da Metrópole. Georges \& Rizek (2008). Os moradores antigos entrevistados são migrantes e chegaram em São Paulo na década de 1970.
} 
entrevistados instalou-se em bairros da periferia, em favelas ou casas de parentes construídas precariamente em loteamentos periféricos. Chegaram a Cidade Tiradentes pelas mãos do Estado, ao inscreverem-se para o sorteio de unidades habitacionais. Os moradores antigos chegaram ao bairro nos anos 1980 ou início dos anos 1990, e relatam a falta de estrutura do conjunto habitacional.

Em algum momento cada uma das famílias entrevistadas tomou contato com a instituição da Companhia de Habitação de São Paulo - a COHAB-SP, um dos braços municipais da política de habitação brasileira, financiada com recursos do FGTS por intermédio do banco Caixa Econômica Federal. Os estudos na área de habitação mostram como os recursos dos trabalhadores orientaram a política de moradia voltada para as camadas médias e altas da sociedade, deixando descoberta uma grande parcela da demanda, aquela abaixo de 5 salários mínimos. ${ }^{55}$ Esta população inseriu-se na cidade via auto-empreendimento da casa própria, em parte, via ocupações irregulares ou via habitação produzida pelo Estado, como é o caso de Cidade Tiradentes. A produção de habitação pelo Estado em Cidade Tiradentes, no entanto, atende a uma prática de realocação de pessoas expulsas das áreas centrais, seja por processos de desocupação (como o caso da Operação Urbana Faria Lima), seja por processos de gentrificação, que aumentam os aluguéis e o custo de vida.

Além da presença forte do Estado em suas trajetórias há mediações comuns a todos, como o trabalho, as escolas e associações de bairro e as mais diversas igrejas.

Em relação ao trabalho, as transformações vêm sendo amplamente discutidas no âmbito das ciências sociais e dizem respeito à ampliação do desemprego, à introdução de práticas como a terceirização, a transformações na estrutura produtiva que têm como resultados uma constante precarização das formas de emprego ${ }^{\mathbf{5 6}}$.

Em relação às práticas associativas e políticas, as mudanças não foram menos intensas. Na década de 1980, as regiões periféricas de São Paulo estavam embebidas por

\footnotetext{
${ }^{55}$ Maricato (1984).

${ }^{56}$ A bibliografia é extensa. Para uma leitura abrangente, ver Antunes (1999).
} 
sentimentos de identidade ligados à sua experiência como trabalhadores pobres, explorados, cuja ancoragem era urbana, a partir da percepção da espoliação urbana que os migrantes recém chegados à cidade sofriam. ${ }^{57}$ As identidades que se construíam floresciam dentro das igrejas, dentro das chamadas Comunidades Eclesiais de Base, ligadas à Teologia da Libertação (movimento de esquerda dentro da Igreja Católica nos anos 1970 e 1980), e agregavam movimentos de lutas por melhorias no bairro: creches, serviço de abastecimento de água, luz e coleta de lixo, serviço de transportes. A luta construiu as periferias consolidadas (em paralelo à ação da especulação imobiliária) e constituiu a base urbana de um partido que nasceu das aspirações sindicais e urbanas dos trabalhadores brasileiros: o partido dos trabalhadores.

Ao longo das três últimas décadas, o movimento político afastou-se das igrejas e se institucionalizou, com a presença do partido dos trabalhadores nas administrações municipais e posteriormente no próprio governo federal. De experiência de militância combativa e de oposição, a experiência partidária na periferia é hoje um modo e um meio de vida para muitos daqueles que estão envolvidos com a política partidária institucional. Este movimento substitui a força combativa por uma participação mais concorde com as estratégias e práticas institucionais, o que evidencia toda uma gama de relações burocráticas e de micro-poder atuando nas regiões periféricas da cidade.

Ao mesmo tempo, a experiência religiosa deslocou-se do catolicismo para as religiões evangélicas, com viés pentecostal. O católico dos anos 1970 e 1980 estava voltado para a experiência do bairro e para uma prática de solidariedade que procurava também ser crítica em relação aos poderes instituídos. Na experiência dos evangélicos, a solidariedade também está presente e se constitui como uma referência importante na vida do bairro. $\mathrm{O}$ pensamento crítico em relação à realidade, contudo, não se coloca. $\mathrm{O}$ fracasso ou o sucesso social são vistos não de forma coletiva, mas individual, e estão relacionados diretamente a uma instância transcendente, e não à formas de poder que se pode alterar pela mobilização coletiva.

\footnotetext{
${ }^{57}$ O conceito é de Kowarick (1979) e refere-se ao fato de que toda a urbanização das regiões periféricas era realizada pelos próprios moradores, que eram assim espoliados.
} 
As práticas associativas, por outro lado, que estavam também ligadas a possibilidades coletivas, passam a ser orientadas por uma lógica semelhante àquela que gere organizações voltadas para a venda de mercadorias. As práticas associativas, a partir dos anos 2000, são realizadas pelas organizações não governamentais, cuja relação predominante é com os órgãos públicos que liberam seus recursos. Suas práticas, neste sentido, estão o tempo todo orientadas, analisadas e mensuradas pelo poder público, que também está presente, em muitos casos, como uma forma de controle das atividades e saberes ali localizados.

O resultado destes movimentos é o que os analistas vêm chamando de esvaziamento da política, política aqui entendida no sentido forte, como modo de estar no mundo criticamente, de analisar e refletir e re-pensar coletivamente as possibilidades de participação na construção do bairro, da cidade, do país.

\section{Cidade Tiradentes nas últimas gestões municipais}

Os anos do governo Luiza Erundina (1989-1992) tiveram uma coloração distinta na Cidade Tiradentes. Experiências de gestão participativa de espaços públicos, levantamento de um dossiê sobre problemas construtivos, e uma crescente inadimplência marcam o período que foi também de mutirões na zona leste de São Paulo. Muita participação social, efervescência de opiniões e fóruns de criação de espaços coletivos. Caio Boucinhas, arquiteto, ligado à COHAB-SP à época, conta de uma experiência de produção de jardins coletivos na Cidade Tiradentes. A experiência, não entanto, não perdurou após o final da gestão, o que pode revelar o peso que as ocupações cotidianas, os sofrimentos diante das respostas pouco claras do futuro, pode ter na vida dos moradores. Por outro lado, este período foi conhecido pelos moradores como muito difícil do ponto de vista da experiência do bairro em relação às atividades do tráfico de drogas, cujas disputas por territórios provocavam tragédias e homicídios freqüentes nas redondezas. 
Os anos dos prefeitos Paulo Maluf (1993-1996) e Celso Pitta (1997-2000) foram, para os moradores engajados em atividades políticas, anos de luta e resistência. Organizados em movimentos, resistiram à expulsão de moradores de áreas ocupadas, lutaram pela implantação de creches e de linhas de ônibus. No período em que a cidade é gerida de uma maneira conservadora foi que o tráfico em Cidade Tiradentes se organizou, criando um poder paralelo que mantém a ordem (ao menos do ponto de vista das práticas ligadas ao tráfico de drogas) no bairro.

Os anos da gestão Marta Suplicy (2001-2004) foram anos de consolidação de conquistas, como o hospital municipal, a escola técnica municipal e o centro de educação unificado, além de espaços como a sub-prefeitura e a conquista de convênios com entidades sociais na gestão de programas da assistência social e de experiências com orçamento participativo. Se estas conquistas se consolidaram neste período, é porque vinham de uma intensa organização coletiva e de representatividade em meio ao conjunto dos trabalhadores da Cidade Tiradentes. O tráfico, por seu turno, permaneceu como uma organização "paralela" na Cidade Tiradentes, organizando o tempo de muitas pessoas que atuam nestas práticas e atuando muitas vezes, também, na mediação de conflitos.

Os anos Serra-Kassab (2005-2008), por um lado, mantiveram algumas ações da gestão anterior. Foi neste período que o CÉU Água Azul e o Hospital Municipal, concebidos e planejados pela administração anterior, foram inaugurados. Percebe-se uma intensa presença da prefeitura no distrito por meio do que os moradores engajados e mais críticos chamam de "maquiagem". As ruas são limpas, o meio fio é pintado, os varredores estão o tempo todo pela rua. Por outro lado, outras demandas importantes, como a demanda pela ampliação das possibilidades de trabalho, continuam reprimidas ao longo de todas as últimas gestões, que consideram o problema um problema mais abrangente do que as possibilidades de intervenção do poder público municipal. É por isso que alguns analistas têm chamado o atual modelo de gestão pública de gestão da pobreza $^{\mathbf{5 8}}$, em que o poder público lida com os efeitos de políticas econômicas mais amplas, como o desemprego maciço. As políticas de assistência social, por exemplo,

${ }^{58}$ O tema tem sido estudado pelos pesquisadores do CENEDIC - Centro de Estudos Sobre Direitos e Cidadania, e foi abordado por Oliveira e Rizek (2007). 
são mantidas com convênios entre associações (ONGs) e a prefeitura, que mantém critérios para o atendimento e sistemas de indicadores. Do ponto de vista da política para a infância e juventude, por exemplo, em Cidade Tiradentes há ONGs que realizam atividades complementares à escola e acompanhamento de jovens em liberdade assistida. O fôlego para o acompanhamento à família e a integração de políticas, como a política de geração de emprego e renda, é, por outro lado, restrito. Outro exemplo é a expansão da política de agentes comunitários de saúde no bairro que não consegue, no entanto, obter resultados efetivos do ponto de vista da redução dos índices de gravidez precoce indesejada, para citar apenas um exemplo, que não é dos mais trágicos (os técnicos da área da saúde estão preocupados com a ineficiência deste atendimento em relação ao crescimento da tuberculose no bairro, para citar outro exemplo um pouco mais difícil). Do ponto de vista da educação, o grande desafio dos primeiros anos da Cidade Tiradentes era universalizar o atendimento. Ao menos o ensino fundamental têm conseguido estes índices. A evasão em relação ao ensino médio, contudo, permanece. A escassez de políticas para esta faixa etária é agravada pela presença do tráfico de drogas como alternativa de ganhos rápidos, status social entre os jovens e presença constante de atividades que envolvem adrenalina, que usualmente atraem os jovens.

A gestão destas políticas é recheada de técnicas de eficiência e indicadores sociais, mas, efetivamente, talvez as soluções necessárias devessem partir de outras vias de reflexão e atuação. Esta crítica está presente no campo acadêmico com freqüência, na análise do esvaziamento do campo da política:

"É no vazio da política que a violência e a gestão das populações se instalam e produzem a ausência do mundo partilhado como referência de estar no mundo: substituem os espaços públicos por estratégias de autolegitimação, ao nos convencer de que, diante de nossa urgência, o conhecimento especializado de técnicas e fórmulas de intervenção está aí para resolver os problemas com eficácia e nos proteger do incerto. O que eles configuram, no entanto, é um modo de gestão da vida coletiva que faz repetir, mais uma vez, o bloqueio dos caminhos que podem revitalizar o impulso das idéias e ações democráticas, ou seja, a política.” Paoli, (2007, p. 226)

Aparentemente, a atuação das administrações municipais que intervêm no cotidiano de carências e inseguranças da população pobre por meio de programas e 
projetos, é impotente diante da lógica das políticas macro-econômicas que são responsáveis pela manutenção das desigualdades. Um campo alternativo de atuação deveria supor a capacidade da população, que é entendida como "clientela", promover os seus direitos de cidadania por meio da participação efetiva nas políticas e na possibilidade de repensar até mesmo as políticas federativas.

A participação na Cidade Tiradentes é grande. Há mais de trezentas organizações não governamentais e associativas na região ${ }^{\mathbf{5 9}}$. Contudo, sua atuação não dá conta de produzir alternativas de gestão dos recursos públicos, mas ao contrário, está atrelada aos recursos já orientados. São associações conveniadas ou contratadas pela prefeitura, cujas intervenções são projetos e programas baseados na técnica de gestão social, segundo a qual o conflito deve ser apaziguado, e as respostas às questões deixam o campo aberto da invenção política para se tornarem técnicas que acabam por substituir a ação e a reflexão políticas. Paoli (2007). É por isso que uma das leituras possíveis da relação entre Estado e cidadãos na atualidade situa-se no campo da assistência, e não do reconhecimento de direitos.

\section{Breves considerações sobre o fenômeno da violência em Cidade Tiradentes}

Além da violência simbólica que o cidadão sofre nesta lógica de gestão dos serviços públicos, não raro tendo que passar por episódios em que servidores públicos usam de seu micro-poder para humilhá-los publicamente e obscurecer seus direitos, os cidadãos do bairro confrontam-se com uma sombra provocada por agentes conhecidos como traficantes.

A história do tráfico em Cidade Tiradentes remonta às origens do bairro. Nos primeiros anos de urbanização, a violência em realidade estava associada aos freqüentes assaltos aos próprios moradores. Assaltos na rua (em que se levava o dinheiro da condução e, às vezes, o dinheiro do pagamento) invasões de casas, roubo de roupas no

\footnotetext{
${ }^{59}$ Segundo pesquisa Ferreira (2009).
} 
varal, eletrodomésticos dentro das casas. A partir dos anos 1990 as queixas passam a se referir a inúmeros homicídios praticados em torno da disputa por "bocas de fumo" (pontos de vendas de drogas). O bairro fica conhecido como um dos mais violentos da cidade, e é estigmatizado. Esta situação durou anos e alguns moradores interpretam que foi parte do processo de construção da organização PCC - Primeiro Comando da Capital, uma extensa rede de traficantes e assaltantes de bancos que passou a organizar as atividades criminosas na cidade. A partir dos anos 2000, o PCC torna-se hegemônico na Cidade Tiradentes, e os homicídios cessam. A organização institui um rigoroso código de conduta que proíbe, por exemplo, o assalto a moradores da Cidade Tiradentes. As "bocas de fumo" são gerenciadas por integrantes da organização e estão submetidas a uma mesma liderança. Com a conquista de território, os embates entre traficantes cessaram. Os moradores avaliam este processo como um ganho para a vida do bairro, pois trouxe a todos a sensação de segurança e paz (que está relacionada a uma autoridade claramente reconhecida). Esta autoridade, no entanto, está contrária as leis do município e do país, o que não significa que não seja legitimada localmente e mesmo que mantenha relações com as autoridades policiais para manter o seu domínio, baseadas na destinação de recursos a parte da polícia.

O tráfico está na cotidianeidade dos moradores. No setor $\mathrm{G}$, por exemplo, (ocupação originada pela criação de um alojamento para moradores expulsos pela Operação Faria Lima), moradores avaliam que ao menos $50 \%$ de quem vive ali está, de alguma forma, envolvido com o tráfico, seja participando ativamente nas funções, seja oferecendo esconderijos para as armas em suas casas. Mesmo distante do setor G, nos edifícios, muitos moradores compram produtos roubados por preços menores aos praticados nas lojas.

Aqueles que ascendem no tráfico passam a ter poder reconhecido pelos moradores e são muitas vezes chamados como mediadores em situações conflituosas em momentos em que se entende que a polícia não seria tão eficiente. Foi o caso de uma briga relatada no edifício em que se realizou a pesquisa, iniciada por uma divergência em relação ao volume do aparelho de som, que evoluiu para um enfrentamento com faca. O "general" do PCC foi chamado para apaziguar os ânimos e dar um encaminhamento à situação, que não teve maiores conseqüências. 
Nem todos os moradores acorrem aos membros do poder paralelo. O discurso mais comum revela um desejo de distanciamento, acompanhado de um respeito à autoridade legítima "eu cá e eles lá". Mesmo nestes casos, todos os integrantes do "movimento" são conhecidos e reconhecidos. Não há como ficar alheado ao que ocorre à volta.

Como pesquisadora, a autora não chegou a conhecer ou identificar nenhuma pessoa associada diretamente a atividades criminosas, ao tráfico ou ao PCC. Numa ocasião em campo, entretanto fui informada de que o "comandante" do PCC sabia de minha presença e das atividades que eu realizava no bairro. Em nenhum momento, no entanto, cheguei a ser inquirida ou questionada acerca de minha presença por ali e de minha pesquisa. Quando muito um morador que trabalha num órgão policial esquivouse por inúmeras vezes de minha presença, negando-se a ser entrevistado, sem dar muitas justificativas.

A violência é um assunto que perpassa o tecido urbano e está presente na Cidade Tiradentes, no discurso e na prática. Ela surgiu em quase todas as conversas em campo. $\mathrm{Na}$ conversa com a primeira síndica entrevistada em Cidade Tiradentes foi o tema central. As atividades ligadas ao tráfico são um tema presente, mas não muito esclarecido, seja porque ele é realmente desconhecido pelos moradores, que mantém-se à distância, seja por cautela e precaução. O tráfico permanece numa zona de sombra ${ }^{60}$, algo com o que os moradores têm de lidar, mesmo sem querer. Às vezes ao interpelados diretamente pelos problemas causados pelo tráfico, como no caso da primeira síndica entrevistada, que relata casos de ocupação de apartamentos vazios no edifício em que atuava e morava, às vezes são instados a evitar locais e momentos no bairro para evitar os traficantes.

O tráfico e o crime organizado são uma constante a partir da década de 1990 não apenas em Cidade Tiradentes, mas em todas as periferias paulistanas e cariocas, pelo menos $^{61}$. O tráfico está imbricado no cotidiano dos moradores não por estar espacialmente próximo, mas por estar próximo em termos dos vínculos, já que a grande

${ }^{60}$ A expressão, bastante usada por Telles (2007), é de Agamben (2007).

${ }^{61}$ Para uma leitura do fenômeno da violência nas periferias paulistanas ver Telles (2007). 
parte dos membros do crime organizado são pessoas do bairro, que cresceram e foram criados nos bairros. Todos os jovens entrevistados têm amigos, companheiros de escola fundamental, ligados ao "movimento". Todos os pais ou mães conhecem alguma história trágica envolvendo filhos de conhecidos. O grande desafio, para os pais, é criar os filhos ao largo dos riscos da atividade criminosa. Mas, objetivamente, os laços que os jovens têm entre si e suas escolhas muitas vezes escapam às possibilidades de atuação dos pais. Esta senda, embora não tenha sido objeto da pesquisa, é um aspecto relacionado à forma como as práticas urbanas se concretizam, às dinâmicas de acesso aos espaços e de interdições espaciais, e às representações que se faz do outro.

Não é apenas dentro do crime organizado, no entanto, que a violência ganha visibilidade e acontece. Assassinatos em brigas são também presentes nos relatos dos moradores e evidenciam um aspecto de banalização da vida que perpassa o tecido social, não apenas na Cidade Tiradentes, mas em todas as grandes cidades do país. Em Cidade Tiradentes, durante a pesquisa de campo, houve um episódio de violência envolvendo um homicídio. O relato a seguir é trecho do diário de campo produzido na ocasião:

No dia seguinte à madrugada do crime o ambiente estava um pouco mais tenso e silencioso do que nos domingos anteriores e os moradores expressavam ares de preocupação e discursos de distanciamento em relação ao que ocorrera. O consenso geral era de que o homem de alguma forma procurara "encrenca". O código moral presente nos discursos dava conta de justificá-lo de alguma maneira pelo comportamento do assassinado, que cometera adultério.

O assassinato ocorrera ao lado do edifício da pesquisa, e a vítima era conhecida dos moradores. O clima era de incômodo, e a necessidade de elaboração passava por uma maneira de compreender o ocorrido, atribuindo significados que fazem sentido à vivência compartilhada, o casamento e seus valores. Colocado dentro deste contexto, o ocorrido passou, deixou de fazer parte das conversas comigo, ao menos. Em seu lugar, 
voltaram as conversas sobre os problemas associados ao condomínio, as críticas à síndica, as conquistas ou desilusões profissionais, as preocupações com os filhos. A violência é tolerada porque as formas de dirimi-la escapam às possibilidades cotidianas. Esquivando-se dela pelo distanciamento ou tendo uma relação transcendente com as práticas religiosas, as ocupações primordiais são as interpelações do cotidiano, e nelas o trabalho é irremediavelmente o ponto mais forte, mesmo na vida de quem está distante da formalização e não aparece nas estatísticas.

\section{A experiência do condomínio na Cidade Tiradentes: a visão da síndica}

O espaço coletivo é um lugar de passagem. Ao mesmo tempo, é um lugar de parada. É um lugar de troca e de elaboração do cotidiano. Ali não se ganha a vida, como no ambiente de trabalho. Ali, tampouco, se descansa (como em casa), ou se entende que se têm obrigações (como no trabalho e em casa). Ali não se transcende (como na igreja) e não se brinca (a não ser as crianças, sempre criando formas de tornar lúdicos os mais insípidos ambientes).
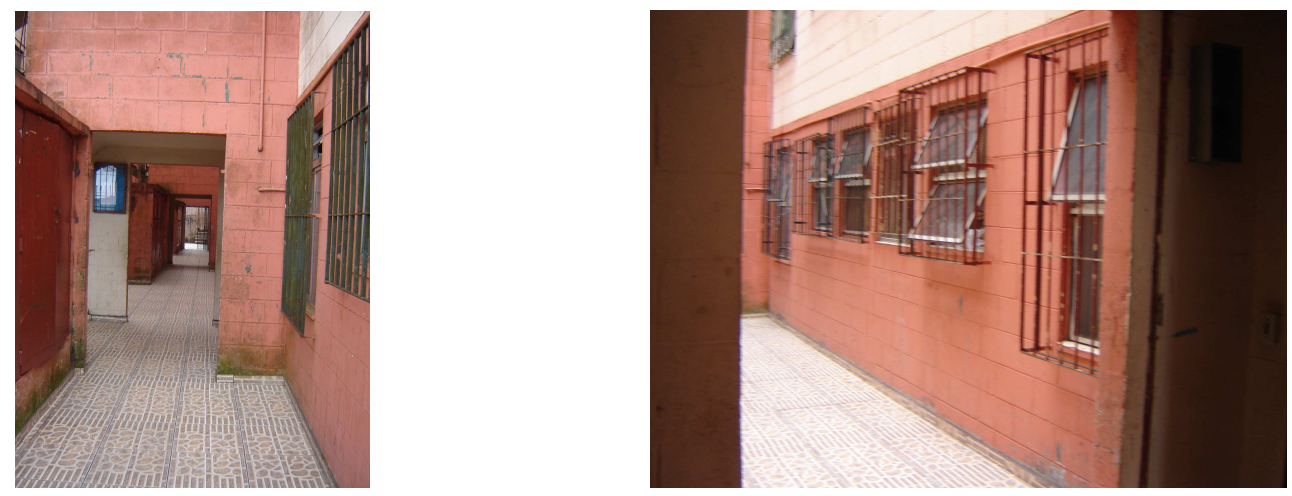


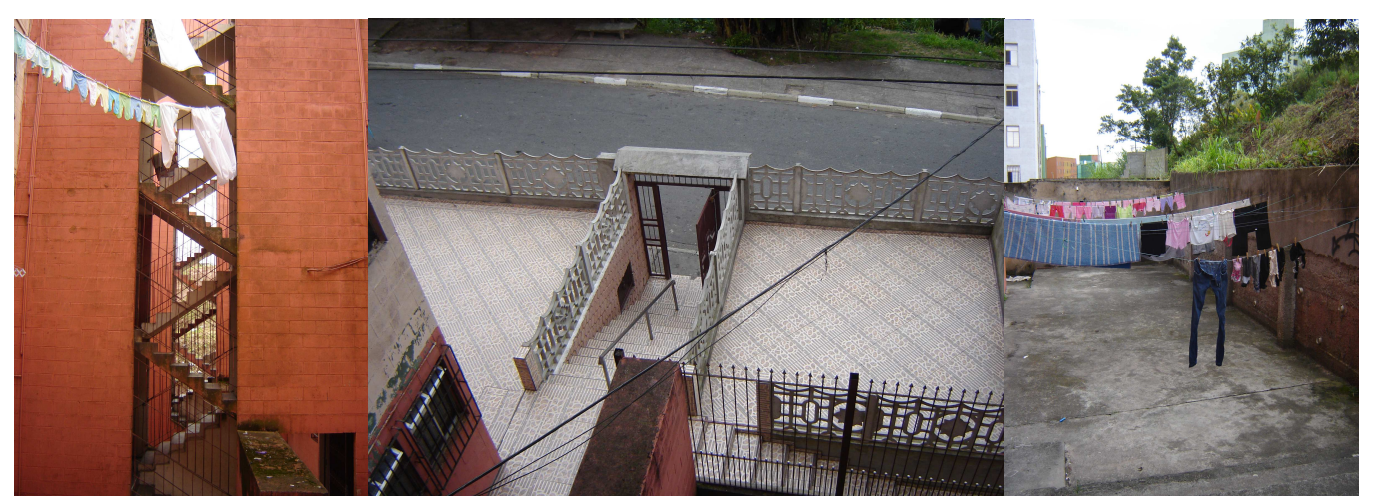

O espaço coletivo é o lugar do outro, daquele que se respeita, ou que se despreza, mas cujo direito de estar ali (em geral) é respeitado. É o lugar da solidariedade, é o lugar em que se constrói o discurso de proximidade ou de distanciamento. É o lugar em que se constrói (ou não) a noção da coletividade. É um lugar em que providências são demandadas, e este é o ponto central do espaço coletivo. Alguém precisa limpar o espaço coletivo, alguém precisa dividir a conta da água, alguém precisa cotar os preços para uma reforma. Este alguém é alguém que represente a todos, que aparentemente neutralize as diferenças entre todos os moradores, mas que, sobretudo, aja em prol do espaço coletivo. Este alguém é o síndico. Ou, no caso estudado, a síndica.

Figura presente em estruturas condominiais em edifícios de luxo, em edifícios de classe média e em conjuntos populares, o síndico é alguém a quem se recorre para a resolução de problemas de toda a ordem: problemas de infra-estrutura, tensões de relacionamento. A ele são ditos os incômodos da vida em condomínio e os aspectos que se materializam nas tensões das relações de vizinhança. Em alguns espaços, ele é também a figura que agrega, que organiza algum evento comemorativo. No caso estudado em Cidade Tiradentes, não há espaço para festa, mas para a mercantilização das relações: quanto se paga pelo condomínio, pela taxa de obra, pela água, o que revela aquilo que se tem em comum, a equivalência da situação de trabalho, a preocupação constante com o ganha-pão. 
Alguns condomínios em Cidade Tiradentes entendem que o síndico dedica-se a atividades pelo bem de todos e que sua função tem o direito de ser remunerada. Outros condomínios não são orientados por este reconhecimento. Nestes, o síndico (ou a síndica), é quase um missionário.

Este é o caso de Adriana, a primeira síndica entrevistada na Cidade Tiradentes. Adriana é uma mulher de meia-idade, às voltas com suas responsabilidades familiares e a criação de dois filhos (é casada, mas afirma não poder contar com o apoio do marido, "enrolado" em questões de trabalho e sobrevivência). Adriana nasceu em Santos, mas passou sua infância em Sergipe, com a mãe e a avó. Seu pai trabalhava em Santos e ia esporadicamente para Sergipe. Adriana veio a São Paulo com 16 anos para trabalhar e estudar. Em Sergipe ela estudava, mas quando seu pai ficou doente ela precisou sair da escola. A possibilidade de estudar, para ela, estava associada a São Paulo, em que a possibilidade de conciliar trabalho e estudos parecia-lhe mais promissora.

Em São Paulo ela trabalhou como empregada doméstica e como caixa de supermercado, vivendo em casa de parentes, até conhecer seu marido. Casada, foi morar na casa da sogra e trabalhar com vendas de Yakult. ${ }^{62}$ Quando foi chamada para ocupar seu apartamento na COHAB-SP (ela estava inscrita desde alguns anos antes), ela trabalhava em Interlagos. Fez a opção de manter-se no trabalho por seis meses, convivendo com um deslocamento cotidiano entre Interlagos e Cidade Tiradentes.

"Eu to falando que, quando eu vim né, aí nisso, é, realmente eu achei muito distante e aí eu fiquei passando praticamente mal assim. Eu fiquei assim adoentada, porque às vezes quando alagava lá a avenida Interlagos, né, enchia d'água e eu não conseguia atravessar, às vezes eu só chegava aqui, tomava banho e voltava. Eu chegava praticamente 3 horas, 4 horas da manhã, tinha um ônibus que trazia a turma já de manhã, né, e tomava banho e

\footnotetext{
${ }^{62}$ A comercialização de Yakult, uma espécie de bebida derivada do leite, acontece por meio de uma rede de vendedoras de rua ligadas a coordenações regionais nos bairros. . O trabalho de porta em porta que configura a extensão de vendas de empresas como Yakult e Avon, é bastante comum entre a população de baixa renda. Configura um trabalho sem vínculo empregatício, em que a remuneração é realizada por comissão pelas vendas. As trabalhadoras (geralmente são mulheres), devem organizar seu próprio trabalho. Em ambos os casos há uma coordenação que é necessária ser seguida, formada por vendedoras mais experientes.
} 
voltava novamente trabalhar, isso aí pra mim foi assim dava muito cansaço. Ah, mas eu falei, vou guentar porque eu tinha que assinar, eu tinha que trabalhar pra poder assinar o contrato daqui. Por seis meses eu tinha que ter holerite, tinha que ter tudo direitinho, né, aí eu guentei os 6 meses."

No discurso de Adriana, como no de outras mulheres trabalhadoras, o drama de passar os dias trabalhando é a perda de contato com os filhos. No seu relato, ela põe a questão da seguinte forma: manter o contato com os filhos ou manter um padrão de consumo acima da média da vizinhança para eles, como compensação. Esta segunda alternativa implicaria em maiores conseqüências para eles, ela avaliou, e parou de trabalhar na zona sul, buscando atividades que fossem mais flexíveis do ponto de vista do horário de trabalho.

"Acabei saindo [do trabalho], mas saí mais por causa dos meus filhos mesmo, aí eu tracei um objetivo na minha vida que eu só ia, tá, voltá a trabalhar quando meus filhos tivesse grande e que tivesse com uma cabeça boa e que tivesse segurança que não era mais perigoso pra ele, por causa do local onde eu trab..., onde eu moro, né, eu não conhecia ninguém, então esse objetivo eu tracei na minha vida, eu falei eu vou, só vou voltar a trabalhar agora quando meus filhos crescer, trabalhar o quê resistrado, é lógico que eu vou procurar um meio de sobrevivência sem ser assim o dia todo pra poder ficar perto deles. Aí que é que eu fiz, fui vender lingerie, fui vender hot dog, mini-pizza, mas assim, eu, eles estudavam de manhã, né, eu ia trabalhar de manhã. Eles voltavam à tarde, eu voltava também. Mesmo algumas horas...Eu saía pra alguma coisa,sempre estava de olho neles, mas foi um objetivo que eu tracei na minha vida mesmo.Aí quando meus, agora meu filho ficou com 17 anos, eu voltei, 17, ele tá com 18, então faz 3 anos que voltei [a trabalhar]." 
Adriana tornou-se agente comunitária de saúde, atividade ligada à Prefeitura Municipal de São Paulo, em 2003. Esta sua alternativa de trabalhar no bairro pode ser compreendida a partir do desdobramento de sua atividade como síndica, que ela começou a desenvolver logo ao parar de trabalhar na zona sul. Como síndica e como moradora local, Adriana passou a se envolver com as questões do bairro.

Ela começou a se envolver com as questões do edifício quando ficou em casa trabalhando, como "viradora" (vendendo salgados). Por outro lado, sua experiência no mundo do trabalho foi importante para dar a ela uma visão de racionalidade econômica que ela usou na gestão do edifício. Seu envolvimento nas questões condominiais surgiu quando uma conta de água do prédio estava atrasada e ela chamou os moradores para conversar. O consenso dos moradores foi identificá-la como alguém que tomaria conta das questões coletivas.

O espaço coletivo pode ser o lugar de organização da vida coletiva, ou pode ser simplesmente o lugar de encontro em que estas questões coletivas não são organizadas de forma clara. Quando um processo de organização se inicia, são chamadas reuniões e assembléias, atividades que mobilizam parte dos moradores.

No relato de Adriana, bem como na visão comum sobre as questões condominiais no edifício pesquisado em Cidade Tiradentes, os moradores omitem-se das questões coletivas. Esta omissão parte do entendimento de que, de alguma forma, alguém é mais responsável, ou está mais preparado, para cuidar do que concerne a todos. Ou então, do entendimento de que aquilo tudo não é tão importante quanto as questões privadas ou públicas com as quais se têm de lidar cotidianamente. De um ou de outro jeito, nos dois casos em que a atuação das síndicas foi relatada, houve um momento de tomada para si de uma responsabilidade entendida como coletiva.

A primeira providência tomada pelo coletivo, nos dois casos, é coletar o dinheiro e pagar as contas, negociar os atrasados e organizar a emissão de boletos, a conta que cabe a cada um. No caso de Adriana, este processo envolveu a legalização da situação jurídica do condomínio, pois, quando ela assumiu, o condomínio não era pessoa jurídica. Ela usava sua própria conta corrente para movimentar as contas do prédio. Por outro lado, Adriana tinha medo de ser assaltada ao receber o dinheiro dos moradores 
para pagar as contas do edifício. Ela mobilizou os conhecimentos adquiridos durante o período de trabalho com Yakult e implementou uma prática de pagamento via boleto bancário, o que ressalta a importância da experiência no mundo público para a organização coletiva. A experiência do trabalho possibilita uma rede social e de práticas que promovem a qualificação dos trabalhadores, quando eles apropriam-se de práticas administrativas ou de gestão, por exemplo.

"pra abrir essa,conta foi difícil porque, na época, era 15 reais,o condomínio,e banco nenhum aceita. (...)Muito baixo,num aceitava.E eu tinha tesoureira que ela falou assim ,ah,eu tenho conta no Bradesco lá na Rebouças,aí eu comecei a andar em tudo quanto é banco,ninguém aceitava,mas é assim eu abro uma poupança,falei poupança eu não quero por débito automático da água e da luz e movimentar a conta com cheque.Aí não,só se for poupança,e andando.Quando eu cheguei lá na,nessa agência lá que ,a Nádia,chamava Nádia, a tesoureira me apresentou pro gerente,ele era novinho, um rapaz bem novinho,ai eu até hoje eu rio,eu dei uma de doida lá,acho que eu já tava tão nervosa,sabe,de tanto levar não do gerente,quando eu cheguei lá ele falou assim,olha não tenho condições, quem vai me garantir que essas pessoas vão depositar o dinheiro numa conta pra senhora tá pondo débito automático da água e luz,quem vai me garantir?É muito baixo esse valor.Aí,eu falei assim,eu garanto pra você e eu vou dar um jeito.Ele falou,não tenho condições, ai eu falei assim,"o senhor sabia que eu to passando perigo de vida?",foi automático,sabe, aquele desespero,o senhor sabia quantos bandidos têm lá onde eu moro?" Cê sabia que eles podem ir lá na minha casa,eu tenho 2 filhos e eu mesmo morrer,porque ele mesmo vão pagar condomínio pra mim,depois eles mesmo podem ir buscar.Eu só quero uma conta pra guardar esse dinheiro pra não ficar na minha mão,pra eu,_,pra eu livrar minha vida,pra pagar as contas pra eu não ficar movimentando.O senhor teve idéia de eu sair lá de Tiradentes,cê tem idéia onde é Tiradentes?Não senhora.Então,já pensou eu saindo com dinheiro de lá pra pagar a conta.Pois ai,eu,sei lá,sabe quando sai?Eu olhei pra ele assim e ainda ri,e se acontecer alguma coisa comigo o senhor vai ser um dos responsáveis porque o senhor tá negando de abrir uma conta pra mim pra eu guardar um dinheiro porque eu acho que eu sou uma cidadã e tenho direito.E ele assim,eu acho que eu falei de uma maneira assim que,ele olhou assim pra mim,eu lembro como se fosse hoje,ele pegou os 
papéis e bateu assim em cima da mesa né,começou a rir. (...). .A que que eu fazia,como na Yakult eu recebia tudo com depósito, eu não mexia com dinheiro,foi isso que eu expliquei pra ele,eu num,na Yakult não se lida com dinheiro,se lida com deposito,né,você vem pagar sua conta com depósito. Então eu implantei no prédio.Vinha todo mundo pagar pra mim na minha porta,mas com um comprovante de banco,não com dinheiro."

Na ocasião da entrevista, Adriana não recebia salário pela função de síndica, embora fosse isenta da taxa de condomínio. A equipe era composta por Adriana, um secretário e um subsíndico. A atividade de gestão condominial foi relatada por Adriana como desgastante. Sua atuação, entretanto, passa a ganhar um espaço que acomoda as relações no espaço coletivo. É por isso que o afastamento é tão difícil. Adriana tentou afastar-se, mas sentiu-se compelida a manter a posição pois ninguém assumiu em seu lugar. Ela voltou a se ocupar das contas do prédio. Neste retorno, fez um levantamento dos pagamentos das taxas condominiais nos anos em que esteve fora e encontrou um déficit de $\mathrm{R} \$ 22.000,00$. Trata-se de um dinheiro que poderia ter sido aplicado em benfeitorias do prédio, mas não foi efetivamente.

Períodos longos sem acompanhamento não significam ausência de acontecimentos, mas, por vezes, podem significar a atenção voltada para outros eventos. As famílias ficam às voltas com suas questões próprias e muitas vezes a gestão do espaço coletivo não é entendida como prioritária se não houver uma figura claramente responsável pelas atividades de cobrança e prestação de contas.

A conta de água no prédio de Adriana foi individualizada, ou seja, cada família paga sua própria conta e a punição para o não pagamento é o corte do abastecimento da família. As contas de luz e água coletivas aos espaços comuns são pagas junto à taxa de faxina, na taxa de condomínio. Adriana instituiu um fundo para cobrir eventuais descompassos ou imprevistos, com recursos do próprio condomínio. É uma ação tomada individualmente como prevenção de futuros problemas além de ser em parte, do conhecimento de planejamento e gestão que se adquire durante a experiência profissional. 
A opção pela conta de água individualizada foi tomada após longos e difíceis processos de cortes no abastecimento. A manutenção do pagamento individual de uma conta coletiva não garante a continuidade do abastecimento, pois, se todos não pagarem, não há dinheiro em caixa para efetuar o pagamento da conta. O corte é inevitável. Moradores dos embriões identificam este como o maior problema condominial: contas coletivas. Com a individualização das contas e a instalação de um relógio em cada apartamento, cada família responsabiliza-se pela continuidade do próprio abastecimento.

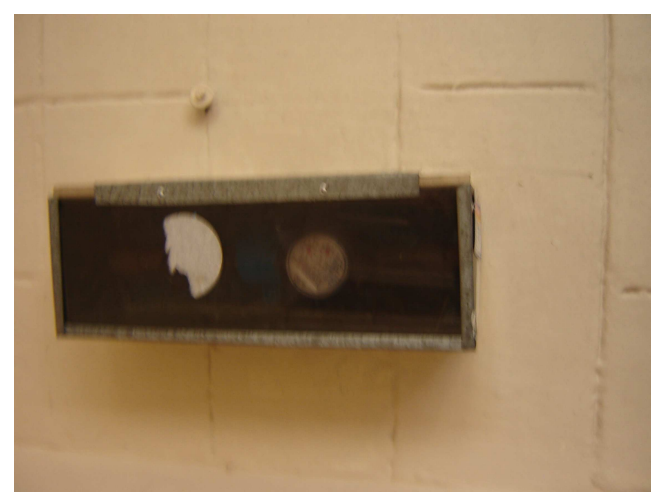

Relógio de água na entrada de apartamento.

Moradores antigos, como Adriana, conhecem todos no prédio. Sabem da situação familiar (quem está desempregado, quem está trabalhando, quem está casado e quem está separado, quem é ligado ao tráfico ou não) e sabem dos contratos de gaveta. Sabem quem deixa o prédio para uma situação melhor ou quem deixa o prédio para morar numa favela, por exemplo. Em sua posição de síndica, ela conhece todos os apartamentos e sua situação, se são alugados ou comprados, e quem tem contrato direto com a COHAB-SP. Não são informações que ela passe à COHAB-SP, por exemplo. Ela é uma moradora como outra qualquer, e sua relação com a COHAB-SP é praticamente a mesma de todos os outros moradores, à exceção de que ela pode ter um contato direto para situações emergenciais, como foi o caso da ocupação de apartamentos vazios por pessoas ligadas ao tráfico no seu prédio. 
Nestes casos, o que se depreende é que a COHAB-SP não mantém procedimentos padronizados, mas atua caso a caso. Esta atuação é resultado das mudanças de critério e de políticas quando das mudanças de gestão. Por exemplo, durante as gestões Maluf e Pitta, houve recorrentes ações de reintegração de posse de apartamentos inadimplentes. Estes apartamentos, no entanto, não foram prontamente ocupados por novos mutuários, o que os manteve vazios. Foi neste ínterim que foram ocupados pelos traficantes, que arrombaram a porta e passaram a usá-los como espaços de "boca de fumo" ou simplesmente como local de estar, como meio de fazer dinheiro pela venda de janelas, vasos sanitários.

Foi o maior desafio de Adriana como síndica. Um dos traficantes era conhecido de Adriana desde menino. Ela precisava tirá-los do prédio para manter a sensação de segurança em relação aos demais moradores, que a pressionavam, mas sentia-se ameaçada pela situação. Afinal ela procurou a COHAB-SP, que expulsou os traficantes com o apoio da polícia.

Este episódio ilustra a atuação da COHAB-SP. Se, por um lado, ela foi responsável pela produção de um bairro inteiro, por outro lado, ela manteve-se distante em muitos aspectos. Como já foi relatado, houve experiências de fomento às ações coletivas, como na gestão Erundina. Em outros anos, ela esteve presente apenas com o posto de apoio, que simplesmente encaminhava os moradores com dúvidas em relação aos contratos e financiamentos à sede da COHAB-SP, no centro de São Paulo, em que seus casos eram analisados individualmente, a partir de critérios variáveis em função de quem fosse a administração. Em outros anos, ela atuou incisivamente buscando reintegrações de posse, como já foi citado. Em outros anos, ela concedeu anistias a parte dos mutuários (como na gestão Marta Suplicy). A COHAB-SP não mantém registros dos moradores originais, nem banco de dados da situação sócio-econômica. Sua atuação no momento atual é na definição de critérios de cobrança para as prestações. Por outro lado, não se espera que o valor das obras do empreendimento seja quitado por meio dos mutuários. A dívida da COHAB-SP com a Caixa Econômica Federal, que financiou a obra, já foi paga. Os acertos agora são entre mutuários e COHAB-SP ${ }^{63}$.

\footnotetext{
${ }^{63}$ Informação obtida junto à funcionária da COHAB-SP.
} 
Durante a pesquisa, a atuação da COHAB-SP foi pouco evidente. Aparentemente, reina a informalidade ao largo das regras do financiamento dos conjuntos: comércio em local que não poderia existir, na informalidade, negociações de apartamentos e garagens que não poderiam existir. No caso das negociações dos apartamentos usualmente procura-se o órgão para obter o aval. "Basta fazer um contrato em cartório que ele será reconhecido", dizem os moradores. E geralmente o novo mutuário passa a receber seu carnê, se fizer o movimento de procurar a COHAB-SP. Ao procurar o posto de atendimento para saber de regras de financiamento obtive a resposta de que as regras ainda não haviam sido definidas.

Embora seja pouco evidente no cotidiano, a COHAB-SP é como uma sombra para muitos moradores, pois a mudança dos critérios de financiamento e a atuação para a reintegração de posse, por exemplo, das garagens (com a supressão dos espaços comerciais), pode vir a acontecer em qualquer momento.

De toda forma, a atuação na gestão Maluf-Pitta ( ) evidencia a pouca compreensão da dinâmica do bairro e das conseqüências da atuação no espaço. Esta atuação pode ser entendida como um movimento de legitimação da máquina-estatal diante da opinião pública, mas que não é solução para as contradições vivenciadas na periferia e suprime a política ao agir com violência institucional ${ }^{64}$. (Paoli, 2007).

Empreender um conjunto habitacional poderia ser sinônimo de compartilhar a gestão e integrar políticas públicas, a partir do entendimento de que a moradia é apenas um dos aspectos dos direitos sociais dos cidadãos. A política habitacional, ao contrário, é vista e tratada como uma política entre outras, em que as práticas não são mantidas e registradas, e os critérios de atuação são indefinidos.

\footnotetext{
64 "Quando há esse tipo de exibição das virtudes governamentais no mar da necessidade extrema, como no caso das inúmeras tragédias violentas na paisagem das cidades brasileiras, o próprio caráter préinterpretado do acontecimento como um 'sintoma' engendra fantasmas que aprofundam preconceitos e medos, mas sobretudo a própria indistinção entre o falso e o verdadeiro na vida social e política." PAOLI (2007, p. 227).
} 
No rés-do-chão da realidade cotidiana o mediador (no caso, a síndica) situa-se entre a sua posição de identidade com os moradores e entre a posição de violência institucional da máquina pública, posição que a coloca em risco.

No depoimento de Adriana, ela deixa entrever ainda o acirramento da contradição de sua posição. Um ex-morador do prédio saiu da cadeia e procurou-a em busca de um lugar para morar. Ele crescera no prédio e retornava após 8 anos na cadeia. Adriana ofereceu-lhe o apartamento vazio, mas a COHAB-SP apareceu para expulsá-lo. Adriana estava na posição de uma liderança que institui acordos locais, mas eles não são legítimos do ponto de vista da COHAB-SP. Se a COHAB-SP se manteve ausente em muitos momentos, ela surgiu para deixar Adriana numa posição de risco, pois aparentemente ela seria a pessoa com o contato com a COHAB-SP que teria chamado a entidade para expulsar o morador. Adriana conseguiu convencer o rapaz de que não tinha sido ela a chamar a COHAB-SP. O jovem e seus amigos passaram, então, a ameaçar o funcionário da COHAB-SP. Agora Adriana era protegida pelo tráfico e ameaçada pela COHAB-SP.

No caso anterior, ela aliara-se à COHAB-SP para expulsar os traficantes. As negociações são, portanto, circunstanciais. A compreensão do lícito e o ilícito não podem ser essencializados. As fronteiras são tênues e móveis.

O segundo episódio que Adriana conta terminou de forma trágica, com o suicídio do rapaz e o incêndio do apartamento, provocado pelos traficantes. A situação apenas pôde ser amenizada com a prisão dos traficantes, quando Adriana pôde reformar o local, junto com uma pessoa interessada em morar no apartamento, com o fundo de obras do prédio.

Adriana, eleita síndica, colocou-se numa posição entre a conivência e a repressão, a depender do momento e das forças que ela tinha a seu lado ou ao lado dos traficantes. Quando teve a $\mathrm{COHAB}$ ao seu lado, ela entrou em um apartamento abandonado invadido pelos traficantes. Quando estava sozinha, enfrentou pessoalmente o traficante, mas sem pedir apoio da polícia. A denúncia significa represália imediata, e, por isso, todos temem denunciar quem se envolve com o tráfico ou com o crime organizado. A postura de Adriana mobiliza afetos, posturas que oscilam entre a rigidez 
e a flexibilidade e fazem com que o seu próprio projeto de vida oriente-se nesta fímbria entre o legal e o ilegal. Como os estudos recentes têm demonstrado, mais do que uma clara oposição entre legalidade e ilegalidade o que se vive em cidades como São Paulo tanto do ponto de vista da regulação urbana e fundiária - quanto do ponto de vista do trabalho é um emaranhamento entre o lícito e o ilícito, o legal e o ilegal. ${ }^{65}$

Esta convivência entre ilegalidade e legalidade transpassa todas as questões da vida em Cidade Tiradentes. A começar pela ação do próprio estado, produtor de irregularidade ao construir num local sem a regularização fundiária. ${ }^{66}$ No que tange à relação com a COHAB-SP, ela é evidenciada pelos altos índices de inadimplência, geralmente sem conseqüências, e pela trangressão da norma de uso dos apartamentos como espaços estritamente residenciais.

Beneficiários de política de habitação, a inadimplência junto à COHAB-SP chega a 60\%, de acordo com dados Associação Brasileira de COHAB`s. O uso do prédio para atividades comerciais não é permitido por lei, mas amplamente usual. Mesmo porque a ausência desta ação significaria ausência do comércio mínimo dentro do distrito, uma vez que todas as terras são da COHAB-SP e há problemas de regularização fundiária em todo o distrito. Com o tráfico e com o crime organizado não poderia ser diferente. Em determinadas situações da vida um indivíduo pode ser conivente com o tráfico, ou por medo da represália ou por se beneficiar de alguma vantagem, como proteção ou vantagens pecuniárias. $\mathrm{O}$ entendimento da legalidade ou o entendimento do que é lícito advém da força das circunstâncias, do temor ou da proteção que se tenha em relação ao grupo que "comanda" o tráfico na região.

\footnotetext{
${ }^{65}$ Como em Telles (2006).

${ }^{66}$ Silva (2004).
} 


\section{Um percurso etnográfico}

O olhar etnográfico desta dissertação fotografa momentos de muitas indas e vindas zona leste adentro, e, ao escrever, percebo as transformações na percepção do espaço construído, as leituras espaciais, o crescente tomar contato e aproximar-se de uma realidade que era tão nova há alguns anos e que passa a fazer parte da cartografia da cidade de que hoje disponho.

A extensão do bairro parecia menos explorável do que os bairros pequenos das periferias por onde eu já andara. Éramos uma equipe ${ }^{67}$, e dispúnhamos de contatos cuja memória original das suas conexões com a vida dos coordenadores já me escapa. Cidade Tiradentes era longe, e imensa. Cada morador entrevistado pela equipe era um mundo novo: movimentos políticos combativos, relação com o universo dos perueiros, vida operária quebrantada pela reestruturação produtiva. Por outros caminhos passei, e quando retornei à Cidade Tiradentes o bairro já não parecia tão longe, e nem tão indecifráveis as suas histórias.

Chega-se a Cidade Tiradentes pela Estrada do Iguatemi, desaguadouro da Avenida Ragueb Choffi, que por sua vez "nasce" no final da Avenida Aricanduva. Do centro à Cidade Tiradentes, de carro, sem trânsito (num domingo, digamos), chega-se em uma hora e meia.

A Avenida Aricanduva abriga um grande shopping center da zona leste. Ao longo dos seus muitos quilômetros, da Penha até Itaquera, o olhar se acostuma com os grandes supermercados, grandes concessionárias, grandes centros automotivos (consertos, peças de todas as naturezas), grandes lojas de móveis e de eletrodomésticos, postos de gasolina, grandes igrejas, alguns bancos e algumas fábricas. Na Ragueb

${ }^{67}$ Neste parágrafo relato brevemente minha participação na pesquisa "“Mobilidades urbanas e trajetórias sociais: trabalho, moradia e mobilidade cotidiana", coordenada por Vera Telles (CENEDIC) e Robert Cabanes (IRD-Fr). Os resultados da pesquisa foram elaborados em Telles (2006). 
Choffi o comércio é parecido, embora o porte seja menor. Ali estão concentrados depósitos de materiais de construção e vidraçarias, lojas de móveis e eletrodomésticos, lojas para carros, um posto de gasolina, concessionárias pequenas, supermercados, e também lojas de roupas, açougues. Os "últimos" bancos da zona leste também ficam por ali. Na Estrada do Iguatemi o comércio é de outra natureza: olarias, ferros-velhos, borracharias, mecânicos e auto-elétricos. Neste entorno o aspecto é rural, há algumas casas em ambientes rurais e, num terreno mais extenso, uma favela.
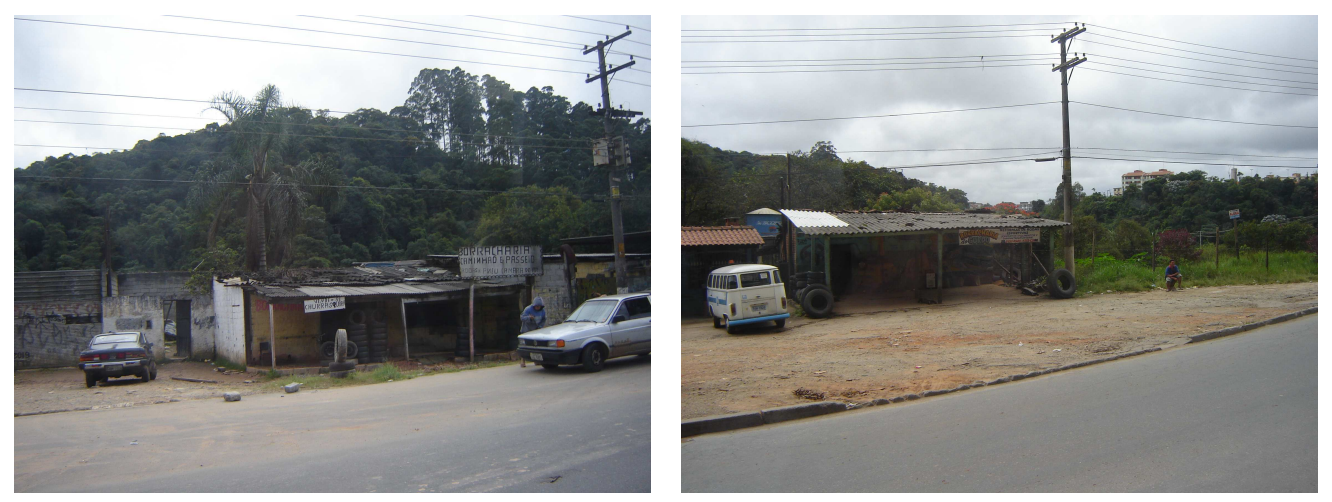

Estrada do Iguatemi.

Aprendi a identificar a chegada a Cidade Tiradentes com a referência do supermercado "Negreiros", o maior supermercado da região, dentro do qual situa-se a sub-prefeitura de Cidade Tiradentes. Dali num instante chega-se à Avenida Souza Ramos, cujo maior ponto de referência é a Igreja Universal do Reino de Deus, em direção ao Terminal de Ônibus da Cidade Tiradentes em cuja entrada situa-se o supermercado Barateiro. Estes comércios estão regularizados, segundo o engenheiro da sub-prefeitura.

Mais uma caminhada em ruas de morros, vendo edifícios de apartamentos, embriões e comércio em garagens e chegamos ao edifício em que foi realizada a pesquisa. O percurso a pé acostuma ao ambiente, e o olhar para os edifícios e para o comércio popular deixa de ser tão estrangeiro. Aos poucos a convivência com o campo é um hábito. Chama a atenção o odor desagradável de esgoto que surge inevitavelmente em algumas ruas. 
Tanto aos finais de semana quanto durante a semana Cidade Tiradentes está cheia. Há movimento no comércio, durante a semana e, nas ruas e bares, aos finais de semana. Em virtude da sua característica de distanciamento do resto da cidade, o bairro tem uma vida própria, em que pese o grande número de moradores que se deslocam cotidianamente para as regiões centrais para trabalhar. Durante a semana o movimento é de crianças que vão à escola e de pessoas atarefadas com suas atividades cotidianas. Aos finais de semana, jovens passeiam de carro ouvindo funks.

O edifício é uma das tipologias mais comuns na Cidade Tiradentes - 5 pavimentos e 3 escadarias, com apartamentos cuja área total equivale a $38,62 \mathrm{~m}^{2}$ (sendo $34,62 \mathrm{~m}^{2}$ de área útil e 4,00 $\mathrm{m}^{2}$ de área comum). De acordo com o relato dos moradores, sua construção data do início dos anos 1980. Cheguei a ele por meio de um morador que já era conhecido da pesquisa anterior (nota 67), um jovem engajado numa ONG e recém-casado. Ele me apresentou à síndica, Ilda, a quem conheci sabendo que era também, como a família deste jovem, militante do partido dos trabalhadores.

Evidentemente é mais confortável entrar num edifício para visitar algum conhecido. Os portões de entrada dos edifícios, no entanto, são quase todos abertos. Não há porteiros. Pelo hábito, descobre-se o nome das escadarias que identificam os apartamentos: A, B e C. Geralmente, sobretudo aos finais de semana há som. Os gêneros preferidos são pagode, funk e sertanejo, que disputam o espaço. Já ouvi também pop americano dos anos 1980, “top hits". Dependendo da hora, há cheiro de comida nos corredores, misturado ao cheiro de mofo. Quase todos os apartamentos mantém, além das portas, grades de ferro.
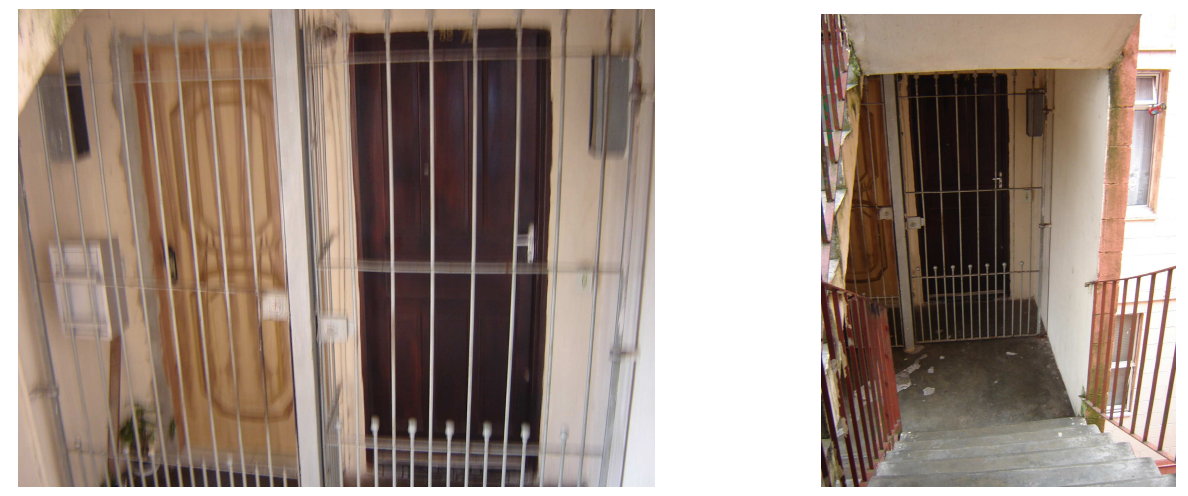
A partir da primeira inserção, entrevistando a síndica, fiquei sabendo que o edifício passava por uma reforma (que não terminara até a última visita que realizei, em março de 2009). À época em que foram realizadas a maior parte das entrevistas, entre 2006 e 2007, era o assunto principal dos moradores em relação à pesquisadora. Todos tinham um posicionamento em relação às obras, para revestimento das paredes e pisos, e reforma das áreas comuns, além da construção de outra entrada. Em geral criticava-se a morosidade do processo.

Outro ponto claro de questão que mobilizava os moradores era, como no edifício de Adriana, a partilha da conta de água, que é um problema que envolve diretamente o espaço coletivo e a forma como os indivíduos e famílias se relacionam com ele. $\mathrm{O}$ indivíduo (ou a família) pode priorizar o pagamento da conta, ou não, a considerar a medida que ele tem da importância desta conta. Pode ser uma medida puramente mercantil, considerando o cálculo do orçamento familiar, ou pode ser uma medida em que a natureza do serviço (um serviço coletivo), pesa mais. E, neste caso, conta a percepção do coletivo e a percepção do outro. Os que pagam a conta em dia sentem-se prejudicados por aqueles que não pagam, pois a inadimplência em algum momento resulta no corte do abastecimento, e na cobrança de multas e juros. É por isso que, neste edifício (como no de Adriana) os moradores optaram pela solução de individualizar a conta de água. Em cada apartamento foi instalado um relógio que controla o gasto da família. Excedido o prazo de pagamento, o abastecimento é cortado pela própria síndica. No sistema anterior, em que a conta era dividida igualmente por todos, o pagamento da conta por cada família dependia da importância que a família dava à sua contribuição com o todo, o que revela a medida que ela tem em relação ao que é coletivo. No sistema atual, esta decisão passa por uma coerção: o corte do abastecimento.

Atraso no pagamento da taxa de condomínio significa multa e juros. Com estas práticas, implementadas recentemente, a síndica buscou diminuir a inadimplência, de forma coercitiva. Como a participação dos moradores em reunião de condomínio é escassa as decisões são praticamente unilaterais. Isto, contudo, não significa consenso em relação às questões, mas a vitória do ponto de vista com maior força. O discurso anti-síndica é presente e intenso. Mas não se realiza como oposição dialogada. É antes 
um discurso de corredor, de reclamação, mas que raramente interpela a síndica diretamente. Em alguns casos é quase um rumor. Este discurso, que circula, mas não se converte em ação, revela que entre aqueles que o detêm, ele promove certa identidade, mas, ainda que inconscientemente, a situação é vista como dada, pois talvez os moradores esperem que alguém faça o papel de concentrar as críticas e propor soluções. É por isso que o espaço coletivo é um lugar de conversas, opiniões, expectativas, e uma liderança cristalizada.

Como Adriana, Ilda foi síndica do prédio durante a maior parte do tempo em que foi moradora. No caso de Adriana tivemos uma visão de sua experiência. No caso de Ilda a gestão do espaço coletivo é observada pela sua fala e pelas suas iniciativas, e completada por relatos de moradores que a apóiam ou não.

Ilda é uma mulher de cerca de 50 anos, mãe de três filhos, que criou sozinha. A sua figura é associada à militância político partidária (seja como identificação e apoio à causa, seja como crítica ao seu lugar supostamente vantajoso, visto com crítica).

A primeira conversa com síndica oscilou entre o relato de sua trajetória de vida e o relato das questões de condomínio, que se imbricam. A militância, a atuação no bairro e o papel de síndica foram acontecendo em sua vida em momentos diferentes, mas como um desdobramento natural, a partir do ponto de ruptura, que foi a sua separação. Como para outras mulheres de sua geração, a separação foi um ato de libertação. De fato, no Brasil dos anos 1950 e 1960 o casamento era uma opção quase que inquestionável para as jovens de todas as classes sociais. Da mesma forma, a separação anos depois significou para muitas mulheres a possibilidade de ampliar a atuação no mundo público, além do papel materno.

O ex-marido é visto por Ilda como um oponente a quem ela venceu. Esta relação de superação da mulher sem o apoio do marido, em contraposição a ele, foi recorrente em algumas trajetórias relatadas, que retratam os maridos como "perdidos" diante do mundo do trabalho que se tornou cada vez mais exigente e inteligível. A tolerância em relação a este homem, não mais o provedor da família, mas uma figura presente na educação dos filhos, foi variada em diferentes situações. No caso de Adriana, o marido permaneceu em casa e na educação dos filhos, mesmo sem ter o papel de protagonista. 
(Como no caso de Marta). No caso de Ilda, como no caso de D. Vera, as mulheres optaram pela separação. Esta questão de gênero, embora não tenha sido o foco das entrevistas de da pesquisa, é uma questão recorrente e pode remeter de fato a uma transformação do mundo do trabalho. Não apenas os empregos "masculinos", como também os "femininos" foram precarizados com a reestruturação produtiva. Este golpe foi, aparentemente, sentido com mais força pelos homens, talvez pelo fato de as mulheres estarem mais habituadas a trabalhos precários e menores salários, talvez pelo sentimento de responsabilidade em relação aos filhos ser mais indelével no caso das mulheres. São questões a serem consideradas não apenas em relação às políticas de habitação, mas ao conjunto de políticas voltadas à população de baixa renda.

Como a primeira entrevistada no edifício foi Ilda, as demais entrevistas seguiram-se indicadas por ela e ao mesmo tempo em referência a ela. Seja pela situação de entrevista, seja por ser a figura central no espaço coletivo, a figura de Ilda foi nos relatos um divisor de águas nas opiniões dos moradores. Discursos de apoio e de crítica foram delineando posições dentro do edifício, e permitiram compreender a postura de cada morador entrevistado em relação ao espaço coletivo.

Ao mesmo tempo, os rumores estavam presentes. A oposição explícita, também. Houve relatos de enfrentamento à síndica (como no caso de Macedo). Houve relatos de afastamento consciente das questões condominiais (como no caso de Igor). No entanto, não houve, durante a pesquisa, oposição organizada. Quais os limites da atuação no espaço coletivo? Mesmo por parte daqueles que se opõe, oferecer uma alternativa implica em busca de apoio, não apenas em expor uma idéia. E isto diz da forma como morador é visto. O morador que se opôs diretamente (Macedo) não é visto com credibilidade. Nesta visão de credibilidade, a visão de um certo status, além do espaço coletivo, mas da atuação do sujeito no mundo público, é levada em consideração. Macedo é pedreiro de pequenos expedientes. Ilda é funcionária pública e ligada ao partido político, assessora de um deputado federal. Estes vínculos orientam as opções dos moradores.

Além disso, a assembléia é esvaziada, o que contribui para a dificuldade de chegar a uma alternativa localmente, e o que dá maior peso aos atributos externos do 
que às questões concretas tratadas. Embora a assembléia seja tratada, no discurso, como um momento importante, na prática as atividades cotidianas não são interrompidas por uma assembléia. Os moradores justificam sua ausência com discursos que, em geral, desautorizam o espaço de debate, pois deslegitimam, no limite, os seus vizinhos. O espaço de debates é visto como um local onde quem vai "faz bagunça". Este olhar está em estreita consonância com a visão que as classes dominantes construíram ao longo dos anos sobre a participação popular, lugar de "bagunça". (Paoli, 2007). Talvez este discurso seja uma denegação da ausência de sucesso em momentos discursivos anteriores (as trajetórias dos moradores revelam históricos de fracassos profissionais e de fracassos diante da autoridade na figura do patrão, por exemplo). Em tudo é uma questão que diz respeito às formas como a apreensão do mundo público se dá, ao reconhecimento da atuação individual como a atuação de um sujeito histórico. A experiência da apreensão do mundo público advém da relação com as experiências coletivas, desde a escola. Uma educação que não problematize a reflexão do papel do sujeito na história orienta condutas que estarão sujeitas a outras referências, como as referências midiatizadas que fortalecem a estrutura de classes da sociedade e a visão hierarquizada das relações de trabalho. A apreensão de que o fracasso ou o sucesso são questões do indivíduo, e não questões produzidas socialmente, estão na raiz do entendimento de que o coletivo não tem força e estão também nos interstícios das desventuras de posições contrárias às hegemônicas. Estar na COHAB Cidade Tiradentes pode significar ter acesso a uma alternativa habitacional conduzida por outras instâncias, e ter a atuação condicionada a isto. É como se a atuação da COHAB-SP, fiscalizatória e administrativa, pautasse as relações coletivas em torno de questões mercantis.

\section{Os moradores}

Revestimentos em estado crítico (que passaram por uma reforma. Nas fotos, vemos os revestimentos após a reforma), músicas disputando o espaço, crianças brincando nas escadarias, grades nas casas, cheiro de comida no ar. Esta é a moradia de cerca de trezentas pessoas, distribuídas em sessenta apartamentos. Embora seja muita gente aos domingos, dias de vista, acostumo a encontrar as mesmas pessoas, que se vão tornando conhecidas; suas expressões e comportamentos, esperados. Os relatos 
evidenciam momentos de derrota e momentos de conquistas pessoais intensas. Há também uma esperança de um sucesso maior, que está fora da Cidade Tiradentes. Quase todos têm planos de uma vida fora dali.

Entre os moradores do edifício, situações de vínculo de emprego e momentos de vida distintos. Os vistos como quem teve mais sucesso são funcionários públicos (cerca de sete pessoas), cuja estabilidade ocupacional está garantida pela lei. Seguem-se, nesta pirâmide de percepção do sucesso profissional, os comerciantes informais, que produzem e vendem cocada e tapioca (cerca de seis pessoas), vistos como empreendedores. A atividade deles, embora semelhante, é informal e individual (não consideram a possibilidade de formar uma cooperativa). Outra categoria profissional presente com freqüência, e vista com menos brilho nos olhos, é a de empregadas domésticas (mulheres responsáveis pelo domicílio, tendo ou não companheiro), seguidas pelos viradores (as mulheres fazem bico na costura, cuidando de crianças, vendendo cosméticos, e os homens são pedreiros, eletricistas). São ocupações dos trabalhadores pobres, que participam de forma residual dos resultados da economia da cidade, do país e do mundo (já que muitas vezes estão ligados a núcleos de acumulação de capital de grandes empresas multinacionais, mesmo tendo uma participação extremamente residual nisso, como é o caso das mulheres que vendem cosméticos de porta em porta). Os servidores públicos prestam serviços à população da periferia, em escolas e unidades básicas de saúde, os trabalhadores ambulantes circulam pelas periferias e pelo centro antigo de São Paulo, comprando sua matéria-prima por atacado ali mesmo na zona leste, as empregadas domésticas trabalham em casas de família da zona leste de São Paulo, para famílias associadas a empregos de classe média (como bancários, por exemplo), e os viradores trabalham nas franjas das franjas do mercado de trabalho: na própria Cidade Tiradentes. São eles que vão até a Ragueb Choffi comprar canos para instalar no apartamento vizinho, por exemplo, ou compram blocos das olarias na Estrada do Iguatemi. Entre os jovens, um deles têm emprego como operário numa metalúrgica no $\mathrm{ABC}$, conquistado após o curso no SENAI (este é o único jovem que cursa o ensino superior), e o outro trabalha num posto menor qualificado numa indústria plástica na grande São Paulo. Os demais estão desempregados. Entre as jovens, contabilizam-se uma professora de ensino infantil da região, uma agente 
comunitária de saúde que atua localmente e desempregadas, às voltas com filhos pequenos.

Durante a semana os desempregados podem ser encontrados, levando crianças à escola (filhos ou netos), ou realizando alguma atividade de igreja. Aos finais de semana a maior parte dos moradores está em casa. As mulheres, fazendo faxina, cuidando dos filhos, cozinhando; os homens, às voltas com netos ou tocando cavaquinho na escadaria. As crianças, aos finais de semana, usam o espaço para suas brincadeiras, embora sejalhes interdito o uso do espaço comum para jogar bola, por exemplo. Elas ficam, geralmente, restritas às escadarias e ao espaço dos fundos.

Os moradores antigos são velhos conhecidos, e as relações entre eles são cordiais. Com simpatia referem-se uns aos outros, e em relações profissionais são lembrados e chamados para trabalhar. Apesar da cordialidade aparente, não houve momentos festivos. A construção de um salão de festas foi aventada por alguém, mas rechaçada por todos com quem eu conversei, que não queriam barulho por lá. Pode-se recorrer aos vizinhos em casos de necessidade (como uma emergência médica), mas isso é cada vez menos comum (era mais comum nos primeiros anos). Quem usa mais este tipo de solidariedade são os moradores mais novos, quando a relação de solidariedade é mais próxima (explicitada em caronas e momentos de atenção às crianças) talvez mesmo em virtude do ciclo familiar mais jovem, quando as crianças pequenas requerem atenções maiores.

\section{Personagens e cenas}

Ilda, a síndica, tomou conhecimento da COHAB-SP e do conjunto Cidade Tiradentes quando trabalhava numa empresa de limpeza que prestava serviços para a prefeitura. Logo que se mudou para o bairro, em virtude de sua atividade, conheceu muita gente e tornou-se conhecida. Ela trabalhava então na secretaria municipal dos esportes, cujos eventos atraem bastante público. Entrou na prefeitura na gestão Jânio Quadros (1985-1988). Nesta época, ela morava em Guarulhos, na grande São Paulo, em casa própria. Só saiu por causa da pressão do ex-marido, que queria seu dinheiro no 
imóvel. Neste ponto da entrevista ela comenta como o ex-marido, visto como um oponente, foi uma espécie de desafiante para o seu sucesso. Ela não se intimidou e mudou de vida indo para Cidade Tiradentes.

“(...)Aí, eu sempre sonhava, né, um dia eu vou ter um cantinho para mim, certo, mais próximo do serviço. Porque você sair de Guarulhos até aqui era. Ah, porque você não compra um apartamento da COHAB? Porque você não compra um apartamento da COHAB? Falei, não, eu tenho a minha casa, graças a Deus. Aí a ambição, não leve a mal, não, dos homens é a seguinte: a partir do momento que a mulher está com pouco tempo, cuidando de seu casa, sendo independente, começam a crescer os olhos, né. Aí meu marido começou a achar que eu estava evoluindo demais, certo. Os filhos chegavam em casa, a geladeira tinha de tudo, não precisava de nada, você está entendendo? Ele chegava em casa, as contas estavam pagas, as crianças estavam bem, né, aí começou ele a achar que ele já estava com uma certa idade, não arrumava mais emprego para ele poder trabalhar, ele estava com problema nos rins, precisava se tratar. Ele não tinha uma casa para ele, certo. Então ele achou de vender a minha casa, certo, para ele pegar a parte dele."

Quando se separou, ela fez a promessa a si mesma que pagaria aluguel por um ano apenas. Acionou a rede de contatos. Um colega que trabalhava com ela tinha um apartamento na Cidade Tiradentes para vender. Comprou e mudou, e só depois ficou sabendo com um conhecido da COHAB-SP que o apartamento tinha um débito. A COHAB-SP entrou com um processo e logo ela recebeu a ordem judicial de despejo. Novamente ela contou com o apoio de conhecidos para mobilizar informações sobre leis e normas, e, afinal, conseguiu reverter a ordem de despejo argumentando que a filha tinha uma doença nos rins. Quem a ajudou neste processo foi um advogado conhecido na época do Jânio. Mesmo antes da Cidade Tiradentes, Ilda orientava-se na sua rede de apoio formada por pessoas ligadas à administração pública, que usualmente têm mais mobilidade em se tratando de questões legais e relacionadas à políticas públicas. Este aspecto evidencia modos de acesso ao direito e às políticas: embora o acesso seja universal; na prática, alguns acessos são mediados por redes institucionais, dada a 
profusão de normas especificas e o caráter pouco claro da comunicação pública em algumas esferas.

Quando Ilda chegou à Cidade Tiradentes, apesar da sensação de insegurança que o local the provocou, foi aos poucos se habituando. Ela disse que o apartamento não tinha grades, e ela temia que a porta fosse arrombada e o apartamento fosse invadido enquanto ela estava trabalhando. Daí adveio a necessidade percebida por todos de reforçar a restrição à entrada com grades nas portas e nas janelas. A sua rede de relações em Cidade Tiradentes ampliou-se por meio da sua atuação como servidora da secretaria de esportes. Logo se tornou conhecida dos jogadores de futebol da região, de diversos times. O futebol é praticado em campos e quadras municipais, e agrega na mesma atividade homens e rapazes de vários cantos do bairro com inserções bastante diferenciadas (para citar duas inserções geralmente vistas como polarizadas, há traficantes e trabalhadores).

É interessante notar como nos dois casos estudados (de Adriana e Ilda), a presença no bairro foi fundamental no desdobramento da tomada do lugar de síndicas. Esta característica (passar mais tempo na Cidade Tiradentes) deve ter contato não apenas no momento em que elas passam a se dar conta das questões coletivas dos edifícios, mas deve ser importante na forma como os moradores as vêem como capazes de dar orientações a estas questões.

Quando Ilda assumiu a função pela primeira vez no edifício, a gestão coletiva passava por uma crise. Os moradores haviam contratado uma administradora que não pagava as contas e o resultado foi um corte no abastecimento e altas multas. Como solução, foi realizada uma rifa, iniciativa de Ilda. Como havia inadimplentes crônicos, os pagantes terminaram por pagar a conta de todos, com muita reclamação até os dias de hoje. Ilda foi fundamental neste processo de regularização dos débitos junto à companhia abastecedora de eletricidade, a então Eletropaulo.

Ilda teve este papel à época, mas depois afastou-se. Novo desfalque a colocou mais uma vez na posição de síndica. Desta vez, foi um débito na conta água que passou pelas vistas do Gérson da tapioca, síndico em 2004, e de todos os moradores. A solução encontrada por Ilda foi aumentar o valor do condomínio. Para acabar com a 
inadimplência instituiu juros altos ( $12 \%$ ao mês a partir do primeiro dia de atraso). Além disso, acirrou a postura em relação aos atrasos nos pagamentos da conta de água: após um mês de atraso a água é cortada.

Sua gestão é, portanto, "linha dura". Ela se faz presente e assume medidas restritivas. Seu entendimento é de que é necessário implementar critérios claros nas questões coletivas, e, ao mesmo tempo, que possam coagir todos a fazerem a sua parte. Ela não se preocupa em ser bem vista, mas apenas em organizar as contas e propor as reformas.

Ilda, assim como Adriana, conhece todos os moradores. Numa ocasião, ela fez um "mapa"de todos os apartamentos, descrevendo quem morava aonde, quais eram as relações entre os moradores de um mesmo apartamento (as mais diversas situações: irmãos, casais e filho, casais, filhos e sogros, ou genros, ou além disso primos, rapaz solteiro, moça solteira, mãe separada ou viúva e filhos), qual era a situação do apartamento (quitado, mutuário, primeiro morador, segundo ou terceiro morador, alugado, recebido em herança), quais eram as atividades profissionais dos moradores (funcionários públicos, empregadas domésticas, costureiras, ambulantes, tapioqueiros, pedreiros, operários, traficantes) e discorreu sobre a história de algumas famílias. Foi por meio dela que foi possível compreender como os apartamentos são apropriados assim como muitos quintais de famílias das periferias. Uma família nuclear cria os seus filhos, os filhos se casam e moram junto aos pais e sogros por algum tempo, até que surja a oportunidade de alugar ou mesmo comprar um apartamento do mesmo prédio). Há pelo menos três famílias que moram em pelo menos uma dezena de apartamentos no prédio.

Ilda é uma figura que conquistou seu reconhecimento e seu espaço político na Cidade Tiradentes, mas não se identifica muito com os moradores dali. Ela vê a Cidade Tiradentes como resultado de um fenômeno urbano de "inchamento" da cidade provocado pela intensa migração, ou seja, de crescimento da cidade em função de migrantes que chegam "na tentativa de vencer na vida". Ela vê os moradores do prédio e da Cidade Tiradentes como pessoas que buscaram um futuro melhor, mas que foram iludidos pela cidade. 
"Você vê. E eles ainda colocam na cabeça que ainda há a possibilidade de você vencer aqui em São Paulo. Já acabou isso. São Paulo já não tem mais condição de, aliás, o Brasil inteiro, né. Você vê a deficiência que existe. Ainda mais você sair da sua cidade $e$ se alojar bem lá longe. Em Cidade Tiradentes, você pode ver. É uma tradição do Norte mesmo, certo, é uma tradição do Norte mesmo. São pessoas que saíram de lá com o intuito de vencer aqui. Alguns conseguiram. Então aquela que veio primeiro, eu posso falar, por exemplo, tenho aqui 51, 52. Ele veio primeiro, certo, ele arrumou emprego, ele é hoje funcionário público, ele já trouxe uma irmã, já trouxe a outra irmã, você está entendendo, já trouxe a mãe, certo, através da mãe já veio o sobrinho, já veio outro sobrinho, você está entendendo, tudo com esperança de conseguir aqui o mesmo que essa pessoa conseguiu. Porque é assim, eles tem ainda na mente que se eu consegui ter um emprego fixo, eles também vão conseguir, você entendeu? E aí é onde incha, certo. Incha, por exemplo, de ter em um apartamento desse, certo, hoje mora eu e meu filho, já moraram os dois casados, certo, os meus dois casados já, cada um tem o seu local e a sua estabilidade, certo, quer dizer que meи apartamento desinchou mas acresceu para outro lado, certo. Agora, se eu tivesse a minha mãe, se estivesse viva e estivesse, por exemplo, lá no Norte, o que eu ia fazer nesse apartamento, certo. Se a minha irmã estivesse lá no Norte, eu ia trazer ela para cá. Ia trazer minha mãe. Então, quer dizer que na realidade, eu não ia, por exemplo, expandir, ia sufocar mais. Eu não ia desvaziar, ia trazer para cá para sufocar mais.”

Mesmo que a realidade de Cidade Tiradentes não seja eminentemente de migrantes, este é praticamente um mito constitutivo da zona leste da cidade, tanto no imaginário das classes médias quanto no imaginário dos próprios moradores da Cidade Tiradentes. Ancora-se no momento histórico em que os migrantes chegavam intensamente a São Paulo (anos 1970 e 1980) e muitas vezes é associado a discursos preconceituosos.

Ilda aprendeu a lidar com os códigos locais. Compreendeu que o tráfico de drogas é uma realidade e aprendeu a conviver com os traficantes no campo de futebol e 
nas imediações. Ela desenvolveu uma espécie de respeito pelas atividades deles, tanto quanto eles aprenderam a respeitá-la no bairro, ela conta.

Foi por intermédio de Ilda que conheci as pessoas com quem viria a conversar a seguir no prédio: Marta, Ivani, Assunta e Ana.

De maneira geral, as pessoas foram cordiais e receptivas. Fui recebida em seus apartamentos e me ofereceram lanches, café, sucos e almoço. Com o tempo, já sabendo de minha presença no final de semana e da distância da padaria que oferece refeições, algumas famílias conhecidas me ofereciam almoço. Os conhecidos eu encontrava às vezes na rua. Acenos, abraços, muitos pareciam contentes em conversar comigo e contar os desdobramentos de alguma situação em pauta, familiar ou do bairro. Houve também algumas experiências de recusa da entrevista, contudo. Ivani, logo no início do campo, é a moça que faz a entrega das correspondências para Ilda. Magra, agitada, concordou com a entrevista e marcou uma data. No dia agendado encontrei-a em meio a uma faxina no apartamento bem acabado, com móveis novos e decoração religiosa. Convidou-me para entrar e tentei entabular alguma conversação, ao que ela respondia "não tenho nada a declarar". Estranhei sua recusa ter acontecido após uma introdução, mas respeitei. Continuei encontrando-a a maior parte das vezes que estive ali, mas mesmo assim não houve abertura. Noutra oportunidade, meses depois, cheguei a conhecer o citado Gerson da cocada, figura lembrada em muitas outras conversas, como quem começou o negócio da tapioca, seguido de outros moradores. Fui apresentada a ele nas garagens, por Igor, uma das pessoas que trabalha com tapioca. Procurei explicar minha presença ali convidando para uma entrevista, mas ele foi bastante esquivo, respondendo que "não tinha horário", não adiantaria tentar encontrá-lo, ou pegar seu número de telefone. A outra recusa foi de um morador antigo do edifício que trabalha num órgão policial, até onde foi possível entender. Conheci o apartamento, vazio, chão de terra batido, com um colchão e uma cadeira na sala mal pintada. Ali moravam também a filha, o genro e dois netos, além da mulher. A mulher trabalhava como empregada doméstica, dormindo no emprego. A filha, desempregada, esquivou-se das conversas. Casada com um motoboy, jovem, estava sempre às voltas com atividades domésticas, carregando roupas para pendurar no varal coletivo ou varrendo o chão. Agendei umas duas ou três visitas com seu pai, que nunca estava presente na data e hora 
marcada. Afinal ele disse-me que não era seguro para ele conversar comigo, dada sua profissão. Duas moças jovens também se recusaram, uma argumentando dificuldade de agenda, e a outra, sem cumprir horários e datas marcados, praticamente "desaparecia". A primeira era agente comunitária de saúde, e morava com a irmã num apartamento no último andar. $\mathrm{O}$ apartamento estava em obras. Macedo recentemente construíra uma parede ali, conforme me contara. A parede estava nos blocos, sem qualquer revestimento de cimento. Amanda, uma moça na faixa dos 25 anos, fazia tranças no cabelo no dia em que a conheci, mas disse que era um dos raros momentos em que estava em casa, pois, em todo o seu tempo livre, acorria à igreja evangélica em que participava dos teatros. Letícia morava sozinha, tendo herdado o apartamento de sua mãe viúva. Sua situação de mulher solteira morando sozinha suscitou minha curiosidade, mas ela não estava no dia marcado da entrevista e nunca mais a vi no edifício.

A cada dia em campo entrevistava uma ou duas pessoas. Muitas vezes, não entrevistava ninguém. À medida em que os meses se passavam e eu conhecia mais famílias, os sábados ou domingos eram momentos de visitar as famílias conhecidas e tentar conhecer mais alguém. As recusas, assim, eram minimizadas pela acolhida de outras pessoas.

A seguir, exponho algumas trajetórias escolhidas entre as entrevistas realizadas, por refletirem momentos significativos nas relações com o mundo público e com o espaço coletivo. Os aspectos sociológicos que as trajetórias suscitam são levantados no sentido de delinear as relações destes personagens com as cenas e o espaço coletivo.

\section{Marta: as contradições do trabalho doméstico}

Os móveis da sala são antigos e revelam o desgaste do tempo. O piso foi trocado há anos, e sofreu algumas quebras. A pintura da parede também está desbotada. A sala têm um móvel para a televisão, de 20 polegadas, e um sofá de dois lugares. Na sala estão Marta, uma mulher baixa e troncuda, com expressão séria e cabelo curto, se aproximando dos seus 50 anos, e sua filha, uma moça com ares adolescentes, às voltas ela mesma com sua filha, uma menininha de uns quatro anos que anda pra lá e pra cá na escadaria. Completam a cena familiar Jair, um homem magro e de aspecto desolado, 
também ele geralmente cuidando da neta, e um cachorro magro que tem acesso livre às escadarias e dali à rua. Noutro plano, o genro, um rapazote agitado e o filho, operário de uma indústria plástica numa cidade da grande São Paulo, presente em todas as falas mas que não cheguei a conhecer. Quando não está trabalhando, está na casa da namorada, segundo a mãe.

Marta trabalha como empregada doméstica e praticamente mantêm a casa, o marido, o filho e a filha, o genro e a neta. Passa a semana fora e, ao chegar em casa, trabalha. Seu marido e a filha passam a maior parte do tempo em casa, com a criança. Jair realiza uns "bicos", mas são esporádicos. A filha não trabalha e não busca trabalho, envolvida na criação da menina. O genro, quando o conheci, estava desempregado e era visto pela família e pela própria esposa como uma espécie de "estorvo", relacionado à sua passagem por uma penitenciária. Durante as minhas visitas, ele arrumou um emprego. Marta é a provedora da família, aquela pessoa conhecida como "chefe de família", responsabilidade que divide parcialmente com o filho. Suas posições são claras e em seu discurso não há espaço para lamentações ou para exacerbações. A fala sobre si própria é objetiva e racionalizada, mesmo ao falar dos dramas pelos quais passou.

Um dos dramas diz respeito ao fato de que a vida voltada ao trabalho dificultou o seu acesso aos filhos.

A trajetória ilumina a situação de muitas mulheres que são responsáveis por domicílio, que mantêm a casa; e ilumina também a vida de muitos expedientes que cruzam a trajetória familiar, como o contato com atividades ilegais e sua elaboração pela família. Ilumina também uma vida que ganha sentido com a maternidade, e que longe dela não vê muitas perspectivas, como no caso da filha de Marta. Ou ainda o percurso errático de um operário que ficou para trás na modernização das relações na construção civil e vive do comércio ambulante, às voltas com a decisão da prefeitura sobre o uso do espaço da cidade (povoado por propinas e pela falta de garantia).

A trajetória de Marta esclarece uma das formas de trabalho mais presentes na vida das mulheres pobres brasileiras: o trabalho doméstico. O trabalho doméstico é a 
forma de trabalho de 6,5 milhões de brasileiras ${ }^{68}$ e constitui uma ocupação em que os saberes são desvalorizados duplamente, segundo Cabanes \& Georges (2007), uma vez que são femininos (com toda a carga de preconceitos históricos que isto traz) e, além do mais, trazem, mesmo que redefinidos, alguns resquícios da escravidão. Dentre as empregadas domésticas, há aquelas que trabalham sob a mediação da profissionalização legal (com a "carteira assinada"), há aquelas que são eventuais e recebem por dia (as faxineiras) e há ainda as que trabalham sem vínculo profissional. A rede de conhecimentos gerada por trabalhos anteriores é indispensável para garantir a recolocação na ocupação. Por outro lado, trabalhar mais próximo ao bairro, implica em geral trabalhar por uma remuneração menor, como o que ocorre com mulheres jovens, cuja rede de "patroas" é pequena ou inexistente.

No trabalho doméstico são freqüentes os relatos que evocam a ausência de limites profissionais entre patroas e empregadas, numa lógica que em algumas situações é de apoio, em algumas situações de exploração (seja da força de trabalho, seja da intimidade de quem emprega). Para Marta o lado mais duro do trabalho doméstico foi o sentimento de negligenciar os próprios filhos. Marta diz que não pôde criar os próprios filhos, mas teve que ajudar a criar os filho das patroas, num sistema do qual ela discorda:

“(...)hoje em dia, numa casa de família, a pessoa não tem tanto valor que nem numa firma. Sendo que o serviço doméstico é pior do que trabalhar numa firma. É bem pior. Ou é igual. Eles não tinham que comparar serviço doméstico, trabalha em casa de família e não é pesado. É. Quem disse que não é? A patroa quer que você lava, passa, cozinha, limpa, cuida de criança e entrega tudo na tua mão. A patroa sai pra trabalhar e entrega a casa na tua mão. E quer que lava, passa, cozinha e cuide de filho ainda. E filho dos outros não é fácil você cuidar. Não é fácil você cuidar de filho dos outros. Ainda mais filhos de pessoas assim que trata os filhos como... As patroa, hoje em dia, trata... As mães de hoje trata os filhos como bebiló [Quis dizer bibelô], entendeu? Aí, a mãe sai elas denga, mima, sai deixa na mão da gente e a gente é que se ferra. Você não pode bater, você não pode educar

\footnotetext{
${ }^{68}$ Dados da PNAD 2004 citados por Cabanes \& Georges (2007).
} 
os filhos dos outros. Se você for educar, entendeu? Eles não admite que você educa os filhos deles da sua maneira. Tem que educar que nem eles, mimando. Mas você não vai ter tempo pra ficar mimando o filho dos outros, né?"

No trabalho doméstico, a mulher está próxima demais da vida privada da empregadora, chamada de "patroa", e o trabalho é carregado de afeto, e o ressentimento, mesmo inconsciente, tem o seu lugar. No depoimento de Marta, fica evidente o ressentimento que ela nutre por ter-se afastado dos filhos, embora estivesse o tempo todo com crianças em relação às quais ela não se considerava responsável. Enquanto ela não pôde educar os filhos, os filhos da patroa eram "mimados".

“(...)Entendeu? Aí, hoje, todos vão pra psicólogo. Mas por que as crianças tão indo pra psicólogo? Uma vez, o médico de um deles chegou em mim e falou: "Ó, mas eu acho que se essa menina, se hoje eles tão precisando, você é culpada". "Por que que eu sou culpada?" "Ah, você fica o dia inteiro com eles". Agora, as crianças tão tudo... por que que umas criança nessa idade precisa de psicólogo? Eu falei: "Ah, por que? Porque a mãe quando chega do serviço, mima demais. Faz tudo o que os filhos quer". Os filhos cresce tudo assim: se você não faz a vontade deles, sabe como é o negócio? As crianças é tão mimada, tão mimada, que quando a mãe chega - você precisa ver como trata as crianças - "oi, meu filho, tudo bem?" (Marlene imita a voz da patroa), começa, sabe? Aquela frescurinha de mãe, né? Aí, as crianças, às vezes, quer uma coisa que você fala: "não pode". Mas, a mãe dá e quando você não dá, as crianças vêm pra cima. "Minha mãe dá por que você não dá? Aí, ficam aqueles mimos. Aí, hoje, vai tudo pra psicólogo. Por que vai pra psicólogo, entendeu? Porque se você não der uma educação pra uma criança - não precisa bater, não precisa ser áspero - mas também não precisa ficar só mimando, dengando, você entendeu? Daquele jeito que hoje as crianças tá tudo indo pra psicóloga. Aí, fala: "Mas, você"... O médico de um deles chegou em mim e falou: "Você que é culpada. Você também deve mimar demais". Eu disse: "Eu? Você acha que eu vou ter tempo de mimar? Me poupe", falei pro médico. "Eu não tenho tempo pra ficar mimando criança”. Não mimei nem os meu, vou mimar filho dos outros?" 
As contradições são evidentes e, como a convivência é muito próxima, assume tons carregados de afetividade. O raciocínio logo se liga ao que ela entende como conseqüências de seu distanciamento dos filhos. Marta responsabiliza-se pela gravidez precoce da filha, e avalia que o marido foi incapaz de educar os filhos. O marido de Marta é visto por ela como um homem sem muito afinco para o trabalho, e é quase como um filho a mais de quem ela precisa cuidar.

É uma vida repleta de responsabilidades, e ela não assumiria uma responsabilidade a mais em relação ao espaço coletivo, por exemplo, embora corrobore com as atitudes de Ilda.

“(...)Porque ela administra bem. Ela sempre administrou e ela administra bem. Ela faz tudo ali no... Apesar que alguns discordam. Uns fala que ela rouba, outros fala que ela tá tirando muito, entendeu? Mas, você sabe, o povo eles arruma pra tudo, sabe assim? Eles põe defeito em tudo. Mas, se você falar, então, fica você na administração, vai você cuidar do prédio, cuida você. Se fosse acha que você tem capacidade, então, vai você. Enfrenta. Porque não é fácil."

A trajetória de Marta pode ser compreendida à luz das discussões colocadas por Cabanes (2006), quando descreve as relações de gênero em relação ao mundo do trabalho e à vida privada. O fenômeno da ampliação da presença das mulheres no mercado de trabalho permitiria a reestruturação de relações de poder no ambiente privado, superando a figura da autoridade paterna investida na figura do chefe provedor. Esta figura está em declínio, como é o caso nítido do marido de Marta. A relação entre os cônjuges, na argumentação de Cabanes (2006), abriria espaço para uma relação mais horizontal. No caso de Marta, contudo, o declínio do marido foi substituído por uma sobrecarga de trabalho e responsabilidades.

Marta é ativa no mundo doméstico e familiar, central mesmo. Sua trajetória, por outro lado, demanda sua presença constante no trabalho e em casa, retirando sua possibilidade de atuação no espaço coletivo. Ao marido, que tem disponibilidade de tempo, já que trabalha eventualmente, falta talvez confiança e interesse em assumir as 
questões coletivas. Sua postura é de quase anulação. Quando tentei entrevistá-lo lê usualmente dizia, "fale com a Marta, espere ela chegar". Fora do apartamento, nas escadarias ou na laje, distante do gravador, ele contava que foi eletricista de empresas de construção civil até ser demitido e passar a viver de "bicos", pequenos expedientes. É neste papel que ele se coloca no espaço coletivo, como alguém que pode fazer serviços e está disponível para isso. Durante a pesquisa, sua atividade econômica principal era como motorista de Gérson da tapioca.

\section{Um discurso de tristeza}

Em seguida à entrevista de Marta conversei com D. Assunta. Ela não me recebeu em seu apartamento, mas conversamos num banco na praça, na rua em que mora. De outras vezes que tentei conhecer seus filhos, a porta do apartamento foi entreaberta e ficou claro que eu não era bem vinda no seu espaço doméstico e familiar. Mãe de seis filhos, filha de pais paranaenses, teve uma vida sofrida e seu discurso é em tom de lamento. Criou os seis filhos na Cidade Tiradentes. Trabalhou muito - vendendo roupas, vendendo coxinha - mas não vê as atividades como trabalho, como é comum no trabalho feminino popular, compreendido como atividades para "ajudar o marido", praticamente extensões da vida doméstica que não implementam presença no espaço público. Sua trajetória constitui-se junto ao marido, mas ela fala pouco sobre ele. Fala rapidamente de sua doença e sua morte, como quem não está disposta a elaborar o luto. Dos seis filhos, quatro "saíram para o mundo", com maior ou menor sucesso. Dois filhos ficaram com ela no apartamento da Cidade Tiradentes, um deles tem síndrome do pânico. Busquei meios de conhecê-los, mas ela os protegeu. Em tudo resignada, falou pouco sobre os vizinhos e não emitiu opinião sobre a síndica. 
A trajetória de D. Assunta ilumina uma história de ausência de uma rede de proteção social e seus efeitos à falta de recursos privados. Aparentemente, a perda do marido significou também uma dificuldade de acesso ao mundo público, seja por meio do trabalho, seja por meio da possibilidade de refletir sobre as questões do espaço coletivo para além de suas referências privadas.

\section{Um relato de conversão}

Num domingo destes de trabalho de campo bati à porta de D. Vera. Ela havia sido apresentada a mim por Marta. Com olhar doce, voz baixa, e longos cabelos lisos, esta mulher de meia idade questionou sutilmente de onde eu era e a que vinha e por fim abriu o delicado equilíbrio de seu lar para meu convívio. Entrei no apartamento impecável, cheirando a lavanda, com pisos claros recém-trocados, paredes pintadas em tons pastéis, uma mesa de vidro, um móvel para a televisão, um sofá colorido e uma mesinha com um computador, além de objetos de decoração que lembrariam um quarto de menina-moça.

Mostrei-lhe a carteirinha que me vinculava à universidade, citei as pessoas com quem havia conversado e ela convidou-me a sentar e ofereceu-me café com leite. Nas visitas seguintes ao prédio, o momento do café com leite e bolachas na casa de D. Vera tornou-se freqüente.

Filha de lavradores cearenses, D. Vera morou no interior do Maranhão, trabalhando na roça e depois na cidade. Da vida na roça trouxe à memória os tempos de rudeza. Apesar da rigidez do pai, pôde estudar o equivalente ao ensino médio (fato incomum, sobretudo para mulheres no sertão à época). Casou-se jovem, aos 18 anos. Viveu com o marido seis anos em São Luis, ele, alfaiate, ela, estudante. Veio a São Paulo morar na rua Augusta, na década de 1970. Era uma vida de gastos comedidos, mas confortável. Mesmo sem necessidade, decidiu trabalhar em uma oficina de costura no Brás, movida pela curiosidade com a cidade, com o mundo do trabalho. Relata um episódio em que, em função do sotaque, foi maltratada no trabalho, quando era secretária numa escola de inglês. Ela conta este episódio sem humilhação, mas consciente da injustiça do fato. À esta época, morava na Praça da República, num apartamento alugado. O marido montou uma oficina, mas bebia muito e o casamento 
desandou, até o episódio traumático em que ele foi esfaqueado durante uma briga, e logo em seguida adoeceu de tuberculose. D. Vera responsabilizou-se pelos cuidados com o marido. Sem a renda dele, o trabalho dela ficou imperativo, e o orçamento não conseguia manter o padrão de vida. Foram morar na COHAB José Bonifácio, em Itaquera. Quando o marido melhorou voltou a trabalhar, montando a alfaiataria do minúsculo apartamento. Decidiram adotar uma criança para tentar salvar o casamento. $\mathrm{Na}$ mesma época, sua irmã estava grávida e o bebê nasceu prematuro e com problemas respiratórios. Foi quando D. Vera decidiu adotar a criança, o que coincidiu com o seu retorno à igreja, pois ela conta que naquele momento reencontrou a fé em Jesus e no evangelho. Registrou o filho, mas a irmã cuidava do neném. Sentiu-se compelida a afastar a irmã da criança para poder assumir a maternidade. Anos depois, o filho, de pele mais escura do que a sua, $\log$ o se viu diferente dos primos e ela contou a história a ele. Do apartamento emprestado na COHAB José Bonifácio foi com o marido e o menino para o apartamento na Cidade Tiradentes, sorteado (a inscrição era dos anos 1970, início da vida em São Paulo). Foi demitida do trabalho por rebeldia (cantou "o cordão dos puxa-saco" quando o encarregado obrigada as costureiras a trabalhar durante um apagão) e ficou algum tempo sem trabalhar, vivendo problemas no casamento.

Os sofrimentos foram muitos: sem dinheiro, com filho pequeno numa Cidade Tiradentes sem infra-estrutura, com vizinhos que pareciam "um bando de índios" (o tom é pejorativo e revela seu desejo de distinguir-se dos vizinhos). Viveu com o marido ainda nove anos após o nascimento do filho, quando decidiu separar-se dele. Após a separação a vida voltou a se organizar. Prestou concurso para auxiliar de desenvolvimento infantil na própria Cidade Tiradentes, contribuindo na educação de crianças que hoje já são pais.

No caso de D. Vera, a separação foi um alívio e trouxe a organização da vida que ela buscava: trabalho estável no serviço público, cuidado com o filho e posteriormente com a sobrinha e a vida comunitária na igreja evangélica.

D. Vera dedica-se integralmente ao filho, jovem operário que cursa a faculdade de psicologia, e à sobrinha, professora de educação infantil. Suas atividades diárias são o trabalho, onde o cuidado também é evidenciado (ela é assistente de educação numa 
escola de ensino infantil), e o cuidado com a casa. Aos finais de semana, os três dedicam-se à igreja, recebem pastores, fazem orações em casa. O envolvimento com o espaço público está um pouco distante das preocupações de D. Vera, que mantém seu mundo porta adentro do apartamento, com via de entrada para quem é da igreja. Relaciona-se cordialmente com os vizinhos, mas não participa das reuniões de condomínio e provavelmente não aceitaria o desgaste de ser uma referência no espaço coletivo.

Em que pese seu não-envolvimento, D.Vera é mais crítica em relação à síndica do que D. Marta, por exemplo, no que tange ao que toca diretamente ao seu espaço. Não está satisfeita com a leitura da conta de água "a gente faz de tudo pra diminuir e não diminui" e nem com a reforma do prédio, e avalia que a síndica recebe salário pelo trabalho, mas não se dedica o suficiente. Talvez a sua queixa seja diante da postura de Ilda, menos sutil do que ela entende que deva ser a postura de uma mulher.

Para manter seu apartamento na Cidade Tiradentes, D. Vera se preparou. As brigas com o marido se acirraram e ela suportou até sair a separação judicial. O marido não queria abrir mão do apartamento e pressionava-a para que vendessem o apartamento e dividissem o dinheiro. D. Vera acreditava no apartamento como seu porto seguro, e foi juntando dinheiro até a separação judicial. Quando esta aconteceu, ela pagou a parte dele do imóvel em juízo.

O relato de D. Vera ilumina uma história de decepção no casamento e decepção com os homens em geral. No seu relato, ela conta de um encontro com um homem, quando estava separada, que a desapontou. Em lugar de arriscar-se no romance, ela preferiu voltar à igreja ${ }^{69}$. A religião é fundamental na sua vida, na vida do filho e na vida da sobrinha, que moram com ela.

Dona Vera: Então, quando...Desse decorrer da separação, eu... Teve uma época na minha vida que eu tava com muita depressão porque eu não era feliz. Eu... "Meu Deus, eu tenho um filho. Meu filho tá crescendo. Meu filho já tá um pré-adolescente"... Tava com dez, com nove

${ }^{69}$ A igreja que D. Vera freqüenta é neo-pentecostal. 
anos já. (...)"Meu Deus, qual é o futuro do meu filho?” E eu sozinha. Eu queria porque queria companhia.

Foi quando conheceu um rapaz, encontrou-se com ele mas decidiu-se pelo distanciamento.

Pesquisadora: Durou muito tempo esse romance?

Dona Vera: Ah, eu acho que uns três meses. Uns três meses só. E eu ali e com aquela angústia no meu coração, aquela tristeza, aquela coisa terrível que eu não sei nem te explicar o que que era. (...) Mas já era Deus trabalhando na minha vida, viu? E eu só sei que eu assisti aquele filme. Cheguei em casa, o meu filho dormindo, eu olhei pra ele assim: "Ai, Jesus, eu não quero continuar com essa vida. Isso não é vida pra mim. Eu não nasci pra viver essa situação”. Aí, fui na janela do meu quarto e falei assim: "Meи Deus, eи quero que você mude a minha história. Eu quero que você mude a minha situação. A minha história porque eu não quero continuar nessa mentira”. Aí eu fiquei. Isso foi numa sexta-feira, quando foi no sábado, no Domingo, eu fui pra Igreja. Eu era... Eu tinha sido criada no Evangelho. Eu tinha falado com Deus que eu queria que ele mudasse a minha história. E eu sempre falava assim que a minha família tudo é evangélica.

\section{(...)}

Naquele noite de Domingo, eu fui e sentei no último banco daquela Igreja. Quando eu sentei ali que o Pastor começou a ministrar a Palavra, minha filha, a Palavra veio todinha pro meu coração. Veio toda pro meu coração. Eu chorava, eu sabia que era Deus que tava falando comigo. Tudo aquilo que tava passando, aquele processo de infelicidade, de desilusão, de um monte de coisa que eu sentia, de tristeza, aí naquela noite eu aceitei Jesus como meu Salvador.

\section{(...)}

$E$ as provas vieram e Deus colocou pessoas maravilhosas no meu caminho. A minha sobrinha é uma pessoa que Deus colocou na minha vida, que 
eu com a minha sobrinha nós temos uma comunhão plena. Graças a Deus. Colocou irmãos e irmãs da Igreja, que hoje eu considero como filhos. Que pena que eles não tão aqui pra confirmar isso, que são umas benção na minha vida. E os meus vizinhos também que são umas benção. Tirando as dificuldades, mas é com as dificuldades que a gente aprende, ne? E eu tô aqui, Graças a Deus".

O discurso de conversão de D. Vera é emocionado. Na igreja ela encontrou acolhimento por meio de um discurso redentor e reconciliador. A igreja demanda um comportamento moral ilibado, e nesta troca entre os pequenos gestos morais (o celibato) e a comunidade da igreja, ela diz sentir-se realizada. $O$ amor humano passa a ser depositado no seu filho. Além de amá-lo, ela orgulha-se dele. Renato iniciou um curso superior na área de psicologia e em seu relato nota-se a satisfação que ele tem com o emprego como operário e com a igreja.

Toda sua vocação pública D. Vera realiza no trabalho e na sua comunidade religiosa. Sua relação com os vizinhos é de simpatia, mas ela nutre o desejo de partir da Cidade Tiradentes. Sua participação na escola e na igreja é como evangelizadora, mas ela abdica de fazê-lo no espaço coletivo, em que as resistências são maiores.

\section{Uma jovem mãe de família}

O apartamento é abaixo do térreo, o que lhe garante um pequeno espaço anterior à escada que não existe nos outros. Neste espaço três galinhas cacarejam em meio a quatro meninas que brincam. A sala é pintada de um verde caiado, o sofá velho é o único móvel do local. Sentamo-nos as seis, Ana, eu, e suas quatro filhas pequenas (a mais velha na faixa dos quatorze anos). Ana é também filha de nordestinos e trabalhou como garçonete até encontrar o marido e estabelecer-se na Cidade Tiradentes. Sua ocupação são as filhas e o trabalho como tapioqueira. Seu marido é garçom no centro da cidade. Foi por intermédio dela que conheci os tapioqueiros do prédio. A situação da entrevista, com as crianças presentes, não permitia grandes reflexões ou mesmo que Ana transcorresse sobre sua vida. Comentamos sobre Cidade Tiradentes, e as meninas 
foram unânimes em afirmar que o bairro é ótimo, encasquetadas com a minha presença ali, acreditando mesmo que eu fosse alguma jornalista e que a entrevista tivesse alguma relação com a televisão.

\section{A tapioca}

A tapioca é um elemento importante na vida coletiva do prédio Ao menos seis famílias estão envolvidas na produção e venda da tapioca. De origem indígena, bastante comum no nordeste e vendida no comércio informal em São Paulo. O comércio da tapioca no prédio é o ganha-pão de pessoas como Igor, Ana, Julio, e Gerson.

Gerson é a grande referência da tapioca no prédio. Quem me apresentou a ele foi Igor, quando descemos para que eu conhecesse sua garagem onde os mantimentos são guardados e a iguaria é produzida. Gerson estava trabalhando em sua própria garagem. Aproximei-me, apresentei-me e propus uma entrevista. Ele foi esquivo e disse que seria impossível conseguir um horário para conversar. Talvez a negativa de Gerson tenha vindo da preocupação em falar sobre o período em que foi síndico e o em que o prédio sofreu com o corte no abastecimento de água.

Por meio do relato dos demais fui informada de que Gerson foi o primeiro a trabalhar com a tapioca no prédio, produzindo-a ali mesmo, numa garagem, e vendendo-a na feira. Aos poucos outros moradores tomaram conhecimento da produção e se interessaram pela atividade.

Igor vende tapioca em feira, Ana vende como ambulante no bairro da Santa Cecília e Julio trabalha como motorista de Gerson. Há uma rede de solidariedade, pois a informação sobre fornecedores e preços circula entre eles. Embora a atividade seja a mesma e algumas informações circulem, eles não consideram a possibilidade de formar uma cooperativa. 
Entre os personagens envolvidos com a tapioca está Julio, marido de Marta. Está sempre pelo prédio. Eletricista, viu sua carreira desandar quando o cerco do neoliberalismo apertou os empregos. Vive como motorista de Gerson, da cocada.

O exemplo de que uma atividade de ambulante pode ser vista como um caminho para o sucesso adveio do relato de Igor, morador do edifício.

\section{Um relato ascendente: a tapioca de Igor}

A decoração não tem muitos adereços. A televisão e o computador são os elementos centrais da sala no apartamento de acabamento bem feito. À minha frente está Igor, de camisa e calça social, com sua presença forte e seus óculos de aro fino.

Igor inicia o relato falando que é protestante e o que ele vê como uma diferença importante em relação aos seus vizinhos. No seu relato, a religião é uma marca próxima ao que ele mostra como seu sucesso: demarca seu sucesso mostrando o computador e dizendo que é o único do prédio que tem computador. Veste-se com camisa (a maioria dos homens usa camisetas) e faz questão de dizer que tem dois carros. Os seus bens são para ele a prova de que está tendo sucesso, o que atribui à sua postura como protestante.

Embora presente no dia da entrevista, a sua mulher não quis participar ou sequer tecer algum comentário. Ficou na cozinha, separada da sala por uma cortina clara, ouvindo o que falávamos e sem aparecer para me cumprimentar. Igor é o chefe desta família.

Além de seu relato de sucesso, Igor relatou um drama familiar. A sua filha fugiu de casa. Ele comenta o episódio com desgosto e uma fala repleta de expressões moralistas.

"A gente fica chateado, né, com o que acontece na nossa vida, né? Mas, é assim mesmo, né? A gente que fez. a escolha, escolher logicamente do nosso par. Eu escolhi a minha esposa. A minha esposa me escolheu a mim. Como também os pais dela também... Sei lá o que teve ali de escolher também quem era pra fazer convivência... Ela também teve a dela, né? Pra mim, não tem futuro. Pra mim não tem futuro. Porque se tivesse futuro...(...). 
Pesquisadora: O namorado dela trabalha?

Igor: Namorado nada. É macho mesmo. (Risos) Vamos falar a linguagem atual. Eu sou daquele tempinho lá detrás, sabe? Pra mim não faça a coisa errada aí. Você sabe muito bem. Antes, se você olhasse no meio de um multidão e você visse uma biscate assim, você percebia que era uma putona mesmo no meio de uma multidão. Você percebia. Hoje em dia você não percebe mais. Tá tudo murado. É diferente, né? Eu sou desse tempo. E tenho esse raciocínio comigo e não tenho como mudar, tá entendendo? Não tem esse negócio de modernismo. Pra mim esse negócio de modernismo é sem-vergonhice. É falta de caráter da pessoa. Acho que a pessoa que tem caráter não precisa ficar se mostrando que é gostosa. Ou o homem querendo mostrar que é o mais gostoso ou o melhor ou o matador ou sei lá o quê. Nada disso. Eu sou desse tipo. Sou meio isolado também. Qualquer hora você pode vir no meu apartamento que eu tô aqui em casa, se eu não estiver trabalhando. Não sou de ficar na rua batendo papo fiado. Pra mim, é tudo... Não gosto. Não gosto de falar da vida de ninguém. Mas, aquilo que for do meu alcance, eu falo também. Se for, que eu fale. Jamais eu vou falar mal. Se é pra falar de irmão, eu falo também. Goste de mim quem gostar. Sou cheio de amizade, ninguém - acredito eu - que ninguém vai falar muito mal de mim aí, se você for fazer uma pesquisa aí. Mas, eu não gosto. Não sei porque.

\section{(...)}

Eu fiz o cursinho básico de computação. Mas, o que eu aprendi, Graças a deus, vamos dizer assim, eu não tenho inveja de muitos que tão mexendo aí, não... Esqueci, claro. Também falta muito aprender. A gente nunca aprende tudo, né? A gente a cada dia que vai passando, a gente tá sempre aprendendo alguma coisa, né? Mas, eu sou evangélico. Não tenho nada contra a outra religião qualquer. Mas é aquela coisa, né? Cada um tem, vamos dizer assim...."

Igor nasceu em 1958 no interior de Pernambuco. Seus pais eram proprietários e Igor ajudava na criação do gado e no roçado. Veio a São Paulo com o irmão que trabalhava em uma construtora e foi morar com ele em alojamento da firma. Quebrou a 
perna num jogo de futebol e passou mais de um ano afastado do trabalho, internado num hospital. Quando retornou, estava disposto a abandonar o emprego, pois sentia-se cansado. Foi morar em uma pensão no Tatuapé e foi trabalhar numa indústria plástica. $\mathrm{Na}$ época do milagre brasileiro abundavam vagas de trabalho:

"Porque você passava numa firma não tinha como você... Sempre existia placa, entendeu? Sempre existia placa.(...) Se eu chegasse lá, batesse e falasse com o porteiro, ele ia rapidinho e já te mandava prum escritório lá, que já fazia uma ficha lá e já ficava trabalhabdo. Quantas vezes eu já... Pra você ter uma idéia, eu saí da Natel Plástico e entrei na... (inaudível) Pelton ${ }^{70}$. Saí de manhã e à tarde eu já tava empregado."

Saindo do ramo plástico, foi trabalhar no ramo de tecidos. Encontrou a esposa na terra de seus pais, que visitava todo ano. Conheceu-a quando eram crianças, namoraram por correspondência e casaram-se em São Paulo, fugidos, pois o pai dela era contra o casamento. Moraram em São Mateus, no Pró Morar. Em seguida na Vila Dalila, onde moraram sete anos, de aluguel. Compraram um apartamento de uma moradora na Cidade Tiradentes, sem pesquisar sobre a documentação. O real dono do apartamento apareceu cobrando o valor do apartamento e Igor deu a ele um terreno em Ilha Comprida, em troca da regularização junto à COHAB-SP, em 1994. Igor conta sobre a construção das garagens:

Pesquisadora: E você comprou essas garagens da mesma pessoa que...

Igor: Não. Quando eu entrei aqui, morando aqui, essas garagens aí... Bastante tempo, né. Não tinha muita garagem construída aí. Tinha poucas. Tinha bastante terreno aí. Então, quem quisesse construir e tivesse condições de aplicar pra fazer isso aí, né, podia fazer. Aí onde eu fui e (...) construí.

(...)

Pesquisadora: Mas, tem algum documento? O senhor tem algum documento da garagem?

${ }^{70}$ Os nomes são fictícios. 
Igor: Não. Eu não tenho documento porque ninguém tem documento da garagem. Todo mundo respeita onde é a garagem de fulano, de sicrano, ta entendendo. (...)”

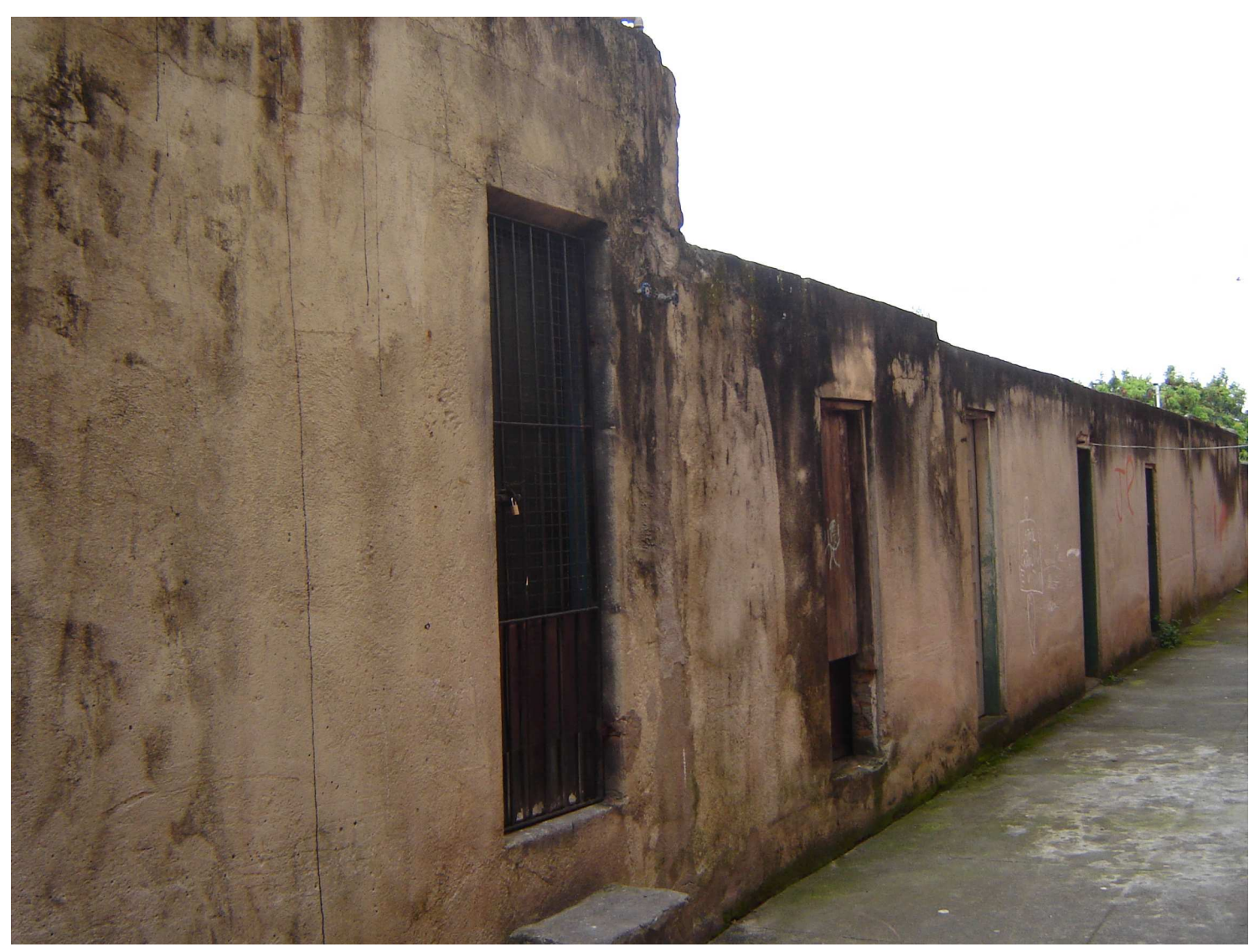

Corredor lateral do edifício, com as portas de entrada para as garagens construídas pelos moradores.

Para a COHAB-SP, as garagens inexistem. Não há plantas, não há registros de propriedade. Mas elas são amplamente construídas, utilizadas e comercializadas. Nelas são realizadas atividades comerciais, que tampouco poderiam acontecer no espaço da COHAB-SP. A despeito de não existirem no papel, elas são usadas para guardar os carros, ou para atividades comerciais, e negociadas pelos moradores como imóveis. São feitos contratos de compra e venda sem nenhum documento ou planta. A regulação destes espaços é inteiramente realizada dentro do espaço coletivo como extensão do espaço privado, mas fora da legislação pertinente. É uma apropriação dos moradores, que se auto-organizam em torno de algo que passa a ter valor para eles, e, embora tenha 
similaridade com o que existe de legal (são feitos contratos e a relação é mercantil), é uma negociação autônoma e própria. É uma expressão da medida do reconhecimento de um valor pertinente a todos, instituído no espaço coletivo. Como os demais valores do espaço coletivo, é uma mercadoria.

Igor trabalhou até 1996 como empregado e decidiu investir suas economias, o equivalente na época a três carros populares, em uma pizzaria disk-entrega na COHAB José Bonifácio. Entrou como sócio com o cunhado, mas este não investiu recursos. A pizzaria não foi para frente e Igor amargou o prejuízo. Entre as razões da derrocada, Igor enumera a dificuldade com funcionários e impostos e o fato de o ponto que ele comprou ser "queimado": antes funcionava uma pizzaria muito ruim.

Em 1997, Gérson já trabalhava com tapioca. Igor conversou com ele em busca de algum conhecimento com o assunto, como uma alternativa de geração de renda. Informado sobre o mercado de trabalho, Igor acredita que "emprego não existe mais".

Sua recuperação da situação da pizzaria se deu concomitante à sua entrada no mundo do protestantismo. Iniciou sua vida de crente pela Universal do Reino de Deus, seduzido pela busca do sucesso financeiro, mas logo aprofundou a fé e entrou na Congregação Cristã do Brasil, em busca de entendimento sobre a Bíblia.

Seu universo hoje gira em torno da produção da tapioca, da venda na feira e da Igreja. No prédio ele se colocou como uma espécie de gerente da tapioca. Organizou a destinação do lixo: as cascas de côco eram queimadas e exalavam uma fumaça preta. Ele conversou com Gérson. Sugeriu que dessem uma caixinha para o lixeiro. Ao mesmo tempo, fez a ligação da água nas garagens. Enquanto a água era coletiva isso provocava conflitos, pois pessoas "de fora" (de outros prédios) iam lavar o carro lá. A água individualizada foi vista por ele como um movimento positivo.

$\mathrm{Na}$ feira, a violência aparece. Assaltos e assassinatos em torno da venda das tapiocas. Para se assegurar de certa tranqüilidade, Igor, como os outros comerciantes, paga por segurança privada aos próprios policiais. 
Respeitado no prédio, Igor não concorda com a gestão do condomínio. Acha que pagam muito caro pela reforma e o trabalho não é executado. Discorda do valor do condomínio e da taxa da reforma. Admite que houve gestões melhores e gestões piores. Identifica a figura de Reinaldo, um bom síndico, que saiu do prédio. E de outro morador, que ele não chama pelo nome, na administração de quem houve roubo. Acredita que os problemas do condomínio são por falta de união. Numa ocasião, foi síndico por três dias, em 2001. Desistiu logo que um morador afirmou: "Olha mais um aí que vem roubar!". Ficou ofendido e resolveu abandonar a posição. Sua postura desde então é de não envolvimento, que ele justifica por meio da máxima: "o povo de Deus não se mistura."

No espaço coletivo, Igor é o homem de sucesso bastante respeitado. Assim como sua distinção social fica evidente, o distanciamento que os vizinhos mantém em relação a ele é evidente. Circula como um empreendedor liberal, ocupado demais para assumir a gestão do espaço coletivo.

\section{Viração em tempos difíceis: Macedo e Sueli}

Macedo e Sueli trabalham no prédio e são bastante conhecidos. Ele faz serviço de pedreiro na Tiradentes. Ela cuida de crianças. Acolhedores, gostaram de conversar e me convidaram a entrar desde a primeira visita, no apartamento simples e com aspecto de inacabado. $\mathrm{O}$ banheiro não tem porta, o piso está no cimento e a pintura deve ser a primeira e única que as paredes viram. Os vidros não são limpos, na cozinha há apenas uma estante e na sala, um móvel para a tevê e um sofá surrado. Um lençol separa o cômodo do quarto. O investimento no apartamento foi mínimo. Sueli não tem boa parte dos dentes. A filha parece querer uma saída daquele espaço familiar, e o caminho mais curto é o casamento. Macedo tem uma história de abandono na infância. Um trajeto triste, uma história de ausências, mas de muito trabalho, como eles contam. Excesso de trabalho, mas que não consolida conquistas, aparentemente.

Macedo nasceu no interior do Ceará e Sueli, no interior de Pernambuco. A primeira migração de Macedo foi para Fortaleza. Cedo perdeu o pai e foi morar numa fazenda, trabalhando como faz tudo. Adolescente foi para a capital, e decidiu tentar a vida em São Paulo. Sua trajetória não ficou muito clara (durante a entrevista estava 
acompanhado da mulher, que falou mais), mas foi possível saber que ele trabalhou em firmas com construção civil, atividade que mantém por conta própria sempre que "aparece serviço".

Sueli começou a trabalhar aos 14 anos, ainda em Pernambuco. Seu pai a pôs para trabalhar como empregada doméstica, para que ela pudesse comprar suas próprias coisas. Aos 16 anos veio a São Paulo morar com o tio e na mesma semana começou a trabalhar como empregada doméstica. Ela conta um episódio que ilustra a desolação de uma migrante recém chegada à cidade grande:

"Ai trabalhei lá sem... A segunda semana que eu fui, meu tio me deu só o dinheiro da passagem, só com o dinheiro da passagem, ai não sei como me atrapalhei acabei descendo no ponto errado, sem conhecer São Paulo, sem conhecer nada. Ai eu desci, quando eu vi não era um lugar conhecido, não era ali... Eu sei que tinha uma pracinha, né, e era ali mais ou menos parecido onde eu ia descer, mas não era, e eu não acertei a casa da mulher e fiquei com vergonha de pedir dinheiro para mim voltar, voltar para trás. Só que o dinheiro, na época não tinha esse cartão que é o bilhete único, e como eu era muito vergonhosa eu não pedia, fiquei com vergonha de pedir para os outros. Ai eu fiquei chorando, eu lembro que eu chorava, suba o ponto chorando, de um ponto pra outro, porque queria ir embora, mas não tinha como, com vergonha de pedir a condução, pedir pro motorista para eu ir embora e com vergonha de pedir a alguém do ponto o dinheiro de voltar."

O seu relato evidencia a cidade como o lugar do desconhecido, em que os recursos que se traz não são suficientes para elaborar uma cartografia simbólica e concreta que faça sentido. É por isso que ela não se sente à vontade para circular na cidade. A chegada é um momento de suspensão cognitiva, e muitas vezes a cidade intimida (como no relato, em que ela expressa vergonha).

Instalou-se numa favela, em um lugar que é nomeado pelos entrevistados de um modo geral como um lugar "perigoso": São Mateus. Começou a trabalhar numa confecção de roupas. Da faxina aprendeu a costurar e passou 13 anos trabalhando nesta 
firma. De Guarulhos foi morar com a tia na Cidade Tiradentes, no mesmo prédio. Ela estava então grávida da sua filha. Conheceu Macedo na Cidade Tiradentes, quando sua filha acabara de nascer. Entrou no apartamento em que está pagando aluguel, mas ficou sabendo que a situação era irregular. Em negociação com a COHAB-SP, tornou-se mutuaria, na época do governo Erundina:

Sueli: Ai depois, o dono aqui, como ele tinha esse e tinha mais outro, na época não podia alugar, né? Porque na época tinha fiscal da COHAB, então eles viram eu aqui, pediram meus documentos, né, eи peguei e apresentei os documentos porque eles pediram o nome do dono e eu não sabia o nome do dono, que isso aqui já era de vários donos, já sou a terceira, né, e a única, ai eu peguei e apresentei meus documentos, ai nisso eu fui na COHAB $e$ a COHAB não deixou mais pagar a prestação, a prestação não, quer dizer, o aluguel, porque não era para alugar, ai eu passei a pagar o carnê na COHAB.

Pesquisadora: E não pagou mais o aluguel?

Sueli: E não paguei mais o aluguel.

Pesquisadora: E o proprietário não veio falar com você?

Sueli: Não, não, a COHAB, que na época que eu fui na COHAB, a COHAB falou para mim que ele, que ele não era o dono no registro, que o dono é aquela pessoal que está com os papéis lá na COHAB, na pasta lá, ai como tinham vários apartamentos, que ele já comprou negociando, né, então a COHAB tomou, porque não podia negociar os apartamentos da COHAB na época, que era para aquelas pessoas que precisavam. Hoje não, hoje eles estão fazendo compra, vendem, alugam, mas antes não podia alugar...

Foi demitida da empresa pois morava muito longe e, na época (início dos anos 1990) as greves de ônibus eram freqüentes, o que fazia com que ela se atrasasse para o serviço.

Este fato ilumina a forma como a configuração urbana interfere diretamente nas trajetórias dos indivíduos. O serviço de transporte é dificultoso e morar em bairros da 
periferia torna-se critério de seleção em entrevistas de emprego, seja pelo estigma ${ }^{71}$, seja pelo cálculo do valor do transporte que o empresário faz (no caso dos contratos formais), seja pela previsão de que o funcionário, ao morar longe, não respeitará o horário de trabalho. Eventualmente, são situações que se misturam no imaginário do empregador.

Sueli investiu a indenização do fundo de garantia num terreno em São Mateus, mas percebeu que o local era irregular e sentiu-se ameaçada pela presença freqüente de bandidos. Achou melhor "deixar pra lá".

Na Cidade Tiradentes começou a fazer "bicos". Comprou duas máquinas de costura e, com uma amiga, passou a "pegar serviço" de costura. Inúmeras confecções usam mão de obra contratada por serviço, e as costureiras trabalham em suas casas, recebendo por peça, em geral valores irrisórios face ao valor de comercialização da peça na loja, no shopping center. Sueli e amiga não deram conta, pois era "muito serviço". Não conseguiram mais pessoas para costurar pois as costureiras da região foram trabalhar na Acetel, cooperativa da região (cooperativa de mão de obra de costureiras, fundada e mantida por um personagem ligado ao PCdoB, que mantém um contrato com o governo federal para a produção dos artigos esportivos das equipes brasileiras e da bandeira brasileira ${ }^{72}$ ). O "bico" que restou é cuidar de crianças, atividade pouco lucrativa e que a mantém ocupada sem muito entusiasmo.

Como já citado, o início da pesquisa coincidiu com uma ampla reforma no prédio - a troca dos pisos das escadarias e áreas comuns, a pintura externa, a construção de um muro e de uma nova entrada. Uma obra orçada em $\mathrm{R} \$ 24.000,00$ a ser paga em dois anos pelos moradores, representando um total de $\mathrm{R} \$ 15,00$ de acréscimo ao valor do condomínio. Ressalte-se que nossa primeira entrevistada foi a síndica do prédio, e as primeiras pessoas contatadas, relacionadas a ela diretamente. Foi, contudo, surpreendente, entrevistar Macedo, que ressente-se de não ter sido chamado para executar a obra:

\footnotetext{
${ }^{71}$ O estigma de morar em Cidade Tiradentes tem sido estudado por D’Andrea (2008).

${ }^{72}$ Conforme Rizek \& Georges (2008).
} 
"Isso aqui eles fazem daquele jeitão, sabe. Ela [a síndica] disse pra mim.

Inclusive eu tinha dito antes, eu disse, olha, contrata, chama três empreiteiras, faz uma licitação, tipo de uma prefeitura, que vai três empreiteiras e elas pegam a melhor, a mais prática e a mais barata, geralmente é isso. Aí eu disse, chama três empreiteiras, pessoas que têm responsabilidade, que entendem da área, aí eles fazem o orçamento deles. Você me mostra os três orçamentos, se der eu cubro os orçamentos e eu mesmo faço. Mas, nada disso foi feito. Por que?... Porque eu não sei. Não sei e sei, né, porque eles sempre trabalham, a gente não pode provar, mas sempre eles trabalham com caixa dois, isso daí não tem jeito. E o nosso país é isso aí.

Pergunta: Mas, você acha que então, quem contratou o serviço pode estar recebendo por fora?

Resposta: É, às vezes acontece, né.

$$
(\ldots)
$$

Porque o serviço não ia ficar pior comigo do que com o pessoal de fora..

Macedo, forte e incisivo, foi minoria na Assembléia dos moradores que debateu a continuidade da obra. Na ocasião, 24 moradores votaram acerca da continuidade ou não das obras, sendo 16 a favor e 8 contra.

O ressentimento de Macedo está na fala e na postura. Sueli não é diferente. Entre suas atividades está a de "olhar" crianças cujos pais trabalham. Numa ocasião estava por lá quando duas crianças estavam sendo olhadas. A expressão é certa. Cuidar de crianças requer atenção, empenho e disposição que não estão na equação de olhar. 
Macedo e Sueli são outsiders no espaço coletivo. ${ }^{73}$ São vistos como aqueles que devem ser excluídos e que se tolera, mas cujo lugar não é ali. Em sua encenação social, eles absorvem estes papéis e reiteram sua posição. ${ }^{74}$ Sua encenação não é capaz de articular as atribuições coletivas que dariam credibilidade à sua posição.

\section{O caminho de saída da Cidade Tiradentes}

O irmão de Macedo e sua esposa Fátima vivem também no mesmo prédio que Sueli e Macedo. Ribeiro, irmão de Macedo, morou também em Fortaleza, onde se casou, e onde aprendeu a profissão de eletricista. Trabalhou muitos anos na empresa de abastecimento de energia elétrica do Ceará. Sofreu um acidente no início dos anos 1980 e ficou dois anos afastado, quando então decidiu vir a São Paulo. Em São Paulo foi morar na Penha, trouxe a família e continuou trabalhando como eletricista predial. Mudava de emprego mas, até os anos 1990, não ficava desempregado. Sua ocupação sempre foi irregular pois trabalhava em empresas médias e pequenas, que demitem quando não têm empreitas contratadas. Continua trabalhando na empresa de um amigo em que foi demitido em 1995 no sistema de "bico" (sem contrato de trabalho), eventualmente, em média duas semanas no mês.

Ribeiro e Lúcia são opositores da gestão de Ilda. Em sua fala, questionaram a reforma desde sua concepção. No entendimento de Ribeiro, eletricista e encanador, toda a parte do esgoto do prédio deveria ser reformada para afastar os ratos. Mas o projeto contratado não prevê isso. Além disso, o serviço está atrasado. Lúcia foi tesoureira do prédio por três meses, quando teve o entendimento de que o valor do condomínio deveria ser depositado em uma conta corrente para as melhorias, mas isso não foi aceito pela então síndica.

A família de Ribeiro e Lucia se colocaria como uma alternativa moral para a gestão do condomínio, mas efetivamente eles não buscam o apoio dos demais, talvez

\footnotetext{
${ }^{73}$ Elias (2000).

${ }^{74}$ Goffman (2006).
} 
por excesso de escrúpulos em relação aos benefícios que a posição poderia trazer para seus membros (como para Macedo que viria a se ocupar das reformas, por exemplo.) Talvez porque o plano seja sair dali, como de fato fizeram alguns meses depois.

Ribeiro e Lucia têm quatro filhos, dois homens e duas mulheres. As mulheres são casadas e vivem em Arthur Alvim. Um dos filhos é eletricista como o pai e o filho mais velho estava prestes a começar o curso de sociologia na Fundação Escola de Sociologia e Política. Filiado ao partido comunista, antagoniza com a síndica e aparentemente, com toda a realidade à sua volta. Tem um histórico de alcoolismo e talvez de envolvimento com drogas que não cheguei a conhecer, apenas ouvi boatos. Estes boatos são muito elucidativos de uma forma de vê-lo. Personagem anti-heróico, o menino, antagonista frontal da síndica, não é levado muito a sério, nem pela família nem pelos moradores. As irmãs, casadas, já saíram da Cidade Tiradentes e querem levar os pais. O projeto da família é o projeto de ascensão que significa sair de Cidade Tiradentes, diverso do projeto de ascensão e emancipação dentro da Cidade Tiradentes e do próprio prédio. Heitor, o filho do casal, coloca-se no espaço coletivo como um

antagonista, mas não consegue apoio à sua postura. Uma oposição estabelecida demanda reconhecimento do potencial de liderança, e escuta. No lugar da escuta, Heitor tem pressa e inquietação. Seu pai, ao contrário, é figura querida e circula no espaço coletivo quase como um conselheiro, a quem se pode ouvir. Mantém-se no registro da vida familiar, sem colocar-se efetivamente nas questões condominiais.

\section{Tornar-se policial na Cidade Tiradentes: um risco.}

Da geração jovem de famílias no prédio conversei com Túlio que, em pouco tempo trabalhando, comprou um carro, um apartamento, e reformou o apartamento. Andava desempregado e seu projeto é um posto na polícia militar. Túlio sabe que quando passar no concurso para a polícia militar vai precisar sair da Tiradentes, mesmo porque ele cresceu com outros jovens que hoje estão no crime organizado. Se ele for policial na Cidade Tiradentes, seus amigos que hoje estão no "movimento" (como são chamados quem participa do crime organizado) poderão sentir-se acuados e ele estará em risco. Seja por tolerância aos seus amigos, seja por temor deles, seu destino é sair da 
Cidade Tiradentes para agir como policial. Caso a carreira policial não vingue, ele opta por ficar na Cidade Tiradentes. A Cidade Tiradentes é para ele um local positivo e dinâmico. Seus amigos estão por perto, eles passeiam bastante pela própria Cidade Tiradentes e ali ele seu próprio apartamento.

Seu local no espaço coletivo confunde-se com seu papel como filho. Seus pais moram em um outro apartamento, outra irmã sua mora num terceiro apartamento. Eles comem juntos, vivem uma vida de família extensa em um prédio. ${ }^{75} \mathrm{O}$ momento no ciclo de vida e os investimentos não o fazem considerar como importante a gestão das questões coletivas.

\section{Migração e trabalho fabril.}

A trajetória de Carla conta a história de migração a caminho da cidade nos anos $1970 .^{76}$ História de muito trabalho, de conhecer o marido no ambiente da fábrica, de montar a vida juntos, da rede de apoio familiar (sogra, irmãos). Carla criou os filhos na Cidade Tiradentes e separou-se do marido. Ela não fala da sua separação. Mostra-se como uma chefe de família e é respeitada como tal no espaço coletivo. Embora apóie a síndica, tem suas ressalvas. É alguém que eventualmente participaria de uma gestão condominial, mas, por comodidade, prefere não se envolver. O projeto da filha, casada, é um apartamento em que possa levar móveis maiores, uma expressão do seu desejo de espaço.

\section{A cooperativa de Mão de Obra}

Valquíria ilumina o trabalho na cooperativa (que na realidade é uma cooperativa de mão de obra), a Acetel - Associação de Mutuários e Moradores do Conjunto Santa

\footnotetext{
75 Entre os 60 apartamentos, 14 estavam ocupados por famílias extensas de moradores. O edifício foi ocupado por famílias extensas e relacionais, todo o tempo solidárias numa esfera de dependências, dentre as quais os cuidados com as crianças e a comensalidade.

${ }^{76}$ Durhram (1984).
} 
Etelvina. Sua trajetória revela as ambigüidades da situação. Na cooperativa ela recebe um salário superior ao que receberia em uma fábrica no Brás, por exemplo. No entanto, é uma cooperativada-assalariada. Esta cooperativa vem sendo estudada por Rizek \& Georges (2008). Mantém contrato com o Ministério dos Esportes e o presidente Lula já esteve visitando o espaço que abriga também uma grande associação de moradores. Nascida na luta contra as elevações dos valores das prestações da COHAB-SP a associação tornou-se um lucrativo negócio para seus diretor, que criaram a cooperativa de mão-de-obra.

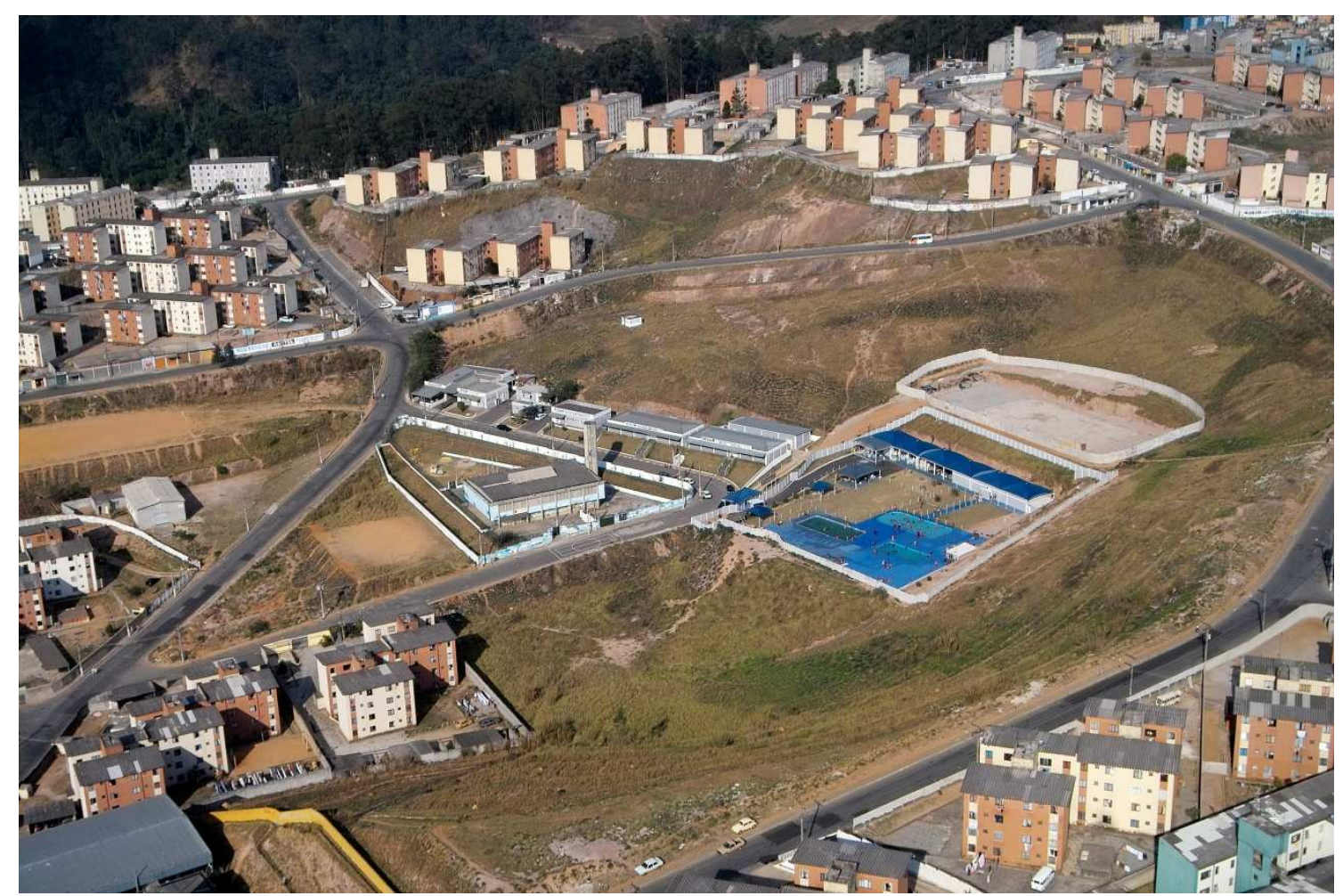

Foto: Jorge Hirata. Pesquisa Mobilidades urbanas e trajetórias sociais: trabalho, moradia e mobilidade cotidiana.Coordenação: Vera Telles e Robert Cabanes.

Como pontuam as autoras a definição da Acetel como associação/ ong/ cooperativa ou empresa não é uma questão meramente de denominação “já que poderia desenhar expectativas, práticas, formas de ação das direções assim como de seus participantes/ membros/ trabalhadores/ filiados”. Rizek \& Georges (2008, p. 1).

Valquíria, como outras mulheres que trabalham na Acetel, trabalham quando o contrato da organização é assinado com alguma empresa ou com o governo. Significa que ficam boa parte do tempo sem trabalho. Na época da produção intensa, o trabalho 
excede a jornada permitida por lei. A remuneração é por peça. Embora seja cooperativada, ela desconhece o estatuto da cooperativa e sua inserção é como a de uma assalariada sem carteira assinada: na época em que o contrato está vigente trabalha todos os dias. O sistema de trabalho é intenso e a pressão da supervisão de produção é grande. Não são permitidas conversas e o horário para o uso do banheiro é restrito.

Para Valquíria, no entanto, a experiência é vista positivamente, pois para ela a Acetel confunde-se à figura do presidente Lula, por quem ela nutre grande admiração (exibe a foto que tirou com ele), e, no limite, sua remuneração é maior do que quando ela trabalhou em empresas de costura no Brás. O trabalho não é visto como precarizado, comparado à outras experiências de trabalho igualmente precárizadas. Sua geração conheceu a subcontratação dos serviços de costura. A inserção como cooperativada é apenas um meio como outro qualquer de acessar o trabalho e renda, e não uma forma de produção que poderia lhe abrir a possibilidade de organizar a sua forma de trabalhar. São ambigüidades que estão presentes nos novos vínculos de trabalho, formas de apropriação da legislação como modo de precarização do vínculo do emprego, via de regra favorecendo o empregador, que muitas vezes se confunde com o "presidente da associação" ou o "diretor da cooperativa."

São ambigüidades presentes em relações diversas com o mundo público na contemporaneidade, como também ilumina a trajetória de Paula.

\section{Trabalho em ONG na periferia: militância ou emprego?}

A trajetória de Paula, trabalhadora em uma organização não governamental, também ilumina as ambigüidades do mercado de trabalho e da política no mundo pós fordista. Sua trajetória é sofrida e pode ser lida na chave da busca por autonomia. Jovem, recém-separada e com um filho pequeno, tem dificuldades de se manter distante do ex-marido, de quem depende emocionalmente. Paula, talvez por sua infância repleta de episódios de violência doméstica sofrida tendo como algoz o padrasto, não consegue 
romper com o ex-marido. Sua relação com o trabalho revela laços privados no que se pretende uma prática associativa e democrática. Um dos diretores da organização que ela trabalha se orgulha de dizer que a ong se distingue pela busca de democratização das relações com os atendidos. Todos os diretores e a presidente da organização são da mesma família. A organização mantém convênios com a prefeitura de São Paulo e atende crianças em horário complementar ao da escola, além de manter projetos de acompanhamento social e jurídico de famílias de adolescentes em conflitos com a lei. Acompanhei uma assembléia de alunos, que conhecem as normas da organização e também as contas. Na época da entrevista, Paula era responsável pela limpeza na organização. Os alunos, numa dessas assembléias, solicitaram-na como educadora, vaga em aberto na ocasião. Paula, que foi chamada para trabalhar lá depois de um breve trabalho junto ao partido, disse-me que a presidente da organização chamaria sua sobrinha para a vaga, desconsiderando o pedido dos alunos. Por mais horizontalidade que se busca, a estrutura da ong é vertical e as decisões são tomadas pela esfera que preside, e não pelos atendidos.

Talvez seja possível ler nesta relação entre a ONG e Paula, a contratada, uma reprodução de um vínculo compatível à lógica gestionária de que fala Paoli (2007). A ONG realiza um trabalho em que a democratização das relações não é uma experimentação da política, mas é uma técnica de gestão, e, como tal, a força do discurso do poder.

Paula não é exatamente militante. Sua presença no partido era em troca de salário, assim como seu trabalho na organização é profissional. Nova no prédio, sua relação com o apartamento é afetiva e é onde estão seus dramas afetivos. Ela não busca se envolver na gestão do condomínio. Sua presença no espaço coletivo é da carência afetiva, e assim ela é vista por seus vizinhos.

\section{Ambigüidade da situação de moradia na Cidade Tiradentes: retrocesso de condição de vida com o acesso à casa própria.}


Gabriela e Wilson formam um jovem casal recém moradores de Cidade Tiradentes. Pais de quatro filhos, entre 13 e 4 anos de idade, moravam na V. Maria, berço da família de Gabriela, e para eles o apartamento em Cidade Tiradentes foi uma opção para sair do aluguel. Wilson é um rapaz jovem e ativo. Ao longo de sua vida profissional desenvolveu a profissão de sapateiro, que aprendeu com o pai e atualmente é segurança e instalador de equipamentos eletrônicos. Gabriela saiu do serviço doméstico para investir em uma carreira no ramo de confecção. Apesar das restrições financeiras, são animados e dividem seu tempo livre entre a igreja evangélica e as rodas de samba e pagode em que Wilson toca cavaquinho. Eles contaram um episódio dramático da doença de um dos filhos que evidencia as relações solidárias entre os moradores da Cidade Tiradentes. $\mathrm{O}$ menino teve um ataque epilético num domingo à noite e todos os moradores do prédio saíram para acudir. Um dos moradores emprestou o carro e levaram-no ao hospital em Cidade Tiradentes. Não havia médicos nem plantão de atendimento no gigantesco hospital inaugurado recentemente. Felizmente no Posto de Saúde o menino foi medicado e se recuperou de uma parada cardíaca.

Para Gabriela e Wilson morar no prédio significa, por um lado, um retrocesso na vida. Da Vila Maria, bairro próximo ao centro, à Cidade Tiradentes a distância é considerável. Com o olhar nesse movimento da vida da família entende-se que eles olhem os vizinhos com distanciamento, classificando-os como acomodados, ou seja, aqueles que têm o apartamento garantido (a inadimplência não implica em expulsão), e portanto não são muito voltados ao trabalho. Por outro lado, os vizinhos são vistos como solidários, pois "olham" seus filhos (cuidam das crianças) quando os pais não estão por perto. Esta presença dos vizinhos terá a sua importância na educação das crianças. Nesta ambigüidade, fazem planos de reformar o apartamento ao mesmo tempo em que sonham voltar para a Vila Maria. Seus empregos são instáveis e pouco duradouros, ao sabor das circunstâncias do mercado (contratos das empregadoras). Contudo, são dinâmicos e estão sempre realizando alguma atividade produtiva. Sua presença no espaço coletivo é a de uma família jovem que sonha junto; por isso mesmo, sua energia não se voltará neste momento para as questões do condomínio. 


\section{Experiência em favela, experiência de habitação provisória na Cidade Tiradentes}

Por intermédio do jovem casal conheci D. Nair. D. Nair é uma senhora com uma longa e difícil trajetória de vida que está no prédio numa situação provisória. Nasceu no interior do Paraná e casou-se para fugir das ameaças de abuso sexual do padrasto. Rompeu definitivamente com a mãe e sua família passou a ser a família do marido. Perdeu um filho de oito meses, morto de tuberculose. Com sua filha mais velha, decidiu com o marido tentar a vida em São Paulo.

"A minha primeira impressão foi feia, cheguei na Rodoviária Velha. Tinha o endereço na mão. A minha sorte era que tinha um bom dinheiro, porque tinha plantado e tinha dado bastante." (...)

"A gente imaginava que era o lugar de ganhar dinheiro, de muita gente bonita. Não era bem assim."

Foi morar com o marido num cômodo na Capela do Socorro, zona sul de São Paulo. O marido trabalhava numa metalúrgica. Em São Paulo nasceu sua segunda filha. O marido a abandonou para viver com outra mulher, no mesmo bairro. No entanto permaneceram casados e vivendo como amantes. D. Nair trabalhou numa metalúrgica de lacre de medicamento e como empregada doméstica. Cansada de sua situação com o marido, foi para o Paraná na casa dos sogros. Viveu e trabalhou no Paraná numa empresa de ônibus durante dois anos. Voltou a São Paulo. Foi trabalhar na casa de campo da apresentadora de TV Hebe Camargo, no Horto Florestal. Engravidou do marido e quando a criança nasceu a apresentadora convidou-a para trabalhar no Rio de Janeiro. Com medo de que a apresentadora roubasse o seu filho ${ }^{77}$, não foi.

D. Nair passou então a trabalhar numa empresa contratada de faxina no Hospital das Clínicas. Fez um acordo para ser demitida e recontratada para, com o fundo de garantia, comprar um barraco na Capela do Socorro, por R\$ 800,00. Lá, teve um caso e

\footnotetext{
${ }^{77}$ Este episódio inverossímil é contado com credibilidade, o que revela a força do fantástico na re-leitura da própria experiência, que pode ser mais evidente em pessoas como D. Nair, para quem o vínculo com a realidade parece tênue.
} 
um filho deste caso. Ficou 7 anos no HC e 14 anos na Capela do Socorro. Teve ainda um outro filho, de um terceiro relacionamento. Tentou a guarda das suas filhas, que moravam com o marido e com a amante, mas o juiz deu ganho de causa a eles. Quando o marido morreu se organizou para reivindicar a pensão. Teve uma menina, de outro namorado, mas decidiu que não ia mais se casar. Um conhecido ofereceu o apartamento em Cidade Tiradentes para ela cuidar, e é por isto que estava há alguns meses no prédio, com os três filhos mais jovens. Não trabalha, recebe pensão. Está tentando vender a casa na Capela do Socorro para ir morar definitivamente em Cidade Tiradentes.

D. Nair ilumina uma relação com o mundo público que passa pela mediação da família e suas vicissitudes. Nesta relação, o mundo do trabalho lê-se na chave do mundo da necessidade. Sua relação conflituosa com o marido redundou em um conflito permanente com as filhas e num projeto familiar bastante vinculado ao sabor das oportunidades da vida. Sua presença no espaço coletivo é um pouco nebulosa, como moradora de circunstância, ela não se envolve nas questões do condomínio. Sua experiência na favela lhe confere um sentido de sociabilidade solidária e expandida, cuja adaptação ao universo do prédio ainda não havia sido inteiramente realizada.

\section{A força da religião evangélica}

Joana e Milton mantêm um casamento cujo maior conflito é o apartamento. Ela quer morar numa casa (dos pais dela), ele não aceita. Ela, contudo, não aceita separar-se por isso. Gosta do marido e ademais não quer perder os privilégios na igreja. Para eles, abraçar o protestantismo significa ao mesmo tempo distanciar-se dos vizinhos, e distanciar-se das questões coletivas. Milton disse-me que os protestantes devem se afastar "do mal e da aparência do mal".

Milton é protético e faz um curso de técnico de segurança no trabalho. Ele fez observações interessantes sobre a gestão do espaço coletivo. Em sua visão de técnico de segurança, ele sugeriu durante a entrevista algumas medidas que ampliaria a segurança do prédio. Questionado sobre o motivo pelo qual ele não sugere estas medidas aos vizinhos, ele diz que sua condição de protestante o afasta da gestão do coletivo. 
De forma muito clara, a dinâmica familiar está organizada em torno de relações que privilegiam o espaço privado e suas conexões com o espaço público numa ordem simbólica que valoriza o espaço privado em detração de uma esfera coletiva, que é vista como "aparência do mal".

De uma forma geral, os comentários, contra ou a favor da síndica criam pontos de vista a respeito de como deve ser o espaço coletivo. Em torno disso um assunto é pautado nas conversas, e se coloca em latência. Este espaço coletivo é atravessado por conflitos, o que é evidenciado pelas disputas em torno do tipo de música e do volume. $\mathrm{O}$ desejo de distinguir-se dos demais está em potência, e está nas falas dos moradores quando eles dizem que os outros são bagunceiros e incapazes de união. Uma espécie de frustração está nessa fala, que demonstra o próprio desejo de avivar esta coletividade, como no caso de Macedo.

Seja pelo investimento ser estritamente privado (D. Vera), seja por opção justificada por uma visão de mundo (Milton e Joana), seja por inexperiência (Sueli e Macedo, ou Valquíria), os moradores delegam a tarefa da gestão do espaço coletivo à síndica. Há um entendimento se formando em relação ao que é coletivo e das possibilidades de consolidação desse espaço para alguns (Ribeiro e Lúcia), e a possibilidade resta latente. Ocorre também uma distinção entre os tempos privados e o espaço coletivo (o caso de Paula ou de Túlio), ou do próprio tempo coletivo, no caso dos moradores que se mudaram recentemente (Gabriela e Wilson ou D. Nair).

O espaço coletivo está em experimentação, mas estamos longe de um lugar de idealização do que se possa chamar de comunidade. Os laços entre as famílias são tensos, feitos de disputas simbólicas e de desejo de afastamento. Afastamento que muitas famílias efetivamente conseguem quando mudam dali. O fantasma da violência está presente, e organiza os julgamentos e os discursos que se transmitem entre gerações. Este julgamento, ao mesmo tempo em que é bastante profundo em alguns casos (como no caso dos protestantes), pode em algum momento ser flexibilizado dependendo da circunstância.

No espaço coletivo a situação social se coloca e diante dele os indivíduos mobilizam seu conhecimento de si para produzir seus discursos. Cada entrevista é uma 
situação que pode ser entendida até como cênica ${ }^{78}$, em que os personagens nos colocam pontos de vista e suas fundamentações. As fundamentações estão na relação com o mundo do trabalho, com acertos e fracassos sociais, que são transpostas para um espaço - também cênico - do coletivo. Neste coletivo encenam-se os caminhos e as interdições para uma realização.

A reforma pode ser entendida nessa chave. Como uma ação coletiva, ela se põe em marcha a partir de uma iniciativa (de Ilda). As alternativas para sua consecução são colocadas ao julgamento do coletivo. Apresentam-se propostas, como a de Macedo e a de Ilda. A aceitação da proposta de Ilda em detrimento daquela de Macedo revela que os moradores entendem os atributos de Ilda mais críveis do que os de Macedo. O olhar para Ilda, mesmo quando crítico, reconhece seus laços no bairro e isto é visto como elementos de poder que se devem considerar. Ao contrário, Macedo não conta senão com sua razão, que não chega a convencer os outros moradores. Nesta cena, houvessem se posicionado Ribeiro e Lúcia, talvez a força da oposição fosse maior. Eles, no entanto, permaneceram na possibilidade do não-envolvimento baseada no desejo de sair do prédio. A situação se desenrolou e os moradores todos tiveram que arcar com o prejuízo de sua decisão (ou indecisão): o atraso nas obras, que dão margem às suspeitas de roubo e corrupção. A fronteira entre ilegalidade e legalidade perpassa todo o cotidiano dos moradores, e não seria de se admirar um novo calote. Diante destas pequenas frustrações muitas famílias se voltam para o universo familiar, de cálculo mais simples. A pauta do espaço coletivo, por seu turno, é a pauta da mercadoria. O tempo todo as relações são mediadas pelo valor monetário: as contas de condomínio, as taxas de serviços, as taxas de reforma. É como se, no âmbito do coletivo, ao largo das relações de cordialidade do dia-a-dia, o que interpelasse a vida fosse da ordem do que se pode pagar. Duas gerações basicamente convivem no prédio, e uma delas guarda a vivência da ditadura militar. A outra cresceu com a referencia de um mundo público mediada pelo consumo. As trajetórias individuais reforçam lugares nas cenas coletivas em que os preconceitos se cristalizam, e os assuntos são pautados. O mundo público está presente, pois os indivíduos se relacionam com o mundo do trabalho, trazem olhares de suas trajetórias e das vivências de sociabilidade para além dos muros do prédio. Na

\footnotetext{
${ }^{78}$ Em referência à abordagem de Goffman (2007) ao social.
} 
experiência de encontros nas escadarias e relatos a uma pesquisadora, no entanto, este mundo público parece ser encolhido nas possibilidades do que se considera que seja a experiência de vizinhança e do entendimento e envolvimento com o espaço coletivo. 


\section{Considerações Finais}

A experiência descrita nesta dissertação, pautada pela pesquisa no campo e pelo olhar analítico de outros pesquisadores, buscou refletir formas de ocupação urbana e suas reverberações em trajetórias individuais. Ao mesmo tempo, recortou um ambiente em que o olhar estático para um outro, próximo do ponto de vista social e espacial, pudesse dizer de visões de mundo e de compreensões de práticas coletivas. Existirão práticas coletivas para além de sentimentos de identidade?

O fenômeno da identificação é situacional e político. No caso da vida cotidiana, da relação com o vizinho, que deve ser acima de tudo tolerado, existe identificação? Aqui também a identidade é circunstancial, e informada pelo modo como se vê o mundo e como se reflete. As práticas coletivas, no entanto, evidenciam tensões. Evidenciam a restrição da iniciativa, que não é prerrogativa de todos, mas daqueles que são investidos coletivamente desta possibilidade, e também evidenciam erros de julgamento (confiança depositada que foi frustrada). Isso não quer dizer da fragilidade dos envolvidos, mas do modo como a experiência coletiva é construída, com base em olhares, rumores, construções de opiniões, discursos, movimentos de apoio e boicote. Estes movimentos não estão fora do mundo público, da experiência urbana, do mundo do trabalho e da vivência da cidade, mas estão por eles mediados. As mediações que estão no mundo público estão no espaço coletivo. A relação com o trabalho na cidade é mediada pela mercadoria; e a relação com o vizinho é também mediada pela mercadoria.

Se não há consenso em torno da identidade num espaço coletivo, como construílo socialmente, para uma vivência mais libertária da cidade e da experiência do trabalho? A frase que nasce do horizonte da utopia, continua estimulando a atividade da pesquisa e da crítica. Não apenas a vida no edifício foi objeto desta pesquisa, mas o entendimento de que as políticas públicas têm desdobramentos. Por um lado, e mais evidente, as políticas configuram espacialidades. Por outro lado, elas atuam diariamente no cotidiano, por meio dos serviços públicos, da experiência nas escolas, e nas relações 
com a moradia. A política pública pode ser fiscalizatória e coercitiva, e isto tem implicações para a vida cotidiana, como no episódio relatado por uma síndica. As políticas mais macro, cujos efeitos não sentimos concretamente, podem ter implicações, nos preços, no que se constitui como alternativas de trabalho. E estas implicações muitas vezes não estão claras nos discursos oficiais e nem nos propósitos anunciados de nenhuma política. É por isto que a atividade de pesquisa ganha sentido e pode contribuir para a reflexão, seja de quem está envolvido diretamente na atividade de elaboração ou condução das políticas, seja quem está envolvido diretamente nas atividades de oposição ao estabelecido. Se esta dissertação puder contribuir com estas reflexões, seu objetivo está cumprido. 


\section{Bibliografia}

ADORNO, Theodor. Dialética do Esclarecimento. Rio de Janeiro: Jorge Zahar Editores, 1994.

AGAMBEN, Giorgio. Estado de Exceção. São Paulo: Editora Boitempo, 2004.

ALVES, Eliane e TELLES, Vera. Territórios em disputa: a produção do espaço em ato. In TELlES, Vera da Silva \& Cabanes, Robert. (orgs.) Nas tramas da cidade. Trajetórias Urbanas e seus Territórios. São Paulo: Humanitas, 2006.

ANTUNES, Ricardo. Os sentidos do trabalho: ensaio sobre a afirmação e a negação do trabalho. São Paulo: Boitempo Editorial, 1999.

ARENDT, Hannah. A condição humana. $10^{\mathrm{a}}$ edição. Rio de Janeiro: Forense Universitária, 2008.

ARRETCHE, Marta. Intervenção do Estado e setor privado: o modelo brasileiro de política habitacional. Espaço e Debates, n³1, 1990.

BENJAMIN, Walter. Obras Escolhidas - Volume 1. Magia e Técnica, Arte e Política. São Paulo: Editora Brasiliense, 1996.

BOSI, Ecléa. O tempo vivo da memória. Ensaios de psicologia social. São Paulo: Ateliê Editorial, 2003.

BONDUKI, Nabil. Origens da Habitação Social no Brasil. Arquitetura Moderna, Lei do Inquilinato e Difusão da casa própria. São Paulo: Estação Liberdade, 2004.

BOLAFFI, Gabriel. Habitação e urbanismo, o problema e o falso problema. in MARICATO, Ermínia (org). A produção capitalista da casa (e da cidade) no Brasil 
industrial. São Paulo: Editora Alfa-Ômega, 1982.

BOURDIEU, Pierre. A ilusão biográfica. (anexo de: Por uma ciência das obras. In Razões práticas. Campinas: Papirus, 1996

BOURDIEU, Pierre. O poder simbólico. Rio de Janeiro: Bertrand Brasil, 2004.

CABANES, Robert. Espaço privado e espaço público: o jogo de suas relações. In Telles,Vera e Cabanes, Robert. Nas tramas da cidade: trajetórias urbanas e seus territórios. São Paulo: Ass. Editorial Humanitas, 2006.

CABANES, Robert \& GEORGES, Isabel. Savoir d'experience, savoirs sociaux: le rapport entre origins et valeurs selon le genre. São Paulo, 2007. mimeo.

CALDEIRA, Teresa. Cidade dos Muros. Crime, segregação e cidadania em São Paulo. São Paulo: Edusp, 2000.

CARVALHO, Caio Santo Amore de. Lupa e Telescópio: mutirão em foco. São Paulo anos 90 e atualidade. Tese de doutorado. FAU-USP, 2004.

CASTELLS, M. A questão urbana. Rio de Janeiro: Paz e Terra, 1983.

CHAUVRÉ, Christiane et FONTAINE, Olivier. Le vocabulaire de Bourdieu. Paris: Elipses, 2003.

CONSTANTINO, Carlos Adriano Santos. A COHAB-SP e uma nova política habitacional: o período 2001-2004. Dissertação de Mestrado. FAU- USP, 2007.

D’Andrea, Tiarajú. Distâncias geográficas e acercamentos humanos. En publicacion: Divercidade, no. 16. Conjuntos Habitacionais. CEBRAP, Centro Brasileiro de Analise e Planejamento: Brasil. Janeiro-Março. 2008

DURHRAM, Eunice. A caminho da cidade. São Paulo: Ed. Perspectiva, 1984. 
ELIAS, Norbert. Os Estabelecidos e os Outsiders. Rio de Janeiro: Jorge Zahar, 2000.

FELDMAN, Sara. Planejamento e Zoneamento em São Paulo 1947-1972. São Paulo: Fapesp-Edusp, 2005.

FELTRAN, G. S. . A fronteira do direito: política e violência na periferia de São Paulo. In: DAGNINO, E.; TATAGIBA, L.. (Org.). Democracia, Sociedade Civil $e$ Participação. Chapecó: Editora Argos, 2007.

FERREIRA, S. C. M. (2009). "Os atores do trabalho associativo: continuidades e descontinuidades da ação social”. In: CABANES, R. (org.). São Paulo, la ville d'en-bas. Paris, L’Harmattan (no prelo).

FIX, Mariana. Parceiros da Exclusão. São Paulo: Boitempo Editorial, 2001.

FOUCAULT, Michel. Vigiar e punir - nascimento da prisão. Petrópolis: Vozes, 1997.

FRANCO, Maria Sylvia de Carvalho. Homens Livres na Ordem Escravocrata. $3^{\mathrm{a}}$ Edição. São Paulo: Kairós, 1983

FURTADO, Celso. Formação econômica do Brasil. São Paulo: Editora Nacional, 1995.

GEORGES, Isabel; RIZEK, C. S. . A periferia dos direitos. 2008. (Apresentação de Trabalho/Congresso). Mimeo.

GOFFMAN, Erving. A representação do Eu na vida cotidiana. Rio de Janeiro: Vozes, 2006.

HABERMAS, Jürgen. Mudança Estrutural da Esfera Pública. Rio de Janeiro: Tempo Brasileiro, 1984.

HAUMONT, Bernard et MOREL, Alain. La societé des voisins. Partager u habitat collectif. Paris: Éditions de la Maison des sciences de 1’homme, 2005.

KOWARICK, Lucio. A espoliação urbana. Rio de Janeiro: Paz e Terra, 1979. 
LEFEBVRE, Henri. O direito à cidade. São Paulo: Ed. Morais, 1991.

Mapa da Exclusão/ Inclusão Social. NEPSAS. Núcleo de Estudos e Pesquisas sobre $\begin{array}{llllll}\text { Seguridade } & \text { e } & \text { Assistência } & \text { Social }\end{array}$ http://www.dpi.inpe.br/geopro/exclusao/oficinas/metodologia_mapa.pdf

LEME, Maria C. Silva. Revisão do Plano de Avenidas. Tese de Doutorado FAU-USP, 1990.

MAGNAVITA, Luiz Arnaldo Souza. COHAB-SP 1965-1990 - processos construtivos. Análise de uma questão sem resposta: habitação social. Dissertação de mestrado. EESC-USP, 1994.

MARICATO, Ermínia (org). A produção capitalista da Casa (e da Cidade) no Brasil Industrial. São Paulo: Alfa Omega, 1979.

MARICATO, Erminia. Indústria da Construção e Política Habitacional. Tese de Doutorado. FAU - USP, 1984.

MARICATO, Ermínia. Sociedade: A cidade é um grande negócio. Teoria e Debate em 1988. on line. http://www2.fpa.org.br/portal/modules/news/article.php?storyid=321

MARICATO, Ermínia. Metrópole na periferia do capitalismo: ilegalidade, desigualdade e violência. São Paulo: Hucitec, 1996.

MARQUES, Eduardo \& TORRES, Haroldo (org). São Paulo. Segregação, pobreza e desigualdades sociais. São Paulo: Editora Senac, 2005.

MELO, Marcus André B. C. Melo. Classe, burocracia e intermediação de interesses na formação da política de habitação. Espaço e Debates. № 24, 1988.

MIAGUSKO, Edson. Movimentos de moradia e sem teto em São Paulo: experiência no contexto do desmanche. Tese de doutorado em sociologia. FFLCH-USP, 2008 
NAKANO, Anderson Kazuo. 4 COHABs na zona leste de São Paulo: território, poder e segregação. Dissertação de Mestrado. FAU- USP; São Paulo. 2002

OLIVEIRA, Francisco. Os direitos do antivalor. A economia política da hegemonia imperfeita. São Paulo: Vozes, 1988.

OLIVEIRA, Francisco de. Crítica à Razão Dualista - O Ornitorrinco. São Paulo: Boitempo. 2003

OLIVEIRA, F.\& RIZEK, C.S. A Era da Indeterminação. São Paulo: Editora Boitempo, 2007.

PAOLI, Maria Célia. O mundo do indistinto: sobre gestão, violência e política. In OLIVEIRA, F.\& RIZEK, C.S. A Era da Indeterminação. São Paulo: Editora Boitempo, 2007.

PAULANI, Leda. Brasil delivery. Servidão financeira e estado de emergência econômico. São Paulo: Boitempo, 2008.

PRADO Jr, Caio. Formação do Brasil contemporâneo. São Paulo: Brasiliense, 1999.

PULHEZ, Magaly Marquez. Espaços de favela, fronteiras do ofício. História e experiências contemporâneas de arquitetos em assessorias de urbanização. Dissertação de Mestrado. EESC-USP, 2007.

RANCIÈRE, Jacques. O desentendimento. São Paulo: Editora 34, 1996.

RECAMÁN, Luiz . Forma sem Utopia. In: Adrian Forty; Elisabetta Andreolli. (Org.). Arquitetura Moderna Brasileira. Londres: Phaidon, 2004. Versão na internet: http://www.la2.com.br/textos/forma\%20sem\%20utopia.pdf 
RIZEK, C. S. . Cidade, Trabalho, Política. In: Cibele Saliba Rizek; Wagner de Melo Romão. (Org.). Francisco de Oliveira. A tarefa da crítica. Belo Horizonte: Editora da UFMG, 2006.

RIZEK, Cibele Saliba. Comunidades e pobreza urbana: do protagonismo à gestão. Mimeo.

RIZEK, C. S. ; BARROS, J. S. ; BERGAMIN, Marta de Aguiar . A política de produção habitacional por mutirões auto gestionários: construindo algumas questões. ANAIS do X ENA, Belo Horizonte, v. 1, n. 1.

ROLNIK, Raquel. Cada um no seu lugar! São Paulo no início da industrialização: geografia e poder. Dissertação de mestrado. FAU-USP, 1981.

ROLNIK, Raquel. A cidade e a lei - legislação, política urbana e territórios na cidade de São Paulo. São Paulo: FAPESP- Studio Nobel, 1997.

ROLNIK, Raquel. Reestruturação urbana da metrópole paulistana. Análise de territórios em transição. Relatório de pesquisa. PUC-Campinas/FAPESP. 2000.

ROLNIK, Raquel. São Paulo. São Paulo: Publifolha, 2001.

SADER, Eder. Quando novos personagens entram em cena. Rio de Janeiro: Paz e Terra, 1988.

SANTOS ,Wanderley Guilherme dos. Cidadania e justiça. Rio de Janeiro: Campus. 1979

SARTI, Cyntia Andersen. A família como espelho, um estudo sobre a moral dos pobres. São Paulo: Cortez Editora, 2005.

SCHWARZ, Roberto. As idéias fora do lugar. In: Ao vencedor as batatas. São Paulo: Duas Cidades, 1992. 
SILVA, Maria da Graça Plenamente. A "irregularidade" na produção de conjuntos habitacionais de interesse social: o caso da COHAB-SP. Dissertação de mestrado. São Paulo: FAUUSP, 2004.

SILVA, Ricardo Dias. Habitação mínima na primeira metade do século XX. 2006. http://www.nomads.usp.br/site/SAP5846/mono_ricardo_dias.pdf

SIMONI, Lucia Noemia. "O arruamento de terras e o processo de formação urbana do município de São Paulo de 1840 - 1930”. São Paulo: Tese de doutorado. FAU, 2002.

SINGER, Paul. "O uso do solo urbano na economia capitalista". In: MARICATO, Ermínia (org.). A produção capitalista da casa (e da cidade). São Paulo: Editora alphaomega, 1982 .

SLOMIANSKI, Adriana Paula. Cidade Tiradentes: a abordagem do poder público na construção da cidade; conjuntos habitacionais de interesse social da COHAB-SP (1965/1999), São Paulo: Tese de doutoramento. FAU - USP. 2002.

SOUZA, Mônica Virginia de. Colonizando a Periferia: zona Leste da cidade de São Paulo. Dissertação de Mestrado EESC/USP. 2003.

TELLES, Vera da Silva. Cidadania inexistente: incivilidade e pobreza. Um estudo sobre trabalhadores urbanos de São Paulo. Tese de doutorado. FFLCH- USP. 1992.

TELLES, Vera da Silva. Espaço Público e Espaço Privado: Notas sobre o pensamento de Hannah Arendt. In TELLES, Vera da Silva. Direitos Sociais: afinal do que se trata. Belo Horizonte: Editora UFMG, 1999.

TELLES, Vera da Silva. Trabalho e formas de vida. in Pobreza e cidadania. São Paulo: Editora 34, 2001.

TELLES, Vera da Silva. Em colaboração com CABANES, Robert. Cidade, política e cidadania: um estudo sobre as reconfigurações urbanas e novas regulações sociais. Projeto Integrado de Pesquisa. CNPQ 2001-2003 Relatório Final. São Paulo. Julho de 2003. 
TELLES, Vera da Silva \& Cabanes, Robert. (orgs.) Nas tramas da cidade. Trajetórias Urbanas e seus Territórios. São Paulo: Humanitas, 2006.

TELLES, Vera da Silva. Transitando na linha de sombra, tecendo as tramas da cidade (anotações inconclusa de uma pesquisa). in OLIVEIRA, F.\& RIZEK, C.S. A Era da Indeterminação. São Paulo: Editora Boitempo, 2007.

VALLADARES, Licia do Prado. A invenção da favela: do mito de origem à favela. Rio de Janeiro: Editora FGV, 2005.

VILLAÇA, Flávio. Espaço intra-urbano no Brasil. São Paulo: Studio Nobel/ Fapesp/ Lincoln Institut, 2001.

WEBER, Max. A ética protestante e o espírito do capitalismo. Lisboa: Ed. Presença, 1990.

WIEVIORKA, Micle. Violência hoje. Ciência e Saúde Coletiva, número 11. 2007. 
ANEXO 
Celetistas Admitidos (1), por Escolaridade, segundo Subprefeituras e Distritos Município de São Paulo

$2004(2)$

\begin{tabular}{|c|c|c|c|c|c|}
\hline $\begin{array}{l}\text { Subprefeituras e } \\
\text { Distritos }\end{array}$ & $\begin{array}{c}\text { Fundamental } \\
\text { Incompleto (3) }\end{array}$ & $\begin{array}{l}\text { Fundamental } \\
\text { Completo (4) }\end{array}$ & $\begin{array}{c}\text { Médio } \\
\text { Completo } \\
(5)\end{array}$ & $\begin{array}{l}\text { Superior } \\
\text { Completo }\end{array}$ & Total \\
\hline \multicolumn{6}{|l|}{ MUNICÍPIO DE SÃO } \\
\hline PAULO & 60.712 & 78.154 & 124.569 & 34.395 & 297.830 \\
\hline Aricanduva & 1.334 & 2.161 & 2.038 & 249 & 5.782 \\
\hline Aricanduva & 358 & 599 & 580 & 47 & 1.584 \\
\hline Carrão & 414 & 677 & 606 & 93 & 1.790 \\
\hline Vila Formosa & 562 & 885 & 852 & 109 & 2.408 \\
\hline Butantã & 3.219 & 2.984 & 4.169 & 1.358 & 11.730 \\
\hline Butantã & 982 & 702 & 1.181 & 408 & 3.273 \\
\hline Morumbi & 953 & 381 & 592 & 291 & 2.217 \\
\hline Raposo Tavares & 236 & 390 & 460 & 51 & 1.137 \\
\hline Rio Pequeno & 469 & 828 & 1.378 & 424 & 3.099 \\
\hline Vila Sônia & 579 & 683 & 558 & 184 & 2.004 \\
\hline Campo Limpo & 857 & 1.440 & 2.045 & 558 & 4.900 \\
\hline Campo Limpo & 374 & 623 & 900 & 261 & 2.158 \\
\hline Capão Redondo & 250 & 359 & 371 & 100 & 1.080 \\
\hline Vila Andrade & 233 & 458 & 774 & 197 & 1.662 \\
\hline \multicolumn{6}{|l|}{ Casa } \\
\hline Verde/Cachoeirinha & 1.491 & 1.963 & 3.385 & 649 & 7.488 \\
\hline Casa Verde & 584 & 705 & 1.109 & 198 & 2.596 \\
\hline Limão & 549 & 836 & 971 & 203 & 2.559 \\
\hline Nova Cachoeirinha & 358 & 422 & 1.305 & 248 & 2.333 \\
\hline Cidade Ademar & 610 & 849 & 1.061 & 159 & 2.679 \\
\hline Cidade Ademar & 517 & 722 & 906 & 116 & 2.261 \\
\hline Pedreira & 93 & 127 & 155 & 43 & 418 \\
\hline Cidade Tiradentes & 84 & 183 & 125 & 38 & 430 \\
\hline Cidade Tiradentes & 84 & 183 & 125 & 38 & 430 \\
\hline Ermelino Matarazzo & 449 & 821 & 1.456 & 505 & 3.231 \\
\hline Ermelino Matarazzo & 281 & 541 & 1.181 & 449 & 2.452 \\
\hline Ponte Rasa & 168 & 280 & 275 & 56 & 779 \\
\hline Freguesia/Brasilândia & 774 & 903 & 869 & 194 & 2.740 \\
\hline Brasilândia & 396 & 398 & 318 & 57 & 1.169 \\
\hline Freguesia do ó & 378 & 505 & 551 & 137 & 1.571 \\
\hline Guainases & 280 & 738 & 861 & 162 & 2.041 \\
\hline Guaianases & 86 & 173 & 206 & 26 & 491 \\
\hline Lajeado & 194 & 565 & 655 & 136 & 1.550 \\
\hline
\end{tabular}




\begin{tabular}{|c|c|c|c|c|c|}
\hline Ipiranga & 2.120 & 3.324 & 4.562 & 1.425 & 11.431 \\
\hline Cursino & 706 & 777 & 1.411 & 439 & 3.333 \\
\hline Ipiranga & 819 & 1.584 & 2.215 & 686 & 5.304 \\
\hline Sacomã & 595 & 963 & 936 & 300 & 2.794 \\
\hline Itaim Paulista & 943 & 654 & 489 & 68 & 2.154 \\
\hline Itaim Paulista & 847 & 432 & 317 & 37 & 1.633 \\
\hline Vila Curuçá & 96 & 222 & 172 & 31 & 521 \\
\hline Itaquera & 1.078 & 1.386 & 1.505 & 326 & 4.295 \\
\hline Cidade Líder & 200 & 273 & 281 & 24 & 778 \\
\hline Itaquera & 436 & 520 & 499 & 110 & 1.565 \\
\hline José Bonifácio & 82 & 185 & 243 & 32 & 542 \\
\hline Parque do Carmo & 360 & 408 & 482 & 160 & 1.410 \\
\hline Jabaquara & 3.408 & 2.023 & 2.867 & 1.378 & 9.676 \\
\hline Jabaquara & 3.408 & 2.023 & 2.867 & 1.378 & 9.676 \\
\hline Lapa & 4.324 & 6.702 & 10.529 & 2.410 & 23.965 \\
\hline Barra Funda & 960 & 1.248 & 2.369 & 530 & 5.107 \\
\hline Jaguara & 730 & 762 & 940 & 127 & 2.559 \\
\hline Jaguaré & 443 & 783 & 878 & 309 & 2.413 \\
\hline Lapa & 1.012 & 2.028 & 3.595 & 752 & 7.387 \\
\hline Perdizes & 631 & 909 & 1.425 & 438 & 3.403 \\
\hline Vila Leopoldina & 548 & 972 & 1.322 & 254 & 3.096 \\
\hline M'Boi Mirim & 1.197 & 1.027 & 1.635 & 602 & 4.461 \\
\hline Jardim Ângela & 406 & 427 & 384 & 83 & 1.300 \\
\hline São Luís & 791 & 600 & 1.251 & 519 & 3.161 \\
\hline Mooca & 3.465 & 6.129 & 7.148 & 1.259 & 18.001 \\
\hline Água Rasa & 460 & 1.010 & 1.050 & 138 & 2.658 \\
\hline Belém & 508 & 791 & 1.100 & 356 & 2.755 \\
\hline Brás & 1.025 & 1.713 & 1.786 & 155 & 4.679 \\
\hline Moóca & 571 & 879 & 1.076 & 252 & 2.778 \\
\hline Pari & 283 & 509 & 503 & 41 & 1.336 \\
\hline Tatuapé & 618 & 1.227 & 1.633 & 317 & 3.795 \\
\hline Parelheiros & 210 & 303 & 520 & 300 & 1.333 \\
\hline Marsilac & 63 & 176 & 169 & 46 & 454 \\
\hline Parelheiros & 147 & 127 & 351 & 254 & 879 \\
\hline Penha & 1.487 & 2.388 & 2.797 & 525 & 7.197 \\
\hline Artur Alvim & 106 & 267 & 178 & 29 & 580 \\
\hline Cangaíba & 376 & 683 & 952 & 214 & 2.225 \\
\hline Penha & 528 & 806 & 1.084 & 133 & 2.551 \\
\hline Vila Matilde & 477 & 632 & 583 & 149 & 1.841 \\
\hline Perus & 168 & 216 & 309 & 65 & 758 \\
\hline Anhanguera & 21 & 37 & 93 & 21 & 172 \\
\hline Perus & 147 & 179 & 216 & 44 & 586 \\
\hline Pinheiros & 6.419 & 6.977 & 14.492 & 5.352 & 33.240 \\
\hline$\underset{\gamma 1}{\text { Alto de Pinheiros }}$ & 363 & 272 & 334 & 189 & 1.158 \\
\hline
\end{tabular}




\begin{tabular}{|c|c|c|c|c|c|}
\hline Itaim Bibi & 2.757 & 3.270 & 8.040 & 3.137 & 17.204 \\
\hline Jardim Paulista & 916 & 1.542 & 3.104 & 1.119 & 6.681 \\
\hline Pinheiros & 2.383 & 1.893 & 3.014 & 907 & 8.197 \\
\hline Pirituba & 1.320 & 1.991 & 2.627 & 813 & 6.751 \\
\hline Jaraguá & 148 & 244 & 213 & 55 & 660 \\
\hline Pirituba & 788 & 1.060 & 1.312 & 375 & 3.535 \\
\hline São Domingos & 384 & 687 & 1.102 & 383 & 2.556 \\
\hline Santana/Tucuruvi & 2.116 & 2.497 & 3.388 & 694 & 8.695 \\
\hline Mandaqui & 423 & 536 & 792 & 143 & 1.894 \\
\hline Santana & 1.449 & 1.679 & 2.296 & 464 & 5.888 \\
\hline Tucuruvi & 244 & 282 & 300 & 87 & 913 \\
\hline Santo Amaro & 3.392 & 4.891 & 7.561 & 2.834 & 18.678 \\
\hline Campo Belo & 842 & 869 & 1.103 & 315 & 3.129 \\
\hline Campo Grande & 271 & 810 & 1.283 & 422 & 2.786 \\
\hline Santo Amaro & 2.279 & 3.212 & 5.175 & 2.097 & 12.763 \\
\hline São Mateus & 517 & 1.268 & 1.559 & 191 & 3.535 \\
\hline Iguatemi & 59 & 165 & 111 & 6 & 341 \\
\hline São Mateus & 336 & 789 & 1.037 & 120 & 2.282 \\
\hline São Rafael & 122 & 314 & 411 & 65 & 912 \\
\hline São Miguel & 765 & 1.018 & 1.087 & 254 & 3.124 \\
\hline Jardim Helena & 493 & 355 & 338 & 117 & 1.303 \\
\hline São Miguel & 142 & 399 & 429 & 36 & 1.006 \\
\hline Vila Jacuí & 130 & 264 & 320 & 101 & 815 \\
\hline Sé & 7.240 & 9.636 & 24.102 & 6.437 & 47.415 \\
\hline Bela Vista & 944 & 1.542 & 5.489 & 1.736 & 9.711 \\
\hline Bom Retiro & 1.032 & 1.753 & 2.007 & 343 & 5.135 \\
\hline Cambuci & 564 & 688 & 1.073 & 290 & 2.615 \\
\hline Consolacão & 465 & 943 & 1.657 & 973 & 4.038 \\
\hline Liberdade & 579 & 537 & 2.155 & 717 & 3.988 \\
\hline República & 1.574 & 1.589 & 6.773 & 1.009 & 10.945 \\
\hline Santa Cecília & 1.048 & 1.054 & 1.908 & 619 & 4.629 \\
\hline Sé & 1.034 & 1.530 & 3.040 & 750 & 6.354 \\
\hline Socorro & 1.605 & 2.158 & 2.738 & 552 & 7.053 \\
\hline Cidade Dutra & 450 & 627 & 1.053 & 281 & 2.411 \\
\hline Grajaú & 426 & 573 & 596 & 82 & 1.677 \\
\hline Socorro & 729 & 958 & 1.089 & 189 & 2.965 \\
\hline Tremembé/Jaçanã & 1.881 & 1.296 & 927 & 165 & 4.269 \\
\hline Jacanã & 454 & 443 & 496 & 112 & 1.505 \\
\hline Tremembé & 1.427 & 853 & 431 & 53 & 2.764 \\
\hline \multicolumn{6}{|l|}{ Vila Maria/Vila } \\
\hline Guilherme & 1.868 & 3.435 & 4.293 & 1.086 & 10.682 \\
\hline Vila Maria & 936 & 1.977 & 2.180 & 565 & 5.658 \\
\hline Vila Guilherme & 620 & 1.042 & 1.710 & 436 & 3.808 \\
\hline Vila Medeiros & 312 & 416 & 403 & 85 & 1.216 \\
\hline Vila Mariana & 4.944 & 4.851 & 11.077 & 3.412 & 24.284 \\
\hline
\end{tabular}




\begin{tabular}{lrrrrr} 
Moema & 1.467 & 1.537 & 3.196 & 720 & 6.920 \\
Saúde & 1.152 & 1.488 & 3.106 & 1.182 & 6.928 \\
Vila Mariana & 2.325 & 1.826 & 4.775 & 1.510 & 10.436 \\
Vila & & & & & \\
Prudente/Sapopemba & 1.147 & 1.942 & 2.348 & 375 & 5.812 \\
São Lucas & 322 & 526 & 603 & 91 & 1.542 \\
Sapopemba & 427 & 546 & 640 & 153 & 1.766 \\
Vila Prudente & 398 & 870 & 1.105 & 131 & 2.504 \\
\hline
\end{tabular}

Fonte: Ministério do Trabalho. Caged; Fundação Seade.

(1) Referem-se somente aos contratos de trabalho regidos pela Consolidação das Leis do Trabalho - CLT.

(2) Dados referentes ao período de janeiro a abril de 2004.

(3) Inclui analfabetos.

(4) Inclui ensino médio incompleto.

(5) Inclui ensino superior incompleto.

TABELA 1: CELETISTAS ADMITIDOS EM 2004 POR DISTRITO

Emprego Formal (1), por Sexo, segundo Subprefeituras e Distritos

Município de São Paulo

$2002(2)$

\begin{tabular}{lr|r|r}
\hline \multicolumn{1}{c|}{ Subprefeituras e Distritos } & Homens & Mulheres & \multicolumn{1}{c}{ Total } \\
\hline & & & \\
MUNICíPIO DE SÃO PAULO & 1.797 .542 & 1.467 .251 & 3.264 .793 \\
& & & \\
Aricanduva & 25.971 & 13.583 & 39.554 \\
Aricanduva & 8.097 & 3.996 & 12.093 \\
Carrão & 8.587 & 4.204 & 12.791 \\
Vila Formosa & 9.287 & 5.383 & 14.670 \\
& & & \\
Butantã & 57.324 & 34.209 & 91.533 \\
Butantã & 16.708 & 9.605 & 26.313 \\
Morumbi & 10.051 & 5.869 & 15.920 \\
Raposo Tavares & 6.876 & 3.078 & 9.954 \\
Rio Pequeno & 14.993 & 10.535 & 25.528 \\
Vila Sônia & 8.696 & 5.122 & 13.818 \\
& & & \\
Campo Limpo & 21.301 & 13.526 & 34.827 \\
Campo Limpo & 8.984 & 5.654 & 14.638 \\
Capão Redondo & 3.920 & 2.630 & 6.550 \\
Vila Andrade & 8.397 & 5.242 & 13.639 \\
& & & \\
Casa Verde/Cachoeirinha & 35.133 & 17.284 & 52.417 \\
Casa Verde & 13.248 & 5.871 & 19.119 \\
\end{tabular}




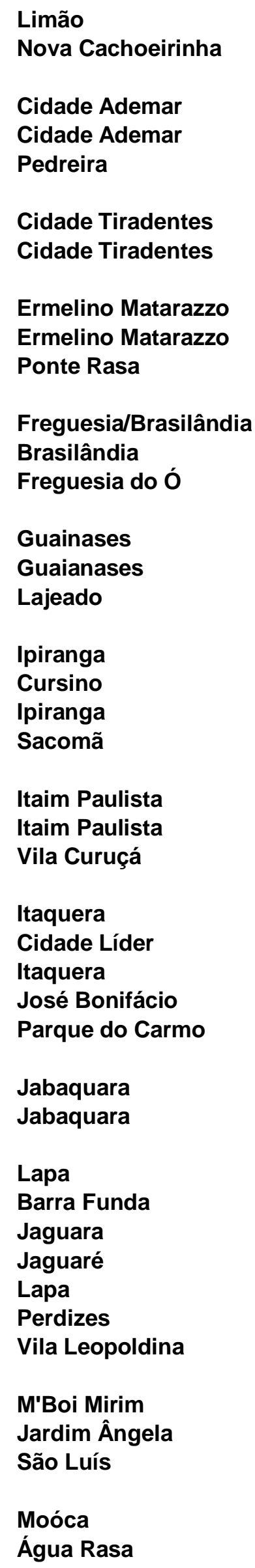

$\begin{array}{rrr}12.108 & 5.649 & 17.757 \\ 9.777 & 5.764 & 15.541 \\ & & \\ 12.042 & 6.106 & 18.148 \\ 10.032 & 5.173 & 15.205 \\ 2.010 & 933 & 2.943 \\ & & \\ 5.308 & 887 & 6.195 \\ 5.308 & 887 & 6.195\end{array}$

$\begin{array}{lll}62.283 & 87.366 & 149.649\end{array}$

$\begin{array}{lll}51.383 & 84.338 & 135.721\end{array}$

$\begin{array}{lll}10.900 & 3.028 & 13.928\end{array}$

$\begin{array}{lll}13.714 & 7.487 & 21.201\end{array}$

$\begin{array}{llr}5.550 & 2.876 & 8.426\end{array}$

$\begin{array}{lll}8.164 & 4.611 & 12.775\end{array}$

$\begin{array}{lll}9.941 & 5.776 & 15.717\end{array}$

$\begin{array}{lll}3.164 & 1.482 & 4.646\end{array}$

$\begin{array}{lll}6.777 & 4.294 & 11.071\end{array}$

$\begin{array}{lll}61.523 & 38.229 & 99.752\end{array}$

$\begin{array}{lll}15.383 & 13.448 & 28.831\end{array}$

$\begin{array}{lll}28.309 & 17.527 & 45.836\end{array}$

$\begin{array}{lll}17.831 & 7.254 & 25.085\end{array}$

$\begin{array}{lll}6.786 & 3.491 & 10.277\end{array}$

$\begin{array}{lll}4.522 & 2.265 & 6.787\end{array}$

$\begin{array}{lll}2.264 & 1.226 & 3.490\end{array}$

$\begin{array}{lll}27.375 & 14.626 & 42.001\end{array}$

$\begin{array}{lll}3.906 & 1.861 & 5.767\end{array}$

$\begin{array}{lll}9.906 & 4.252 & 14.158\end{array}$

$\begin{array}{lll}3.081 & 1.062 & 4.143\end{array}$

$\begin{array}{lll}10.482 & 7.451 & 17.933\end{array}$

$\begin{array}{lll}46.456 & 21.082 & 67.538\end{array}$

$\begin{array}{lll}46.456 & 21.082 & 67.538\end{array}$

$\begin{array}{lll}126.280 & 71.491 & 197.771\end{array}$

$\begin{array}{lll}25.877 & 13.886 & 39.763\end{array}$

$\begin{array}{lll}10.653 & 2.991 & 13.644\end{array}$

$\begin{array}{lll}15.780 & 11.622 & 27.402\end{array}$

$\begin{array}{lll}35.294 & 22.414 & 57.708\end{array}$

$\begin{array}{lrr}17.872 & 12.801 & 30.673\end{array}$

$\begin{array}{lll}20.804 & 7.777 & 28.581\end{array}$

$24.043 \quad 12.589 \quad 36.632$

$\begin{array}{lll}7.045 & 2.598 & 9.643\end{array}$

$\begin{array}{lll}16.998 & 9.991 & 26.989\end{array}$

$\begin{array}{lll}92.801 & 64.344 & 157.145\end{array}$

$\begin{array}{lll}11.263 & 7.360 & 18.623\end{array}$ 


\begin{tabular}{|c|c|c|c|}
\hline Belém & 19.965 & 13.417 & 33.382 \\
\hline Brás & 19.200 & 17.432 & 36.632 \\
\hline Moóca & 17.419 & 8.372 & 25.791 \\
\hline Pari & 5.913 & 5.144 & 11.057 \\
\hline Tatuapé & 19.041 & 12.619 & 31.660 \\
\hline Parelheiros & 9.053 & 7.455 & 16.508 \\
\hline Marsilac & 3.919 & 3.203 & 7.122 \\
\hline Parelheiros & 5.134 & 4.252 & 9.386 \\
\hline Penha & 38.302 & 21.234 & 59.536 \\
\hline Artur Alvim & 2.027 & 1.650 & 3.677 \\
\hline Cangaíba & 15.257 & 5.881 & 21.138 \\
\hline Penha & 12.458 & 8.987 & 21.445 \\
\hline Vila Matilde & 8.560 & 4.716 & 13.276 \\
\hline Perus & 4.027 & 2.067 & 6.094 \\
\hline Anhanguera & 1.390 & 503 & 1.893 \\
\hline Perus & 2.637 & 1.564 & 4.201 \\
\hline Pinheiros & 145.052 & 104.781 & 249.833 \\
\hline Alto de Pinheiros & 5.313 & 3.837 & 9.150 \\
\hline Itaim Bibi & 67.965 & 45.440 & 113.405 \\
\hline Jardim Paulista & 36.248 & 31.511 & 67.759 \\
\hline Pinheiros & 35.526 & 23.993 & 59.519 \\
\hline Pirituba & 45.738 & 22.624 & 68.362 \\
\hline Jaraguá & 7.142 & 2.131 & 9.273 \\
\hline Pirituba & 18.408 & 10.556 & 28.964 \\
\hline São Domingos & 20.188 & 9.937 & 30.125 \\
\hline Santana/Tucuruvi & 39.883 & 30.882 & 70.765 \\
\hline Mandaqui & 9.338 & 7.296 & 16.634 \\
\hline Santana & 25.367 & 19.730 & 45.097 \\
\hline Tucuruvi & 5.178 & 3.856 & 9.034 \\
\hline Santo Amaro & 186.101 & 60.070 & 246.171 \\
\hline Campo Belo & 17.056 & 9.392 & 26.448 \\
\hline Campo Grande & 15.073 & 8.649 & 23.722 \\
\hline Santo Amaro & 153.972 & 42.029 & 196.001 \\
\hline São Mateus & 18.705 & 12.441 & 31.146 \\
\hline Iguatemi & 3.716 & 775 & 4.491 \\
\hline São Mateus & 9.291 & 6.628 & 15.919 \\
\hline São Rafael & 5.698 & 5.038 & 10.736 \\
\hline São Miguel & 15.370 & 8.619 & 23.989 \\
\hline Jardim Helena & 7.676 & 3.174 & 10.850 \\
\hline São Miguel & 3.925 & 2.814 & 6.739 \\
\hline Vila Jacuí & 3.769 & 2.631 & 6.400 \\
\hline Sé & 287.985 & 278.478 & 566.463 \\
\hline Bela Vista & 94.479 & 142.891 & 237.370 \\
\hline $\begin{array}{l}\text { Bom Retiro } \\
85\end{array}$ & 30.389 & 22.859 & 53.248 \\
\hline
\end{tabular}




\begin{tabular}{|c|c|c|c|}
\hline Cambuci & 25.716 & 14.976 & 40.692 \\
\hline Consolacão & 24.700 & 14.407 & 39.107 \\
\hline Liberdade & 17.288 & 11.279 & 28.567 \\
\hline República & 35.594 & 27.648 & 63.242 \\
\hline Santa Cecília & 26.284 & 16.193 & 42.477 \\
\hline Sé & 33.535 & 28.225 & 61.760 \\
\hline Socorro & 31.670 & 18.833 & 50.503 \\
\hline Cidade Dutra & 10.860 & 7.992 & 18.852 \\
\hline Grajaú & 5.198 & 2.997 & 8.195 \\
\hline Socorro & 15.612 & 7.844 & 23.456 \\
\hline Tremembé/Jaçanã & 12.564 & 7.714 & 20.278 \\
\hline Jacanã & 8.753 & 5.768 & 14.521 \\
\hline Tremembé & 3.811 & 1.946 & 5.757 \\
\hline Vila Maria/Vila Guilherme & 66.836 & 36.732 & 103.568 \\
\hline Vila Maria & 38.147 & 23.759 & 61.906 \\
\hline Vila Guilherme & 22.670 & 10.313 & 32.983 \\
\hline Vila Medeiros & 6.019 & 2.660 & 8.679 \\
\hline Vila Mariana & 234.975 & 425.135 & 660.110 \\
\hline Moema & 26.758 & 22.621 & 49.379 \\
\hline Saúde & 170.539 & 370.074 & 540.613 \\
\hline Vila Mariana & 37.678 & 32.440 & 70.118 \\
\hline Vila Prudente/Sapopemba & 33.000 & 18.110 & 51.110 \\
\hline São Lucas & 7.242 & 4.166 & 11.408 \\
\hline Sapopemba & 12.985 & 6.064 & 19.049 \\
\hline Vila Prudente & 12.773 & 7.880 & 20.653 \\
\hline \multicolumn{4}{|c|}{$\begin{array}{l}\text { Fonte: Ministério do Trabalho e Emprego - MTE. Relação Anual de Informações } \\
\text { Sociais - RAIS. 2002; } \\
\text { Fundação Seade. } \\
\text { (1) Emprego formal refere-se ao total de vínculos empregatícios composto por } \\
\text { contratos } \\
\text { regidos pela CLT (trabalhador urbano/rural vinculado a empregador pessoa } \\
\text { jurídica/física, por tempo determinado/indeterminado; trabalhador avulso, } \\
\text { trabalhador temporário e menor aprendiz), pelo Regime Jurídico Único e Militar } \\
\text { (federal, estadual e municipal) e pela Legislação Especial (servidor público não } \\
\text { efetivo). Deve-se mencionar que um único trabalhador pode ter mais de um vínculo } \\
\text { empregatício. } \\
\text { (2) Dados referentes a } 31 \text { de dezembro de 2002. } \\
\text { TABELA 2: EMPREGO FORMAL POR DISTRITO EM } 2002 \text {. }\end{array}$} \\
\hline
\end{tabular}


Distribuição do Emprego Formal (1), por Setor de Atividade, segundo Subprefeituras e Distritos -

Total por Localidade

Município de São Paulo

$2002(2)$

Em porcentagem

\begin{tabular}{|c|c|c|c|c|c|}
\hline Subprefeituras e Distritos & Indústria & $\begin{array}{c}\text { Construção } \\
\text { Civil }\end{array}$ & Comércio & Serviços & Total (3) \\
\hline MUNICÍPIO DE SÃO PAULO & 14,5 & 4,0 & 16,1 & 65,4 & 100,0 \\
\hline Aricanduva & 31,0 & 4,4 & 31,6 & 33,0 & 100,0 \\
\hline Aricanduva & 46,4 & 1,9 & 31,3 & 20,4 & 100,0 \\
\hline Carrão & 33,1 & 7,6 & 30,1 & 29,3 & 100,0 \\
\hline Vila Formosa & 16,4 & 3,8 & 33,2 & 46,6 & 100,0 \\
\hline Butantã & 13,7 & 9,4 & 19,8 & 56,8 & 100,0 \\
\hline Butantã & 8,5 & 16,4 & 18,6 & 56,4 & 100,0 \\
\hline Morumbi & 5,5 & 5,9 & 17,9 & 70,6 & 100,0 \\
\hline Raposo Tavares & 28,7 & 11,1 & 26,1 & 34,1 & 100,0 \\
\hline Rio Pequeno & 12,9 & 4,9 & 13,9 & 67,9 & 100,0 \\
\hline Vila Sônia & 24,1 & 7,4 & 30,6 & 37,7 & 100,0 \\
\hline Campo Limpo & 23,0 & 4,7 & 25,6 & 46,6 & 100,0 \\
\hline Campo Limpo & 29,7 & 5,0 & 19,6 & 45,7 & 100,0 \\
\hline Capão Redondo & 20,4 & 7,3 & 31,1 & 41,3 & 100,0 \\
\hline Vila Andrade & 17,0 & 3,3 & 29,5 & 50,2 & 100,0 \\
\hline Casa Verde/Cachoeirinha & 30,1 & 4,9 & 23,1 & 41,7 & 100,0 \\
\hline Casa Verde & 33,3 & 4,3 & 27,0 & 35,4 & 100,0 \\
\hline Limão & 34,0 & 4,2 & 21,3 & 40,3 & 100,0 \\
\hline Nova Cachoeirinha & 21,9 & 6,3 & 20,5 & 51,3 & 100,0 \\
\hline Cidade Ademar & 25,8 & 8,1 & 33,8 & 32,4 & 100,0 \\
\hline Cidade Ademar & 25,0 & 8,4 & 34,2 & 32,4 & 100,0 \\
\hline Pedreira & 29,9 & 6,4 & 31,4 & 32,3 & 100,0 \\
\hline Cidade Tiradentes & 12,0 & 2,5 & 20,5 & 65,0 & 100,0 \\
\hline Cidade Tiradentes & 12,0 & 2,5 & 20,5 & 65,0 & 100,0 \\
\hline Ermelino Matarazzo & 5,0 & 0,4 & 5,2 & 89,4 & 100,0 \\
\hline Ermelino Matarazzo & 2,8 & 0,3 & 4,3 & 92,7 & 100,0 \\
\hline Ponte Rasa & 26,8 & 1,5 & 14,8 & 57,0 & 100,0 \\
\hline Freguesia/Brasilândia & 32,0 & 4,6 & 30,6 & 32,8 & 100,0 \\
\hline Brasilândia & 32,9 & 3,8 & 34,4 & 28,9 & 100,0 \\
\hline Freguesia do ó & 31,4 & 5,1 & 28,2 & 35,3 & 100,0 \\
\hline Guainases & 16,0 & 8,5 & 42,6 & 32,6 & 100,0 \\
\hline Guaianases & 36,4 & 1,6 & 38,5 & 23,6 & 100,0 \\
\hline Lajeado & 7,4 & 11,4 & 44,3 & 36,4 & 100,0 \\
\hline Ipiranga & 30,8 & 3,6 & 20,9 & 44,6 & 100,0 \\
\hline Cursino & 12,5 & 5,0 & 20,4 & 62,1 & 100,0 \\
\hline
\end{tabular}




\begin{tabular}{|c|c|c|c|c|c|}
\hline Ipiranga & 34,1 & 3,6 & 21,0 & 41,2 & 100,0 \\
\hline Sacomã & 45,8 & 2,2 & 21,3 & 30,7 & 100,0 \\
\hline Itaim Paulista & 14,6 & 7,5 & 43,0 & 34,8 & 100,0 \\
\hline Itaim Paulista & 14,3 & 9,1 & 40,1 & 36,4 & 100,0 \\
\hline Vila Curuçá & 15,2 & 4,4 & 48,6 & 31,7 & 100,0 \\
\hline Itaquera & 29,0 & 4,5 & 18,7 & 47,6 & 100,0 \\
\hline Cidade Líder & 28,2 & 15,3 & 35,8 & 20,7 & 100,0 \\
\hline Itaquera & 8,4 & 3,0 & 19,2 & 69,3 & 100,0 \\
\hline José Bonifácio & 58,7 & 1,5 & 20,9 & 18,7 & 100,0 \\
\hline Parque do Carmo & 38,7 & 3,0 & 12,3 & 45,7 & 100,0 \\
\hline Jabaquara & 12,7 & 11,7 & 14,9 & 60,7 & 100,0 \\
\hline Jabaquara & 12,7 & 11,7 & 14,9 & 60,7 & 100,0 \\
\hline Lapa & 20,6 & 4,1 & 22,4 & 52,6 & 100,0 \\
\hline Barra Funda & 30,8 & 3,2 & 15,2 & 50,8 & 100,0 \\
\hline Jaguara & 24,8 & 5,9 & 17,8 & 51,6 & 100,0 \\
\hline Jaguaré & 17,0 & 1,5 & 15,4 & 65,9 & 100,0 \\
\hline Lapa & 19,4 & 4,9 & 25,4 & 50,3 & 100,0 \\
\hline Perdizes & 7,6 & 6,9 & 21,9 & 63,5 & 100,0 \\
\hline Vila Leopoldina & 24,2 & 2,5 & 36,0 & 35,9 & 100,0 \\
\hline M'Boi Mirim & 21,1 & 6,1 & 25,0 & 47,8 & 100,0 \\
\hline Jardim Ângela & 19,0 & 9,6 & 30,2 & 41,1 & 100,0 \\
\hline São Luís & 21,9 & 4,9 & 23,1 & 50,2 & 100,0 \\
\hline Moóca & 31,7 & 2,4 & 26,3 & 39,6 & 100,0 \\
\hline Água Rasa & 36,3 & 1,7 & 34,0 & 28,0 & 100,0 \\
\hline Belém & 21,8 & 2,2 & 13,2 & 62,7 & 100,0 \\
\hline Brás & 41,2 & 1,2 & 34,5 & 23,1 & 100,0 \\
\hline Moóca & 40,6 & 2,9 & 20,4 & 36,0 & 100,0 \\
\hline Pari & 41,7 & 0,2 & 34,2 & 23,8 & 100,0 \\
\hline Tatuapé & 17,6 & 4,6 & 28,0 & 49,8 & 100,0 \\
\hline Parelheiros & 19,2 & 7,5 & 20,2 & 52,9 & 100,0 \\
\hline Marsilac & 23,1 & 7,0 & 17,8 & 52,1 & 100,0 \\
\hline Parelheiros & 16,3 & 7,8 & 22,0 & 53,5 & 100,0 \\
\hline Penha & 35,1 & 2,8 & 30,0 & 32,1 & 100,0 \\
\hline Artur Alvim & 15,9 & 3,5 & 47,0 & 33,6 & 100,0 \\
\hline Cangaíba & 46,9 & 1,6 & 26,3 & 25,2 & 100,0 \\
\hline Penha & 26,3 & 1,4 & 32,9 & 39,4 & 100,0 \\
\hline Vila Matilde & 36,1 & 6,6 & 26,4 & 30,9 & 100,0 \\
\hline Perus & 17,7 & 10,7 & 31,6 & 39,9 & 100,0 \\
\hline Anhanguera & 34,3 & 14,9 & 16,1 & 34,6 & 100,0 \\
\hline Perus & 10,2 & 8,9 & 38,6 & 42,3 & 100,0 \\
\hline Pinheiros & 9,8 & 8,9 & 17,5 & 63,6 & 100,0 \\
\hline Alto de Pinheiros & 7,1 & 7,0 & 24,7 & 60,9 & 100,0 \\
\hline Itaim Bibi & 14,2 & 7,4 & 15,3 & 63,0 & 100,0 \\
\hline Jardim Paulista & 3,8 & 4,2 & 17,3 & 74,6 & $188^{100,0}$ \\
\hline
\end{tabular}




\begin{tabular}{|c|c|c|c|c|c|}
\hline Pinheiros & 8,5 & 17,6 & 20,8 & 52,7 & 100,0 \\
\hline Pirituba & 32,3 & 4,9 & 18,1 & 44,7 & 100,0 \\
\hline Jaraguá & 50,7 & 4,1 & 13,9 & 31,3 & 100,0 \\
\hline Pirituba & 10,2 & 8,3 & 21,6 & 59,9 & 100,0 \\
\hline São Domingos & 47,8 & 1,9 & 16,1 & 34,2 & 100,0 \\
\hline Santana/Tucuruvi & 9,9 & 3,2 & 23,6 & 63,2 & 100,0 \\
\hline Mandaqui & 15,6 & 3,3 & 27,9 & 52,9 & 100,0 \\
\hline Santana & 6,8 & 3,1 & 20,5 & 69,4 & 100,0 \\
\hline Tucuruvi & 14,3 & 3,4 & 31,0 & 51,2 & 100,0 \\
\hline Santo Amaro & 13,0 & 3,5 & 12,2 & 71,2 & 100,0 \\
\hline Campo Belo & 6,9 & 12,3 & 24,6 & 56,2 & 100,0 \\
\hline Campo Grande & 45,3 & 3,6 & 15,2 & 35,8 & 100,0 \\
\hline Santo Amaro & 9,8 & 2,4 & 10,2 & 77,6 & 100,0 \\
\hline São Mateus & 21,4 & 2,3 & 33,9 & 42,3 & 100,0 \\
\hline Iguatemi & 21,3 & 0,9 & 17,3 & 60,2 & 100,0 \\
\hline São Mateus & 31,2 & 1,6 & 44,0 & 23,2 & 100,0 \\
\hline São Rafael & 7,0 & 3,9 & 25,9 & 63,3 & 100,0 \\
\hline São Miguel & 27,7 & 4,0 & 31,1 & 37,2 & 100,0 \\
\hline Jardim Helena & 43,2 & 3,5 & 11,5 & 41,9 & 100,0 \\
\hline São Miguel & 17,2 & 2,9 & 46,9 & 32,9 & 100,0 \\
\hline Vila Jacuí & 12,5 & 5,9 & 47,7 & 33,9 & 100,0 \\
\hline Sé & 10,8 & 2,2 & 12,7 & 74,3 & 100,0 \\
\hline Bela Vista & 1,6 & 0,9 & 3,6 & 93,8 & 100,0 \\
\hline Bom Retiro & 40,5 & 3,0 & 14,0 & 42,5 & 100,0 \\
\hline Cambuci & 24,3 & 3,7 & 15,5 & 56,5 & 100,0 \\
\hline Consolacão & 12,4 & 7,3 & 10,3 & 69,9 & 100,0 \\
\hline Liberdade & 19,7 & 3,3 & 14,2 & 62,7 & 100,0 \\
\hline República & 7,3 & 2,4 & 21,5 & 68,5 & 100,0 \\
\hline Santa Cecília & 15,1 & 2,6 & 24,7 & 57,5 & 100,0 \\
\hline Sé & 7,1 & 1,2 & 27,8 & 63,8 & 100,0 \\
\hline Socorro & 32,8 & 4,2 & 30,2 & 32,7 & 100,0 \\
\hline Cidade Dutra & 22,1 & 1,7 & 34,0 & 42,1 & 100,0 \\
\hline Grajaú & 14,0 & 11,6 & 39,1 & 34,9 & 100,0 \\
\hline Socorro & 48,0 & 3,7 & 24,0 & 24,2 & 100,0 \\
\hline Tremembé/Jaçanã & 30,0 & 2,6 & 27,3 & 40,1 & 100,0 \\
\hline Jacanã & 33,7 & 1,6 & 25,3 & 39,3 & 100,0 \\
\hline Tremembé & 20,4 & 5,0 & 32,4 & 42,1 & 100,0 \\
\hline Vila Maria/Vila Guilherme & 15,5 & 9,4 & 23,0 & 52,1 & 100,0 \\
\hline Vila Maria & 16,8 & 2,0 & 17,0 & 64,2 & 100,0 \\
\hline Vila Guilherme & 11,3 & 23,6 & 32,1 & 32,9 & 100,0 \\
\hline Vila Medeiros & 22,6 & 8,2 & 31,3 & 37,9 & 100,0 \\
\hline Vila Mariana & 1,7 & 2,3 & 4,7 & 91,2 & 100,0 \\
\hline Moema & 6,6 & 7,2 & 26,9 & 59,2 & 100,0 \\
\hline $\begin{array}{l}\text { Saúde } \\
89\end{array}$ & 0,8 & 1,3 & 1,7 & 96,3 & 100,0 \\
\hline
\end{tabular}




\begin{tabular}{lrrrrr} 
Vila Mariana & 5,4 & 7,0 & 12,5 & 75,0 & 100,0 \\
& & & & & \\
Vila Prudente/Sapopemba & 29,5 & 3,6 & 28,5 & 38,2 & 100,0 \\
São Lucas & 38,4 & 2,8 & 34,1 & 24,7 & 100,0 \\
Sapopemba & 16,3 & 4,5 & 24,5 & 54,4 & 100,0 \\
Vila Prudente & 36,9 & 3,3 & 29,0 & 30,8 & 100,0 \\
\hline
\end{tabular}

Fonte: Ministério do Trabalho e Emprego - MTE. Relação Anual de Informações Sociais RAIS. 2002; Fundação Seade.

(1) Emprego formal refere-se ao total de vínculos empregatícios composto por contratos regidos pela CLT (trabalhador urbano/rural vinculado a empregador pessoa jurídica/física, por tempo determinado/indeterminado; trabalhador avulso, trabalhador temporário e menor aprendiz), pelo Regime Jurídico Único e Militar (federal, estadual e municipal) e pela Legislação Especial (servidor público não efetivo). Deve-se mencionar que um único trabalhador pode ter mais de um vínculo empregatício.

(2) Dados referentes a 31 de dezembro de 2002.

(3) Inclui o setor Agropecuário.

TABELA 3: EMPREGOS POR SETOR E DISTRITOS EM 2002

Em porcentagem

\begin{tabular}{|c|c|c|c|c|c|c|}
\hline \multirow[b]{2}{*}{ Distritos } & \multicolumn{6}{|c|}{ Faixas de Renda (em Salários Mínimos) } \\
\hline & $\begin{array}{c}\text { Menos de } 2 \\
\text { SM }\end{array}$ & $\begin{array}{c}\text { De } 2 \text { a } \\
\text { Menos de } 5 \\
\text { SM }\end{array}$ & $\begin{array}{c}\text { De } 5 \text { a } \\
\text { Menos de } \\
10 \mathrm{SM}\end{array}$ & $\begin{array}{l}\text { De } 10 \text { a } \\
\text { Menos de } \\
15 \text { SM }\end{array}$ & $\begin{array}{c}\text { De } 15 \text { a } \\
\text { Menos de } \\
25 \text { SM }\end{array}$ & $\begin{array}{c}\text { De } 25 \text { SM e } \\
\text { Mais }\end{array}$ \\
\hline \multicolumn{7}{|l|}{ MUNICÍPIO DE SÃO } \\
\hline PAULO & 13,30 & 24,39 & 25,97 & 11,29 & 10,98 & 14,06 \\
\hline Água Rasa & 8,33 & 17,31 & 26,60 & 14,01 & 15,96 & 17,78 \\
\hline Alto de Pinheiros & 3,47 & 5,44 & 12,22 & 9,30 & 15,85 & 53,72 \\
\hline Anhanguera & 18,29 & 34,93 & 31,91 & 8,90 & 3,99 & 1,98 \\
\hline Aricanduva & 11,64 & 24,95 & 28,47 & 13,72 & 13,33 & 7,88 \\
\hline Artur Alvim & 12,03 & 23,22 & 31,51 & 15,87 & 12,60 & 4,77 \\
\hline Barra Funda & 6,66 & 11,23 & 23,98 & 12,87 & 14,22 & 31,04 \\
\hline Bela Vista & 4,81 & 12,59 & 23,28 & 15,33 & 17,46 & 26,53 \\
\hline Belém & 7,77 & 17,08 & 24,51 & 14,79 & 16,11 & 19,74 \\
\hline Bom Retiro & 10,20 & 20,04 & 24,70 & 14,70 & 15,57 & 14,79 \\
\hline Brás & 10,27 & 19,34 & 31,06 & 15,23 & 11,64 & 12,46 \\
\hline Brasilândia & 19,87 & 34,23 & 28,27 & 9,15 & 5,99 & 2,49 \\
\hline Butantã & 4,93 & 10,60 & 16,23 & 12,10 & 18,25 & 37,88 \\
\hline Cachoeirinha & 15,74 & 29,57 & 28,54 & 11,17 & 9,35 & 5,62 \\
\hline Cambuci & 7,77 & 15,60 & 23,26 & 14,99 & 17,70 & 20,68 \\
\hline Campo Belo & 4,92 & 9,48 & 13,81 & 9,90 & 13,45 & 48,44 \\
\hline Campo Grande & 5,96 & 14,00 & 20,23 & 11,89 & 17,63 & 30,29 \\
\hline Campo Limpo & 16,07 & 28,25 & 28,71 & 11,26 & 9,96 & 5,76 \\
\hline Cangaíba & 12,05 & 27,17 & 30,24 & 12,56 & 11,56 & 6,42 \\
\hline Capão Redondo & 18,30 & 32,80 & 29,82 & 9,36 & 6,50 & 3,22 \\
\hline Carrão & 9,18 & 18,17 & 25,82 & 14,91 & 16,3590 & 15,58 \\
\hline
\end{tabular}




\begin{tabular}{|c|c|c|c|c|c|c|}
\hline Casa Verde & 8,51 & 19,05 & 28,32 & 13,74 & 14,49 & 15,90 \\
\hline Cidade Ademar & 16,73 & 28,46 & 28,84 & 10,73 & 8,66 & 6,58 \\
\hline Cidade Dutra & 15,30 & 27,10 & 29,26 & 12,03 & 9,64 & 6,67 \\
\hline Cidade Líder & 14,03 & 26,70 & 30,78 & 13,63 & 9,14 & 5,72 \\
\hline Cidade Tiradentes & 20,47 & 36,92 & 31,23 & 7,53 & 3,08 & 0,76 \\
\hline Consolação & 3,77 & 8,33 & 17,19 & 10,49 & 15,74 & 44,47 \\
\hline Cursino & 8,17 & 16,65 & 24,17 & 13,86 & 15,21 & 21,93 \\
\hline Ermelino Matarazzo & 15,73 & 31,16 & 28,99 & 11,12 & 9,04 & 3,97 \\
\hline Freguesia do Ó & 11,20 & 21,92 & 28,19 & 13,88 & 14,04 & 10,78 \\
\hline Grajaú & 22,92 & 35,87 & 28,21 & 7,55 & 4,08 & 1,38 \\
\hline Guaianazes & 19,76 & 35,70 & 29,17 & 8,62 & 5,19 & 1,56 \\
\hline Moema & 2,91 & 3,43 & 9,95 & 8,55 & 13,78 & 61,38 \\
\hline Iguatemi & 22,67 & 36,89 & 28,73 & 6,87 & 3,43 & 1,40 \\
\hline Ipiranga & 9,68 & 20,11 & 23,56 & 13,37 & 14,64 & 18,64 \\
\hline Itaim Bibi & 3,87 & 6,61 & 12,98 & 8,83 & 14,78 & 52,92 \\
\hline Itaim Paulista & 22,99 & 37,29 & 26,86 & 7,20 & 4,13 & 1,54 \\
\hline Itaquera & 17,50 & 29,22 & 29,28 & 11,11 & 8,62 & 4,28 \\
\hline Jabaquara & 10,27 & 20,27 & 24,48 & 13,51 & 13,56 & 17,91 \\
\hline Jaçanã & 12,37 & 25,74 & 28,58 & 12,99 & 12,29 & 8,02 \\
\hline Jaguara & 9,64 & 21,17 & 30,03 & 14,78 & 14,51 & 9,88 \\
\hline Jaguaré & 12,37 & 22,34 & 24,14 & 9,63 & 14,54 & 16,99 \\
\hline Jaraguá & 15,66 & 31,57 & 32,01 & 10,77 & 7,42 & 2,58 \\
\hline Jardim Ângela & 22,18 & 38,05 & 27,82 & 6,83 & 3,82 & 1,29 \\
\hline Jardim Helena & 25,07 & 36,35 & 25,61 & 7,25 & 4,19 & 1,53 \\
\hline Jardim Paulista & 2,43 & 4,04 & 11,97 & 9,17 & 16,61 & 55,78 \\
\hline Jardim São Luís & 16,16 & 31,76 & 30,08 & 10,26 & 7,85 & 3,89 \\
\hline José Bonifácio & 13,76 & 25,52 & 32,00 & 15,65 & 10,07 & 3,00 \\
\hline Lajeado & 24,67 & 38,67 & 25,80 & 6,66 & 3,07 & 1,13 \\
\hline Lapa & 4,89 & 11,86 & 20,15 & 12,25 & 17,97 & 32,87 \\
\hline Liberdade & 6,47 & 13,96 & 21,56 & 11,52 & 16,90 & 29,59 \\
\hline Limão & 11,30 & 24,80 & 25,49 & 14,25 & 13,54 & 10,62 \\
\hline Mandaqui & 6,73 & 15,36 & 24,64 & 15,25 & 17,32 & 20,70 \\
\hline Marsilac & 44,10 & 31,22 & 19,47 & 4,31 & 0,19 & 0,71 \\
\hline Moóca & 6,70 & 13,11 & 21,07 & 12,54 & 18,11 & 28,48 \\
\hline Morumbi & 4,00 & 9,05 & 10,76 & 5,67 & 9,95 & 60,58 \\
\hline Parelheiros & 26,06 & 38,16 & 25,79 & 6,15 & 2,83 & 1,01 \\
\hline Pari & 10,84 & 20,53 & 24,98 & 14,91 & 14,95 & 13,80 \\
\hline Parque do Carmo & 16,08 & 29,07 & 30,80 & 11,41 & 8,25 & 4,39 \\
\hline Pedreira & 21,24 & 32,70 & 28,57 & 8,86 & 5,60 & 3,03 \\
\hline Penha & 11,25 & 21,04 & 26,39 & 14,51 & 13,76 & 13,05 \\
\hline Perdizes & 2,70 & 5,45 & 12,84 & 10,72 & 17,47 & 50,83 \\
\hline Perus & 18,27 & 35,47 & 29,33 & 9,61 & 4,94 & 2,39 \\
\hline Pinheiros & 3,77 & 5,98 & 14,34 & 9,60 & 16,53 & 49,79 \\
\hline Pirituba & 11,94 & 23,63 & 27,39 & 13,39 & 13,55 & 10,09 \\
\hline Ponte Rasa & 11,81 & 23,99 & 30,66 & 13,89 & 12,35 & 7,30 \\
\hline Raposo Tavares & 12,73 & 27,95 & 29,05 & 12,50 & 10,54 & 7,24 \\
\hline República & 8,09 & 16,69 & 31,18 & 15,64 & 14,93 & 13,46 \\
\hline Rio Pequeno & 11,80 & 22,00 & 22,77 & 12,38 & 13,08 & 17,96 \\
\hline Sacomã & 12,16 & 23,27 & 28,38 & 12,81 & 12,92 & 10,47 \\
\hline Santa Cecília & 5,53 & 11,60 & 23,33 & 14,45 & 17,95 & 27,14 \\
\hline Santana & 4,90 & 9,79 & 19,97 & 14,06 & 18,15 & 33,13 \\
\hline Santo Amaro & 4,17 & 6,84 & 16,87 & 10,41 & 18,59 & 43,13 \\
\hline Sao Domingos & 9,94 & 23,88 & 26,83 & 12,95 & 12,93 & 13,46 \\
\hline $\begin{array}{l}\text { São Lucas } \\
91\end{array}$ & 11,43 & 22,31 & 28,44 & 14,50 & 13,85 & 9,46 \\
\hline
\end{tabular}




\begin{tabular}{lrrrrrr} 
São Mateus & 15,19 & 29,02 & 29,37 & 12,68 & 9,81 & 3,93 \\
São Miguel & 17,47 & 30,40 & 28,29 & 10,75 & 8,87 & 4,23 \\
São Rafael & 21,34 & 35,49 & 28,48 & 8,17 & 4,79 & 1,74 \\
Sapopemba & 18,08 & 31,19 & 30,19 & 10,75 & 6,79 & 3,00 \\
Saúde & 3,96 & 9,12 & 17,22 & 10,84 & 18,52 & 40,33 \\
Sé & 11,02 & 25,04 & 31,85 & 14,56 & 10,45 & 7,09 \\
Socorro & 8,65 & 13,72 & 24,01 & 12,82 & 17,58 & 23,22 \\
Tatuapé & 5,92 & 11,73 & 18,17 & 12,14 & 18,99 & 33,05 \\
Tremembé & 13,14 & 27,78 & 28,30 & 11,43 & 9,74 & 9,62 \\
Tucuruvi & 7,27 & 16,38 & 24,87 & 15,11 & 18,15 & 18,20 \\
Vila Andrade & 14,15 & 25,13 & 17,41 & 5,50 & 6,37 & 31,44 \\
Vila Curuça & 22,61 & 34,37 & 27,32 & 8,68 & 4,74 & 2,28 \\
Vila Formosa & 8,10 & 20,08 & 28,69 & 13,91 & 13,08 & 16,14 \\
Vila Guilherme & 8,79 & 18,24 & 27,99 & 15,52 & 14,95 & 14,51 \\
Vila Jacuí & 19,02 & 34,65 & 28,16 & 9,23 & 6,14 & 2,80 \\
Vila Leopoldina & 5,15 & 19,06 & 16,64 & 9,59 & 15,95 & 33,61 \\
Vila Maria & 12,26 & 27,16 & 29,32 & 12,11 & 10,93 & 8,22 \\
Vila Mariana & 2,87 & 7,03 & 13,69 & 9,90 & 17,47 & 49,05 \\
Vila Matilde & 10,26 & 22,29 & 28,47 & 14,83 & 14,01 & 10,16 \\
Vila Medeiros & 12,32 & 24,21 & 31,25 & 13,80 & 11,97 & 6,45 \\
Vila Prudente & 10,43 & 21,42 & 27,28 & 12,52 & 13,92 & 14,43 \\
Vila Sônia & 9,58 & 16,05 & 20,05 & 11,28 & 13,96 & 29,07 \\
\hline Fon & & & & & &
\end{tabular}

Fonte: IBGE; Fundação Seade.

Nota: Exluindo-se os domicílios cuja espécie é do tipo coletivo.

Salário mínimo de referência do Censo 2000: $R \$ 151,00$.

TABELA 4: FAIXA DE RENDA POR DISTRITO EM 2000. 